Ground-Water Hydrology and Subsurface Migration of Radionuclides at a Commercial Radioactive-Waste Burial Site, West Valley, Cattaraugus County, New York

U.S. GEOLOGICAL SURVEY PROFESSIONAL PAPER 1325 
Ground-Water Hydrology and Subsurface Migration of Radionuclides at a Commercial Radioactive-Waste Burial Site, West Valley, Cattaraugus County, New York

\author{
By DAVID E. PRUDIC
}

U.S. GEOLOGICAL SURVEY PROFESSIONAL PAPER 1325

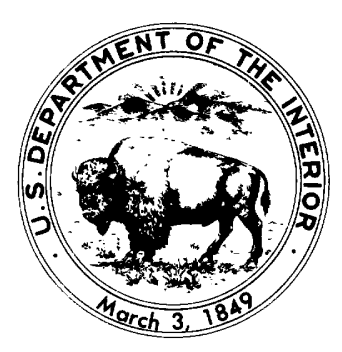

UNITED STATES GOVERNMENT PRINTING OFFICE, WASHINGTON : 1986 


\section{DEPARTMENT OF THE INTERIOR \\ DONALD PAUL HODEL, Secretary}

\section{U.S. GEOLOGICAL SURVEY}

Dallas L. Peck, Director

Library of Congress Cataloging-in-Publication Data

Prudic, David E.

Ground-water hydrology and subsurface migration of radionuclides at a commercial radioactive-waste burial site, West Valley, Cattaraugus County, New York.

(U.S. Geological Survey professional paper ; 1325)

Bibliography: p. 80

Supt. of Docs. no.: I 19.16:1325

1. Water, Underground-New York (State)-Cattaraugus County. 2. Ground-water flow-New York (State)-Cattaraugus County-Simulation methods. 3. Radioactive-waste disposal in the ground-New York (State)-Cattaraugus County. I. Title. II. Series: Geological Survey professional paper ; 1325.

\section{GB1025.N7P78 $1986 \quad 628.1^{\prime} 685 \quad 84-600197$}

For sale by the Books and Open-File Reports Section, U.S. Geological Survey, Federal Center, Box 25425, Denver, CO 80225 


\section{CONTENTS}

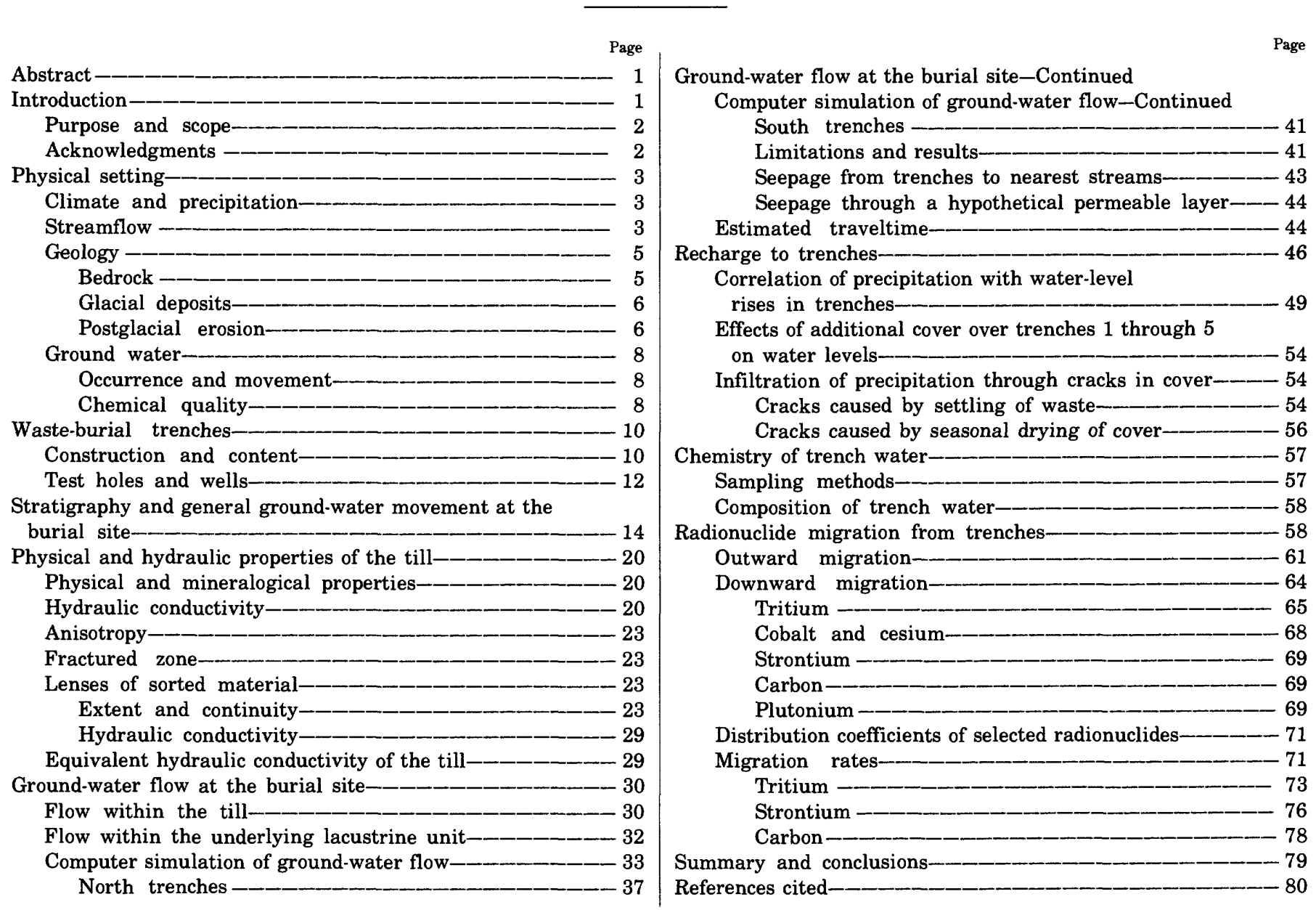

\section{ILLUSTRATIONS}

FIGURE 1. Map showing location of Western New York Nuclear Service Center, streams, and selected wells within Cattaraugus Creek basin

2. Map showing location of reprocessing center, waste-burial trenches, streams, wells, test holes, and geologic

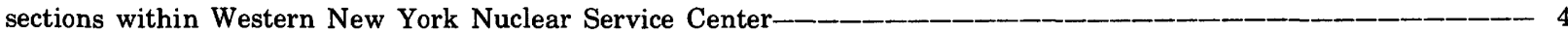

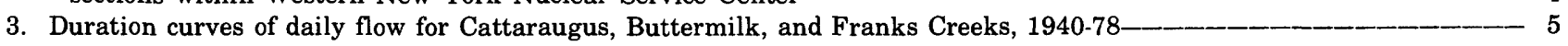

4. Graphs showing monthly distribution of average annual runoff, Cattaraugus Creek at Gowanda-__- 6

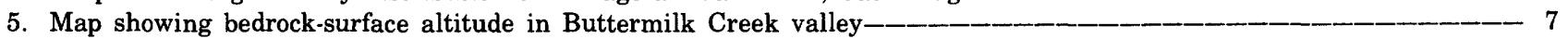

6. Vertical section showing typical ground-water flow patterns in the region near West Valley-______________ 8

7. Map showing locations of waste-burial trenches and nearby test holes and wells-_____-__-_-_-_-

8. Map showing surficial geology of burial site and vicinity-__

9. Geologic sections across and along Buttermilk Creek-_____-

10. Idealized cross section in vicinity of the burial site west of Buttermilk Creek showing inferred distribution of saturated and unsaturated material and general directions of ground-water flow-_-___-_- 19

11. Graph showing relation of hydraulic conductivity and volumetric soil-moisture content to soil-moisture tension--_-- - 23

12. Cross sections showing distribution of sorted material in till at waste-burial site__________

13. Vertical sections through trenches showing head distribution during February 1976_________________

14. Graphs showing water-level trend in piezometers, January 1976 through May 1978______________________

15. Map showing direction of ground-water flow in lacustrine sequence beneath the till, as determined from water levels in three piezometers 
FigURE 16. Vertical section C-C $^{\prime}$ through north trenches showing node arrangement, boundary conditions, relative hydraulic conductivity values, and relative infiltration rates used in best-fit simulation-___ _ _ 39

17. Vertical section $\mathbf{C}-\mathbf{C}^{\prime}$ through north trenches showing computer-simulated distribution of heads-_-____-_- 40

18. Graph showing comparison of computer-simulated water levels with observed water levels in piezometers D-1, D-2, and D2-1 during 8 months after pumpout of water from trench 5-_-_- - - _ - 41

19. Vertical section $D-D^{\prime}$ through south trenches-

20. Vertical section $E-E^{\prime}$ from trench 4 northward to

21. Vertical section D-D' through south trenches showing computer-simulated distribution

of head, and assuming trenches to be filled with water-_ Part of vertical section $D-\mathrm{D}^{\prime}$ from trench 8 eastward to Franks Creek showing computer-simulated

\section{.} ,

\section{.}

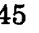
distribution of head, and assuming a permeable layer from trench to stream-

23. Graphs showing water-level trends in trenches, 1966-79_-_

24. Graphs showing water level in trench 5 in relation to precipitation-___

25. Graphs showing water level in trench 5 after pumpout of water in July and September 1976 and November 1977

26. Graphs showing water level in trenches 12 and 14 in relation to precipitation, March 1979 through January 1980

. Graphs showing water level in trench 5 after covers of trenches 1 through 5 were regraded in August 1978- - - - 55

28. Profiles showing changes in tritium concentrations with depth in test holes near the burial site-_-

29-30. Profiles of tritium concentrations:

29. In till at north end of trenches 2 and 3-_

30. Beneath selected trenches -

31. Sketches showing inferred trench geometry near test holes 4-3A and 4-4A-

32. Profiles showing comparison of observed tritium concentrations with those calculated from an analytical

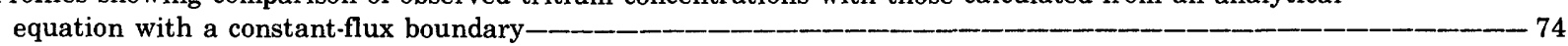

33. Profile showing predicted tritium concentrations beneath trench 5 after 10 and 100 years--_-_--_- - - - 76

34. Profiles showing comparison of observed and calculated ${ }^{90} \mathrm{Sr}$ concentrations beneath trench 8 in test hole 8.2B-- - - 77

35. Profile showing comparison of observed and calculated ${ }^{90} \mathrm{Sr}$ concentrations beneath trench 4 in test hole $4-4 \mathrm{~A}----78$

36. Profile showing predicted ${ }^{90} \mathrm{Sr}$ concentrations in till beneath trench 4 after 10,100 , and 500 years ___

\section{TABLES}

TABLE 1. Quality of ground water from wells in south-central part of Cattaraugus Creek basin--

3. Volume of waste containers in trenches 8 through 14

4. Stratigraphy of Quaternary sediments in central Buttermilk Creek valley_______________________________

5. Particle size of selected core samples____

6. Mineral composition of selected core samples-_____-

7. Results of slug tests for hydraulic conductivity at piezometers finished in unoxidized till_______

8. Results of laboratory tests for hydraulic conductivity of core samples from the unoxidized till-________

9. Results of slug tests for hydraulic conductivity at piezometers finished in lenses of sorted materials-_-__-_-

10. Heads observed in February 1976 and February 1978 compared with results of best-fitting computer simulations for isotropic and anisotropic conditions-_____ 38

11. Lowest 30-day and 60-day cumulative rainfall periods from May through October, 1968 through 1978, at Franklinville, New York-____________- 56

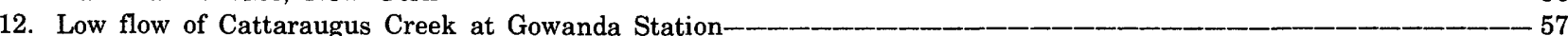

13. Changes in concentration of tritium and gross alpha and gross beta determinations in trenches 4,5 , and 8 with time

15. Chemical quality of water in trenches-_-__C_-

16. Concentration of selected radionuclides beneath trenches 4,5 , and 8 


\section{CONVERSION FACTORS AND ABBREVIATIONS}

The following factors may be used to convert the International System of Units (SI) in this report ${ }^{1}$ to inchpound units.

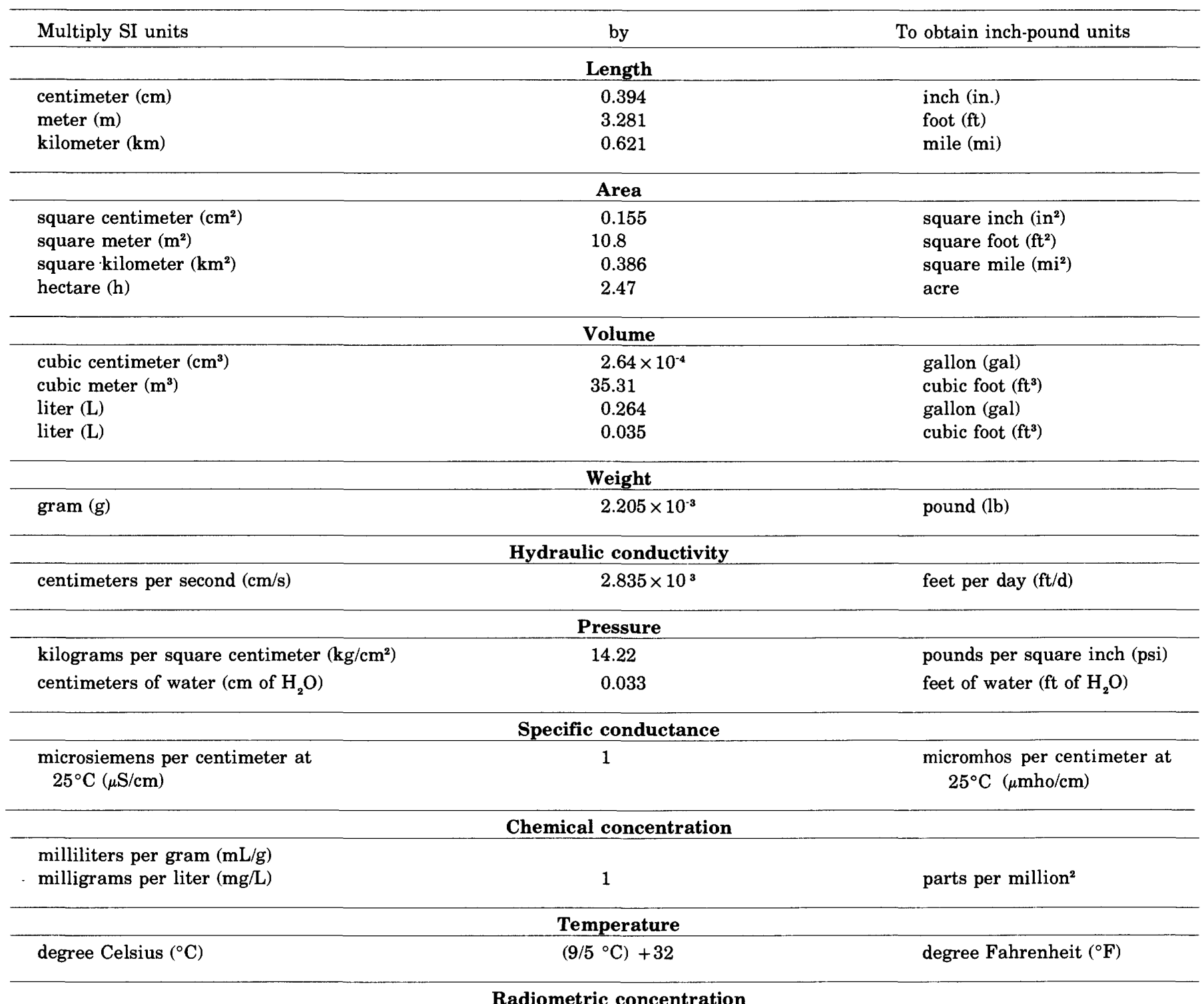

microcuries per millimeter $(\mu \mathrm{Ci} / \mathrm{mL})$

microcuries per gram $(\mu \mathrm{Ci} / \mathrm{g})$

\footnotetext{
${ }^{1}$ Topographic maps of this area have contour intervals of 10 feet; therefore illustrations incorporating these maps are scaled in conventional units. ${ }^{2}$ Milligrams per liter approximately equal parts per million when dissolved-solids concentration is less than about 7,000 milligrams per liter.
} 


\section{Notation for Selected Radionuclides}

\begin{tabular}{llc}
\hline Notation & \multicolumn{1}{c}{ Element } & Atomic weights \\
\hline${ }^{3} \mathrm{H}$ & Tritium (hydrogen) & 3 \\
$\mathrm{HTO}$ & $\begin{array}{l}\text { Tritium (hydrogen } \\
\text { in form of water) }\end{array}$ & 3 \\
& Carbon & 14 \\
${ }^{14} \mathrm{C}$ & Cobalt & 60 \\
${ }^{60} \mathrm{Co}$ & Potassium & 40 \\
${ }^{40} \mathrm{~K}$ & Sodium & 22 \\
${ }^{22} \mathrm{Na}$ & Strontium & 85 \\
${ }^{85} \mathrm{Sr}$ & Strontium & 90 \\
${ }^{90} \mathrm{Sr}$ & Barium & 133 \\
${ }^{133} \mathrm{Ba}$ & Cesium & 134 \\
${ }^{134} \mathrm{Cs}$ & Cesium & 137 \\
${ }^{137} \mathrm{Cs}$ & Americium & 241 \\
${ }^{241} \mathrm{Am}$ & Plutonium & 238 \\
${ }^{238} \mathrm{Pu}$ & Plutonium & 239,240 \\
${ }^{239,240} \mathrm{Pu}$ & &
\end{tabular}

\section{ALTITUDE DATUM}

The term "National Geodetic Vertical Datum of 1929" (NGVD of 1929) replaces the formerly used term "mean sea level" to describe the datum for altitude measurements. NGVD of 1929 is derived from a general adjustment of the firstorder leveling networks of both the United States and Canada. For convenience in this report, the datum is referred to as sea level. 


\title{
GROUND-WATER HYDROLOGY AND SUBSURFACE MIGRATION OF RADIONUCLIDES AT A COMMERCIAL RADIOACTIVE-WASTE BURIAL SITE, WEST VALLEY, CATTARAUGUS COUNTY, NEW YORK
}

\author{
By DAVId E. PRUdIC
}

\begin{abstract}
Low-level radioactive wastes were buried during 1963-75 in a series of trenches excavated in a fine-grained till. The till is about $28 \mathrm{~m}$ thick. Beneath the till is a lacustrine sequence that is unsaturated in the upper few meters but saturated in the lower several meters; the saturated part provides an avenue of slow lateral flow to nearby Buttermilk Creek. Fractures with oxidized and (or) reduced walls extend as much as $5 \mathrm{~m}$ below the pre-trench land surface. Simulation of ground-water flow in the till by a digital computer model suggests that the fractured till is 5 to 10 times more permeable than the underlying unfractured till and that the hydraulic conductivity of the unfractured till decreases by 15 to 30 percent with depth as a result of compaction by overburden. The direction of ground-water flow through the till is predominantly downward because the underlying lacustrine sequence acts as a drain to the till. The specific flux of water is estimated to be between 0.3 and $2.3 \mathrm{~cm} / \mathrm{yr}$; this is equivalent to an average linear (pore) velocity of 1 to $8 \mathrm{~cm} / \mathrm{yr}$, assuming a porosity of 30 percent.

All trenches contain water, and water levels in some have risen repeatedly and have required periodic pumpout. Computer simulations indicate that water seeping outward through the trench walls will not reach adjacent small streams as long as water in the trenches remains below the base of the covers. Deformed lenses of silt and sand constitute 7 percent of the till mass, but few extend more than a few meters laterally; simulations suggest that even an extensive lens would not conduct trench water to a nearby stream. If trench water should rise into the 2 to $4 \mathrm{~m}$ of reworked till covering the trenches and seep out, however, it could flow overland to streams.

Differences in the rates of water-level rise among the trenches are attributed to differences in hydraulic conductivity of the cover material. In trenches completed before 1970 , water began to rise after the dry summer of 1971, overflowed briefly from two trenches in 1975, and was periodically removed by pumping thereafter. In four of the seven trenches completed during $1970-75$, water levels rose noticeably after the dry summer 1978. The increase in water-level rise is attributed to desiccation cracks that intersected or enlarged previous cracks that had formed by settling of buried waste. Water-level trends in the trenches indicate that once cracks extend through the cover, they do not close completely, even during wet periods.

Peak tritium concentrations (generally $10^{-5}$ to $10^{-3} \mu \mathrm{Ci} / \mathrm{mL}$ ) in cores from test holes drilled near the trenches in 1976 were found within $3 \mathrm{~m}$ of land surface and are attributed to surface contamination from fallout or surface spills. Secondary peaks found at about 9
\end{abstract}

$m$ depth from cores of two test holes next to trench 5 suggest that outward migration may be as much as $3 \mathrm{~m}$. Other radionuclides were detected only near land surface or in reworked till that covers the trenches and nearby areas.

Tritium concentrations in cores collected from beneath trenches 4, 5, and 8 in November and December 1977 indicate that tritium migrated less than $3 \mathrm{~m}$ downward in the 7 to 11 years after the trenches were completed. Estimates of tritium migration calculated from a one-dimensional analytical equation indicate that the migration of tritium is controlled by molecular diffusion. On the basis of the assumption that the concentration of tritium remains constant in the trench water for 100 years, the maximum distance tritium might migrate is estimated to be between 10 and $14 \mathrm{~m}$ below the trench floor.

The one radionuclide besides tritium to have migrated close to $1 \mathrm{~m}$ is ${ }^{14} \mathrm{C}$. The other radionuclides have apparently migrated less than a meter, but the distance they have migrated has not been exactly defined. The time for detectable concentrations of ${ }^{14} \mathrm{C}$ to migrate through the $23 \mathrm{~m}$ of till is estimated to range from 1,500 to 20,000 years. No estimate was made as to the time required for a detectable concentration of ${ }^{14} \mathrm{C}$ to reach Buttermilk Creek by migrating through the lacustrine unit beneath the till. However, radionuclides are far less likely to reach the surface environment by subsurface migration than by saturation and overflow of the trenches, which can occur wherever substantial recharge enters through cracks in the cover. In addition, radionuclides can migrate as gases through the covers and open pipes in the trenches.

\section{INTRODUCTION}

A State-licensed landfill for commercial radioactive wastes is among the facilities at the Western New York Nuclear Service Center, which occupies $13.5 \mathrm{~km}^{2}$ in the northern part of Cattaraugus County, N.Y. (figs. 1 and 2). The site is in a sparsely populated region about 50 $\mathrm{km}$ south of Buffalo that is characterized by rounded hills of shale and siltstone that are capped with till and separated by valleys containing glacial deposits as much as $150 \mathrm{~m}$ thick.

In 1975, the U.S. Geological Survey began a study to determine which factors control the subsurface migra- 


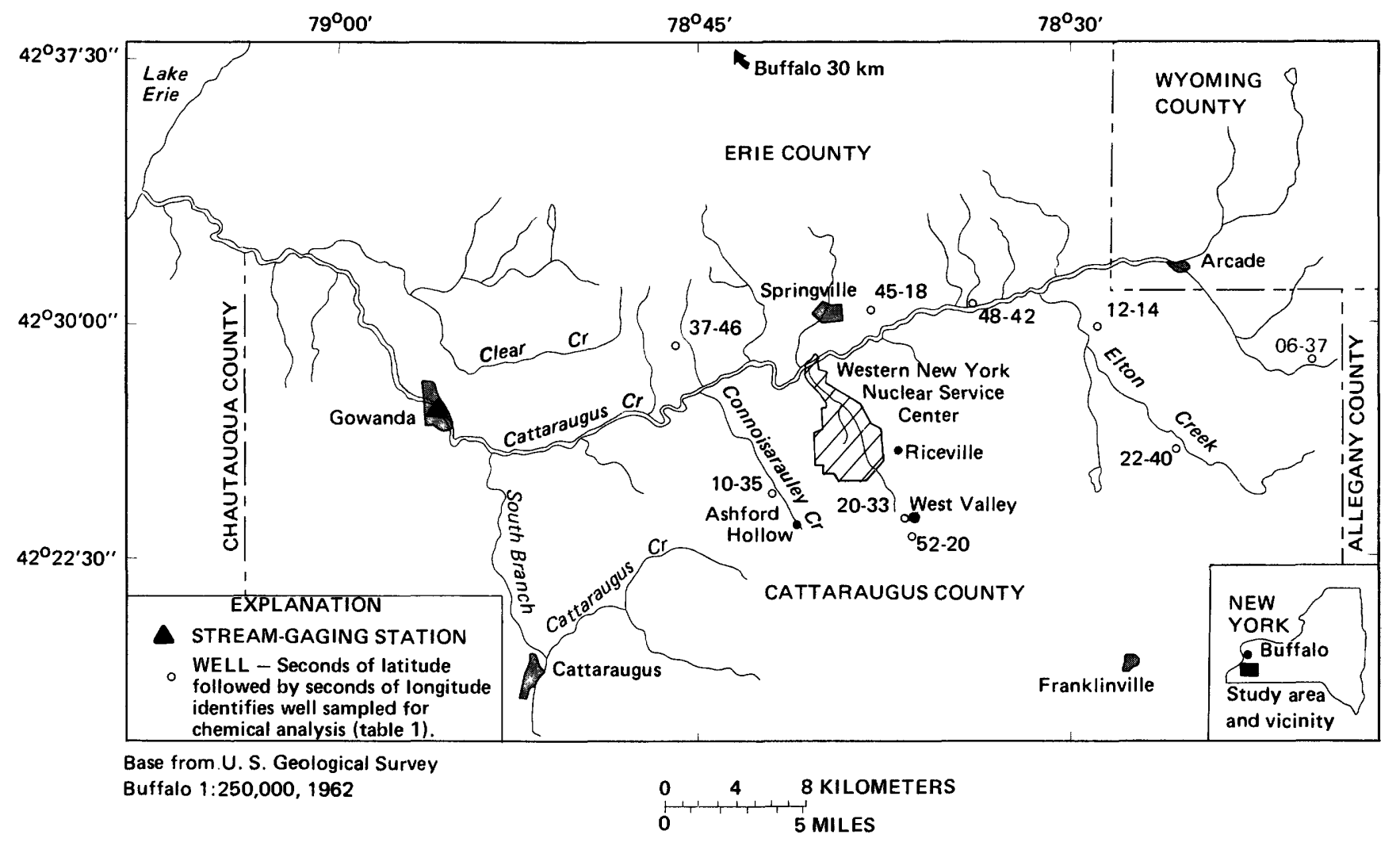

FIGURE 1.-Location of Western New York Nuclear Service Center, streams, and selected wells within Cattaraugus Creek basin.

tion of radionuclides at the site. The study was one of several being conducted by the Survey at nuclear-waste landfills across the Nation. At the same time, the New York State Geological Survey, as lead agency under contract with the U.S. Environmental Protection Agency and the Nuclear Regulatory Commission, assumed responsibility for evaluating all processes of radionuclide migration, including subsurface flow, at the site. Many elements of the two studies required the same information, and several were jointly planned and completed by the two Surveys. Examples of joint efforts include surficial geologic mapping of the site and vicinity (LaFleur, 1979), installation of water- and gas-sampling wells into the trenches (Prudic, 1978), and the collection of core samples from beneath the trench floors (Prudic, 1979a).

\section{PURPOSE AND SCOPE}

This report is a summary of the U.S. Geological Survey study at the burial site from 1975 through 1980 . The report has fourfold purpose. First, it describes the general geohydrologic setting in the vicinity of the burial site, including climate, streamflow, geology, ground-water movement, and ground-water quality. Sec- ond, it describes the history of the site, including the types of waste buried and the method of burying the wastes. Third, it describes in detail the ground-water hydrology and geology at the burial site, including the periodic rise of water within some of the trenches. Fourth, it evaluates the potential for subsurface migration of radionuclides from the trenches to land surface.

\section{ACKNOWLEDGMENTS}

Many people participated in this and related studies to evaluate the mechanisms by which radionuclides could migrate from the burial site; some results of their work are included in this report. Interpretations of the geology near the burial site were done chiefly by Robert G. LaFleur (Rensselaer Polytechnic Institute) and Allan D. Randall (U.S. Geological Survey). Allan Randall also designed most of the test holes and provided guidance for the study. Robert Fakundiny and Jeffrey Pferd (New York State Geological Survey) also contributed to the interpretation of the geology, mapped the extent of fractures near the trenches, and, along with James F. Davis (New York State Geological Survey), assisted in the design of test holes drilled 
beneath the trenches. Scott Keys (U.S. Geological Survey) interpreted the results of many geophysical logs designed to detect subsurface migration of radionuclides. Edwin P. Weeks (U.S. Geological Survey) assisted in the ground-water flow modeling and in evaluating the permeability of the trench covers. John Matuszek (New York State Department of Health, Radiological Sciences Laboratory) and A. J. Weiss (Brookhaven National Laboratory) designed techniques to collect and analyze samples for chemical and radionuclide content and interpreted the many results. Alan Lu (New York State Department of Health, Radiological Sciences Laboratory) wrote the analytic equation and computer program that was used to estimate the migration of radionuclides away from the trenches.

Chemical and radiochemical analyses of trench water and of core samples of the till were done at the New York State Department of Health, Radiological Sciences Laboratory, and at Brookhaven National Laboratory. Laboratory analyses of hydrologic properties of core samples were done at the Hydrologic Laboratory of the U.S. Geological Survey, Denver, Colo., except for the falling-head permeameter tests, which were performed by TerraTek, Inc., Salt Lake City, Utah, and for two particle-size analyses, which were performed by Dunn Geoscience Laboratory, Latham, N.Y.

Thanks are extended to Stephen Molello (New York State Geological Survey) and Robert Wozniak (New York State Department of Environmental Conservation) for assistance with fieldwork. Thanks also are extended to the following for granting access to the burial site: the New York State Department of Environmental Conservation, Bureau of Radiation, regulator of the site; the New York State Department of Energy Research and Development Authority, owner of the site, and Nuclear Fuels Services, Inc., the site operator. Nuclear Fuels Services personnel also helped in locating data, provided health-physics monitoring, and allowed access and use of their machine shop, storage facilities, and equipment.

\section{PHYSICAL SETTING}

The main facilities of the Western New York Service Center are about $6 \mathrm{~km}$ northwest of West Valley on the west side of Buttermilk Creek valley (figs. 1 and 2). The State-licensed burial site is about $500 \mathrm{~m}$ southeast of the main facilities and covers approximately 4 ha. Franks Creek, a tributary to Buttermilk Creek, drains the east, south, and southwest parts of the burial site; an unnamed tributary to Franks Creek drains the north and northwest parts.

\section{CLIMATE AND PRECIPITATION}

Climate at the burial site is humid continental (National Oceanic and Atmospheric Administration, 1978), dominated by the interplay of humid, warm air masses from the Gulf of Mexico and subtropical waters with dry, cold air from the northern interior of the continent.

Prevailing winds are from the west-southwesterly during warm months and northwesterly during winter. Wind speed normally is less than $15 \mathrm{~km} / \mathrm{h}$, but occasional strong winds from well-developed storm systems may cause property damage. Thunderstorms are common during summer and occur on about 30 days per year. Hail locally accompanies some thunderstorms but rarely causes extensive property damage or crop losses. Only three or four tornadoes are reported within New York each year; in July 1975, one caused localized property damage about $8 \mathrm{~km}$ north of the burial site.

Annual average air temperature at three stations within $25 \mathrm{~km}$ of the site is about $7^{\circ} \mathrm{C}$ (National Oceanic and Atmospheric Administration, 1978). Mean monthly temperatures range from $-6^{\circ} \mathrm{C}$ in January and February to $20^{\circ} \mathrm{C}$ in July. In general, the winters are long and cold. A temperature of $-26^{\circ} \mathrm{C}$ or lower can be expected at least once a winter, and a minimum temperature of $-18^{\circ} \mathrm{C}$ can be expected on about 15 days in most winters. Summers are short and cool, with daytime temperatures in the range of $24^{\circ} \mathrm{C}$ to $29^{\circ} \mathrm{C}$. Temperatures of $32^{\circ} \mathrm{C}$ or higher occur only two or three days a year. Air temperature during summer frequently drops close to $4^{\circ} \mathrm{C}$ and may approach freezing during June and the latter half of August. The number of freezefree days ranges from 100 to 120 .

Average annual precipitation near West Valley is about $100 \mathrm{~cm}$. Monthly precipitation generally averages from a low of $7 \mathrm{~cm}$ in winter to a high of $9 \mathrm{~cm}$ in spring, early summer, and late fall. Distinctly dry or wet periods seldom repeat each year. Precipitation in winter normally is in the form of snow. The area is affected by heavy snow storms off Lake Erie, $40 \mathrm{~km}$ to the west and northwest. These "lake-effect" storms are most frequent in November and December, before the lake surface freezes. Individual storms often generate more than 30 $\mathrm{cm}$ of snow, and accumulations of $125 \mathrm{~cm}$ or more within two consecutive months are common (National Oceanic and Atmospheric Administration, 1978). A continuous snow cover can be expected from mid-December to midMarch; maximum depths usually occur in February.

\section{STREAMFLOW}

Runoff from the burial site flows into Lake Erie via Franks Creek, Buttermilk Creek, and Cattaraugus 


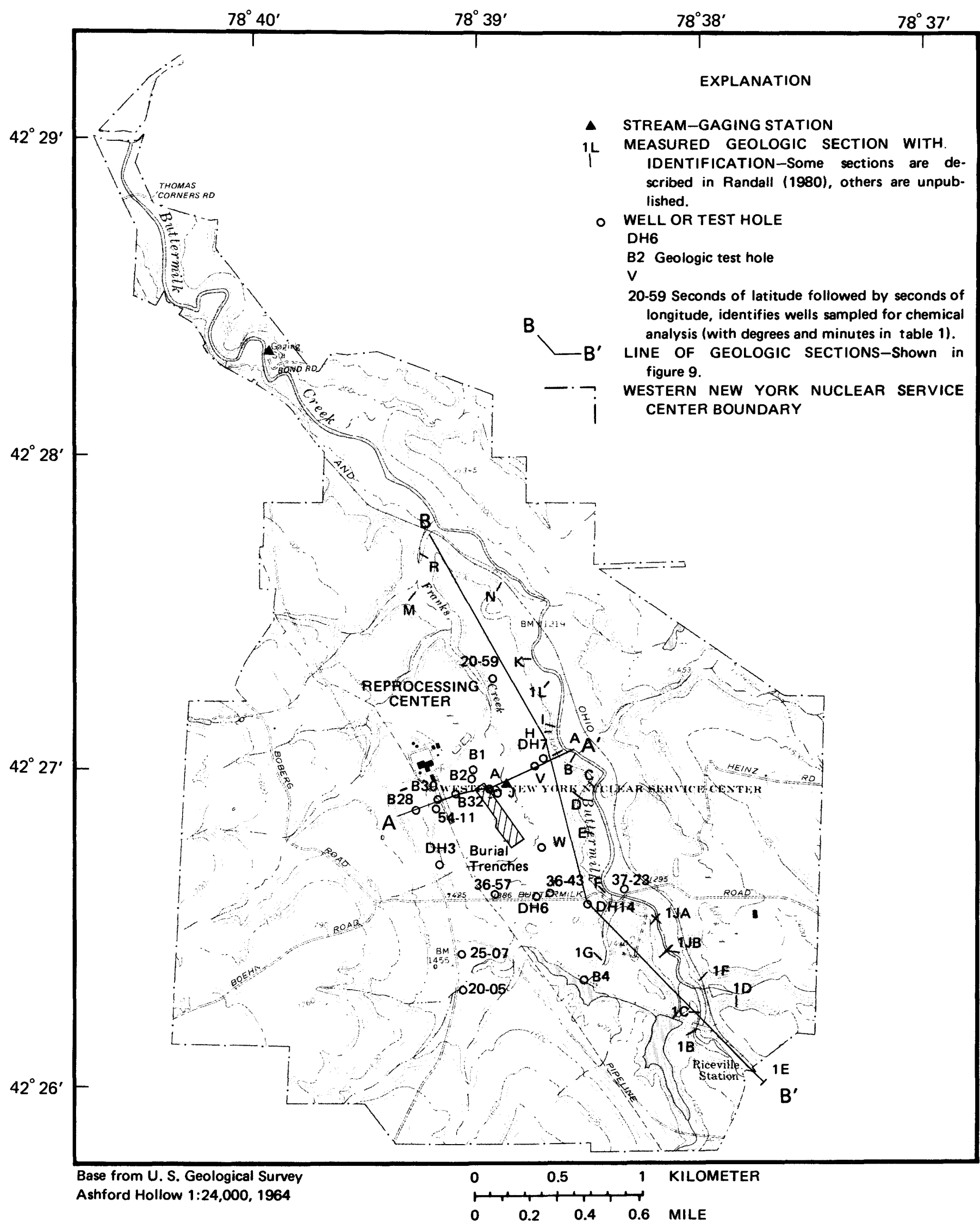

FIGURE 2.-Location of reprocessing center, waste-burial trenches, streams, wells, test holes, and geologic sections within Western New York Nuclear Service Center. 
Creek (figs. 1 and 2). All three streams exhibit wide variations in flow, as indicated in figure 3 , but differ substantially in flow per unit area at low flow. Here, as in most of the Northeast, low flow per unit area is largely a function of the percentage of the drainage basin overlain by sand and gravel ( $\mathrm{Ku}$ and others, 1975; Thomas, 1966) because these deposits provide most of the water to streams at low flow. Maps by LaSala (1968) and LaFleur (1979) show that Cattaraugus Creek drains a larger proportion of stratified drift and alluvium than Buttermilk Creek and that Franks Creek upstream from the gage drains virtually none.

The temporal distribution of surface runoff, by month, for Cattaraugus Creek at Gowanda, $25 \mathrm{~km}$ below the mouth of Buttermilk Creek, is shown in figure 4. The percentage of annual runoff during the summers of 1975-79, when this study was in progress, was slightly higher than the long-term average. The general pattern, however, is typical of streams in the Northeast. High runoff occurs during March and April as a result of snowmelt, minimal evapotranspiration, and high ground-water levels. Low runoff occurs through the summer because of high evapotranspiration and low groundwater levels.

More detailed analyses of the flow regime of these and nearby streams are given in Harding and Gilbert (1968), Dana and others (1978), Boothroyd and others (1979), and Ragan and others (1979).

\section{GEOLOGY}

\section{BEDROCK}

Bedrock in the vicinity of the burial site generally is a sequence of shales with some siltstones of the Devonian Canadaway Group (Chadwick, 1933) about $300 \mathrm{~m}$ thick that dip gently southward at 6 to $8 \mathrm{~m} / \mathrm{km}$ (LaSala, 1968). The log of a deep core hole near the burial site (de Laguna, 1972) shows the upper $180 \mathrm{~m}$ of bedrock to consist of thin beds of gray shale and silty shale and a few scattered thin beds of light-gray calcareous siltstone. Virtually no folding or faulting of the upper layers of bedrock is evident, but joints or fractures are common. A study of bedrock jointing in core holes and exposures near the site (G. H. Chase, U.S. Geological Survey, written commun., 1969; quoted in part by Sun and Mongan, 1974) indicates that all joints are vertical or nearly so; most are about $30 \mathrm{~cm}$ in length, spaced $60 \mathrm{~cm}$ apart on the average, and oriented N. $68^{\circ}$ E. or N. $45^{\circ}$ W. At least four out of five are tightly closed.

Relief of the bedrock surface between hills and adjacent valleys is as great as $300 \mathrm{~m}$. Multiple glacial advances have had a strong influence on the present drainage system, but the arrangement of the major hills and valleys seems to be inherited from an earlier time.

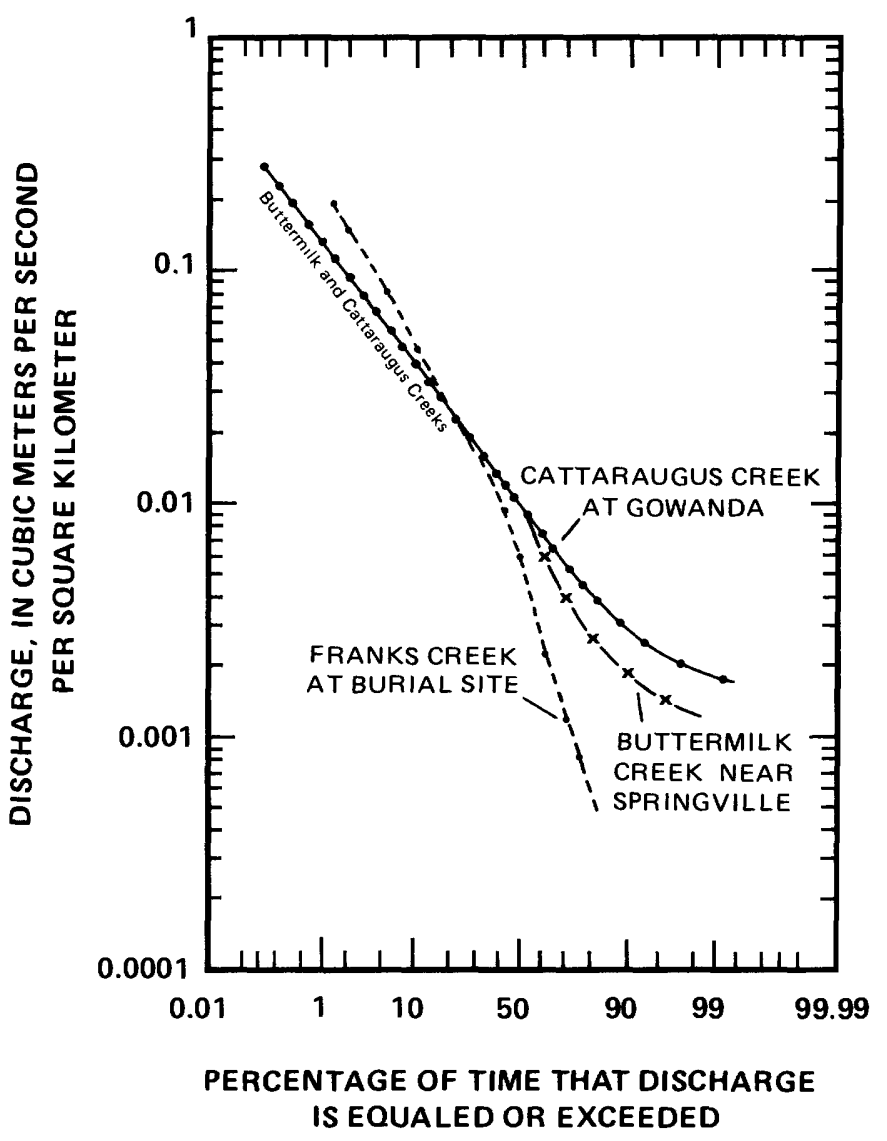

FIGURE 3.-Duration curves of daily flow for Cattaraugus, Buttermilk, and Franks Creeks, 1940-78. Curve for Cattaraugus Creek was compiled from records of daily flow at Gowanda (figure 1) for those 38 years. Curves for Buttermilk Creek and Franks Creek are based on records for 1961-68 and 1975-79, respectively, adjusted to $1940-78$ by multiplying each ordinate by the ratio of flow-duration values of Cattaraugus Creek for 1940-78 to flowduration values for the latter periods.

Before glaciation, the entire area probably drained northward to Lake Erie through several parallel valleys (Calkin and others, 1974, p. 250). As the glaciers moved southward, they widened the north-south valleys into glacial troughs characterized by truncated spurs, U-shaped transverse profiles, and unusually deep floors (Muller, 1977a). The glaciers blocked the northward drainage, forcing meltwater to cut new channels southward or westward through former divides. The present westward course of Cattaraugus Creek (fig. 1) transects several north-south valleys.

The bedrock-surface configuration in Buttermilk Creek valley near the burial site has been fairly well defined (Randall, 1980, and fig. 5). The thalweg of the bedrock valley lies 90 to $120 \mathrm{~m}$ below the present creek channel, or about $150 \mathrm{~m}$ below the general land surface. At the burial site, bedrock is about $116 \mathrm{~m}$ below land surface. On the larger hills near the site, bedrock is mantled in most places by 1.5 to $9 \mathrm{~m}$ of till (LaFleur, 1979). 


\section{GLAGIAL DEPOSITS}

Continental ice sheets advanced across Buttermilk Creek valley at least four times during the Quaternary Period. LaFleur (1979) identified two drift sheets of late Wisconsinan age within the valley, both associated with ponded water and followed by ice-free fluvial erosion and deposition. Deposits from two earlier glaciations (Illinoian and middle Wisconsinan age) have not been recognized in Buttermilk Creek valley. However, the fact that remnants of these glaciations have been mapped in areas to the south (LaFleur, 1979; Muller, 1977b) indicates that the area near the burial site was once covered by the two older ice sheets.

Much of the sediment deposited in this region by ice sheets or associated meltwater consists of silt and clay because bedrock for many kilometers to the north is predominantly shale and siltstone, which readily break down to clay- and silt-size particles during glacial or fluvial erosion. Temporary glacial lakes formed in the valleys as glaciers blocked the northward drainage of streams, trapping large volumes of silt and clay. Some of these lacustrine deposits have been preserved, whereas others became sources of fine-grained sediment to the glaciers that moved across them. Sand and gravel were deposited locally, chiefly in deltas where streams entered glacial lakes and on the flood plains and alluvial fans of streams that formed during ice-free interstadial episodes.

Generally, 80 to 95 percent of the pebbles and presumably most of the smaller grains in the tills of this region are fragments of local bedrock. Some fragments, however, are crystalline rock from Canada, red and white sandstone, or gray or blue-gray dolomite and limestone from northern New York. The carbonate rock fragments probably cause higher concentrations of calcium, magnesium, and bicarbonate in the ground water than would be expected if ground water were in contact with only local bedrock.

\section{POSTGLACIAL EROSION}

Immediately after retreat of the last glacier and the subsequent draining of proglacial lakes, meltwater from ice to the north and runoff from hillsides spread gravel over substantial parts of the valley floors in Cattaraugus Creek basin, including Buttermilk Creek valley. Soon, however, incision by Cattaraugus Creek west of Springville (fig. 1) initiated a phase of erosion in the region upstream that continues to the present. Cattaraugus Creek and Buttermilk Creek were already incised to within $3 \mathrm{~m}$ of the present stream channels 2,000 to 4,000 years ago, as indicated by radiocarbon dating of wood samples collected by R. G. LaFleur from low terraces along these streams (V. J. Janzer, U.S. Geological Survey, written commun., 1976). On the assumption that incision began about 13,000 years ago, when meltwater ceased carrying outwash southward to Cattaraugus Creek, LaFleur (written commun., 1980) calculated the average rate of downcutting of Buttermilk and Cattaraugus Creeks to be $60 \mathrm{~cm}$ per century in drift

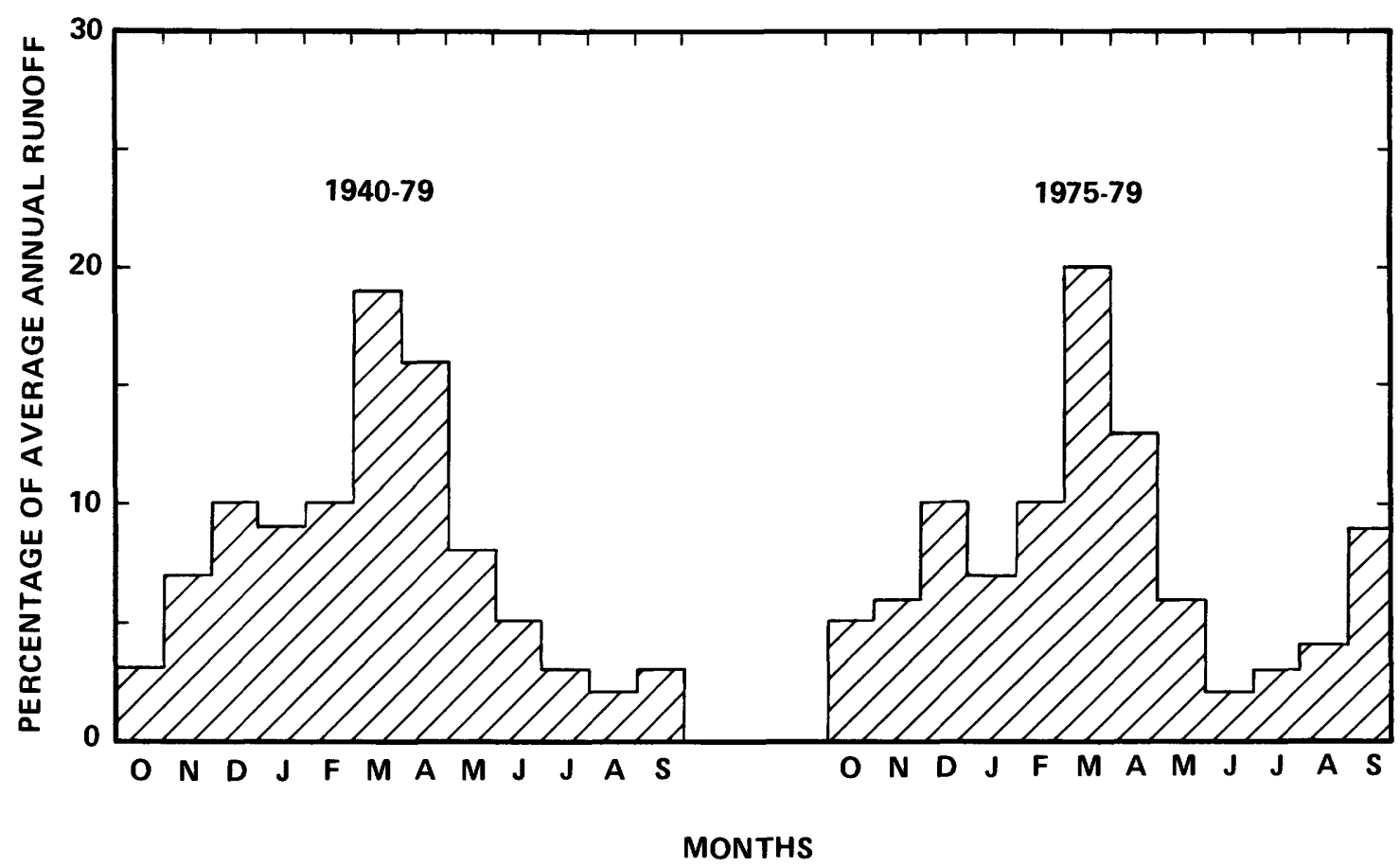

FIGURE 4.-Monthly distribution of average annual runoff, Cattaraugus Creek at Gowanda. 


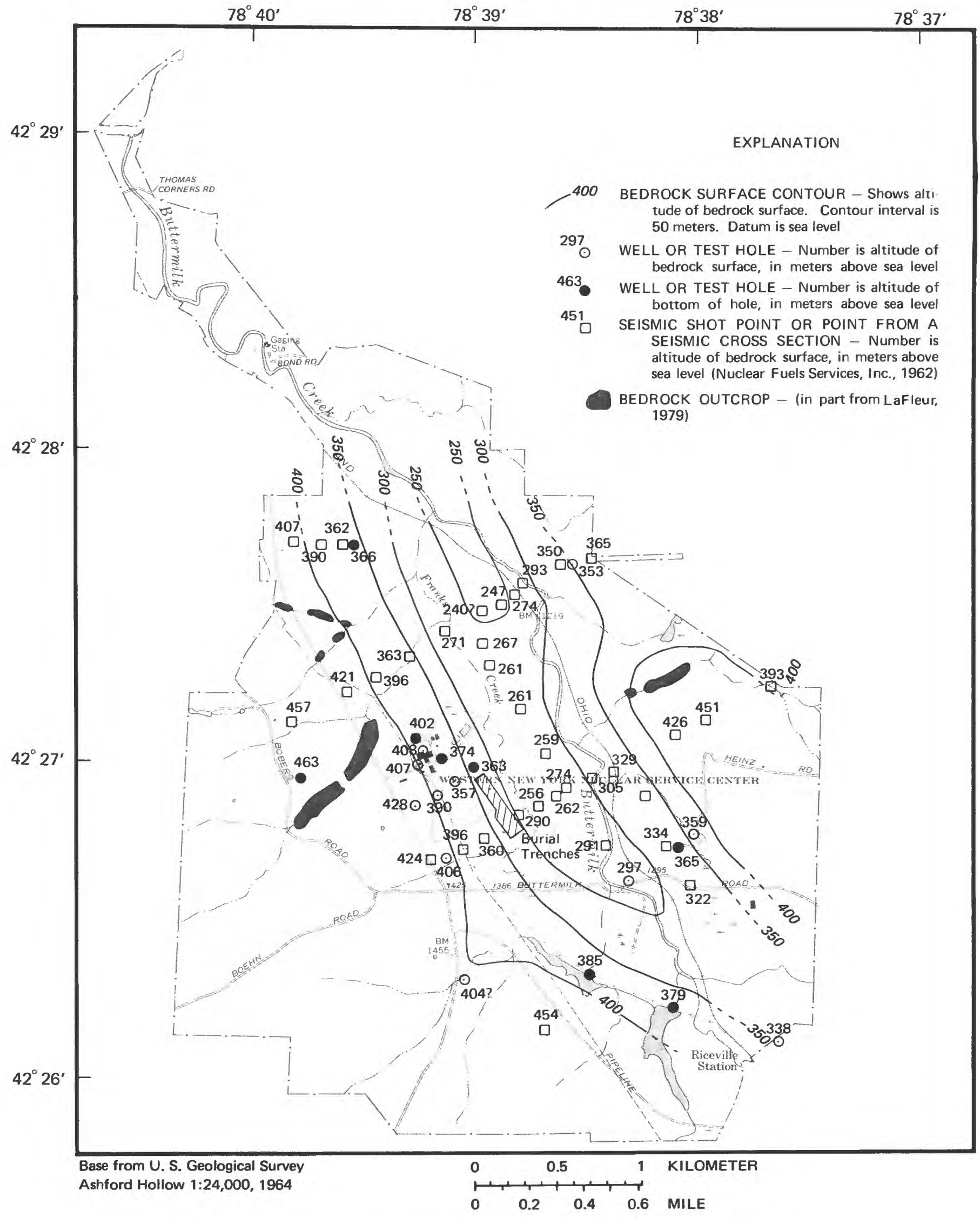

FIGURE 5.-Bedrock-surface altitude in Buttermilk Creek valley (modified from Randall, 1980). 
and about $33 \mathrm{~cm}$ per century in bedrock. Because of this deep postglacial incision and the fine-grained texture of the till and lacustrine sediments, the bluffs along these streams are susceptible to mass wasting. The slopes are covered with 30 to $90 \mathrm{~cm}$ of colluvium; larger slumps and shallow-seated rotational slides also are common.

\section{GROUND WATER}

\section{OCCURRENCE AND MOVEMENT}

In general, Buttermilk Creek valley contains few productive aquifers, although ice-contact sand and gravel occupies a saddle at the headwaters of Buttermilk Creek south of West Valley, and a few wells in the valley penetrate gravel layers, lenses, or pockets at depths of 12 to $120 \mathrm{~m}$ that are capable of yielding 38 to $190 \mathrm{~L} / \mathrm{min}$. The shale bedrock is tapped by several domestic wells, but yields are small. The upper $3 \mathrm{~m}$ of bedrock locally contains abundant fractures and, less commonly, crumpled and broken rock. Maximum well yields from this zone range from 40 to $60 \mathrm{~L} / \mathrm{min}$; wells penetrating bedrock elsewhere, where the fractures or crumpled zone were absent, generally yield 0 to $25 \mathrm{~L} / \mathrm{min}$ (LaSala, 1968, p. 25-26). These yields are presumably based on drillers' tests of typical domestic wells. The average hydraulic conductivity of the uppermost $3 \mathrm{~m}$ of bedrock, where fractured, is about $10^{-5} \mathrm{~cm} / \mathrm{s}$, as derived from typical drawdowns from drillers' tests at the yields indicated; within the next 30 to $60 \mathrm{~m}$ it is about $10^{-7} \mathrm{~cm} / \mathrm{s}$.

Ground water in the region tends to flow downward within the higher hills, laterally beneath low hillsides and terraces, and upward near major streams, as shown in figure 6 and described by LaSala (1968). Downward flow within the higher hills is evidenced by lower water levels in deeper wells. Upward flow near major streams is evidenced by flowing wells, which indicate an upward hydraulic head gradient (fig. 6). Several flowing wells are found along Cattaraugus Creek near Gowanda and Arcade (fig. 1), and another (well 10-35 in fig. 1) is in the valley of Connoisarauley Creek, $5.5 \mathrm{~km}$ west of the site.

Regional flow patterns are also evidenced by the distribution of ground water that contains chloride concentrations above the 2 to $25 \mathrm{mg} / \mathrm{L}$ typical of shallow wells in this region (table 1), as explained by LaSala (1968, p. 60-61). Chloride concentrations of several hundred $\mathrm{mg} / \mathrm{L}$ or more are universal in the shales and siltstones of this region beneath the zone of fresh water. Depth to high-chloride water usually is much less beneath the valley floors than beneath the hills. The occurrence of high chloride concentrations in wells suggests that water comes from the deeper, more regional flow system. Some high-chloride water may discharge into Buttermilk Creek 2 or $3 \mathrm{~km}$ above its mouth (fig.

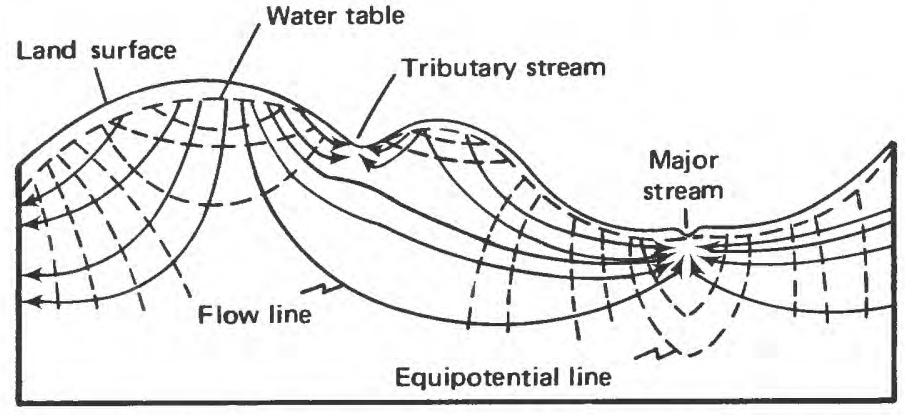

FIGURE 6.-Vertical section showing typical ground-water flow patterns in the region near West Valley (from LaSala, 1968).

2), just upstream from where it flows over bedrock, as indicated by samples collected July 4, 1963 (Archer and others, 1968; Harding and Gilbert, 1968). However, a well next to Buttermilk Creek (well 37-23, in fig. 2), about $700 \mathrm{~m}$ southeast of the burial site, is finished in gravel just above bedrock beneath more than $75 \mathrm{~m}$ of clayey drift; that well has a water level $3 \mathrm{~m}$ below the creek and yields water having only $21 \mathrm{mg} / \mathrm{L}$ chloride (see sample 17 in table 1). This suggests that the reach of Buttermilk Creek adjacent to the burial site is not a discharge point for a regional flow system.

The effects of variations in permeability of earth material are not easily incorporated in an idealized sketch such as figure 6 . The bulk of the subsurface flow occurs close to and subparallel to land surface. Where surficial sand and gravel (alluvium or outwash) overlies till or lake deposits, most ground water flows laterally through the sand and gravel to streams or springs. Where till or lake deposits occur at land surface, which is the case at the burial site, the top meter contains numerous secondary openings such as cracks, root holes, and mole runs that make it relatively permeable, so that the principal subsurface flow, again, is lateral. Of the water that does penetrate vertically downward through the till or lake beds, some may be diverted laterally through sand layers, fractures in the top of bedrock, or bedding-plane joints within the bedrock toward points of discharge, rather than penetrating to depths suggested in figure 6 . Accordingly, the regional flow system of water moving downward from the hills to discharge points along major streams several kilometers away is probably a very small component of total subsurface flow.

\section{CHEMICAL QUALITY}

Calcium and bicarbonate are the predominant constituents of most ground water in and near Buttermilk Creek valley. However, wells in areas of regional discharge or unusually deep wells may tap water having elevated concentrations of sodium chloride; these wells may also have little or no sulfate because of reduction to hydrogen sulfide (LaSala, 1968). Several analyses 


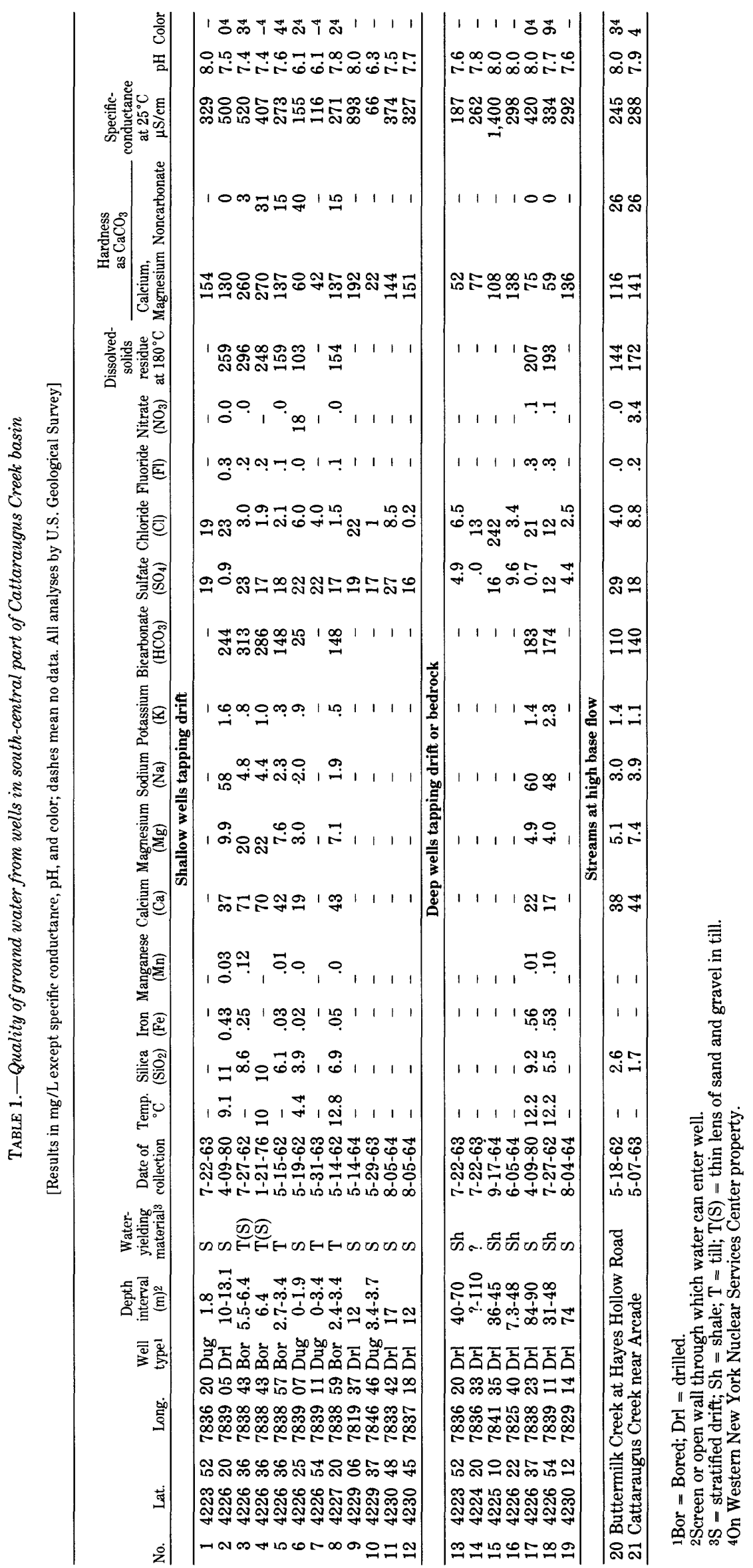


of water from wells in the vicinity of Buttermilk Creek valley and analyses of samples from Cattaraugus and Buttermilk Creeks on dates when streamflow consisted largely of shallow ground-water discharge (LaSala, 1968) are given in table 1.

LaSala (1968) reported that, in general, ground water at shallow depth in unconsolidated deposits is lower in dissolved solids than water in the underlying bedrock. The water-quality data in table 1 show little evidence of this, but calculations based on samples from Buttermilk Creek and hydrograph separation techniques (LaSala, 1967) suggest that ground water in shallow aquifers averages about $150 \mathrm{mg} / \mathrm{L}$ dissolved solids, whereas small amounts of more highly mineralized water are discharged from deeper aquifers. Other factors that may influence the chemical quality of ground water include well construction (LaSala, 1968, p. 59), percentage of exotic limestone fragments in the drift (Seaber and Hollyday, 1964), local sources of pollution (LaSala, 1968, p. 65), and the residence time of water in the various earth materials.

\section{WASTE-BURIAL TRENCHES}

Studies in $1960-61$ by the New York State Atomic and Space Development Authority (now the New York State Energy Research and Development Authority), the New York State Department of Transportation, the New York State Geological Survey, and the U.S. Geological Survey described the geology and ground-water hydrology at the proposed Western New York Nuclear Service Center. Results of these studies were not published separately but were incorporated in a report by the site operator (Nuclear Fuels Services, Inc., 1962).

The Center, established in 1961, was designed primarily for chemical reprocessing of partly spent fuel rods from nuclear powerplants and for storage and burial of resulting wastes. A State-licensed burial ground for commercial low-level radioactive wastes, $300 \mathrm{~m}$ southeast of the reprocessing plant and adjacent to Franks Creek (fig. 2), was also established and was operated from November 1963 until May 1975, during which time more than $67,000 \mathrm{~m}^{3}$ of waste was buried in a series of trenches excavated in fine-grained till.

\section{CONSTRUCTION AND CONTENT}

The arrangement of the burial trenches is shown in figure 7 . Each trench is about $6 \mathrm{~m}$ deep, $10 \mathrm{~m}$ wide at the surface, and between 115 and $215 \mathrm{~m}$ long, except trench 6 , which actually is a series of auger holes, and trench 7 , which is essentially a concrete vault. Each was excavated in successive segments. Normally only 30 to $60 \mathrm{~m}$ was open at any given time, and less than $15 \mathrm{~m}$ of trench floor was exposed in front of the leading edge of the waste pile. This practice minimized the capture of precipitation and runoff (Giardina and others, 1977). Nevertheless, water accumulated on the floor of open trenches and, although most of it was removed by periodic pumping, some remained as standing water within the trenches after emplacement of the covers.

The trenches were excavated by bulldozer. Both ends of each trench were sloped to allow access. Burial of wastes began at one end of the trench after a short section was excavated ( 15 to $30 \mathrm{~m}$ ). Trucks carrying wastes would park next to the trench, and the wastes were either dumped or unloaded by a crane. Wastes, commonly packed in steel drums and pails ranging in capacity from 19 to $210 \mathrm{~L}$ and in rectangular containers made of cardboard, fiberboard, wood, and concrete, were initially unloaded randomly without being stacked or arranged, but starting with trench 8 or perhaps sooner, metal drums were stacked on their sides by hand to form partitions. Concrete casks and other heavy metal or wooden containers, as well as containers with abovenormal levels of external radiation, were placed by crane at the bottom of the trenches between the partitions (Giardina and others, 1977), and miscellaneous wastes were placed on top of them. Several loads of dirt and building rubble were also dumped into the trenches, and at least two semitrailers, presumably filled with radioactive waste, were buried in trench 9 . The length of each trench was extended by backing the bulldozer down the remaining access ramp toward the refuse and having it remove some of the till on its upward pass. The newly excavated till was placed temporarily on top of the adjacent trench until needed to cover newly buried waste (Giardina and others, 1977). Kelleher (1979) noted that the procedure of temporarily surcharging each trench with till from the next trench was neither required nor consistently practiced before trench 8 was excavated. Trenches 5 and 14 (fig. 7) did not receive any surcharge because they were the last trenches completed in their respective areas.

All trenches except 6 and 7 were excavated and completed in numerical order, starting in November 1963 and continuing to May 1975; trenches 6 and 7 were set aside for the burial of special materials of high specific activity (Prudic, 1978; Kelleher, 1979). Trenches 1 and 2 were excavated end to end. Trenches 1 through 4 initially were covered together beneath a single mound of till, but when ponding and erosion resulted (Kelleher, 1979, p. 846), an individual mound was constructed over each of trenches 1 through 4 in the fall of 1968 and over each trench completed thereafter. This technique, which was approved by the State in 1968 with minor revisions, 


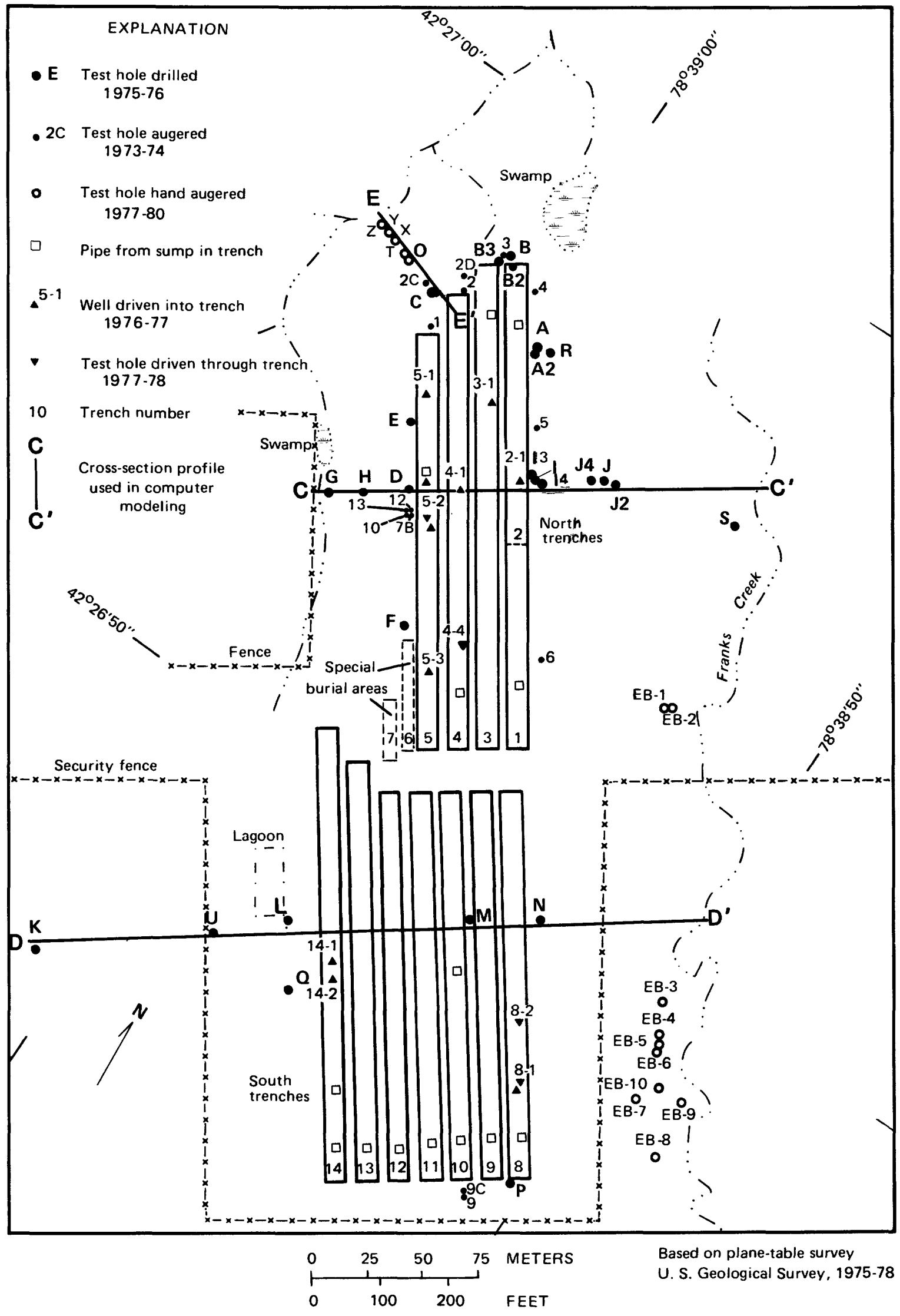

FIGURE 7.-Locations of waste-burial trenches and nearby test holes and wells. Site location is shown in figures 1 and 2. 
included a thicker cover and was intended to reduce the infiltration of precipitation into the trenches (Kelleher, 1979, p. 846).

Additional cover material was added to trenches 1 through 4 in August 1969 when trench 5 was completed. All south trenches except 14 were covered by additional material for periods ranging from 6 months (trench 11) to 33 months (trench 8 ) before the covers were finally graded to their July 1975-78 level. Table 2 shows the dates when trenches were completed and covered and when they were last graded to the level prevailing at the start of this study.

In an attempt to explain the water-level trends that subsequently developed at the south trenches (8-14), a description of the types of waste containers, and their volumes, was obtained from burial records. A summary for trenches 8 through 14 is given in table 3 . The totals for trenches 8 through 11 differ slightly from those presented by Kelleher and Michaels (1973) and Giardina and others (1977), who classify the waste in trenches 1 through 11 according to the type of industry or institution from which it was received.

Trenches 9 through 12 contain slightly less waste than trenches 13 and 14 because they are shorter, even though the southern $40 \mathrm{~m}$ of trench 14 was not filled with waste but with reworked till. Trench 8 , which has the same outside dimensions as trenches 9 through 12 , contains at least 30 percent more waste. The only procedural difference in burial practices among these trenches was that parts of trenches 9 and 10 were not used because of collapsing side walls (A. G. Bockleman, Nuclear Fuel Services, oral commun., 1981). According to Bockleman, variations in the amount of waste buried in each trench are caused by the shape and type of waste containers. For example, paper, cardboard, and fiberboard are more readily compressed than wood, metal, or concrete; thus, the greater amount of waste in trench 8 can be explained to some extent by its greater amount of cardboard, paper, and fiberboard containers. The smaller amount of these types of containers in trenches 11 through 14 than in the earlier trenches probably coincides with closing in 1972 of the reprocessing plant, which used the cardboard containers routinely.

\section{TEST HOLES AND WELLS}

Several sets of test holes and wells have been installed near and within the burial site since 1960. (Locations are shown in figs. 2 and 7.) Because each set was numbered independently and the records were not compiled uniformly, an explanation of the records and numbering systems is given below.

More than 100 test holes were constructed in 1960-61 as part of the initial study of the Center (Nuclear Fuels Services, Inc., 1962). Those test holes were designated
TABLE 2.-Dates of trench completion and regrading

[Trench locations are shown in fig. 7]

\begin{tabular}{|c|c|}
\hline $\begin{array}{cc}\text { Trench } & \begin{array}{c}\text { Date completed and } \\
\text { totally covered }\end{array} \\
\end{array}$ & $\begin{array}{c}\text { Date cover was regraded } \\
\text { to level of } 1975-78\end{array}$ \\
\hline 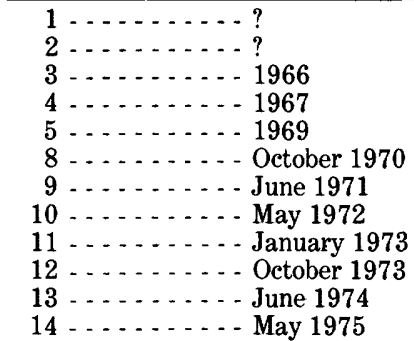 & $\begin{array}{l}\text { August } 1969 \\
\text { August } 1969 \\
\text { August } 1969 \\
\text { August } 1969 \\
\text { August } 1969 \\
\text { July } 1973 \\
\text { July } 1973 \\
\text { July } 1973 \\
\text { July } 1973 \\
\text { June } 1975 \\
\text { June } 1975 \\
\text { June } 1975\end{array}$ \\
\hline
\end{tabular}

as either PAH (power auger hole) or DH (drill hole), followed by a serial number. The $\mathrm{DH}$ holes were drilled to depths of $65 \mathrm{~m}$ or to bedrock, whichever came first, whereas most PAH holes were augered to depths less than $10 \mathrm{~m}$. Later, test holes were drilled by consultants to the site operator to obtain information on soil conditions at the sites of proposed structures, and more than one set of numbers was used. Several of these test holes are cited in this report and are preceded by the letter B (figs. 2 and 9).

During 1973-74, the site operator had a local contractor auger several test holes adjacent to the burial trenches as part of a project funded in part by the New York State Atomic and Space Development Authority and the U.S. Environmental Protection Agency to determine the rate of radionuclide migration at the burial ground. Data from these holes are published in several reports, including Duckworth and others (1974), Matuszek and others (1976), Giardina and others (1977), and $\mathrm{Lu}(1978)$. These test holes were assigned numbers from 1 to 13; where more than one hole was augered near the same location, the numbers are followed by letters; for example, holes $2,2 \mathrm{~B}$, and $2 \mathrm{C}$.

The fate of most of these test holes is not known. Records of the drilling procedures and results do not indicate whether they were backfilled or plugged; apparently most were allowed to collapse naturally upon withdrawal of augers or driller's casing.

Several test holes were drilled or augered from 1975-79 near or between the burial trenches as part of the U.S. Geological Survey study described herein. Most were drilled by air-rotary equipment as described by Prudic and Randall (1979, p. 888); a few were drilled by alternately driving casing and removing material with soil-sampling equipment, as described by Prudic (1979a); two were drilled by cable-tool equipment; and several were augered either with a drill rig or by hand to depths of 2 to $5 \mathrm{~m}$ near the trenches or along or at the base of slopes north and east of the burial ground. Nearly all contained one or more piezometers surrounded by an envelope of sand, and all were backfilled with cement grout. In later holes, thin layers of powdered bentonite were used in addition to the cement grout. All are iden- 


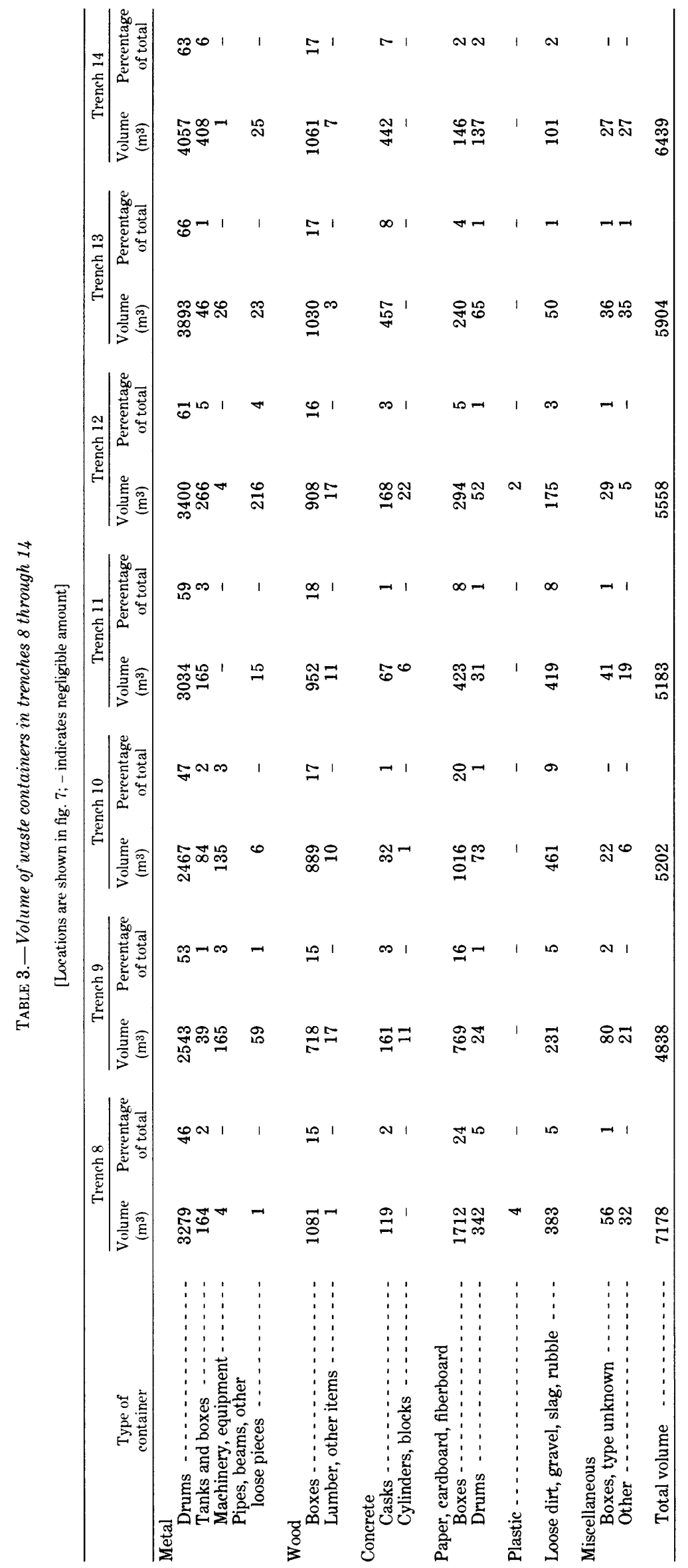


TABLE 4.- Stratigraphy of Quaternary sediments in central Buttermilk Creek valley, Cattaraugus County, N.Y.

[Locations (Riceville Station, Bond Rd., etc.) are shown in fig. 2]

\begin{tabular}{|c|c|c|c|}
\hline Unit & Thickness & Lithology and distribution & Origin \\
\hline (1) & $\begin{array}{l}\text { Slopes: typically } 0.3-1 \mathrm{~m} \\
\text { Elsewhere: } 0\end{array}$ & $\begin{array}{l}\text { A layer of chiefly soft, plastic pebbly silt (reworked till) } 0.3 \text { to } 1 \\
m \text { thick on all slopes, also local slump blocks several meters } \\
\text { thick. }\end{array}$ & $\begin{array}{l}\text { Colluvium, formed by soil creep and local shallow-seated } \\
\text { rotational slumps. }\end{array}$ \\
\hline$(2)$ & $\begin{array}{l}\text { Valley bottoms: } 0.6-2 \mathrm{~m} \\
\text { Elsewhere: } 0\end{array}$ & $\begin{array}{l}\text { Gravel, pebbles to large cobbles, and sand, moderately silty; in } \\
\text { part overlain by clayey silt with organic matter; includes local } \\
\text { masses of colluvium, chiefly reworked till. }\end{array}$ & $\begin{array}{l}\text { Stream alluvium (channel point-bar gravel, and silt deposited by } \\
\text { overbank floods or in channel reaches ponded by mudslides) } \\
\text { locally interbedded with mudslide deposits. }\end{array}$ \\
\hline (3) & $\begin{array}{l}\text { Terraces: } 0.6-2 \mathrm{~m} \text { typical } \\
\text { Elsewhere: } 0\end{array}$ & $\begin{array}{l}\text { Ferruginous gravel and silt, underlies terraces along Buttermilk } \\
\text { Creek. }\end{array}$ & Older alluvium of Buttermilk Creek. \\
\hline (4) & $0-6.2 \mathrm{~m}$ & $\begin{array}{l}\text { Gravel and sand, moderately silty; coarser and siltier on alluvial } \\
\text { fans formed where streams enter Buttermilk Valley at about } \\
437 \mathrm{~m} \text { altitude. }\end{array}$ & $\begin{array}{l}\text { Deposited by upland streams that flowed onto the freshly } \\
\text { exposed till plain, then northwestward, before signiflcant } \\
\text { incision by the present stream system. Alluvial-fan deposition } \\
\text { near the valley wall probably continued after incision by } \\
\text { Buttermilk Creek had begun. Absent on some higher areas of } \\
\text { the till plain and where lingering ice blocks diverted flow. }\end{array}$ \\
\hline (5) & $\begin{array}{l}5 \mathrm{~m} \text { (Riceville Station) } \\
22 \mathrm{~m} \text { (Buttermilk Rd.) } \\
28 \mathrm{~m} \text { (burial site) } \\
37 \mathrm{~m} \text { (RR bridge over } \\
\quad \text { Buttermilk Cr.) } \\
40 \mathrm{~m} \text { (mouth of Franks Cr. } \\
\quad \text { to Bond Rd.) }\end{array}$ & $\begin{array}{l}\text { Till, composed predominantly of clay and silt. Sixteen cores from } \\
\text { drill holes near the burial site contained } 50 \text { percent clay, } 27 \\
\text { percent silt, } 13 \text { percent sand, and } 10 \text { percent fine gravel on the } \\
\text { average. LaFleur (1979) reports that } 10-20 \text { percent pebbles } \\
\text { and cobbles is characteristic of most exposures. Typical } \\
\text { nonsorted till interfingers randomly with a similar till } \\
\text { containing many tiny blebs and torn, deformed wisps of quartz } \\
\text { silt. Although these two subfacies form crudely horizontal } \\
\text { layers, each is internally deformed. Distributed throughout (at } \\
\text { least within boundary of the center) are randomly oriented } \\
\text { pods and irregular lenses of stratified sand and gravel and } \\
\text { rhythmic silt and clay. Excavations at the burial site and } \\
\text { between Franks Creek and Buttermilk Creek (Davis and } \\
\text { Fakundiny, 1978) consistently demonstrate that these } \\
\text { stratified deposits are discontinuous, deformed, and rotated or } \\
\text { transported from their original point of deposition. Although } \\
\text { these lenses constitute only about } 7 \text { percent of core footage } \\
\text { logged (Prudic and Randall, } 1979 \text { ), two-thirds of the U.S. } \\
\text { Geological Survey test holes in } 1962 \text { and } 1975-78 \text { near the } \\
\text { burial site penetrated one or more lenses at depths of } 3 \text { to } 11 \\
\text { m below natural grade. The till is present throughout } \\
\text { Buttermilk Valley below about } 437 \text { m altitude. }\end{array}$ & $\begin{array}{l}\text { Deposited by a tongue of ice that readvanced as far south as } \\
\text { West Valley through ponded water as much as } 125 \mathrm{~m} \text { deep in } \\
\text { Buttermilk Valley. During this readvance, which has been } \\
\text { correlated by LaFleur (1979) with the Lavery readvance in } \\
\text { Ohio, the glacier apparently floated free from the substrate } \\
\text { periodically and allowed beds of silt and clay to accumulate. } \\
\text { Resettling of the ice to the lake floor, possibly in response to } \\
\text { lowering of lake water by subglacial drainage or to more rapid } \\
\text { advance of the glacier, would explain renewed till deposition } \\
\text { as well as the structural deformation observed in both the till } \\
\text { and lacustrine-till subfacies. The apparent abundance of } \\
\text { fragments of water-laid deposits in the upper part of the till } \\
\text { led LaFleur (1979) to suggest a minor ice withdrawal and } \\
\text { readvance across ice-frontal deposits near the end of this } \\
\text { glaciation. }\end{array}$ \\
\hline
\end{tabular}

tified by letters from $\mathrm{A}$ to $\mathrm{Z}$ except a few near Franks Creek, which are designated by the letters EB. Where multiple holes were drilled close to one another, a number follows the letter as described previously. The piezometers are identified by the test-hole letter (and number, if any) followed by a hyphen and a piezometer number; the number 1 is used even if the hole contains only one piezometer. In test holes with more than one piezometer, the piezometers are numbered sequentially from shallowest to deepest; for example, G-1 (shallow), G-2 (intermediate), G-3 (deep).

Wells were driven into the trenches from 1976-79 to sample water and gas (Prudic, 1978), and test holes were drilled beneath the trench floors (after driving closed pipes through the waste) to help define radionuclide migration rates (Prudic, 1979a). Each of these wells and test holes was assigned two numbers separated by a hyphen and followed by a letter, for example, 5-3C. The first number indicates the trench, the second indicates the location along the trench, and the letter distinguishes closely spaced wells near the same location. Some were filled with cement grout; others were left as open pipes for monitoring and sampling (Prudic, 1978, 1979a).

\section{STRATIGRAPHY AND GENERAL GROUND-WATER MOVEMENT AT THE BURIAL SITE}

Radioactive wastes were buried in trenches excavated in a silty-clay till that contains few stones and thin distorted lenses of silt, fine sand, and rarely, coarser sand. The till is covered by thin gravel and sand deposits over much of the Western New York Nuclear Service Center, but these are generally absent near the trenches. The till extends about $28 \mathrm{~m}$ below the pretrench land surface at the burial site and overlies a bedded lacustrine sequence 10 to $20 \mathrm{~m}$ thick that consists mostly of fine sand and silt and in places is capped by a gravel. Beneath the lacustrine sequence is another silty-clay till. Table 4 summarizes the stratigraphy of the sediments near the burial site and describes the origin of each of the units. Figure 8 shows the distribution of surficial deposits, including the area of outcrop of the lacustrine sequence along Buttermilk Creek, and figure 9 shows the stratigraphic relations of units in two vertical sections. Locations of sections are shown in figure 2. 
TABLE 4.-Stratigraphy of Quaternary sediments in central Buttermilk Creek valley, Cattaraugus County, N.Y.-Continued [Locations (Riceville Station, Bond Rd., etc.) are shown in fig. 2]

\begin{tabular}{|c|c|c|c|}
\hline Unit & Thickness & Lithology and distribution & Origin \\
\hline (6) & $0-25 \mathrm{~m}$ & $\begin{array}{l}\text { Layered clay or clay-silt rhythmites; may contain pebbles or } \\
\text { grade upward into layered silty clay with scattered pebbles } \\
\text { and then into till. }\end{array}$ & $\begin{array}{l}\text { Deposited in proglacial lake dammed by advancing ice. Missing } \\
\text { in some places; not easily recognized unless well exposed. May } \\
\text { be grouped with the overlying unit on basis of similar grain } \\
\text { size and frequency with which the till grades into or } \\
\text { incorporates lacustrine beds at various depths. }\end{array}$ \\
\hline (7) & $0-8 \mathrm{~m}$ & $\begin{array}{l}\text { Gravel composed of pebbles and small cobbles, and sand; } \\
\text { typically poorly sorted and moderately silty. Absent near the } \\
\text { burial site and fuel-reprocessing plant (figs. } 8 \text { and 9); present } \\
\text { consistently (but possibly discontinuous) near Buttermilk } \\
\text { Creek. Where more than } 3 \text { m thick, interbedded with pebbly } \\
\text { coarse sand, fine sand, and silt. }\end{array}$ & $\begin{array}{l}\text { At least three modes of deposition are plausible. Deposits east } \\
\text { and southeast of the burial ground may have originated as } \\
\text { deltas in a declining postglacial lake, and (or) as an alluvial } \\
\text { blanket spreading across the former lake floor. Deposits near } \\
\text { the mouth of Franks Creek are thin, } 15 \text { m lower in altitude, } \\
\text { and rest on unit } 9 \text { rather than unit 8; they might have formed } \\
\text { along stream channel(s) during interglacial incision (Erie } \\
\text { Interstade) (LaFleur, 1979). }\end{array}$ \\
\hline (8) & $0-8 \mathrm{~m}$ & $\begin{array}{l}\text { Sand, very fine to fine, well-sorted and stratified, interbedded } \\
\text { with much silt that becomes predominant with depth. Grades } \\
\text { into underlying unit. Absent near mouth of Franks Creek and } \\
\text { generally along the west side of the valley. }\end{array}$ & $\begin{array}{l}\text { Deltaic sediments deposited in a persistent glacial lake, probably } \\
\text { by local streams, as indicated by distribution (fig. } 8 \text { ); } \\
\text { northward flow indicated in two exposures, and gradation into } \\
\text { underlying lake-bottom deposits without an intervening till or } \\
\text { truncation. }\end{array}$ \\
\hline (9) & $6-16(?) \mathrm{m}$ & $\begin{array}{l}\text { Interbedded coarse silt, fine silt, and clay, generally in rhythmic } \\
\text { layers up to several mm thick; some fine silt layers are as thick } \\
\text { as } 30 \mathrm{~cm} \text {, but close inspection commonly reveals regular } \\
\text { partings of coarse silt; olive-gray except clay layers commonly } \\
\text { pale grayish-red. At most locations, some intervals are } \\
\text { marked by widely scattered pebbles, disturbed bedding, and } \\
\text { (or) thin layers, blebs, and irregular masses of reddish-brown } \\
\text { or greenish-gray pebbly sandy silt. This unit is present } \\
\text { everywhere from Riceville Station to mouth of Franks Creek, } \\
\text { except close to sides of valley. }\end{array}$ & $\begin{array}{l}\text { Units } 9 \text { and } 11 \text { consist of bottom deposits in a glacial lake } \\
\text { characterized by icebergs and occasional readvances of a } \\
\text { floating or occasionally grounded ice tongue. The intervening } \\
\text { till layer (unit 10) is inferred to be of Kent age (LaFleur, } \\
\text { 1979); it appears to be a continuous unit but south of } \\
\text { Buttermilk Road incorporates fragments of lacustrine } \\
\text { sediment and may grade into or interfinger with lacustrine } \\
\text { sediment that contains detritus dropped from floating ice. } \\
\text { Furthermore, some borehole logs and geologic sections seem } \\
\text { inconsistent with this simple threefold division of units } \\
\text { (Randall, 1980), perhaps because floating ice tongues that } \\
\text { dropped scattered pebbles and sandy clay blebs in one locality } \\
\text { may have been grounded in another locality and deposited till. } \\
\text { In any case, the deposits below the top of unit } 9 \text { were formed } \\
\text { during repeated ice advance and retreat through proglacial } \\
\text { lake water. }\end{array}$ \\
\hline (10) & $3-10 \mathrm{~m}$ & $\begin{array}{l}\text { Till, similar to unit } 5 \text {, perhaps darker; rare inclusions of grayish- } \\
\text { red till; facies with torn, deformed wisps, slivers, or masses of } \\
\text { coarse silt and in part with low pebble content predominates } \\
\text { south of Buttermilk Road. }\end{array}$ & \\
\hline (11) & $?$ & $\begin{array}{l}\text { Predominantly clay, clayey silt, and silt in rhythmic layers, } \\
\text { commonly disturbed much the same as unit 9; layered fine } \\
\text { sand, coarse sand, and gravels locally present. }\end{array}$ & \\
\hline (12) & $?$ & $\begin{array}{l}\text { Till, much more sandy and stony than units } 5 \text { and } 10 \text {; exposed } \\
\text { and reported in test holes near the side of the valley, atop or } \\
\text { close to bedrock. }\end{array}$ & $\begin{array}{l}\text { May be an upland facies of unit } 10 \text {, or an older till sheet; may } \\
\text { incorporate or grade to silty gravel. }\end{array}$ \\
\hline
\end{tabular}

The stratigraphy of the materials at the burial site plays an important role in the movement of ground water. The upper parts of the underlying lacustrine sequence (units 7 and 8 in table 4) are unsaturated (Prudic and Randall, 1979); however, the deeper lakebottom rhythmites (unit 9) are saturated and provide an avenue for slow lateral flow through coarse silt to points of discharge in the bluffs along Buttermilk Creek (fig. 8). The unsaturated conditions in the lacustrine unit are the result of very low vertical permeability in the till and thus low recharge through the till rather than high horizontal permeability in units 7 through 9 . Nevertheless, the lacustrine sequence acts as a drain to the till and causes downward gradients in the till of 0.7 to 1.0 , even beneath small valleys adjacent to the burial site, as evidenced by hydraulic heads in several nested piezometers. Before Buttermilk Creek cut down through the lacustrine sequence, permitting free drainage along the bluffs, the entire section was undoubtedly saturated. Downward gradients in the till must have been much less pronounced, and lateral or upward gradients might have occurred locally in the till close to the small streams that border the burial site.

LaFleur (1979) proposed that gravel deposited by ancestral Buttermilk Creek in the interstadial interval after deposition of the lacustrine sequence might serve as a drain for adjacent and overlying materials, provided that the gravel had not been eroded away by the advancing ice that deposited the upper silty-clay till (unit 5 in table 4). No substantial springs nor areas of spring sapping that would indicate such a drain have been detected where the gravel and the underlying lacustrine sequence crop out along the steep valley walls of Buttermilk or Franks Creek. Therefore, ground-water discharge from these units must be small enough to seep away without removing the deposits resulting from 


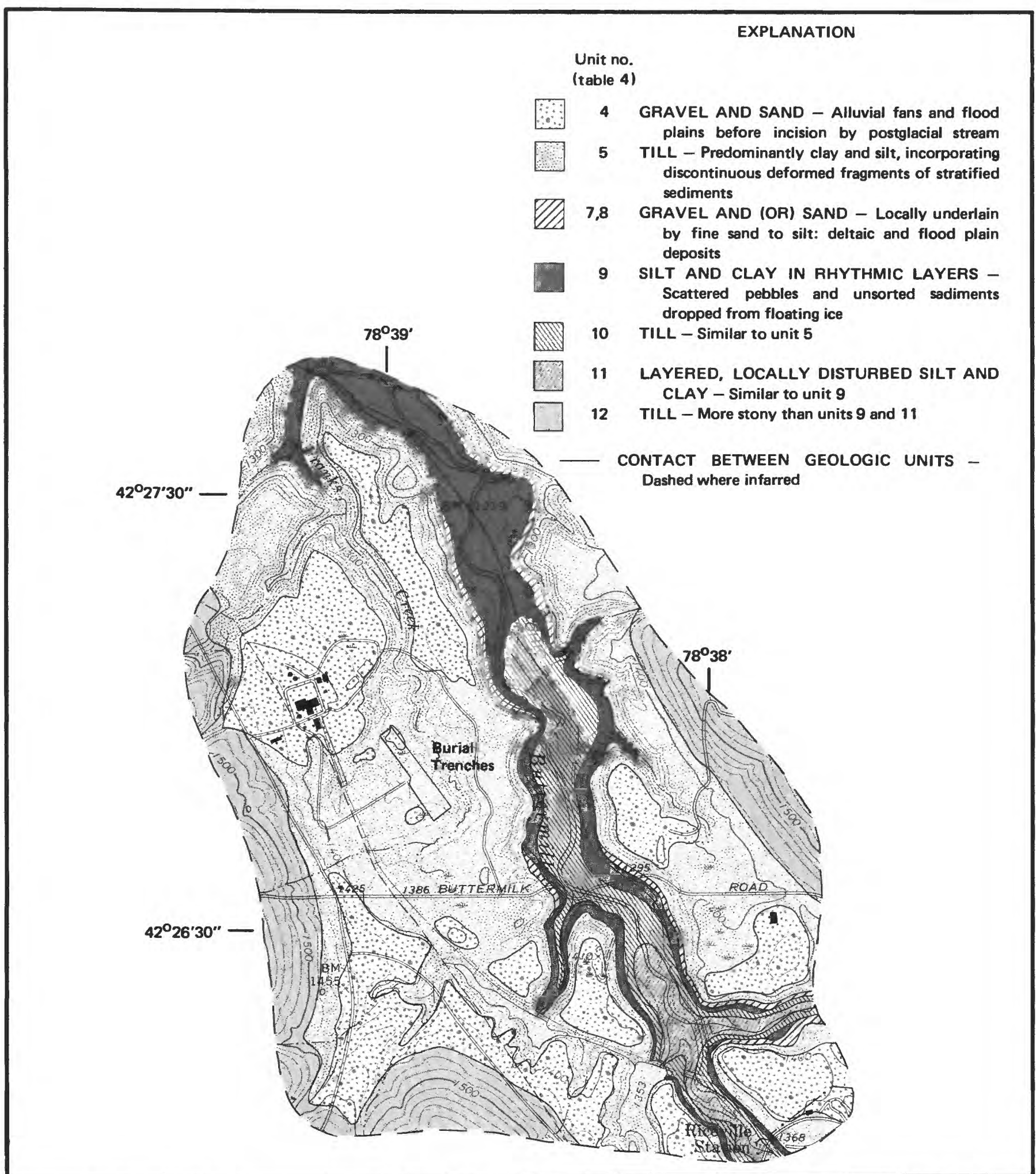

Base from U.S. Geological Survey Ashford Hollow 1:24,000, 1964

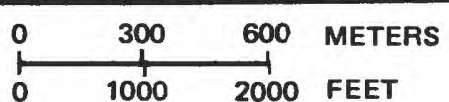

Geology by A. D. Randall modified from LaFleur (1979)

FIGURE 8.-Surficial geology of burial site and vicinity. Units are mantled by a few meters of flood-plain and terrace gravels along Buttermilk Creek and some tributaries (shown in detail by Boothroyd and others, 1979) and by a meter or more of colluvium and landslide blocks on the steep bluffs bordering these streams. 

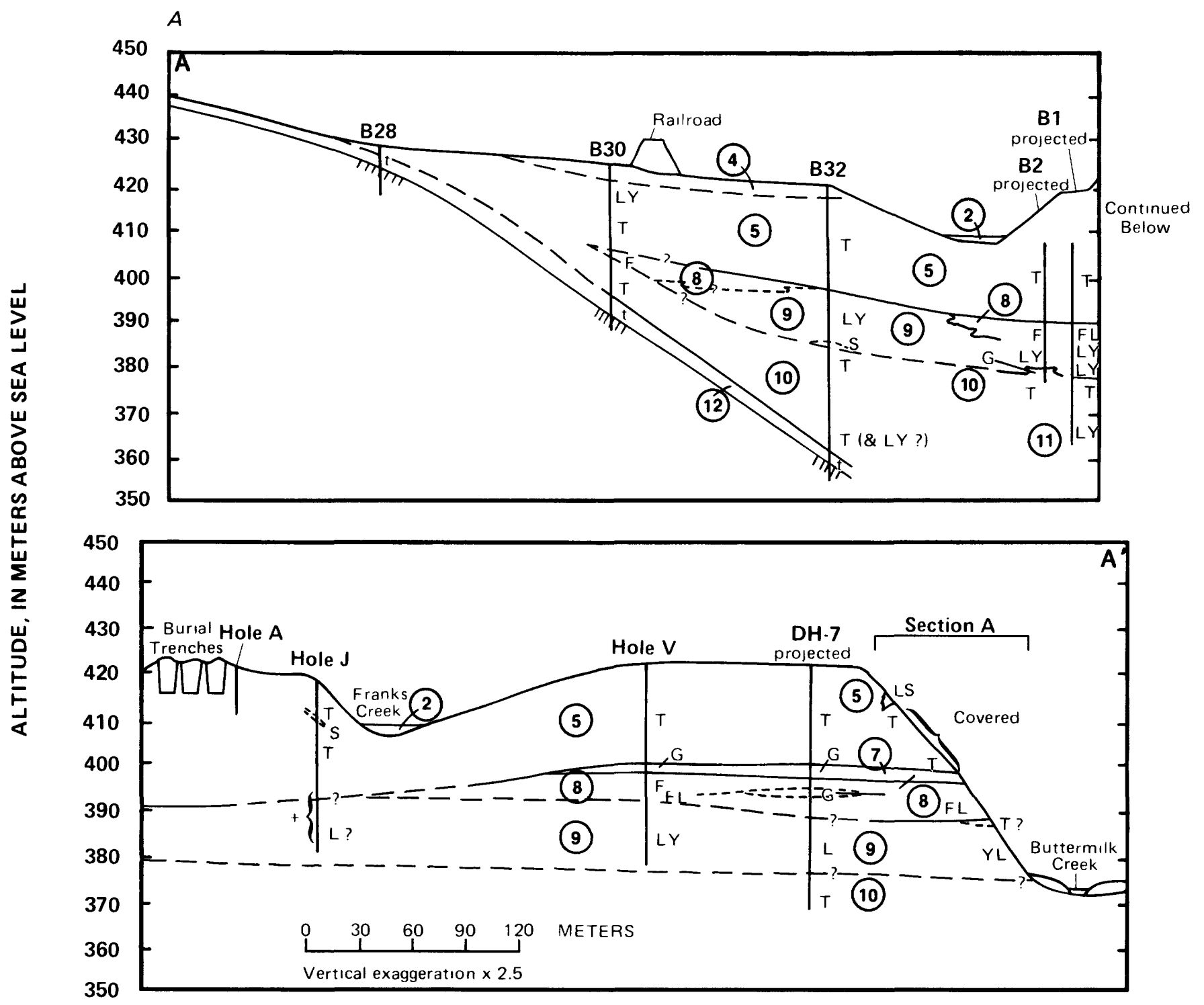

EXPLANATION
A Measured geologic section
T Till, silty clay matrix

Hole A, Hole drilled for USGS study

t Till, stony silty clay

Hole J,

G Gravel

DH-7 Test boring drilled in 1962 as part of site evaluation; drive-spoon samples examıned by geologist.

S Fine to coarse sand

F Fine to very fine sand

B1, B2, etc. Test boring drilled for engineering design of proposed structures; log by Empire Soils Investigations, Inc.
L Silt
$\curlyvee \quad$ Clay
$+\quad$ Log inferred from geophysical data and other wells
(5) (6) etc. Lithostratigraphic units, described in table 4.
$\approx \quad$ Macro-scale folding
(0.3-m amplitude)

$\lambda$ Top of bedrock

FIGURE 9.-A, Section A-A' across and along Buttermilk Creek. All data projected to line of section, as shown in figure 2 (modified from Randall, 1980, figure 2). 


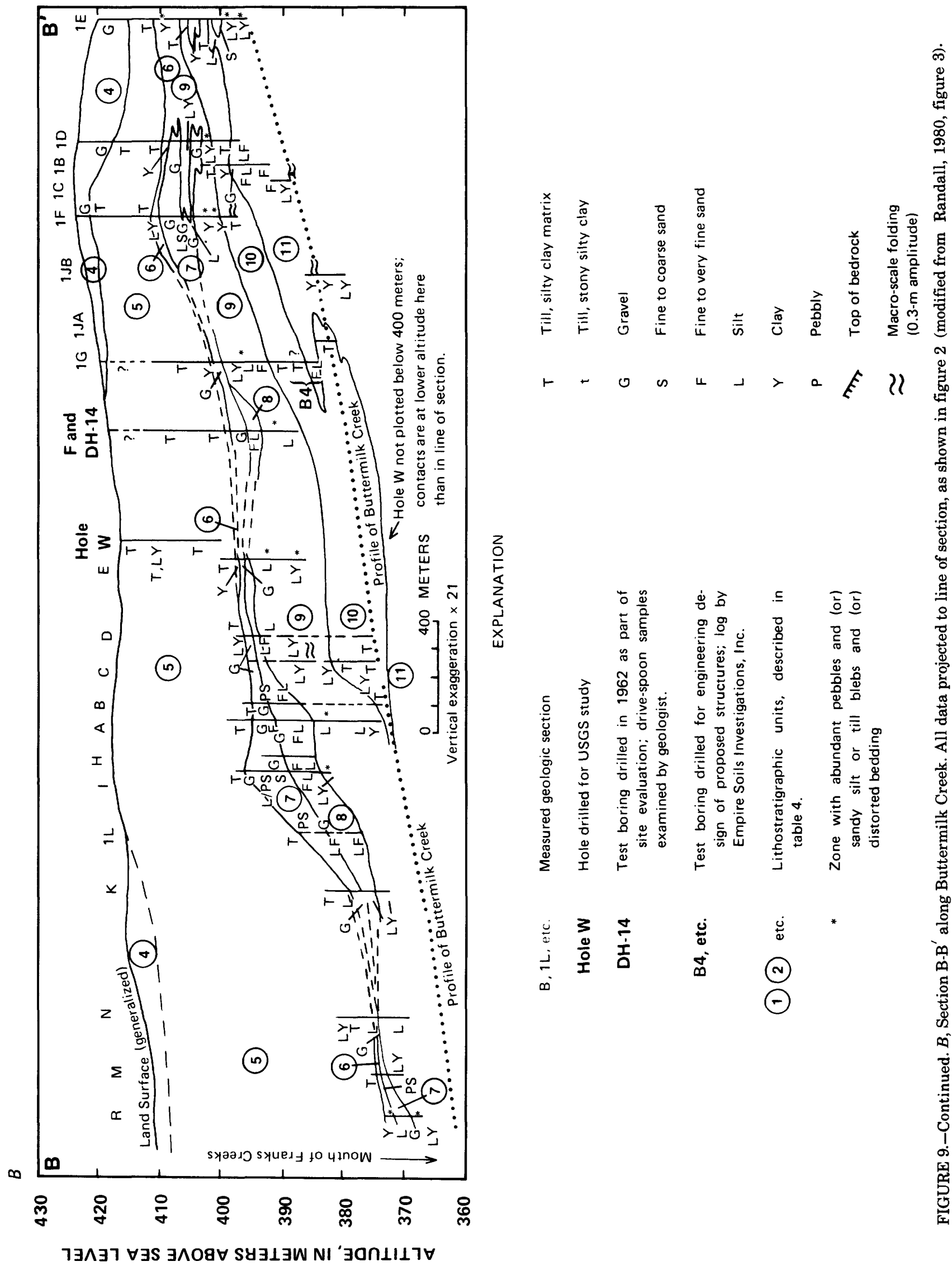


mudflow and soil creep (unit 1 in table 4) that generally mantle the slope, or possibly discharge may occur chiefly where the lacustrine sequence dips down to the grade of the creek some distance to the north (figs. 8 and 9). One small spring was visible through most of 1976 in a fresh slide scar along Buttermilk Creek (Prudic and Randall, 1979, fig. 5) from which water issued at a rate of nearly $1 \mathrm{~L} / \mathrm{min}$ from very fine sand and silt near the contact between units 8 and 9 . The spring was higher in altitude than the water level farther west in piezometers finished in unit 9 ; this could be explained by a greater rate of recharge on the slope near the spring and (or) perhaps by a strong downward vertical gradient across units 9 and 10 such as in the overlying till. A spring of comparable magnitude was noted in May 1980 on a slide scar $600 \mathrm{~m}$ north of the first one.
An idealized vertical section (fig. 10) illustrates the inferred distribution of saturated and unsaturated material within the stratigraphic column at the burial site and the general pattern of subsurface flow; it also includes the gravel drain postulated by LaFleur. This sketch does not represent a specific location (vertical sections showing the distribution of hydraulic head in the till beneath the burial site are presented later); it is intended only to emphasize that nearly all runoff entering the soil flows close to land surface. Where till (unit 5) occurs at land surface, runoff moves as overland sheet flow and shallow subsurface flow and normally reaches stream channels in a few hours. In several areas near the site, storm runoff to nearby surface depressions and gullies is through a network of interlaced mole runs about $15 \mathrm{~cm}$ below land surface that forms a veritable

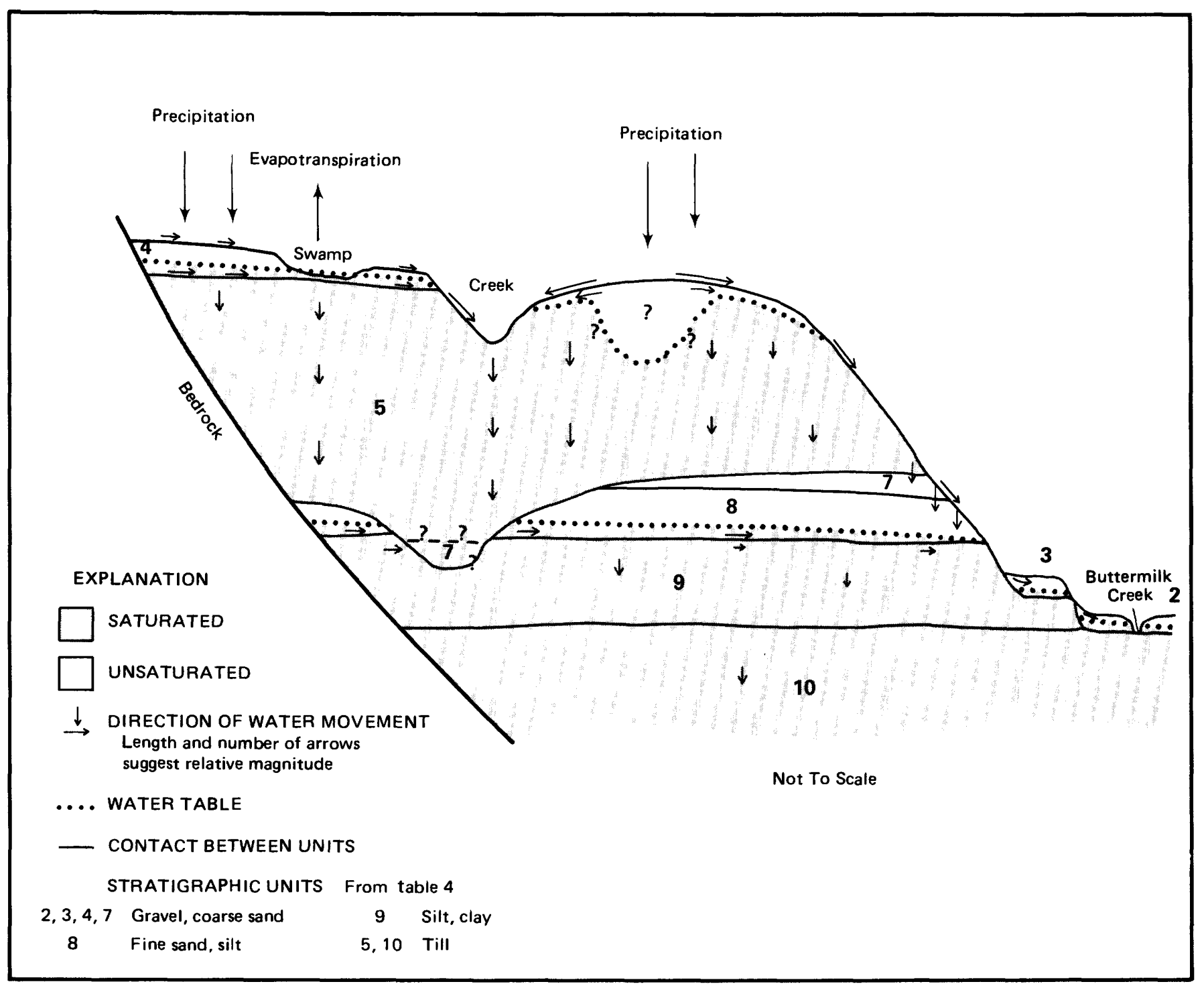

FIGURE 10.-Idealized cross section in vicinity of burial site west of Buttermilk Creek showing inferred distribution of saturated and unsaturated material and general directions of ground-water flow. 
storm-sewer system. In one area about $30 \mathrm{~m}$ northeast of trench 2 (fig. 7), flowing water was heard after a rain storm in May 1976, although no overland flow was visible. Several mole runs were quickly uncovered by shovel, and all found to be serving as water conduits. When one became plugged, water in the upstream segment erupted to the surface as a "wet-weather spring" that briefly yielded several liters per minute. That "spring," and others like it on other occasions, at first drew interest because of its proximity to the burial trenches, but was later disregarded once its origin as a form of overland runoff was understood. Other smaller secondary openings at shallow depth, such as root openings and cracks formed by ice, desiccation, or soil creep may also conduct a small fraction of runoff to streams. Where surficial gravel or sand (units 2-4 in table 4) is present at land surface, some precipitation infiltrates to the water table (fig. 10, unit 4), then moves laterally to stream channels or points of seepage on nearby slopes. The numerous small surface depressions and thick vegetation along channels of small tributary streams result in delayed runoff (as channel storage) and in appreciable evapotranspiration during summer.

Of the 12 geologic units listed in table 4, only unit 4 would qualify as an aquifer; the others are either insufficiently permeable to yield usable quantities of water to wells or are at least seasonally unsaturated. The surficial gravels that form unit 4 are commonly thin and, where incised by streams, are well drained but locally could probably yield several liters per minute to shallow wells. Most of the scattered lenses of sand and gravel within unit 5 are too small to yield usable amounts of water, but a few of the most extensive ones (Davis and Fakundiny, 1978, fig. 11-4) could possibly yield several liters per minute for a few hours.

\section{PHYSICAL AND HYDRAULIC PROPERTIES OF THE TILL}

Detailed hydrologic studies at the burial site were limited to the till (unit 5 in table 4) because the trenches are excavated only in this till, the covers consist only of reworked till, and the studies showed that subsurface radionuclide migration had not extended through or beyond the till. The following paragraphs describe the physical and hydraulic properties of the till.

\section{PHYSICAL AND MINERALOGICAL PROPERTIES}

Particle size of 27 core samples from test holes drilled near the trenches was analyzed by methods described by Morris and Johnson (1966). The results are given in table 5. Of these samples, 16 were till and averaged
49.6 percent clay, 26.7 percent silt, 13.0 percent sand, and 10.7 percent gravel. The remaining 11 samples were collected from disturbed sorted materials within the till. The predominant particle size varied widely from sample to sample in the disturbed sorted materials; 4 of the 11 samples contained predominantly clay-sized particles, 2 were mainly silt, 2 were predominantly gravel, and the others were a mixture of more than one class size. Because the disturbed sorted materials varied widely, no attempt was made to determine an average particle size.

The average porosity of 28 samples of till from all depths was 32.4 percent, with a standard deviation of 4.7. Two samples of interbedded silt and clay had porosities of 34.8 and 33.1 percent. The average dry bulk density (dry unit weight) determined from 17 core samples was $1.82 \mathrm{~g} / \mathrm{cm}^{3}$; Fickies and others (1979) reported five values averaging $1.80 \mathrm{~g} / \mathrm{cm}^{3}$.

Bulk X-ray analyses of seven core samples (table 6) indicate that quartz and illite constitute well over half the material in each of the samples; Whitney (1977) noted that the silt and clay fraction of three samples was predominantly quartz, mica (illite), and chlorite.

Specific storage, defined as the volume of water released from storage under a unit decline in hydraulic head, is equal to the compression of the medium and the expansion of the water. The specific storage of the till near the trenches was determined from four consolidation tests of core samples from depths between 6 and 16 $\mathrm{m}$. The specific storage decreased from $16 \times 10^{-6}$ per $\mathrm{cm}$ at a depth of $5.8 \mathrm{~m}$ to $2 \times 10^{-6}$ per cm at a depth of 16 $\mathrm{m}$ and averaged $8 \times 10^{-6}$ per $\mathrm{cm}$ (Prudic, 1981). These values are in the lower part of a range of values for medium-hard clay quoted by Domenico and Mifflin (1965) and are an order of magnitude less than intergranular specific storage of a fractured clay-rich till near Manitoba,Canada (Grisak and Cherry, 1975).

\section{HYDRAULIC CONDUCTIVITY}

Both field and laboratory tests were made to determine the hydraulic conductivity of saturated till near the burial trenches. In general, values of hydraulic conductivity based on laboratory tests of core samples agreed with values calculated from slug tests in which water was suddenly removed from piezometers screened in the till (Prudic, 1982). Two methods were used to analyze the slug tests. The first method (Cooper and others, 1967) assumed horizontal flow; the second (Hvorslev, 1951) assumed isotropic spherical flow to the piezometer. The average hydraulic conductivity calculated from 12 tests was $6 \times 10^{-8} \mathrm{~cm} / \mathrm{s}$ by the first method and $2 \times 10^{-8} \mathrm{~cm} / \mathrm{s}$ by the second (Prudic, 1982). Individual values are listed in table 7 . 
Horizontal hydraulic conductivity determined from falling-head permeameter tests of nine core samples with zero confining pressure averaged $3.8 \times 10^{-8} \mathrm{~cm} / \mathrm{s}$. Vertical hydraulic conductivity determined from fallinghead permeameter tests of 13 core samples with zero confining pressure averaged $6.2 \times 10^{-8} \mathrm{~cm} / \mathrm{s}$, but in three tests with confining pressures equal to the estimated overburden pressures, vertical hydraulic conductivity averaged $1.6 \times 10^{-8} \mathrm{~cm} / \mathrm{s}$. Vertical hydraulicconductivity values calculated from consolidation tests of six samples of saturated till with confining pressures equal to the estimated overburden pressures (including

TABLE 5.-Particle size of selected core samples

[Locations of test holes are shown in fig. 7]

\begin{tabular}{|c|c|c|c|c|}
\hline \multirow[b]{2}{*}{$\begin{array}{c}\text { land surface in } \\
\text { meters }\end{array}$} & \multicolumn{4}{|c|}{ Percent of grain size } \\
\hline & $\begin{array}{c}\text { Gravel } \\
(2-64 \mathrm{~mm})\end{array}$ & $\begin{array}{c}\text { Sand } \\
(0.625-2 \mathrm{~mm})\end{array}$ & $\begin{array}{c}\text { Silt } \\
(0.004-0.625 \mathrm{~mm}) \\
\end{array}$ & $\begin{array}{c}\text { Clay } \\
(<0.004 \mathrm{~mm}) \\
\end{array}$ \\
\hline \multicolumn{5}{|c|}{ Core samples of till 1} \\
\hline 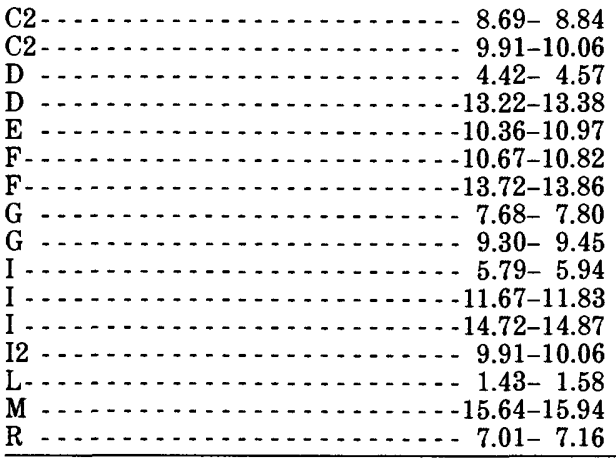 & $\begin{array}{r}9.7 \\
7.3 \\
11.0 \\
3.5 \\
28.4 \\
8.5 \\
6.4 \\
25.4 \\
11.0 \\
21.7 \\
2.7 \\
5.9 \\
2.5 \\
7.7 \\
10.7 \\
9.4\end{array}$ & $\begin{array}{r}24.9 \\
12.3 \\
11.5 \\
28.5 \\
7.1 \\
13.8 \\
6.9 \\
21.3 \\
10.6 \\
18.3 \\
4.5 \\
9.9 \\
5.6 \\
10.8 \\
9.8 \\
11.8\end{array}$ & $\begin{array}{l}34.8 \\
28.2 \\
32.2 \\
22.3 \\
21.5 \\
28.9 \\
27.9 \\
25.9 \\
25.0 \\
24.6 \\
28.0 \\
26.3 \\
21.3 \\
25.3 \\
26.6 \\
28.2 \\
\end{array}$ & $\begin{array}{l}30.7 \\
52.2 \\
45.3 \\
45.7 \\
43.0 \\
48.8 \\
58.8 \\
27.4 \\
53.4 \\
35.4 \\
64.8 \\
57.9 \\
70.7 \\
56.2 \\
52.9 \\
50.6 \\
\end{array}$ \\
\hline \multicolumn{5}{|c|}{ Core samples of disturbed materials within the till } \\
\hline 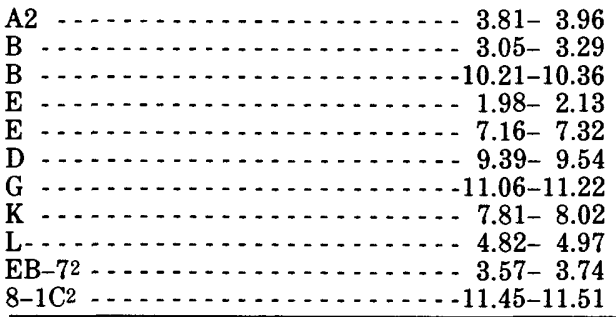 & $\begin{array}{r}1.4 \\
42.6 \\
14.8 \\
34.6 \\
0.0 \\
1.6 \\
0.0 \\
71.4 \\
7.7 \\
0.1 \\
0.0\end{array}$ & $\begin{array}{r}35.3 \\
15.5 \\
8.7 \\
31.4 \\
1.9 \\
5.6 \\
0.9 \\
2.2 \\
10.8 \\
49.2 \\
13.7\end{array}$ & $\begin{array}{r}30.2 \\
19.4 \\
53.7 \\
24.9 \\
28.0 \\
33.8 \\
28.1 \\
8.5 \\
25.3 \\
46.0 \\
77.9\end{array}$ & $\begin{array}{r}33.3 \\
22.5 \\
22.8 \\
8.5 \\
70.0 \\
59.0 \\
70.7 \\
17.9 \\
56.2 \\
4.7 \\
8.4\end{array}$ \\
\hline
\end{tabular}

1Mean percent of grain size for core samples of till are for gravel, 10.7; sand, 13.0; silt, 26.7; and clay, 49.6. Standard deviation in percent of grain size for core samples of till is for gravel, 7.8; sand, 6.9; silt, 3.6; and clay, 11.7.

2Samples analyzed by Dunn Geoscience Laboratory, Latham, New York; otherwise samples were analyzed by the Hydrologic Laboratory, Denver, Colorado.

TABLE 6.-Mineral composition of selected core samples 1

[All values are in weight percent; locations of test holes are shown in fig. 7]

\begin{tabular}{|c|c|c|c|c|c|c|c|c|c|c|}
\hline \multirow[b]{3}{*}{ Minerals } & \multicolumn{10}{|c|}{ Test-hole identification symbol, depth interval2, and material } \\
\hline & $\begin{array}{c}\mathrm{F} \\
6.8 \\
7.0 \\
\end{array}$ & $\begin{array}{c}13 \\
2.3 \\
2.4 \\
\end{array}$ & $\begin{array}{c}\mathrm{J} \\
16.1 \\
16.2 \\
\end{array}$ & $\begin{array}{c}\mathrm{N} \\
7.5 \\
7.6 \\
\end{array}$ & $\begin{array}{l}\mathrm{C} 2 \\
2.9 \\
3.0 \\
\end{array}$ & $\begin{array}{c}\mathrm{C} 2 \\
13.0 \\
13.1 \\
\end{array}$ & $\begin{array}{c}\mathrm{D} \\
4.3 \\
4.4 \\
\end{array}$ & $\begin{array}{c}\mathrm{D} \\
9.1 \\
9.2 \\
\end{array}$ & $\begin{array}{c}\mathrm{G} \\
11.0 \\
11.2 \\
\end{array}$ & $\begin{array}{c}\mathrm{L} \\
4.7 \\
4.8 \\
\end{array}$ \\
\hline & Till & $\begin{array}{c}\text { Oxidized } \\
\text { till }\end{array}$ & Till & Till & $\begin{array}{c}\text { Oxidize } \\
\text { till }\end{array}$ & Till & Till & Lakebeds & Lakebeds & Lakebeds \\
\hline 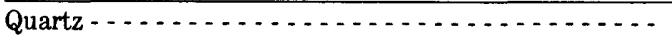 & 24 & 24 & 24 & 22 & 26 & 22 & 27 & 32 & 23 & 33 \\
\hline Potassium feldspar $\ldots \ldots \ldots \ldots$ & 1 & $<1$ & $<1$ & 1 & 2 & 1 & 1 & 3 & 0 & 3 \\
\hline Plagioclase feldspar $\ldots \ldots \ldots \ldots \ldots$ & 7 & 7 & 5 & 4 & $\overline{7}$ & 5 & 5 & 9 & 6 & 10 \\
\hline Calcite $\ldots \ldots \ldots \ldots \ldots$ & 11 & $\dot{7}$ & 7 & 8 & 9 & 7 & 9 & 11 & 7 & 9 \\
\hline 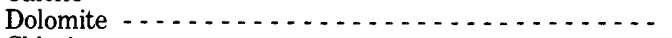 & 5 & 3 & $\dot{5}$ & 5 & 7 & 5 & 5 & 9 & $\dot{5}$ & 11 \\
\hline 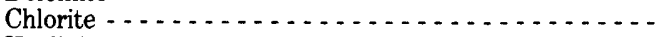 & 3 & 0 & 4 & 4 & 1 & 12 & 5 & 4 & 6 & 4 \\
\hline 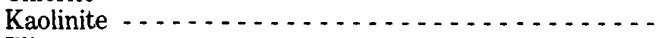 & 9 & 9 & 10 & 9 & 7 & 0 & 9 & 6 & 8 & 5 \\
\hline 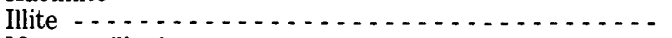 & 24 & 27 & 27 & 21 & 28 & 26 & 30 & 16 & 19 & 15 \\
\hline Montmorillonite $\ldots \ldots \ldots \ldots$ & 0 & $<1$ & 0 & 0 & 0 & 0 & 0 & 0 & 0 & 0 \\
\hline Mixed-layer clay minerals $\ldots \ldots \ldots$ & 4 & 9 & 4 & 6 & 4 & 1 & $<1$ & 4 & 7 & 5 \\
\hline Totals $\ldots \ldots \ldots \ldots$ & 88 & 86 & 86 & 80 & 91 & 79 & 91 & 94 & 81 & 95 \\
\hline
\end{tabular}

1 From LaFleur (1979, table 1). Mineral composition determined by B. J. Anderson, U.S. Geological Survey; X-ray diffraction according to method of Schultz (1964). Totals between 90 and 105 percent are considered normal for this semiquantitative method. Low totals in some samples probably indicate a higher iron content; the fluorescent radiation produced by iron causes loss of peak intensity and therefore generally lower percentages (B. J. Anderson, written commun., 1978).

2 Depths are in meters below land surface. 
two values reported by Fickies and others, 1979) averaged $5.4 \times 10^{-8} \mathrm{~cm} / \mathrm{s}$. Individual values from laboratory tests are listed in table 8.

Laboratory tests (four consolidation tests and two falling head tests) were run on six core samples of till to determine the effects of increased confining pressures

\section{TABLE 7.-Results of slug tests for hydraulic conductivity at piezometers finished in unoxidized till 1}

[Test hole locations are shown in figure 7; conductivity values are in centimeters per second]

\begin{tabular}{|c|c|c|c|c|}
\hline \multirow{2}{*}{$\begin{array}{l}\text { Test } \\
\text { hole }\end{array}$} & \multirow{2}{*}{$\begin{array}{c}\text { Piezometer } \\
\text { number }\end{array}$} & \multirow{2}{*}{$\begin{array}{c}\text { Depth below } \\
\text { land surface } \\
\text { (meters) }\end{array}$} & \multicolumn{2}{|c|}{ Hydraulic conductivity } \\
\hline & & & Hvorslev method 2 & Cooper method 3 \\
\hline $\mathrm{C} 2-$ & $\cdots-2$ & $11.7-12.3$ & $1 \times 10^{-8}$ & $5 \times 10^{-8}$ \\
\hline$E \cdots$ & $\cdots-3$ & $14.1-14.7$ & $3 \times 10-8$ & $10 \times 10^{-8}$ \\
\hline $\mathrm{F} \ldots$ & $-\ldots 3$ & $15.5-16.2$ & $3 \times 10^{-8}$ & $9 \times 10^{-8}$ \\
\hline $\mathrm{G}$ & $\cdots-2$ & $7.5-8.1$ & $2 \times 10^{-8}$ & $5 \times 10^{-8}$ \\
\hline $\mathrm{G}-$ & $\ldots-3$ & $12.3-12.9$ & $2 \times 10^{-8}$ & $6 \times 10^{-8}$ \\
\hline $\mathrm{J} 2-$ & $\cdots 1$ & $5.4-5.8$ & $2 \times 10^{-8}$ & $6 \times 10^{-8}$ \\
\hline K - & $\ldots 3$ & $14.6-15.2$ & $2 \times 10^{-8}$ & $4 \times 10^{-8}$ \\
\hline $\mathbf{M} \cdot$ & -2 & $15.3-15.9$ & $2 \times 10^{-8}$ & $8 \times 10^{-8}$ \\
\hline $\mathrm{P}-\cdots$ & --2 & $13.8-14.4$ & $2 \times 10^{-8}$ & $6 \times 10^{-8}$ \\
\hline S - - & $-\cdots 1$ & $4.0-4.6$ & $2 \times 10^{-8}$ & $4 \times 10^{-8}$ \\
\hline $5-2 \mathrm{D}$ & $\cdots 1$ & $11.6-11.9$ & $2 \times 10^{-8}$ & $6 \times 10^{-8}$ \\
\hline \multirow{2}{*}{\multicolumn{2}{|c|}{$R \ldots \ldots-\cdots 2$}} & $7.1-7.6$ & $2 \times 10^{-8}$ & $5 \times 10^{-8}$ \\
\hline & & \multicolumn{2}{|c|}{ Mean value } & $6 \times 10^{-8}$ \\
\hline
\end{tabular}

1 From Prudic, 1982.

2 M. J. Hvorslev, 1951; flow is assumed spherical.

3 H. H. Cooper, and others, 1967; flow is assumed horizontal. on hydraulic conductivity (Prudic, 1982). In general, vertical conductivity decreased about 40 percent as confining pressures increased from near atmospheric to 7 $\mathrm{kg} / \mathrm{cm}^{2}$ (a pressure equivalent to a depth of $30 \mathrm{~m}$ ), which suggests that increased overburden pressure reduces the hydraulic conductivity. About half of this decrease occurred between confining pressures near atmospheric and $1 \mathrm{~kg} / \mathrm{cm}^{2}$. At pressures between 1 and $7 \mathrm{~kg} / \mathrm{cm}^{2}$, vertical conductivity decreased linearly (Prudic, 1982, fig. 6).

Five core samples were tested with water of chemical composition similar to that in the trenches to determine its effect on hydraulic conductivity. Three samples showed a threefold to sevenfold decrease when compared to values previously obtained from tests with formation water; the other two showed little or no change. These results suggest that geochemical reactions between trench water and the till may reduce the hydraulic conductivity to varying degrees.

A curve relating soil-moisture content to soil-moisture tension under unsaturated conditions was calculated from mercury porosimeter tests (Prudic, 1981), and ratios of hydraulic conductivity of unsaturated till to that of saturated till over a range of soil-moisture ten-

TABLE 8.-Results of laboratory tests for hydraulic conductivity of core samples from the unoxidized till.

[Locations of test holes are shown in figure 7; conductivity values are in centimeters per second]

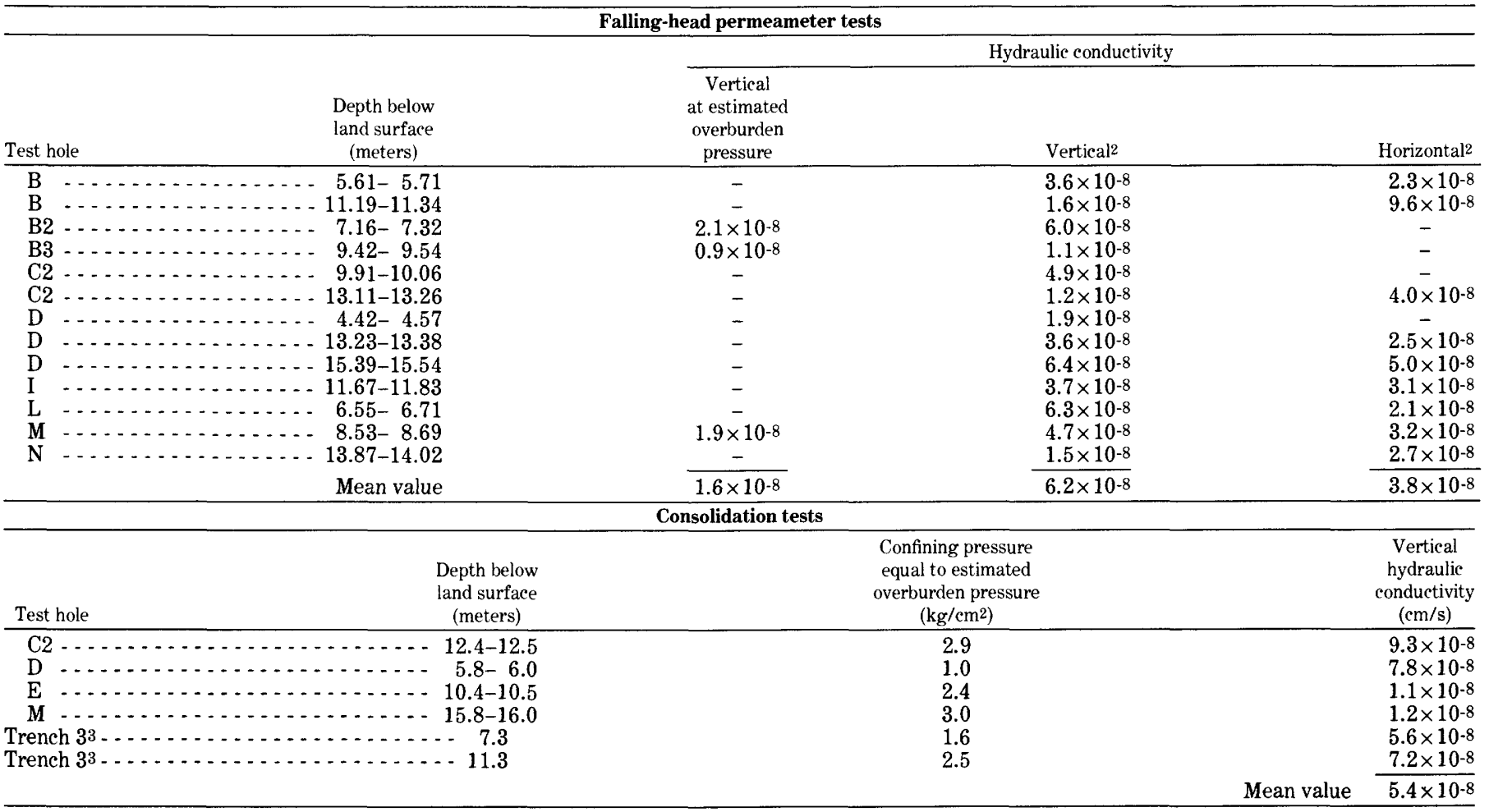

1 From Prudic, $1982 ;$ - means values of hydraulic conductivity not determined.

2 No confining pressures applied.

3 Trench 3 is a research trench exavated by the New York State Geological Survey $215 \mathrm{~m}$ east of test hole N (Fickies and others, 1979). Hydraulic conductivity at estimated overburden pressure linearly extrapolated between load increments. 
sions were calculated from the soil-moisture content versus soil-moisture-tension curves with an equation by Millington and Quirk (1961). Curves of soil-moisture content and hydraulic-conductivity ratios plotted against soil-moisture tension, as determined from seven mercury-porosimeter tests, are shown in figure 11.

\section{ANISOTROPY}

Fickies and others (1979) reported anisotropy of 35:1 (horizontal hydraulic conductivity greater than vertical) from laboratory tests of two samples of saturated till. However, when nine samples of the till cored from test holes were tested for vertical and horizontal conductivity, results did not suggest anisotropy (Prudic, 1982). Examination of 18 thin sections of till prepared from other core samples showed no preferential horizontal layering of the clay grains (LaFleur, written commun., 1980), which also suggests little anisotropy. Thus, the till is not strongly anisotropic and, on the basis of field and laboratory tests, the range in vertical and horizontal hydraulic conductivity of the till is between $2 \times 10^{-8}$ $\mathrm{cm} / \mathrm{s}$ to $6 \times 10^{-8} \mathrm{~cm} / \mathrm{s}$.

\section{FRACTURED ZONE}

Cores from test holes near the burial site revealed that the upper 2 to $3 \mathrm{~m}$ of till is oxidized to medium brown and contains abundant intersecting fractures and that fractures having firm oxidized borders a few millimeters wide extend downward into the plastic unoxidized till to depths of about $4.5 \mathrm{~m}$ (Prudic and Randall, 1979). Dana and others (1979, p. 14) described in detail the nature, orientation, and spacing of fractures in the walls of a research trench $200 \mathrm{~m}$ from the burial ground; they also noted that oxidized fractures decreased in number and width with depth and were absent below about $5 \mathrm{~m}$.

The oxidized zones bordering the fractures, as well as thin coatings of manganese or iron oxide or calcite, root hairs, and thin gray (reduced) zones on the inner surfaces of some fractures, clearly suggest water movement along the fractures. The hydraulic conductivity calculated from slug tests of three shallow piezometers (H-1, J4-1, and U-1, which were $3 \mathrm{~m}$ or less in depth) ranged from that of the unoxidized till to a value 200 times greater. Grisak and Cherry (1975) showed that fractures significantly increased the permeability of till at a site in Canada. Trial computer simulations of ground-water flow in the till (described later) indicate that the upper, weathered till is as much as 10 times more permeable than the unweathered till (below 5-m depth), presumably because of the fractures.

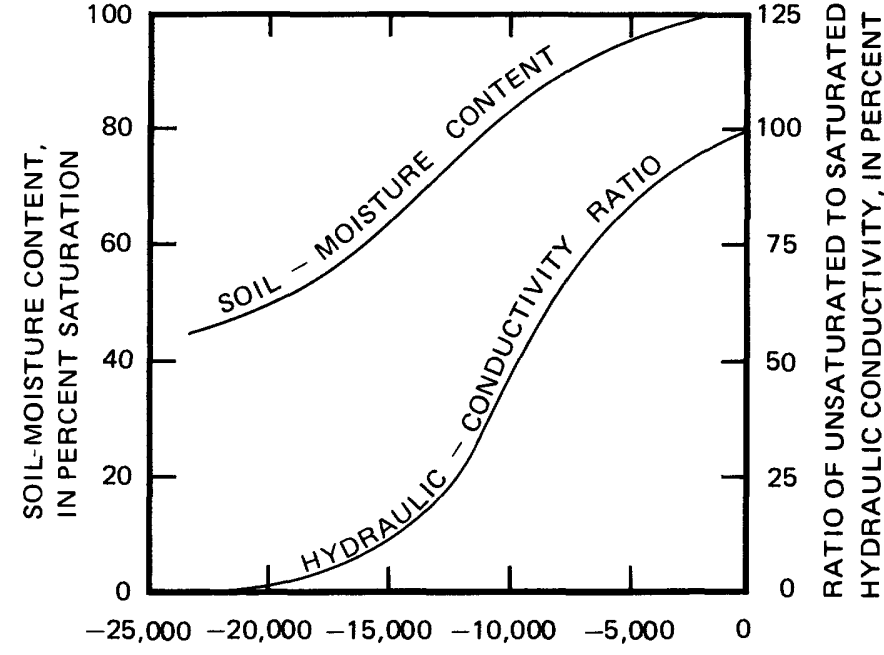

PRESSURE HEAD, IN CENTIMETERS OF WATER

FIGURE 11.-Relation of hydraulic conductivity and volumetric soilmoisture content to soil-moisture tension, as calculated from seven mercury-porosimeter tests of till (from Prudic, 1981).

\section{LENSES OF SORTED MATERIAL}

\section{EXTENT AND CONTINUITY}

The till in which the trenches are excavated contains scattered, distorted lenses of stratified sediments that constitute about 7 percent of the total mass and also contains locally abundant wisps of silt. As explained in table 4 , all of the larger lenses observed in trench excavations were discontinuous, deformed, and rotated to random orientations. Several vertical sections (fig. 12) illustrate the lithology and distribution of stratified lenses near the trenches. Differences in altitude and lithology of stratified materials, and the steep dip of some lenses, commonly preclude correlation and thus rule out the possibility of a continuous stratigraphic unit of waterlaid sediment. The difference between materials penetrated by holes I and I3 (fig. 12C), less than $2 \mathrm{~m}$ apart, suggests that even over the interval of $2 \mathrm{~m}$, the correlation of stratified units within the till is tenuous.

Borehole logs from three localities near the trenches indicated a possibility that lenses of fine sand, silt, and clay 10 to $100 \mathrm{~m}$ in extent might be present within the till. Assessments of conditions at each of these localities follow:

1. Test holes 4-4A, F, 5-2D, D, and E (fig.12C, D) penetrated 60 to $120 \mathrm{~cm}$ of silt and clay with subordinate fine sands between altitudes of 411 and 414 $\mathrm{m}$. However, bedding dips of $20^{\circ}$ to $45^{\circ}$ and abundant internal deformation in individual cores, as well as differences in stratigraphic details, argue against their continuity as a single layer. Other holes confirm that these materials are not con- 

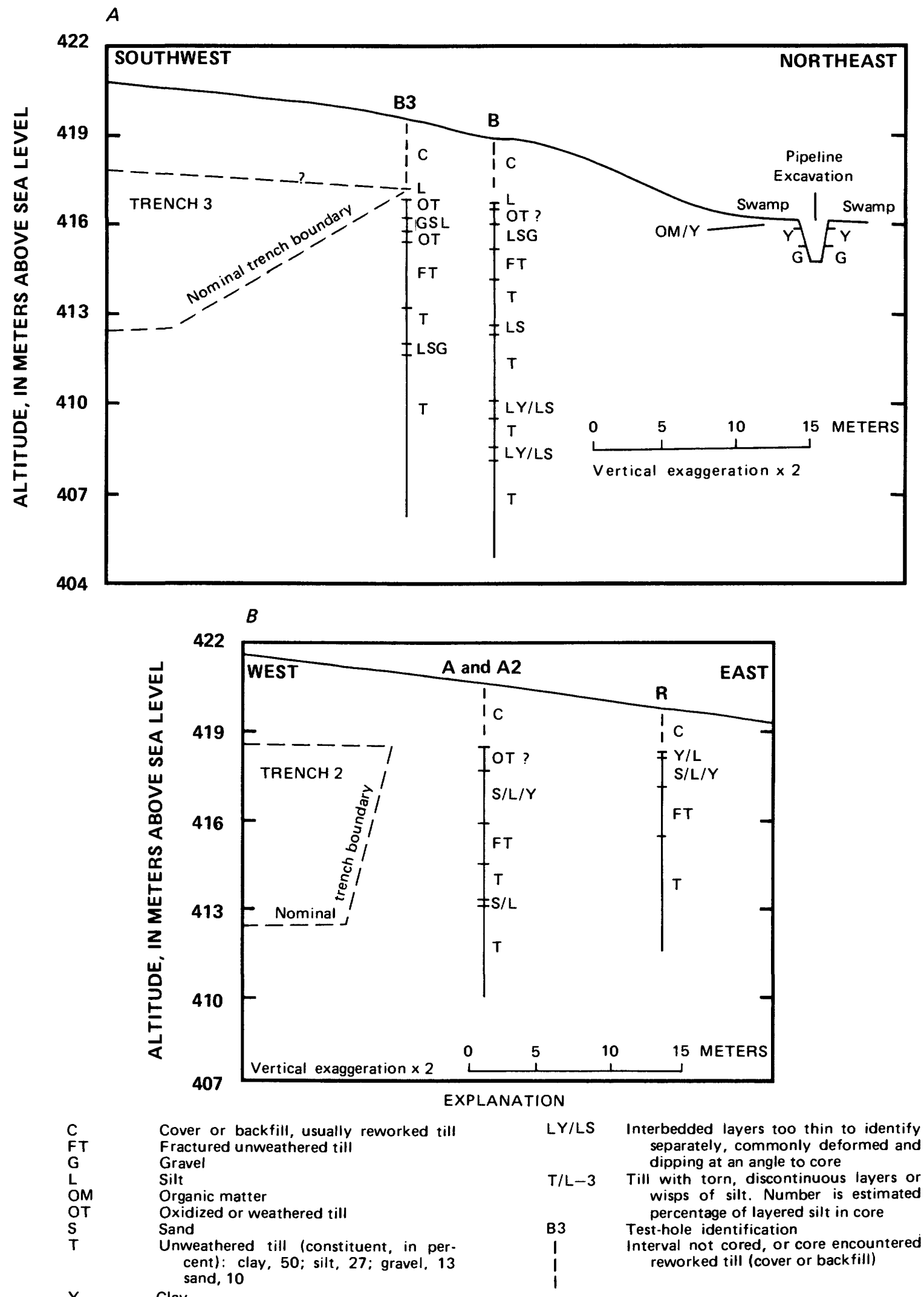

$Y \quad$ Clay

LS, LY, Mixed materials with increasing abun-

SG, etc. $\quad$ dance from left to right; for example, LS is silty sand

FIGURE 12.-Distribution of sorted material in till at waste-burial site. Location of all sections is shown in figure $12 I$. $A$, Test hole B3 to swamp northeast of burial site. B, Trench 2 to test hole R. 
C
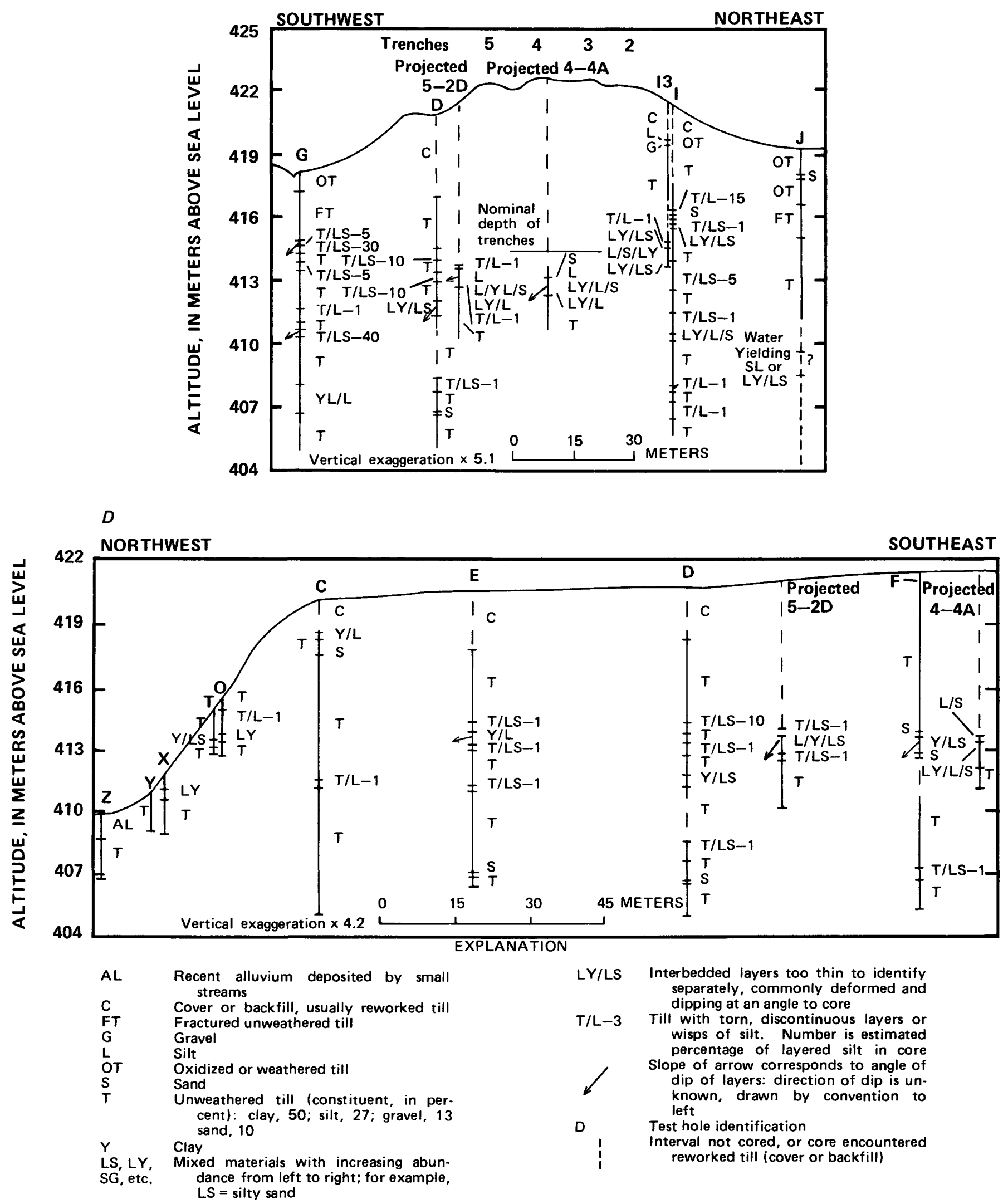

FIGURE 12.-Continued. Distribution of sorted material at waste-burial site. $C$, Test holes G to J, perpendicular to north trenches. $D$, Test holes $\mathrm{F}$ to $\mathrm{Z}$, parallel to trench 5 (Location of sections is shown in figure $12 I$ ). 


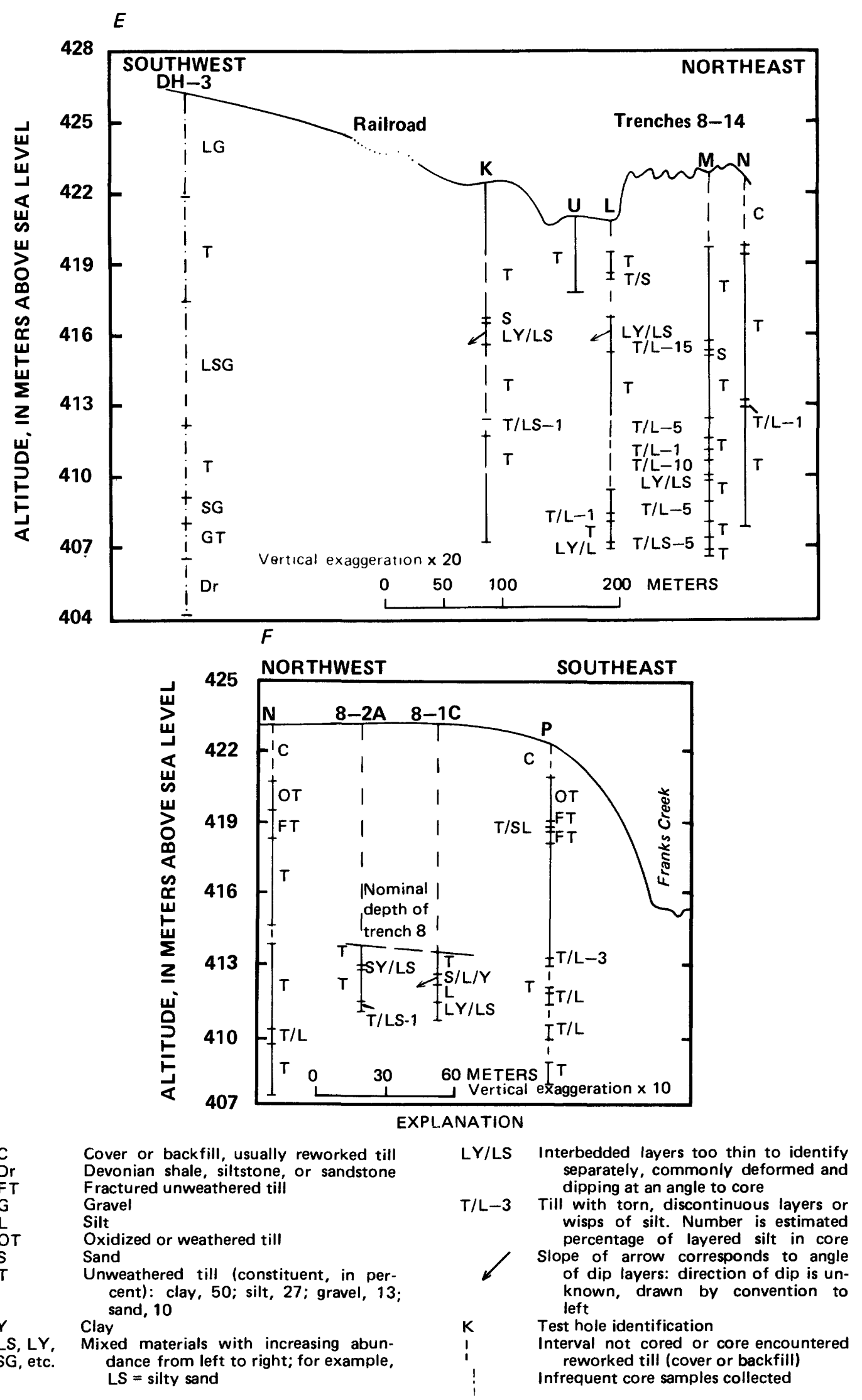

FIGURE 12.-Continued. Distribution of sorted material in till at waste-burial site. $E$, Test holes DH-3 to $\mathrm{N}$, perpendicular to south trenches. $F$, Test holes $\mathrm{N}$ to $\mathrm{P}$, parallel to trench 8 . (Location of sections is shown in figure $12 I$.) 


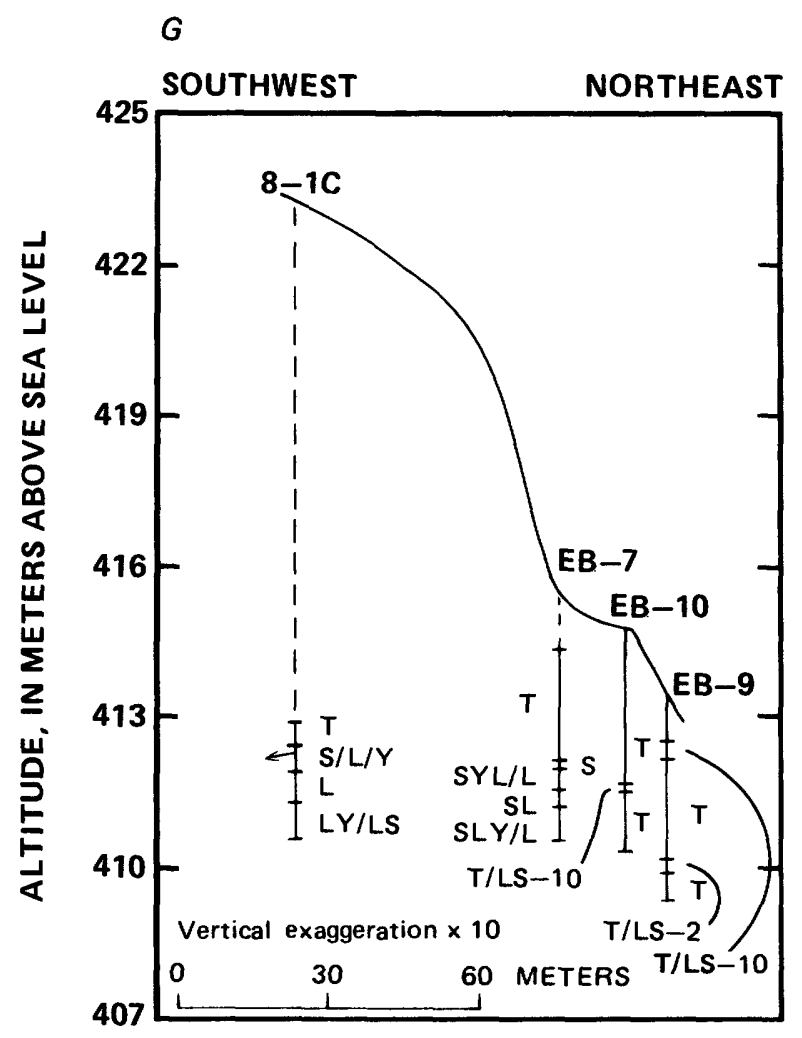

H

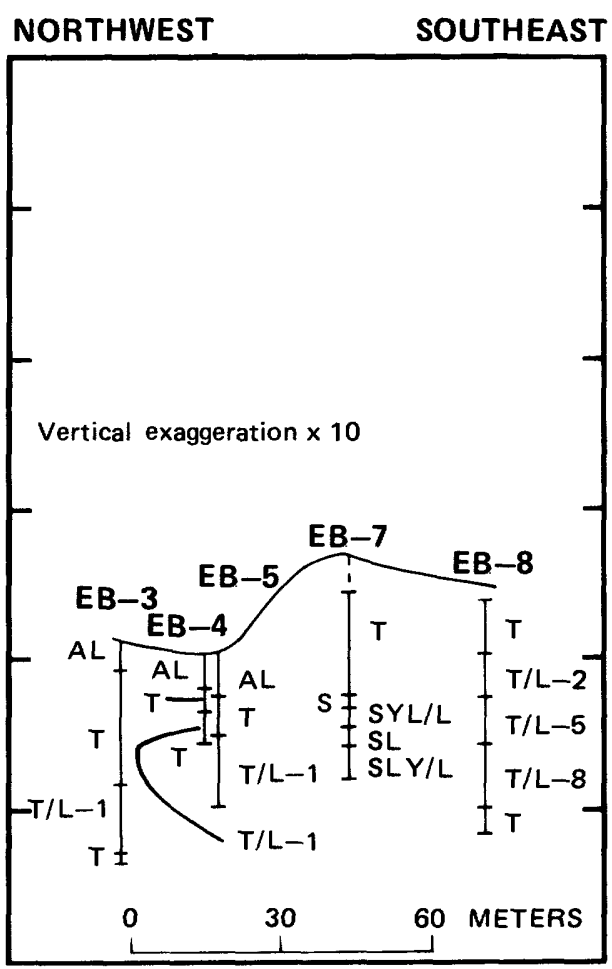

EXPLANATION

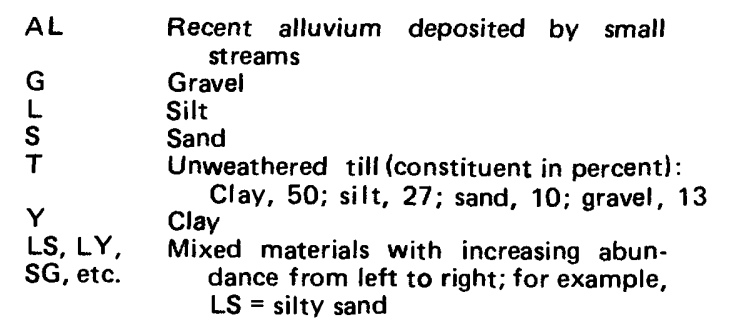
LY/LS Interbedded layer too thin to identify separately, commonly deformed and dipping at an angle to core
Slope of arrows corresponds to angle of dip of layers; direction of dip is unknown, drawn by convention to left
$T / L-3$ Till with torn, discontinuous layers or wisps of silt. Number is estimated percentage of layered silt in core.
EB-7 Test hole identification
I Interval not cored or core encountered reworked till (cover or backfill)

FIGURE 12.-Continued. Distribution of sorted material in till at waste-burial site. G, Test hole 8-1C east to Franks Creek. H, Test hole EB-3 south to test hole EB-8 along Franks Creek. (Location of sections is shown in figure 12I.)

tinuous as far north and west as Franks Creek tributaries.

2. Test hole 8-1C penetrated almost $2 \mathrm{~m}$ of layered silt, fine sand, and clay at $411 \mathrm{~m}$ altitude immediately beneath the floor of trench 8 . Test holes to the north and south penetrated different materials (fig. $12 F$ ), but test hole EB-7, $50 \mathrm{~m}$ to the east, penetrated a similar section at the same altitude (fig. $12 G$ ). It is possible that layered lacustrine materials are continuous between these two holes, but they do not continue far north, east, or south of hole EB-7, as indicated by several holes in figs. $12 G$ and $12 H$, nor do they conduct water from trench 8 toward Franks Creek. The water level in a piezometer finished in the silt in hole EB-7 was consistently about $1 \mathrm{~m}$ higher than in hole 8-1C.
Test hole EB-8 (fig. 12H) penetrated abundant, grossly deformed, torn fragments of silt that could not possibly constitute an inplace layer. Thus, the lacustrine materials in test holes 8-1C and EB-7 probably are isolated pods.

3. Rhythmic fine sand, silt, and clay $1.5 \mathrm{~m}$ thick was penetrated at or near pre-trench land surface in three test holes $7 \mathrm{~m}$ apart east of trench 2 (test holes A, A2, and R). Proximity and similar lithology suggest that the lacustrine material may be continuous and intersect trench 2 (fig. 12B); however, this is not certain because contacts between the lacustrine sediment and till at angles of $60^{\circ}$ to $90^{\circ}$ were observed in cores from both holes. If the lacustrine sediment is continuous, the apparent dip is toward the trench (fig. 12B), and the 


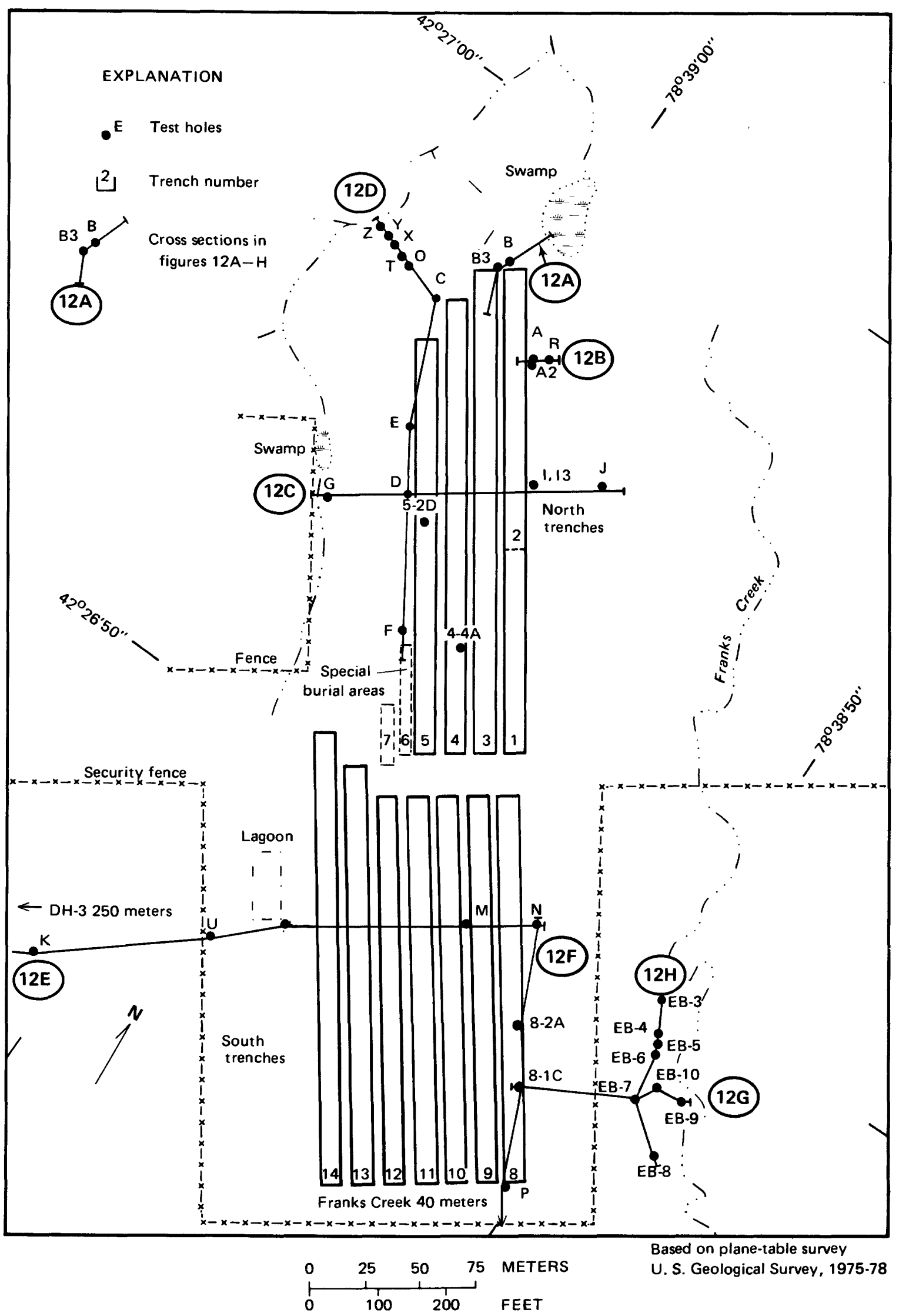

FIGURE 12.-Continued. $I$, Location of sections depicted in figures $12 \mathrm{~A}-12 \mathrm{H}$. 
hydraulic head in piezometers R-1 and A2-1, finished in the disturbed lacustrine unit, is above trenchwater level. This indicates that the lens has not served as a conduit for outward migration of trench water but rather may be a conduit for slow lateral flow to trench 2 .

Over much of Buttermilk Creek valley, the till is mantled by a few meters of gravel deposited by local streams in late-glacial or postglacial time (unit 4, table 4). This gravel is missing near the burial ground except in two small, low-lying areas described below:

1. In 1977, a meter of organic and inorganic silty clay underlain by a meter of gravel was observed beneath a shallow depression that collects runoff north of trench 2 , along a gas-pipeline excavation. Test holes B and B3, drilled where the edge of the trench cover approaches or overlaps the shallow depression (fig. 12A), penetrated silty gravel (test hole B) and gravelly silts (test hole B3) at the same altitude as the gravel beneath the shallow depression. The gravel was overlain by about a meter of till (test hole B3) or possibly colluvium (test hole $B)$. The water level in a piezometer finished next to the gravel at test hole $B$ ranged seasonally from slightly above the surface of the shallow depression to $50 \mathrm{~cm}$ below it, further suggesting continuity. If the gravel beneath the shallow depression does not extend south to test hole B3, the overlying till might have slid onto an early postglacial flood plain from adjacent, slightly higher ground. Alternatively, the gravels at test holes B and B3 may constitute remnants of ice-frontal deposits buried by a last brief ice readvance. If the gravel is continuous from test hole B3 to the nearby shallow surface depression and intersects trench 3 , it is possible that radionuclides could migrate along the gravel lenses once the water level in trench 3 exceeded an altitude of $416.5 \mathrm{~m}$.

2. According to Nuclear Fuel Services (written commun., 1974), a gravel lens as much as $1 \mathrm{~m}$ thick was observed during excavation of trench 13; the lens was just below land surface about $50 \mathrm{~m}$ north of the south end of the trench. Test pits penetrated gravelly material southwestward for about $60 \mathrm{~m}$, generally beneath 30 to $120 \mathrm{~cm}$ of till described as silty. This distribution of gravel coincides with a swampy shallow depression on a 1960 topographic map. Perhaps the depression was occupied briefly by a late-glacial stream and later trapped silty alluvium or colluvium and was then backfilled with till after removal of topsoil and muck by the site operator in 1970 (A. Bockleman, Nuclear Fuels Services, oral commun., 1975). If the water level in trench 13 were to rise to the top of the trench, it is possible that radionuclides could migrate along the gravel unit to trench 14. Similarly, if the water level in trench 14 were to rise close to the top of the trench, radionuclides could possibly migrate to trench 13 or southwestward several meters. However, the gravel unit does not seem to intersect the slope of Franks Creek but rather is contained in a shallow depression (now obscured by the trenches). Thus, the migration of radionuclides through the gravel to some discharge point at land surface seems unlikely.

\section{HYDRAULIC CONDUCTIVITY}

Slug tests of five piezometers (D-1, E-2, I2-1, J-1, and $\mathrm{K}-2$ ) finished in small lenses of silt, sand, and rarely gravel were analyzed for hydraulic conductivity by the methods of Hvorslev (1951) and Cooper and others (1967). The average hydraulic conductivity obtained by the Hvorslev method was $3 \times 10^{-6} \mathrm{~cm} / \mathrm{s}$; the average value from the method of Cooper and others was $6 \times 0^{-6}$ $\mathrm{cm} / \mathrm{s}$. Values from these tests ranged more widely than those of the till and are presented in table 9. The average hydraulic conductivity of the sorted material in the till probably lies between the mean values from these two methods-two orders of magnitude higher than that of the till itself.

\section{EQUIVALENT HYDRAULIC CONDUGTIVITY OF THE TILL}

The equivalent hydraulic conductivity of the till unit may be determined as a weighted average of the hydraulic conductivity of the till itself and the hydraulic conductivity of the randomly distributed pods or lenses of silt, sand, and rarely gravel. An initial estimate, calculated by simple proportions, was about $1 \times 10^{-7}$ $\mathrm{cm} / \mathrm{s}$ (Prudic and Randall, 1979). Prudic (1981) reported a slightly lower value of $8 \times 10^{-8} \mathrm{~cm} / \mathrm{s}$, on the basis of

TABLE 9.-Results of slug tests for hydraulic conductivity at piezometers finished in lenses of sorted materials 1

[Test hole locations are shown in figure 7]

\begin{tabular}{|c|c|c|c|c|}
\hline \multirow{2}{*}{$\begin{array}{l}\text { Test } \\
\text { hole }\end{array}$} & \multirow{2}{*}{$\begin{array}{l}\text { Piezometer } \\
\text { number }\end{array}$} & \multirow{2}{*}{$\begin{array}{l}\text { Depth below } \\
\text { land surface } \\
\text { (meters) }\end{array}$} & \multicolumn{2}{|c|}{$\begin{array}{c}\text { Hydraulic conductivity } \\
\text { (in centimeters per second) }\end{array}$} \\
\hline & & & Hvorslev method2 & Cooper method 3 \\
\hline $\mathrm{D}-$ & $\cdots 1$ & $8.8-9.8$ & $1 \times 10^{-6}$ & $2 \times 10^{-6}$ \\
\hline $\mathrm{E}$ & $\ldots-2$ & $6.6-7.5$ & $2 \times 10-6$ & $4 \times 10^{-6}$ \\
\hline & $\cdots 1$ & $10.1-11.0$ & $2 \times 10-7$ & $3 \times 10^{-7}$ \\
\hline $\mathrm{J} \ldots$ & $\ldots 1$ & $10.2-10.9$ & $1 \times 10^{-5}$ & $2 \times 10^{-5}$ \\
\hline \multirow[t]{2}{*}{$\mathrm{K}$} & $\cdots 2$ & $5.9-6.5$ & $8 \times 10^{-7}$ & $3 \times 10^{-6}$ \\
\hline & & Mean value & $3 \times 10^{-6}$ & $6 \times 10^{-6}$ \\
\hline
\end{tabular}

1 From Prudic, 1982.

2 M. J. Hvorslev, 1951; flow is assumed spherical.

3 H. H. Cooper and others, 1967; flow is assumed horizontal. 
a lower estimate of hydraulic conductivity of both the till and the sorted material. However, because the lenses of sorted material are surrounded by till and because the general flow patterns are perpendicular to the changes in the hydraulic conductivities, the best means of averaging the hydraulic conductivity of the till and the lenses of sorted material is expressed in the following equation (Freeze and Cherry, 1979, p. 34):

$$
K=\frac{d}{\frac{d_{1}}{K_{1}}+\frac{d_{2}}{K_{2}}+\ldots+\frac{d_{n}}{K_{n}}}
$$

where

$$
\begin{aligned}
K= & \begin{array}{l}
\text { equivalent hydraulic conductivity, } \\
L T^{-1} ;
\end{array} \\
K_{1}, K_{2}, K_{n}= & \begin{array}{l}
\text { hydraulic conductivity of individual } \\
\text { units, } L T^{-1} ;
\end{array} \\
d= & \text { total thickness, } L ; \text { and } \\
d_{1}, d_{2}, d_{n}= & \text { thickness of individual units, } L .
\end{aligned}
$$

Thus, the equivalent hydraulic conductivity of the till was computed as follows: $K_{1}$ was taken to be the average hydraulic conductivity of the unweathered till, which is between $2 \times 10^{-8} \mathrm{~cm} / \mathrm{s}$, and $6 \times 10^{-8} \mathrm{~cm} / \mathrm{s}$, and $K_{2}$ to be the average hydraulic conductivity of the sorted material, which is probably between $3 \times 10^{-6}$ and $6 \times 10^{-6} \mathrm{~cm} / \mathrm{s}$. The basis for these values was explained on the preceding pages. Thickness of the sorted material $\left(d_{2}\right)$ was taken as 7 percent of the total thickness $(d)$ (Prudic and Randall, 1979). Substituting these values into equation 1 yielded an equivalent hydraulic conductivity of the till between $2.2 . \times 10^{-8} \mathrm{~cm} / \mathrm{s}$ and $6.4 \times 10^{-8}$ $\mathrm{cm} / \mathrm{s}$, essentially equal to the hydraulic conductivity of the till itself. A reasonable equivalent value is probably $4 \times 10^{-8} \mathrm{~cm} / \mathrm{s} \pm 2 \times 10^{-8} \mathrm{~cm} / \mathrm{s}$. The equivalent hydraulic conductivity of the till between $2 \times 10^{-8} \mathrm{~cm} / \mathrm{s}$ and $6 \times 10^{-8} \mathrm{~cm} / \mathrm{s}$ was used in the simulation of groundwater flow and in the computation of rates of water movement.

\section{GROUND-WATER FLOW AT THE BURIAL SITE}

In general, ground water at the burial site flows vertically downward through the till and the unsaturated part of the underlying lacustrine sequence and laterally within the saturated part of the lacustrine sequence northeastward to points of discharge along Buttermilk Creek. Detailed discussions on the direction and rate of ground-water flow, including the simulation of ground-water flow with a computer model, are presented in the following sections.

\section{FLOW WITHIN THE TILL}

The hydraulic gradients in the till surrounding the burial site as determined from several nested piezometers is predominantly downward, even beneath adjacent small stream valleys, where localized discharge of ground water might be expected. Figure 13 shows the distribution of hydraulic heads along vertical sections perpendicular to the north and south trenches from measurements taken in February 1976. The position of the water table was estimated from the intersection of a line of equal hydraulic head with the altitude of an equivalent value (pressure head equal to zero). At that time, most of the north trenches (1-5) were nearly filled with water (as discussed in section "Recharge to the trenches"), whereas only the lowest part of each south trench (8-14) was saturated. In general, ground water flows from areas of higher hydraulic head to lower hydraulic head; thus, the direction of seepage from the trenches was mostly downward with some outward movement within a few meters of the trenches. A small flow component toward trench 5 may be inferred from the greater hydraulic head near land surface in test hole $\mathrm{D}, 3 \mathrm{~m}$ to the west.

Where data are sparse or absent, such as the area from test hole $\mathrm{N}$ eastward to Franks Creek (fig. 13), the distribution of hydraulic heads and the location of the water table can only be inferred. The till along the slopes of adjacent valleys is nearly saturated, as determined from hydraulic heads in shallow piezometers along the slopes of the adjacent valleys (test holes EB-1, EB-2, O, $\mathrm{T}, \mathrm{X}$, and $\mathrm{Y}$ in fig. 7). Thus, the till east of hole $\mathrm{N}$ is also probably saturated, although specific data are not available.

West of trench 14 , piezometers to depths of $14 \mathrm{~m}$ in test holes L and Q (figs. 7 and 13) never contained water after their installation in September and October 1975. This absence of positive pressure heads may be explained by a lack of infiltration because the upper soil layers were scraped away from the area between trench 14 and test hole U, leaving a smooth, sloping bare surface that sheds nearly all rainfall (Prudic and Randall, 1979). A few piezometers along the east side of the trenches, at depths of $8 \mathrm{~m}$ in test hole $\mathrm{N}$ (fig. 13) and 4 and $6 \mathrm{~m}$ in test hole I (fig. 13), have also been dry continuously or periodically, although occasional small positive heads were associated with seasonal changes or the addition of earth material near these test holes. These piezometers are also on relatively steep slopes that shed water readily. 

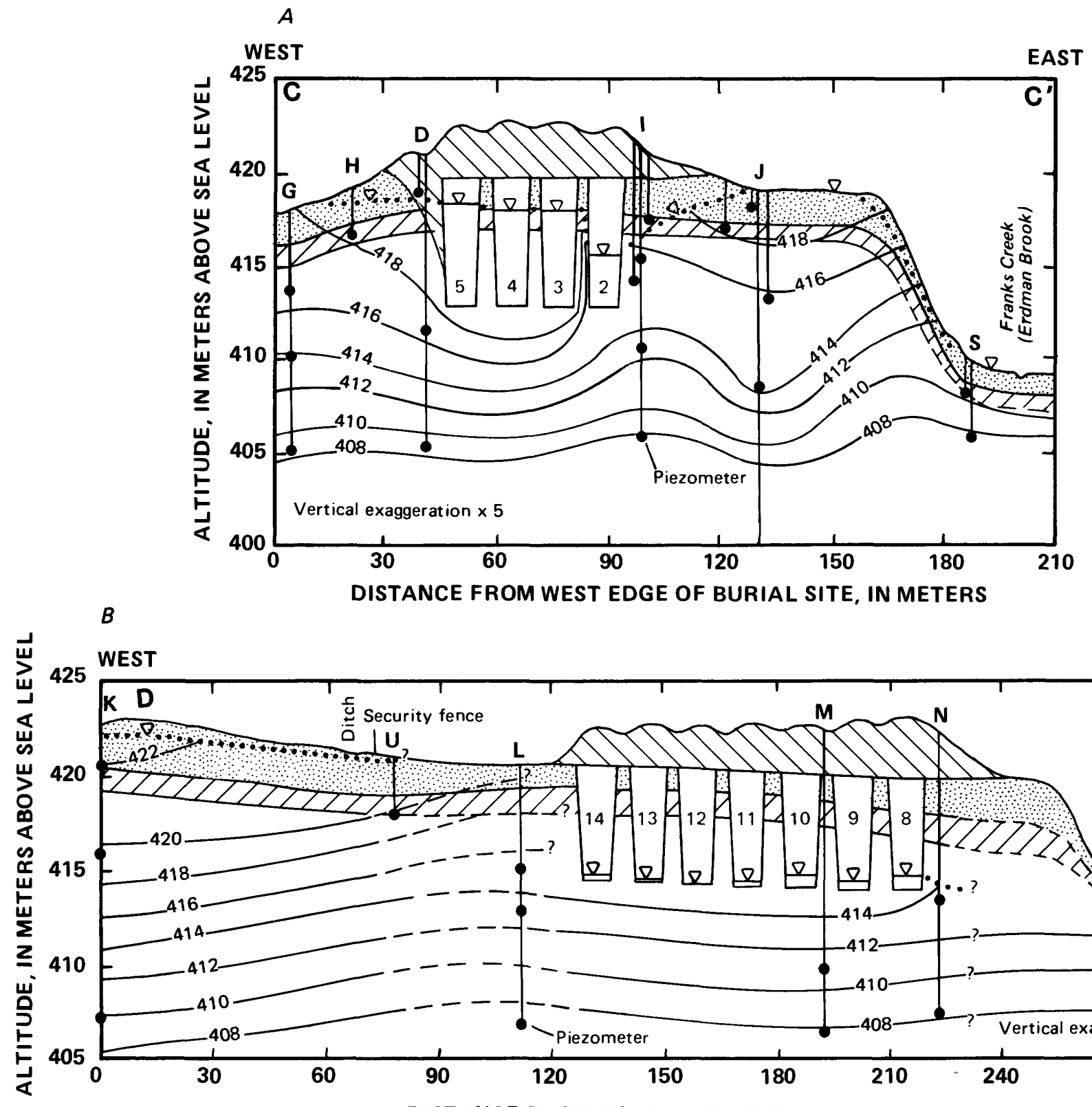

B
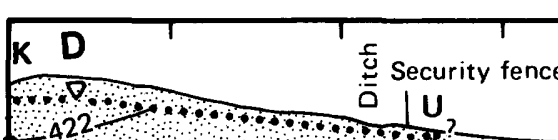
U
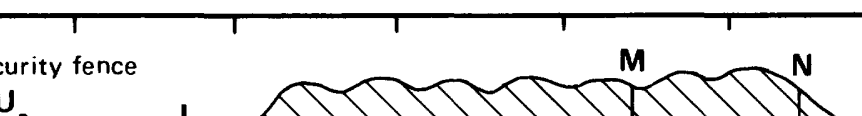

$D^{\prime}$

0
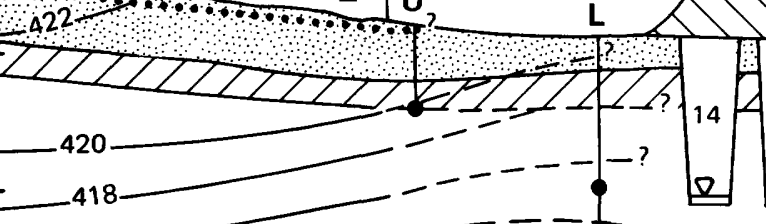

415

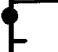

420

$418 \longrightarrow--\infty$
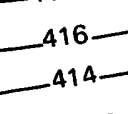

410

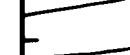

14

2_- -1

$\begin{array}{r}412+- \\ -410+-\end{array}-$

405

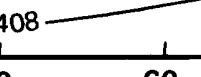

60

DISTANCE FROM HOLE K, IN METERS

EXPLANATION

$\square$ Backfill
Weathered till
$\square$ Till with oxidized fractures
$\square$ Unweathered till

$\nabla \quad$ Water level in trench

....... Assumed water table

$-414-$ Line of equipotential head

Interval 2 meters. Dashed where till may be unsaturated.

$\left.\right|^{M}$ Test hole

FIGURE 13.-Vertical sections through trenches showing head distribution during February 1976. $A$, Section C-C ${ }^{\prime}$ through north trenches. $B$, Section D-D' through south trenches. Location of sections is shown in figure 7 (from Prudic and Randall, 1979). 
Another explanation of the lack of positive pressure heads in piezometers in test holes $\mathrm{L}, \mathrm{Q}, \mathrm{N}$, and $\mathrm{I}$ is that the hydraulic conductivity may have been greater at these locations than elsewhere. This does not seem likely, however, because cores from test holes with piezometers having positive pressure heads did not differ greatly from those from test holes lacking positive pressures, and because piezometers along smoothsloping surfaces with low pressure heads did not consistently show higher hydraulic conductivity than those near shallow surface depressions. In addition, a lack of positive heads to depths of $14 \mathrm{~m}$ would require the hydraulic conductivity to be greater throughout entire thickness of the till, which seems unlikely.

Neutron-moisture profiles show little difference between the till near test hole $\mathrm{L}$ and the saturated till near test hole U (Prudic and Randall, 1979, p. 859). Three core samples of till from depths of 2 to $6 \mathrm{~m}$ near holes $\mathrm{L}$ and $\mathrm{Q}$ were analyzed for porosity and moisture content; results indicated the till to be at least 90 percent saturated. By comparison, similar tests indicated 80 to 112 percent saturation in five till samples from areas where piezometers demonstrated saturated conditions. Either the laboratory techniques were not precise (as in the case of 112 percent saturation) or some samples had dried slightly before they were analyzed. The till remains at least 90 percent saturated to suction pressures (negative pressure heads) of $5,000 \mathrm{~cm}$ as determined from a soil-moisture-tension curve (fig. 11) derived from mercury porosimeter tests. The till remains at least 60 percent saturated to suction pressures of $15,000 \mathrm{~cm}$, the wilting point of typical grasses (Kohnke, 1968). Although the till lacks positive pressure heads in the test holes $\mathrm{L}$ and $\mathrm{Q}$, it is likely that it remains nearly saturated. Thus, the lack of a detectable difference in moisture content between test holes $\mathrm{L}$ and $\mathrm{Q}$ and test hole U can be explained by the till's ability to remain saturated or nearly so even without positive pressure heads.

All piezometers screened in the till that had positive pressure heads near the burial site showed yearly fluctuations in water levels. The deep piezometers consistently showed smaller and less erratic fluctuations and later seasonal peaks than the shallow piezometers. Peak water levels in the deepest piezometers lagged almost 6 months behind those in the shallowest piezometers. Water levels in several piezometers are shown in figure 14. These water-level fluctuations seem to reflect seasonal variation in infiltration and transpiration near land surface.

Several piezometers next to trenches 5 and 2 responded to the pumpout of water from those trenches in 1976 and 1977 (figs. 14B, 14C, and 7), but those further away did not (figs. $14 A$ and 7 ). The decline of water levels in piezometers near trench 5 was most rapid in those finished near the reported altitude of the trench floor (D-1, E-2, and F-2) or in sandy backfill next to trench 5 (E-1) (Prudic, 1981). Piezometers next to trench 2 showed a smaller response than those next to trench 5 (figs. 14B, $14 C)$ because the water-level change in trench 2 caused by pumping was smaller (Prudic, 1981). Piezometers near the south trenches showed no response to the pumpout of water from trenches 10,11 , and 14 in November 1977 (fig. 14D); however, the change in water levels in these trenches was also smaller than in trench 5 .

The sudden water-level increases in piezometers D-2 and F-3 (fig. 14B) in May and June 1976 were caused by attempts to sample the piezometers (Prudic, 1981). Nitrogen was injected at pressures as high as $4.2 \mathrm{~kg} / \mathrm{cm}^{2}$ down the larger of two tubes that extended to the piezometer screen and forced water up the smaller tube to the surface. Apparently, this deformed the till and spread it away from the column of hardened cement grout above the piezometer. Because total head in the till declines with depth, the water level rose when water from shallower depth entered the piezometer. The subsequent decline in water level reflects partial resealing of till against the grout column as well as a response to trench pumpout. Although the two effects cannot be separately measured, the water-level trends in piezometer D-2 and F-3 caused by the pumpouts were, for purposes of model calibration, estimated from measurements in E-3, which was finished at similar depth along the west side of trench 5 (Prudic, 1981).

\section{FLOW WITHIN THE UNDERLYING LACUSTRINE UNIT}

The lacustrine sequence (units 6-9 in table 4) of layered silts and clays that grade upward into unsaturated fine sand was encountered beneath the till near the burial site. The top of the lacustrine sequence near the trenches is at an altitude of about $391 \mathrm{~m}$, or about $23 \mathrm{~m}$ below the trench floor. Three piezometers finished within the saturated part of the lacustrine sequence fluctuated less than $20 \mathrm{~cm} / \mathrm{yr}$. The direction of lateral flow through the sequence, as determined from heads in the three piezometers, is to the northeast toward Buttermilk Creek (fig. 15). A downward gradient through this sequence and into the underlying drift is also possible, but the rate of downward flow through the layered lacustrine sequence would probably be much slower than the rate of lateral flow. Neutron-porosity logs of test holes $\mathrm{J}, \mathrm{V}$, and $\mathrm{W}$ show a sharp break in the profile at or near the contact between the till and the lacustrine sequence. The sharp break coincides with the unsaturated part of the sequence. The profile does not 
show another sharp break until the water level in the piezometers is encountered. If the sharp breaks in the neutron-porosity logs had occurred above the water level in the piezometers, a downward head in the lacustrine sequence could be postulated. However, because the logs did not break until the water level in the piezometers was encountered, the vertical gradient within the lacustrine sequence is probably small. Therefore, the flow direction indicated in figure 15 and the lateral gradient of ground water in the lacustrine sequence near the burial site are probably correct.

\section{COMPUTER SIMULATION OF GROUND-WATER FLOW}

Ground-water flow at the burial site near West Valley was analyzed by a computer model. A computer program written by Reeves and Duguid (1975) was used to quantify factors that control ground-water flow near the burial trenches because the program allows for a moving water table and unsaturated conditions in two dimensions along a vertical section. A two-dimensional model was used because the flow directions in the till are generally vertical, as evidenced by hydraulic heads in piezometers.

The modeling effort was directed toward simulating ground-water flow in a vertical section (1) across the north trenches from test hole $G$ eastward to Franks Creek, (2) across the south trenches from test hole $\mathrm{K}$ through test hole $\mathrm{N}$ to Franks Creek, and (3) from trench 4 northward through test holes $\mathrm{C}$ and $\mathrm{Z}$ to a tributary of Franks Creek (sections are shown in fig. 7). Modeling was especially useful in evaluating anisotropy in the till and variations in hydraulic conductivity with depth. The development and calibration of the model are described in detail by Prudic (1981); much of the following material is adapted from that report.

Reeves and Duguid (1975, p. 10) state that the equations representing flow in saturated and unsaturated porous media consist of equations for

1. continuity of the water;

2. continuity of the matrix;

3. motion of the water;

4. consolidation of the matrix; and

5. compressibility of the water.

They combined these equations into one:

$$
\begin{aligned}
\left(\frac{\theta}{n} \alpha^{\prime}+\theta \beta^{\prime}+\frac{d \theta}{d h}\right) \frac{\partial h}{\partial t} & =\frac{\partial}{\partial x}\left[\vec{K}\left(\frac{\partial h}{\partial x}\right)\right] \\
& +\frac{\partial}{\partial z}\left[\vec{K}\left(\frac{\partial h}{\partial z}+1\right)\right]
\end{aligned}
$$

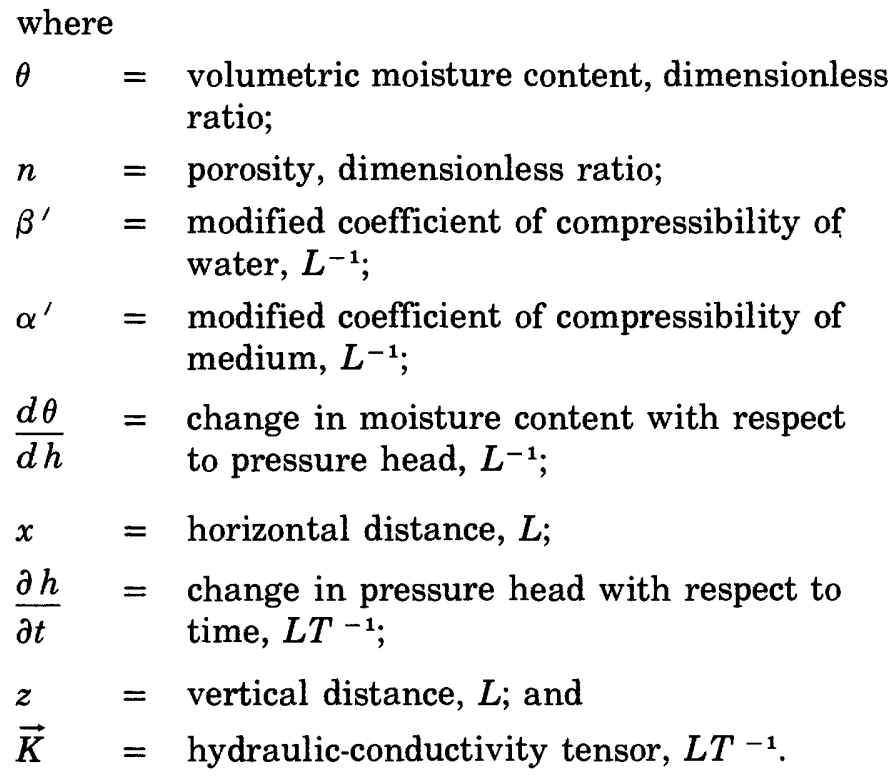

The hydraulic-conductivity tensor is dependent on pressure head, as shown in the following equation:

$$
\vec{K}=\vec{K}_{s}+K_{r}(h)
$$

where

$K \quad=$ hydraulic-conductivity tensor, $L T^{-1}$;

$K_{s}=$ saturated hydraulic-conductivity tensor, $L T^{-1}$;

$K_{r}(h)=$ relative hydraulic conductivity as a function of pressure head, dimensionless.

The computer program by Reeves and Duguid (1975) solves the two-dimensional saturated-unsaturated flow equation (eq. 2) by the Galerkin finite-element numerical technique in which the region of interest is divided into subregions or elements that may have irregular shapes. This results in a set of nonlinear algebraic equations that must first be linearized and then solved simultaneously. In solving the flow equation for irregular elements, the surface integrals are converted to volume integrals by the Gauss divergence theorem. The resultant equations are evaluated at a finite number of points, or nodes, that coincide with the vertices of and points interior to the elements. The type of finite-element method used by Reeves and Duguid is the Galerkin method which is explained by Pinder and Frind (1972); Neuman (1975); Finlayson and others (1978), and Lappala (1981).

In the Reeves and Duguid program, the time derivative $(\delta h / \delta t)$ is approximated by either the backwards difference or the centered-in-time difference 

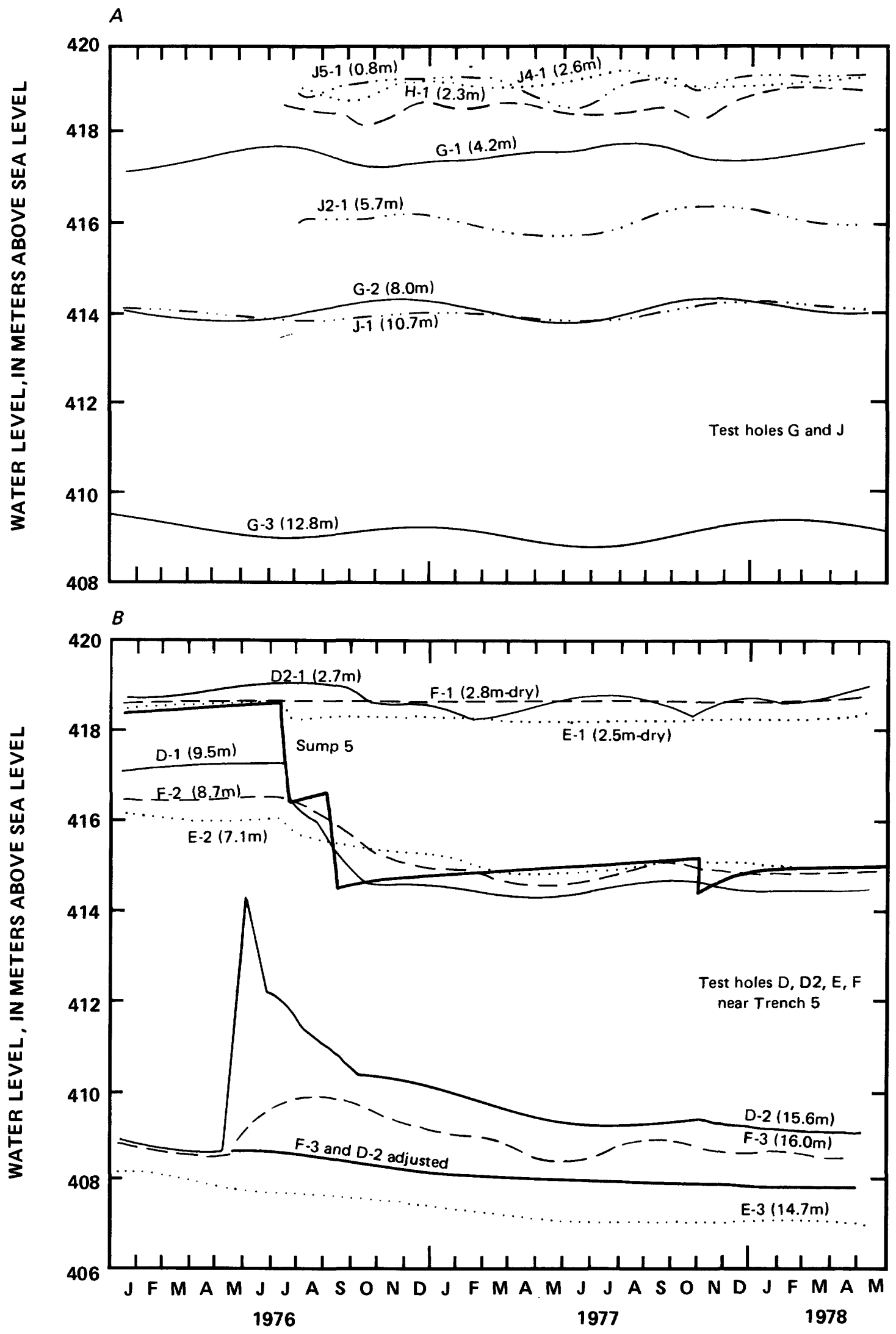

FIGURE 14.-Water-level trend in piezometers, January 1976 through May 1978. $A$, test holes G and J. $B$, Near trench 5 (test holes D, D2, E, and F). Test holes with more than one piezometer are numbered consecutively from the shallowest piezometer to the deepest piezometer. Numbers in parentheses indicate depth below land surface, in meters. Locations are shown in figure 7 (modified from Prudic, 1981). 
C
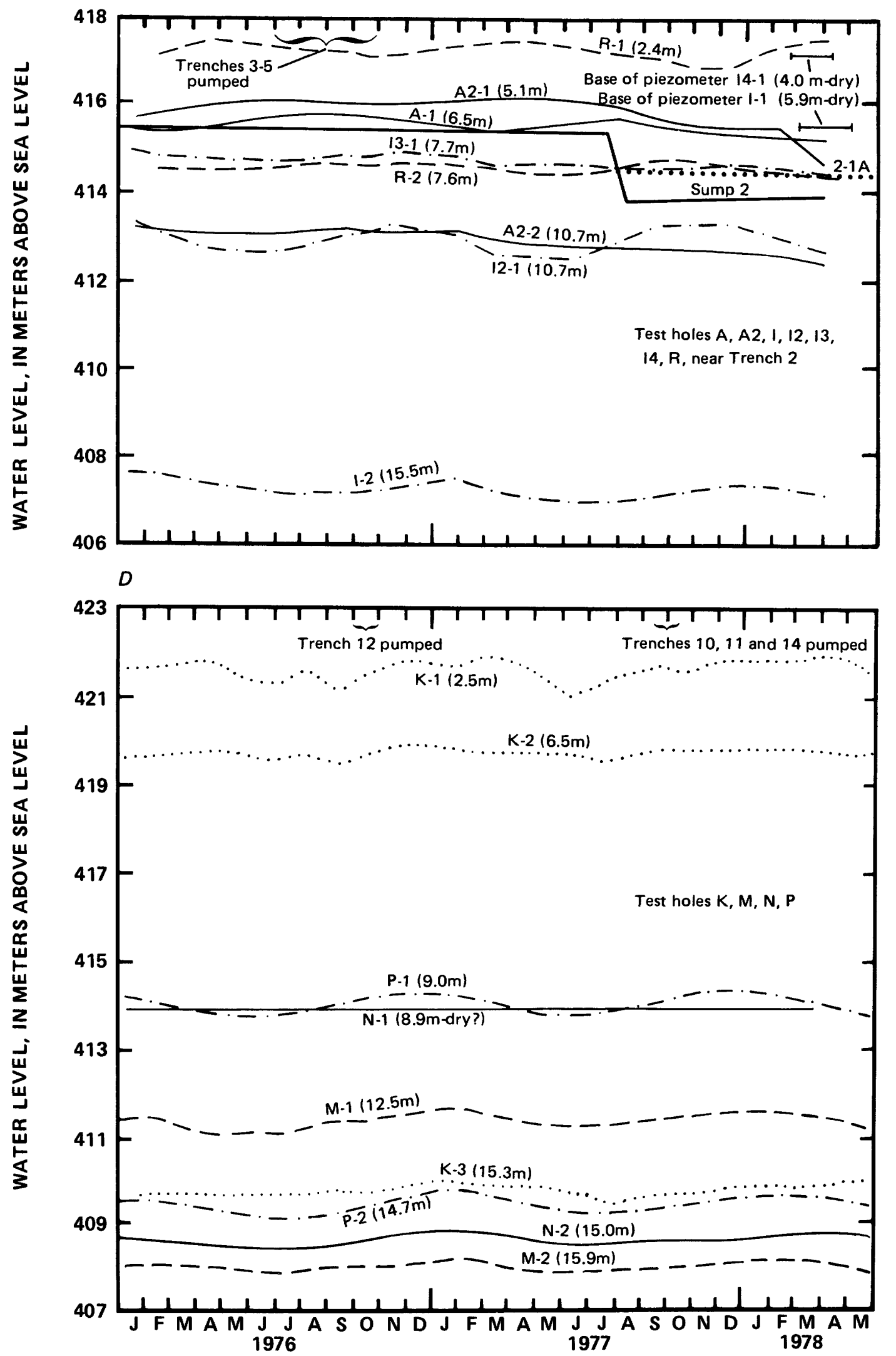

FIGURE 14.-Continued. Water level trend in piezometers, January 1976 through May 1978. C, Near trench 2 (test holes A, A2, I, I2, I3, I4, and R). D, Test holes K, M, N, and P. Test holes having more than one piezometer are numbered consecutively from the shallowest piezometer to the deepest piezometer. Numbers in parentheses indicate depth below land surface, in meters. Locations are shown in figure 7 (modified from Prudic, 1981.) 
(Crank-Nicholson) technique (Reeves and Duguid, 1975; for an explanation on the techniques, see Remson and others, 1971). The Crank-Nicholson technique for nonlinear problems leads to oscillatory instabilities, whereas the backwards difference technique does not. The backwards difference technique, however, has a lower order truncation error. The backwards difference technique was used in the simulation of ground-water flow through the till and can be approximated by:

$$
h_{1}-h_{0} / \Delta t
$$

where

$h_{0}=$ the pressure head in a node at the beginning of a time step (known), $L$;

$h_{1}=$ the pressure head in a node at the end of a time step (unknown), $L$; and

$\Delta t \quad=$ the time step interval, $T$.

The computer program is sensitive to the nonlinearity of the moisture content and hydraulic conductivity in the unsaturated zone. The program may fail to converge to an acceptable solution if the moisture content

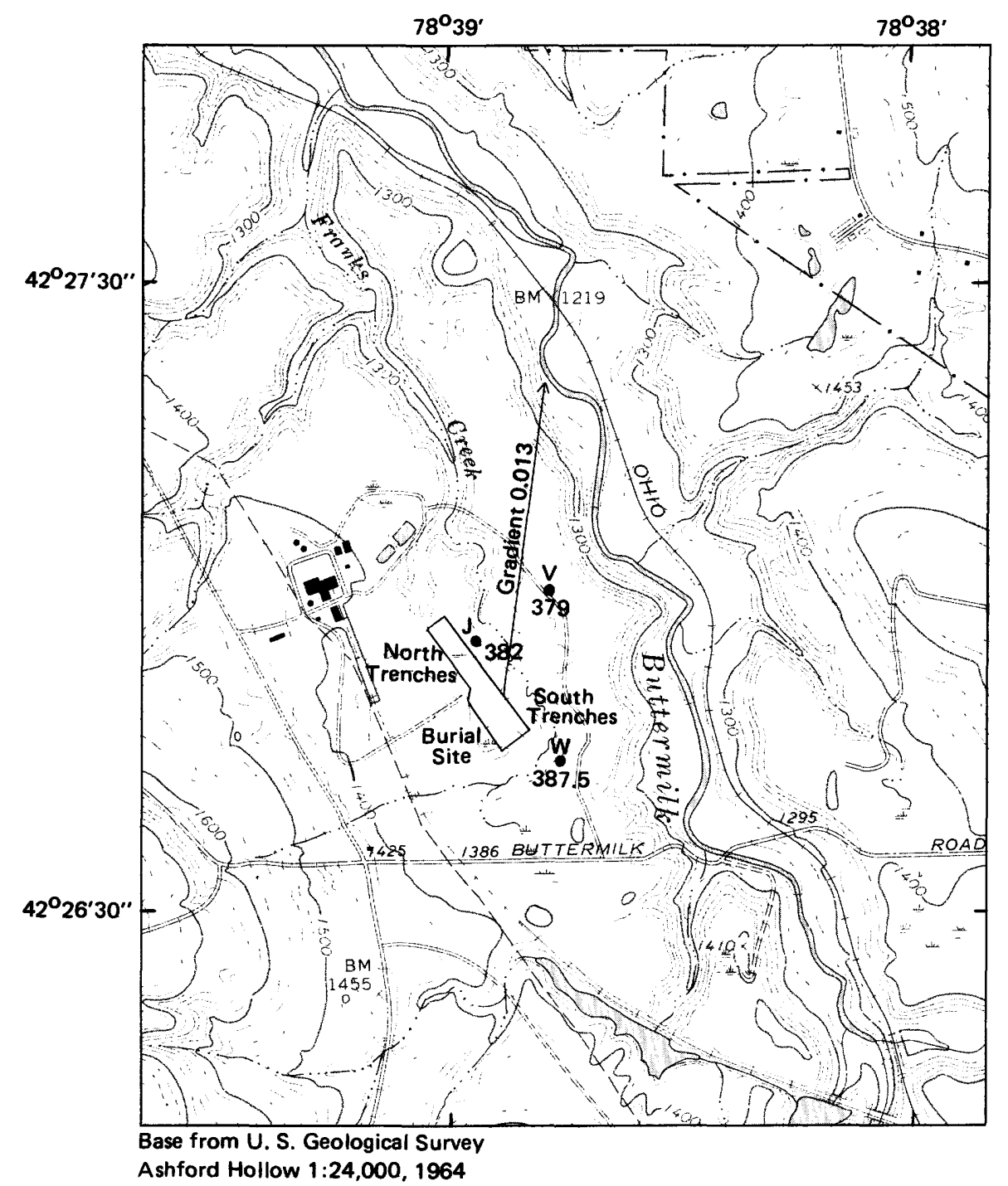

Ashford Hollow 1:24,000, 1964
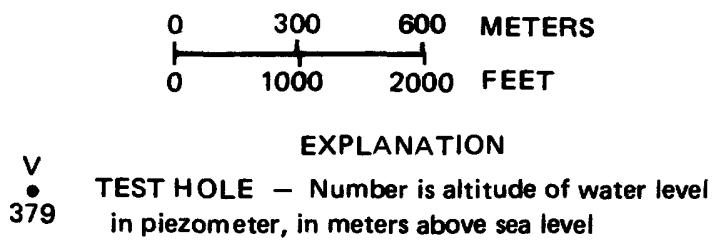

FIGURE 15.-Direction of ground-water flow in lacustrine sequence beneath the till, as determined from water levels in three piezometers. 
and hydraulic conductivity versus negative pressure heads (soil suction or tension) is very nonlinear-that is, if large changes in moisture content or hydraulic conductivity occur over short negative pressure-head intervals or between nodes that are spaced too far apart. However, because the till is nearly saturated and remains so over a large interval of negative pressure heads (fig. 11), the problem of nonconvergence did not occur in the simulations of ground-water flow through the till.

The boundary and internal conditions used in all modeled sections are as follows:

1. No-flow boundary on either side of the section because the hydraulic gradient is vertical.

2. In general, zero head at the base of the till to represent unsaturated conditions in the underlying silt. (A few model runs were made assuming the underlying silt to be saturated near hole G.)

3. Infiltration rate sufficient to saturate the till to land surface near swampy areas but less over smooth or steeply sloping areas to create local unsaturated conditions. This rate is the amount that will recharge the till. When pressure head in the surface node reaches a designated value (usually zero), the node switches from a flux boundary to a constant-head boundary.

4. A horizontal hydraulic conductivity of either $2 \times 10^{-8} \mathrm{~cm} / \mathrm{s}$ or $6 \times 10^{-8} \mathrm{~cm} / \mathrm{s}$ for the unweathered till, which is the estimate of the equivalent hydraulic conductivity of the till and the sorted material within the till as determined from field and laboratory tests.

5. Constant heads within the trenches equal to observed heads in February 1976 or February 1978 or, for a few transient-state simulations, an instantaneous change from one set of heads to another.

\section{NORTH TRENCHES}

The flow pattern along the vertical section $C-\mathrm{C}^{\prime}$ through the north trenches from test hole $\mathrm{G}$ eastward to Franks Creek (location of section is shown in fig. 7) was chosen for thorough exploratory simulations and model calibration because the distribution of heads in the till near these trenches had been observed both before and after the trench-water levels were lowered $4 \mathrm{~m}$ by pumping in 1976, a greater stress than observed elsewhere.

Several steady-state simulations were made with the boundary and internal conditions listed in the previous section to evaluate (1) the relative significance of anisotropy and (2) variations in hydraulic conductivity caused by fracturing and increased confining pressures in the till. Simulations started with a single isotropic unit and eventually included up to 5 model units (in- cluding lenses of silt and sand as a unit). As a general index of closeness of fit, the mean absolute departure (positive or negative) of simulated heads from observed heads at piezometers in the plane of section was calculated for each simulation. Results of the various simulations are presented in Prudic (1981, table 1) and are summarized in the following paragraphs.

Simulations that incorporated a single isotropic unit produced the same pressure heads regardless of hydraulic conductivity and had a mean absolute departure of $201 \mathrm{~cm}$. All simulated pressure heads were less than observed heads. As expected, changes in computed inflow and outflow rates were directly proportional to any change in hydraulic conductivity. Anisotropy (horizontal hydraulic conductivity greater than vertical) lowered the mean absolute departure in the simulations to $114 \mathrm{~cm}$ when the horizontal hydraulic conductivity was 100 times greater than the vertical. Simulating a shallow unit to represent the abundantly fractured, weathered till with a higher hydraulic conductivity than the unweathered till also lowered the mean absolute departure $(123 \mathrm{~cm}$ when the weathered till was 10 times more permeable than the unweathered till). Increasing the hydraulic conductivity of the weathered till produced slightly greater mean absolute departures. Simulating anisotropy in the two units further reduced the mean absolute departures. However, the lowest mean absolute departures occurred when four isotropic layers were simulated, each with a different hydraulic conductivity, to represent fracturing near land surface and increased consolidation of the till with depth. The mean absolute departure was $21 \mathrm{~cm}$ for the February 1976 simulation and $29 \mathrm{~cm}$ for the February 1978 simulation.

In the best simulation, hydraulic conductivity of the uppermost layer, which represented the distance from land surface to the base of oxidation in the till, was calibrated to be about 10 times higher than that of the deeper unweathered till below (layer 3). Hydraulic conductivity of the second layer, which represented the zone in the unweathered till containing oxidized fractures, was calibrated to be about 5 times higher than that of the deeper unweathered till (layer 3). Hydraulic conductivity of the fourth layer, a layer about $10 \mathrm{~m}$ thick at the base of the unweathered till, was calibrated to be 15 to 30 percent less than that of the bulk of the unweathered till to simulate the reduction in hydraulic conductivity with depth. To duplicate heads in three piezometers finished in silt and sand lenses in test holes $\mathrm{D}, \mathrm{J}$, and I, it was necessary to simulate the individual lenses and adjust their extent as well as their hydraulic conductivity during calibration.

The best simulations with anisotropy included three units-the weathered zone, the unweathered till with fractures, and the unweathered till-and also the local- 
ized silt and sand lenses near piezometers in test holes $\mathrm{D}, \mathrm{J}$, and I. In these simulations, the weathered till unit had a horizontal hydraulic conductivity 10 times greater than the unweathered till, and the unweathered till with oxidized fractures and the localized silt and sand lenses had a value 5 times greater than the unweathered till. The horizontal hydraulic conductivity was 10 times higher than the vertical in all three layers; localized silt and sand lenses were assumed to be isotropic. The mean absolute departure was $46 \mathrm{~cm}$ for the February 1976 simulation and $64 \mathrm{~cm}$ for the February 1978 simulation $(53 \mathrm{~cm}$ and $62 \mathrm{~cm}$, if piezometers I-1 and I4-1 are included). Table 10 compares simulated pressure heads from the best computer simulations with observed values from both the anisotropic and isotropic conditions for February 1976 and February 1978.
The isotropic simulations produced smaller average departures than the anisotropic simulations and also were qualitatively more reasonable in at least two respects: (1) they simulated negative heads at piezometers I-1 and I4-1, which were dry on both dates, whereas the best anisotropic simulations produced positive heads, and (2) they simulated about the same heads for both dates in piezometers at test hole $\mathrm{G}$, in agreement with observed conditions, whereas the best anisotropic simulations produced significantly lower heads for test hole $\mathrm{G}$ in February 1978 in response to the lower water level simulated in the trenches.

The final or best-fit distribution of hydraulic conductivity with depth between test hole $\mathrm{G}$ and Franks Creek, which incorporates four isotropic layers of differing hydraulic conductivity to reflect fracturing near the sur-

TABLE 10.-Heads observed in February 1976 and February 1978 compared with results of best-fitting computer simulations for isotropic and anisotropic conditions 1

[All values are in centimeters. Location of test holes are shown in figure 7]

\begin{tabular}{|c|c|c|c|c|}
\hline $\begin{array}{c}\text { Test hole } \\
\text { identiflcation } \\
\text { followed by } \\
\text { piezometer number }\end{array}$ & $\begin{array}{c}\text { Calculated } \\
\text { heads from best } \\
\text { computer simulation } \\
\text { with anisotropy }\end{array}$ & $\begin{array}{c}\text { Absolute } \\
\text { departure from } \\
\text { observed heads }\end{array}$ & $\begin{array}{c}\text { Calculated } \\
\text { heads from best } \\
\text { computer simulation } \\
\text { with isotropic conditions }\end{array}$ & $\begin{array}{c}\text { Absolute } \\
\text { departure from } \\
\text { observed heads }\end{array}$ \\
\hline \multicolumn{5}{|c|}{\begin{tabular}{|l} 
February 1976 \\
\end{tabular}} \\
\hline 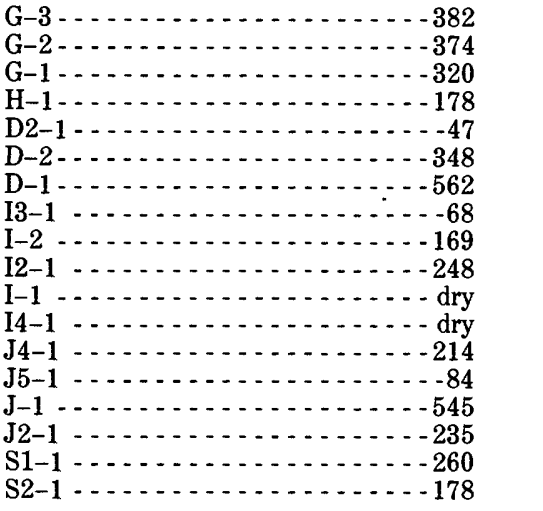 & $\begin{array}{r}254 \\
276 \\
291 \\
187 \\
46 \\
308 \\
629 \\
142 \\
218 \\
220 \\
91 \\
144 \\
202 \\
45 \\
537 \\
166 \\
221 \\
140\end{array}$ & $\begin{array}{r}128 \\
98 \\
29 \\
9 \\
1 \\
40 \\
67 \\
74 \\
49 \\
28 \\
>91 \\
>144 \\
12 \\
39 \\
8 \\
69 \\
39 \\
38\end{array}$ & $\begin{array}{r}359 \\
330 \\
307 \\
187 \\
47 \\
359 \\
560 \\
89 \\
173 \\
180 \\
-79 \\
-96 \\
219 \\
46 \\
524 \\
288 \\
262 \\
152\end{array}$ & $\begin{array}{r}23 \\
44 \\
13 \\
9 \\
0 \\
11 \\
2 \\
21 \\
4 \\
48 \\
? \\
? \\
? \\
5 \\
38 \\
21 \\
53 \\
2 \\
26\end{array}$ \\
\hline & $\begin{array}{r}\text { Mean absolut } \\
\text { Standa }\end{array}$ & $\begin{array}{l}\operatorname{are}^{2} \\
\text { tion } \\
\end{array}$ & & $\begin{array}{l}21 \\
20 \\
\end{array}$ \\
\hline \multicolumn{5}{|c|}{ February 1978} \\
\hline 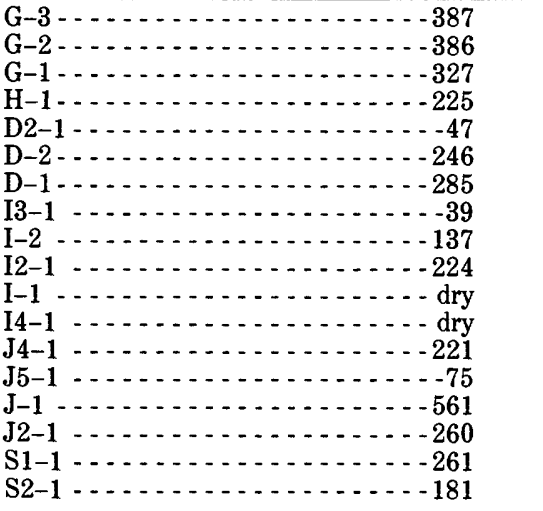 & $\begin{array}{r}179 \\
221 \\
277 \\
177 \\
26 \\
172 \\
322 \\
94 \\
155 \\
152 \\
67 \\
32 \\
200 \\
45 \\
526 \\
158 \\
221 \\
138\end{array}$ & $\begin{array}{r}208 \\
165 \\
50 \\
48 \\
21 \\
74 \\
37 \\
55 \\
18 \\
72 \\
>67 \\
>32 \\
21 \\
30 \\
35 \\
102 \\
40 \\
43\end{array}$ & $\begin{array}{r}360 \\
329 \\
304 \\
188 \\
15 \\
220 \\
268 \\
73 \\
152 \\
158 \\
-22 \\
-154 \\
220 \\
48 \\
520 \\
286 \\
262 \\
152\end{array}$ & $\begin{array}{r}27 \\
57 \\
23 \\
37 \\
32 \\
26 \\
17 \\
34 \\
15 \\
66 \\
? \\
? \\
1 \\
27 \\
41 \\
26 \\
1 \\
29\end{array}$ \\
\hline S2-1 $\ldots \ldots \ldots \ldots \ldots \ldots$ & $\begin{array}{r}\text { Mean absolute } \\
\text { Standa }\end{array}$ & $\begin{array}{l}64 \\
53\end{array}$ & & $\begin{array}{l}29 \\
17\end{array}$ \\
\hline
\end{tabular}

1 From Prudic, 1981

2 Piezometers I-1 and I4-1 were not included in the calculation of the mean absolute departure. 
face and consolidation of the till with depth, is shown in figure 16 along with boundary conditions used to simulate heads of February 1976 and February 1978. The observed heads in the trenches and in the till on both dates are assumed to represent constant (steadystate) conditions. Simulated heads within the till for these two dates are shown in figure 17 (observed heads are plotted next to piezometer symbols); the only difference is the lower heads immediately next to the trenches in 1978, which is consistent with field observations.

Initially the infiltration rates were set high enough to saturate the till to land surface everywhere; later they were reduced enough to cause the uppermost nodes to become unsaturated at most locations. In anisotropic simulations, this reduction resulted in a slight lowering of heads in most nodes throughout the modeled section. In isotropic simulations, this reduction resulted in a large lowering of heads in all nodes beneath locations where infiltration from land surface was the only source of water but not near the constant-head nodes that represented the water levels in the trenches. Thus, a large decline in head resulted at all depths near test holes $\mathrm{H}$ and $\mathrm{J}$, but little change occurred below the depth of the trench bottoms near test holes D and I.
Infiltration rates near shallow depressions were adjusted to just saturate the till to land surface. The calibrated infiltration rate near the shallow depressions was set at about $3 \mathrm{~cm} / \mathrm{yr}$ when the horizontal hydraulic conductivity of the unweathered till was $6 \times 10^{-8} \mathrm{~cm} / \mathrm{s}$ and the distribution of hydraulic conductivity in the vertical section was the same as shown in figure 16. Lowering all hydraulic conductivities by a factor of 3 to simulate the lower estimate in hydraulic conductivity of the unweathered till required that the simulated infiltration rate near the shallow depressions be lowered to about $1 \mathrm{~cm} / \mathrm{yr}$-also a factor of 3 . The calibrated infiltration rate on smooth, sloping surfaces such as near test holes $\mathrm{D}$ and I was set less than the rate near depressions to simulate a shallow unsaturated zone, as explained in the previous paragraph; a range of 1.1 to 0.4 $\mathrm{cm} / \mathrm{yr}$ was found to correspond to the estimate in hydraulic conductivity of the unweathered till $-6 \times 10^{-8} \mathrm{~cm} / \mathrm{s}$ to $2 \times 10^{-8} \mathrm{~cm} / \mathrm{s}$.

Transient conditions from June 1976 through May 1977 were simulated in an attempt to reproduce observed drawdowns in piezometers near trench 5 after water was pumped from trenches 3 through 5 in the summer of 1976 and to calibrate the saturated specific storage of the unweathered till. Specific storage, which

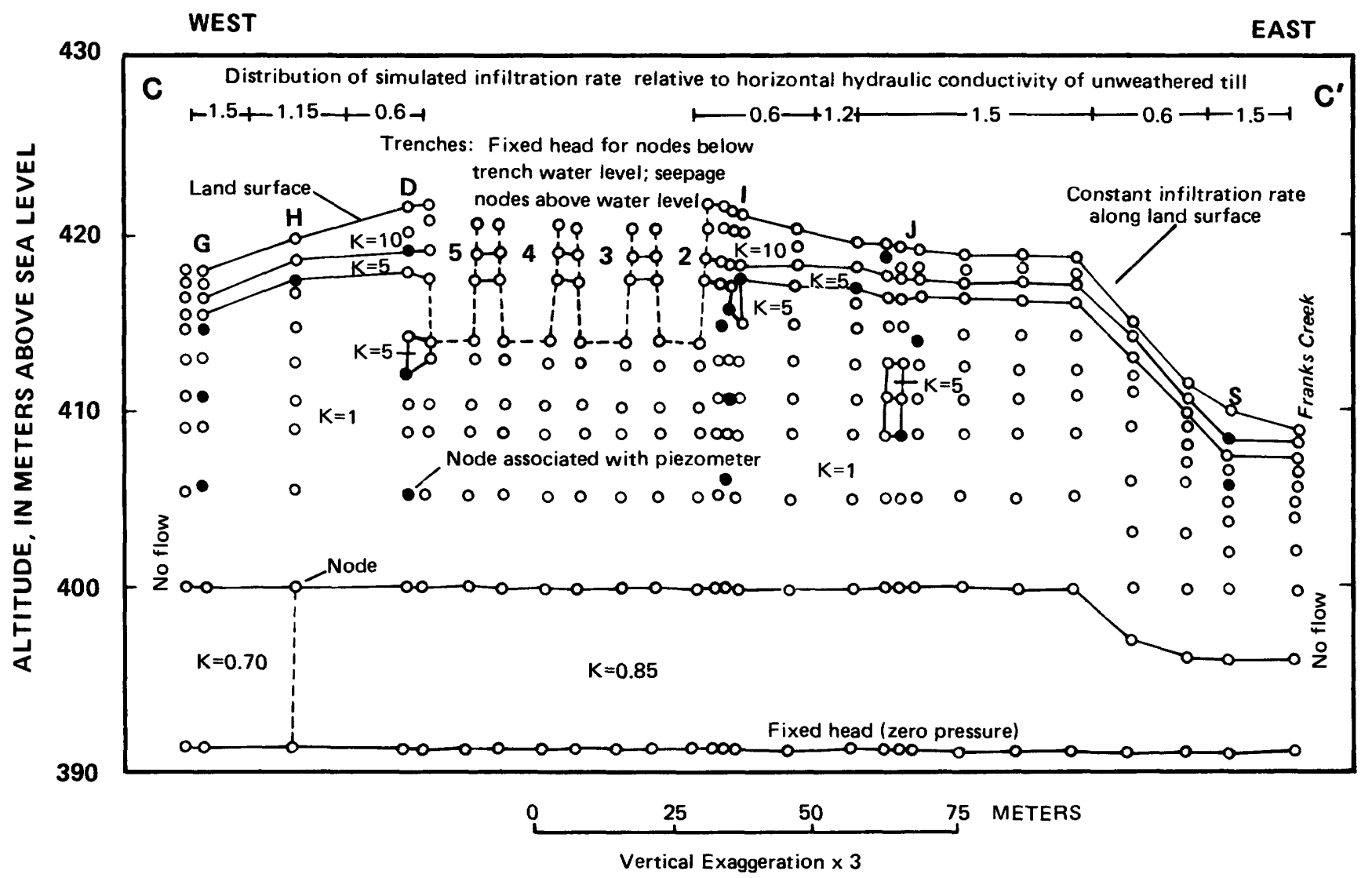

FIGURE 16.-Vertical section C-C' through north trenches showing node arrangement, boundary conditions, relative hydraulic conductivity values, and relative infiltration rates used in best-fit simulation. Location of section is shown in figure 7 (from Prudic, 1981). 
A
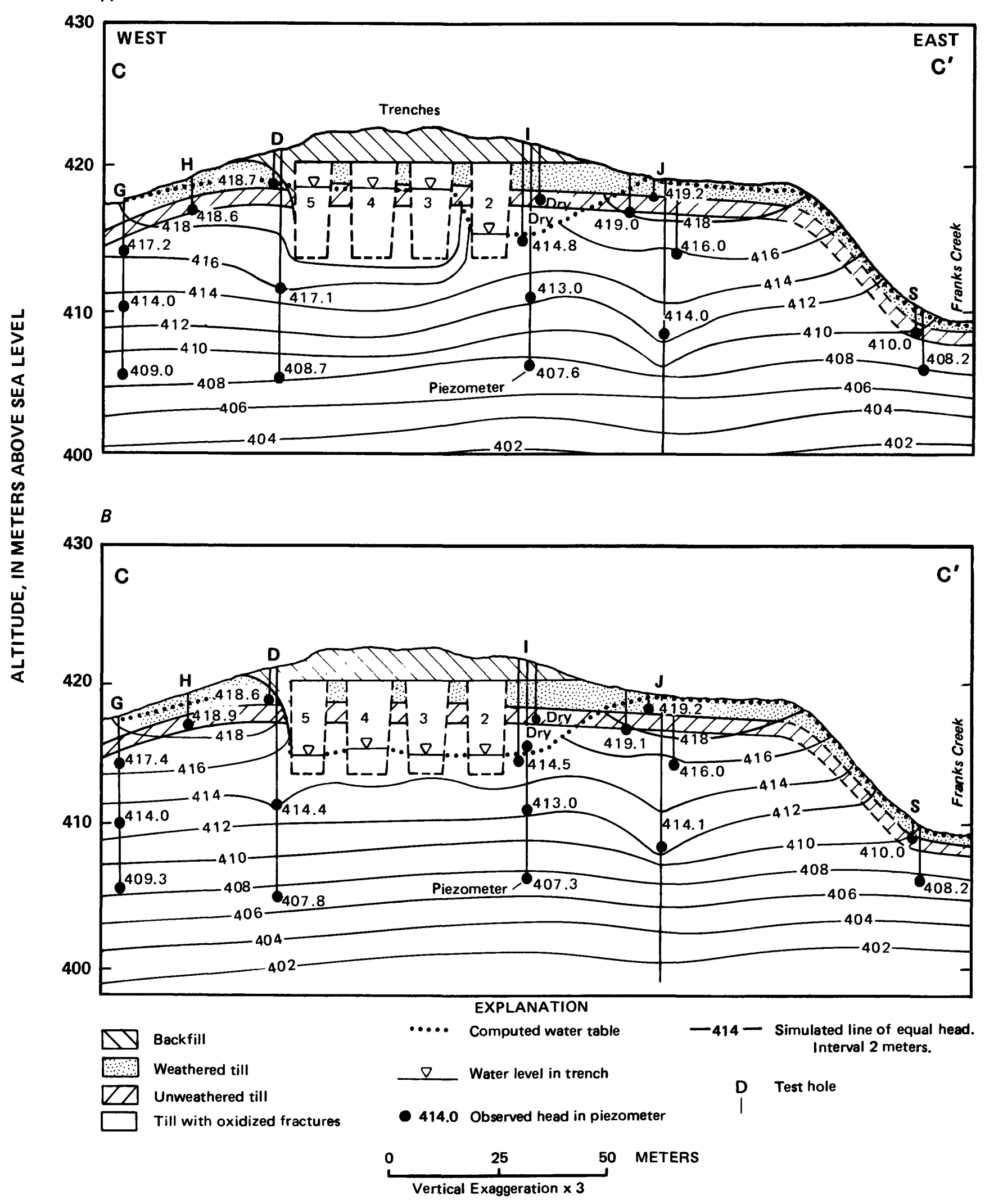

FIGURE 17.-Vertical section C-C ${ }^{\prime}$ through north trenches showing computer-simulated distribution of heads. A, February 1976. B, February 1978. Location of section is shown in figure 7 (from Prudic, 1981). 
was defined in the section "Physical and hydraulic properties of the till," is indirectly a required input to the model. That is, it is exactly equal to the sum of the modified compressibility of the till and water (terms in equation 2) and is essentially equal to the modified compressibility of the till because the modified compressibility of water at $10^{\circ} \mathrm{C}$ is 100 times less (Prudic, 1981, p. 229). Transient simulations that assumed a hydraulic conductivity of $6 \times 10^{-8} \mathrm{~cm} / \mathrm{s}$ for the unweathered till and used the distribution of hydraulic conductivity and infiltration rates of the best steady-state simulation reproduced the observed hydraulic heads in piezometers in test hole $\mathrm{D}$ when the specific storage value of the till was $9 \times 10^{-6}$ per $\mathrm{cm}$ (fig. 18). This value is close to the average specific storage of $8 \times 10^{-6}$ per $\mathrm{cm}$ as determined from four laboratory consolidation tests, which as noted earlier ranged from $16 \times 10^{-6}$ per $\mathrm{cm}$ at a depth of $5.8 \mathrm{~m}$ to $2 \times 10^{-6}$ per $\mathrm{cm}$ at a depth of $16 \mathrm{~m}$. Additional transient simulations were run for the same period in which all hydraulic-conductivity values and infiltration rates were proportionately reduced by a factor of 3 to incorporate the uncertainty of the estimate in hydraulic conductivity of the unweathered till as determined from field and laboratory tests. These simulations reproduced the observed hydraulic head distribution when the specific storage was reduced to $3 \times 10^{-6}$ per $\mathrm{cm}$ again by a factor of 3 . The transient simulations also indicated that only next to the trenches did water levels in the till decline appreciably in response to the pumpout of trench water (again in agreement with the observed response to the pumpout).

\section{SOUTH TRENCHES}

Head distribution along a section perpendicular to the south burial trenches (8-14) from test hole $\mathrm{K}$ through

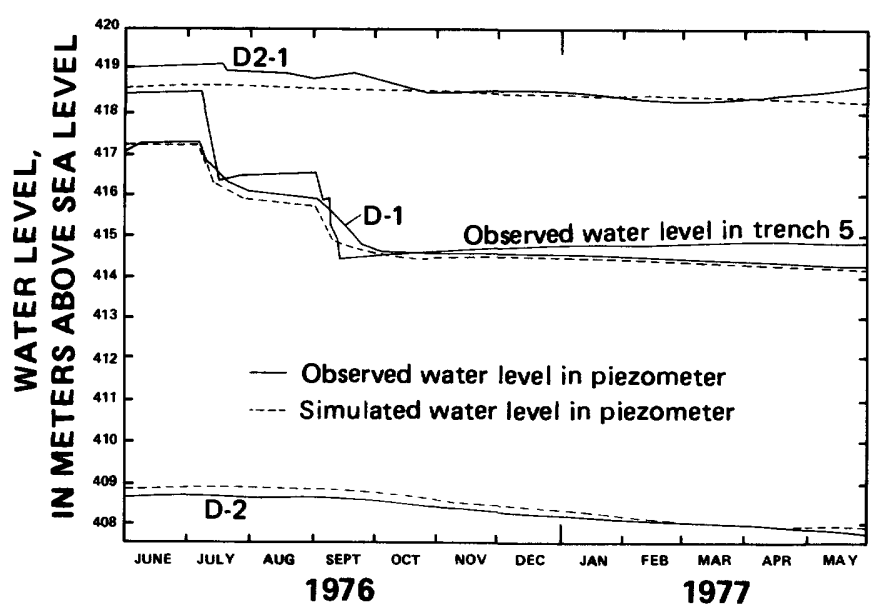

FIGURE 18.-Comparison of computer-simulated water levels with observed water levels in piezometers D-1, D-2, and D2-1 during 8 months after pumpout of water from trench 5 . Location of test holes is shown in figure 7 (from Prudic, 1981). test hole $\mathrm{N}$ to Franks Creek (figs. 7 and $13 B$ ) was simulated as shown in figure 19 by assuming boundary conditions and hydraulic-conductivity values to be similar to those used in the best-fit computer model of section $\mathbf{C}-\mathrm{C}^{\prime}$ through the north burial trenches. To improve calibration, infiltration rates were modified slightly from those used in model calibration of the north burial area (Prudic, 1981) but were similar in principlehighest in flat, shallow depressions such as near test hole $\mathrm{K}$, lowest (50 to 60 percent less) on smooth, sloping surfaces (near $\mathrm{N}$ and $\mathrm{L}$ ), and intermediate elsewhere (fig. 19). The model adequately simulated heads of February 1978; absolute departure from observed heads at the seven piezometers in the plane of section that had positive heads was $20 \mathrm{~cm}$, and unsaturated conditions were indicated near test holes $\mathrm{L}$ and $\mathrm{N}$ (fig. 19).

\section{LIMITATIONS AND RESULTS}

In the process of model calibration, the twodimensional array of pressure heads provided a considerable constraint that helped to confirm isotropy and establish the thickness and relative hydraulic conductivity of various layers and lenses. Nevertheless, model calibration depends on four interpretations, as summarized below:

1. The till within each model layer has uniform hydraulic conductivity (except for individually modeled lenses), but infiltration rates vary laterally along the lines of section. An acceptable calibration might also have been achieved by assuming infiltration to be areally uniform and hydraulic conductivity to vary laterally along the section, but this alternative does not seem plausible for three reasons. First, smooth, graded slopes were observed to produce rapid runoff and to dry quickly after rainstorms, whereas in level areas, the natural soil provided prolonged storage. This variation would negate areally uniform infiltration rates. Second, no systematic areal differences in lithology, frequency of lenses, or hydraulic conductivity between areas of low and high pressure heads were recognized from cores or from slug tests of piezometers. Third, the mode of origin of the till suggests that lithologic variations are localized and do not occur over the entire thickness.

2. The hydraulic conductivity of the unweathered till is between $2 \times 10^{-8} \mathrm{~cm} / \mathrm{s}$ and $6 \times 10^{-8} \mathrm{~cm} / \mathrm{s}$. If hydraulic conductivity, infiltration rate (an unknown), and specific storage were all increased or decreased in the same proportion, the same head distribution would be generated by the model, and estimates of ground-water flow based on the model 

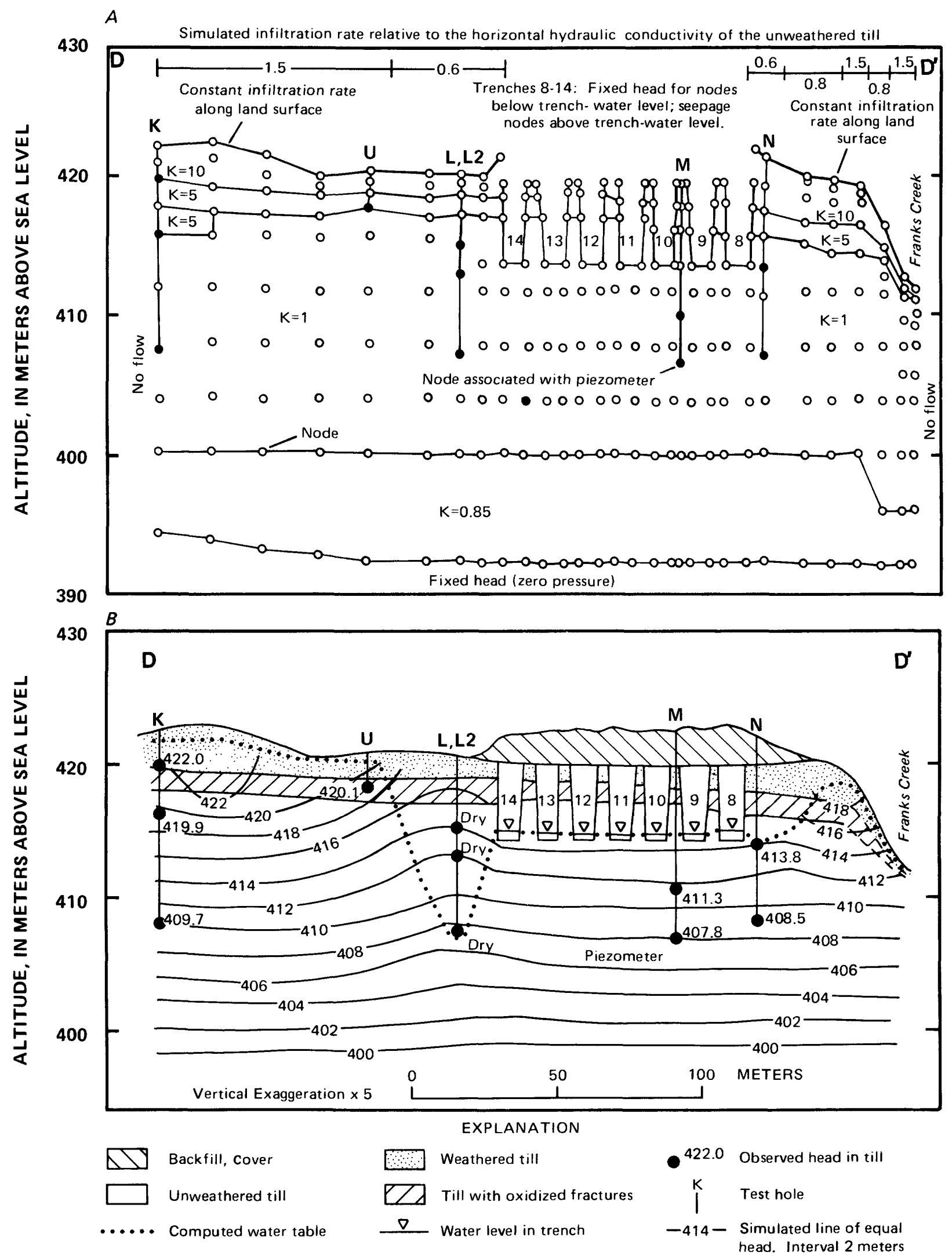

FIGURE 19.-Vertical section D-D' through south trenches. A, Node arrangement, boundary conditions, relative hydraulicconductivity values, and relative infiltration rates used in best-fit simulation. $B$, Computer-simulated distribution of heads for till for February 1978. Location is shown in figure 7. 
would also change proportionately. However, considerable laboratory and field evidence (presented earlier) points to the hydraulic conductivity values cited. Furthermore, the fact that transient-state simulations incorporating these values achieved best fit with a specific storage value within the range of the four available laboratory determinations of specific storage provides some support for the validity of the hydraulic-conductivity estimate.

3 . The till is nearly isotropic. This conclusion is important because model results are sensitive to anisotropy in the till. Field observations and field and laboratory tests of the till, presented earlier, support this conclusion. Futhermore, incorporating higher horizontal than vertical hydraulic conductivity in the till produced positive pressure heads in places east of trench 2 , east of trench 8 , and west of trench 14 where piezometers were dry or had very low pressure heads. Also, simulations of February 1978 conditions after water was pumped from the north trenches resulted in lower simulated heads than those observed in the field.

4. There is no flow perpendicular to the plane of the vertical sections modeled. Vertical sections $\mathrm{C}^{-\mathrm{C}^{\prime}}$ and D-D ${ }^{\prime}$ were selected to cross the trenches about midway along their lengths. Water levels in the trenches are generally uniform (Prudic, 1978); therefore, the horizontal hydraulic gradients in the till beneath the trenches and parallel to them should be nearly zero. In general, horizontal hydraulic gradients in the till adjacent to the trenches are much smaller than the vertical gradients, which generally approach 1 , and, because the till is nearly isotropic, the main flow direction of water is downward. For example, piezometers E-2 and F-2 on the west side of trench 5 and perpendicular to the vertical section $\mathbf{C}-\mathbf{C}^{\prime}$ are finished in the till within a meter of the same altitude. The horizontal gradient between these piezometers is at least $\mathbf{5 0 0}$ times less than the vertical gradient at test holes D, E, and F. The horizontal hydraulic gradient is even lower (greater difference between vertical and horizontal gradients) if the difference in altitude between the piezometers is included in the calculation. Similarly, the horizontal hydraulic gradient between piezometers $\mathrm{P}-2$ and N-2 perpendicular to the vertical section D-D' (fig. 7), which are also finished in the till within a meter of the same altitude, is at least 250 times less than the vertical gradient in test holes $M$ and $P$. Again, the horizontal hydraulic gradient would be less if the altitude difference between the two piezometers were included in the calculation. Flow across the vertical section $\mathrm{E}-\mathrm{E}^{\prime}$ (fig. 7) is also probably small because the section parallels the main direction of flow, and hydraulic heads are probably similar at the same altitudes along the slope to the nearby stream. Thus, the assumption of zero flow across the vertical sections modeled is valid.

Model simulations indicated ground-water discharge near Franks Creek and the small stream near test hole G. Average seepage in these areas was calculated to be between 25 and $75\left(\mathrm{~cm}^{3} / \mathrm{d}\right) / \mathrm{m}^{2}$ of surface area, depending on the hydraulic conductivity used in the simulations, but this rate occurred at only one node in the model. This seepage would be derived largely from flow through the weathered till from precipitation that infiltrated along the slopes. Near the area of discharge are marshy areas that could be the result of shallow ground-water seepage, but the seepage rates could not be verified in the field because the streams bordering the site are small and were often dry. Presumably, most of the water that discharges at land surface is consumed by evapotranspiration.

In general, water in the trench area moves vertically downward through the till. The average specific flux of water in the vicinity of trenches 3 through 5 in February 1976 was calculated to be between 0.5 and $2 \mathrm{~cm} / \mathrm{yr}$, and, for February 1978, between 0.3 and $1.5 \mathrm{~cm} / \mathrm{yr}$. These rates were calculated from an average uniform hydraulic conductivity of the unweathered till of $2 \times 10^{-8}$ to $6 \times 10^{-8} \mathrm{~cm} / \mathrm{s}$. The lower rates for February 1978 reflect lower water levels in trenches 3 through 5 . A rate of 0.3 to $1.5 \mathrm{~cm} / \mathrm{yr}$ in February 1978 in the vicinity of trenches 8 through 14 was calculated also.

The average linear (pore) velocity is equal to the specific flux divided by the effective porosity and is the rate of advective transport of radionuclides through the till. Assuming an effective porosity equal to the total porosity of 0.3 , the average linear velocity in the vicinity of trenches 3 through 5 in February 1976 would be between 1.7 and $6.7 \mathrm{~cm} / \mathrm{yr}$ and in February 1978 between 1 and $5 \mathrm{~cm} / \mathrm{yr}$. The average linear velocity in the vicinity of trenches 8 through 14 in February 1978 was also between 1 and $5 \mathrm{~cm} / \mathrm{yr}$. However, other processes affect the transport of radionuclides through the till, such as hydrodynamic dispersion, reactions with the till and the original pore water, and radioactive decay. The processes that cause or inhibit the migration of radionuclides at this burial site are discussed in the section "Migration rates."

\section{SEEPAGE FROM TRENCHES TO NEAREST STREAMS}

Simulated and observed heads in the till indicate that water flows vertically downward from the trench floors, 
through the till to the lacustrine sequence (units 8 and 9 , table 4) about $23 \mathrm{~m}$ below the trench floors, and then laterally northeastward through saturated coarse silt about $840 \mathrm{~m}$ (fig. 15) to the bluffs along Buttermilk Creek, where it will discharge. If some of the trench water could flow to one of the small streams that nearly surround the burial site, however, that flow path (and the time before radionuclides could reach land surface) would be much less. Although estimated flow paths from the trenches do not come close to these streams along the two sections calibrated (figs. 17 and 19) for 1976 and 1978 conditions, several model simulations were made to test flow to these streams under a steeper gradient.

The shortest distance and greatest vertical relief between a trench and an adjacent stream are at the north end of trenches 3 and 4 (fig. 7). To evaluate this as a possible flow path, shallow piezometers were installed' along the slope from trench 4 to the small stream north of trench 4, in line with test holes C, C2 (less than $3 \mathrm{~m}$ north of $\mathrm{C}$ ), and an older test hole (2C) installed for an earlier project (fig. 7). Simulations along this vertical section, which assumed the same boundary conditions as the other sections (fig. 20) except for minor adjustments of the infiltration rates to obtain the best fit of computed versus observed heads, suggest that as long as the water level remains below the trench covers, water from the trench will not intersect the stream. Details of calibration of this vertical section are presented in Prudic (1981). The maximum outward distance that trench water would migrate through the upper weathered till, assuming the water level in trench 4 to be constant and near the top of the trench indefinitely, is about $8 \mathrm{~m}$ before it would move downward into the unweathered till. The calculated head distribution and flow paths of water from trench 4 westward when the water level is near the cover is shown in figure $20 B$.

Simulations were also made along vertical section D- ${ }^{\prime}$ through the south trenches, assuming the trenches to be filled with water. Under these conditions, the maximum distance that water would flow eastward from trench 8 and westward from trench 14 through the weathered zone is between 5 and $10 \mathrm{~m}$, not nearly far enough to intersect Franks Creek (fig. 21).

\section{SEEPAGE THROUGH A HYPOTHETICAL PERMEABLE LAYER}

Despite a lack of evidence of any continuous layer of permeable silt and sand extending from a trench to a nearby stream (discussed in section "Lenses of sorted material"), two trial simulations incorporating this condition were made. In the first simulation, the model in- corporated a permeable layer approximately $2 \mathrm{~m}$ thick extending from beneath trench 8 to Franks Creek along the same vertical section as modeled previously (fig. 21), assuming a hydraulic conductivity of $6 \times 10^{-8} \mathrm{~cm} / \mathrm{s}$ for the unweathered till. The hydraulic conductivity of the permeable layer was set at $6 \times 10^{-6} \mathrm{~cm} / \mathrm{s}$, which is at the upper range of the estimated hydraulic conductivity for distorted silt and sand lenses as determined from slug tests of piezometers. The infiltration rates from trench 8 eastward to Franks Creek were the same as those used in the calibration of February 1978 water levels, and the constant head in trench 8 was set equal to the observed head of February 1978. This simulation indicated that water leaving trench 8 would travel about $10 \mathrm{~m}$ outward from the trench, then almost vertically downward in the till, as indicated in figure 22. Discharge from this hypothetical permeable layer to Franks Creek would consist mainly of precipitation that had infiltrated through the till along the slope and then into the permeable layer. In the second simulation, trench 8 was assumed to be filled with water; under such conditions water from trench 8 would travel as much as $18 \mathrm{~m}$ outward through the hypothetical layer before it would move vertically downward, but still it would not approach Franks Creek (fig. 22).

\section{ESTIMATED TRAVELTIME}

Prudic and Randall (1979, p. 881) estimated that the traveltime for a water particle leaving a trench to reach the slope near Buttermilk Creek would be about 400 years. (In that report the hydraulic conductivity of the underlying lacustrine sequence was incorrectly stated as $1 \times 10^{-2} \mathrm{~cm} / \mathrm{s}$; the value actually used was $1 \times 10^{-4}$ $\mathrm{cm} / \mathrm{s}$.) From the information presented below, the traveltime is estimated to be from 800 to 2,800 years.

Water moving downward through the approximate $23 \mathrm{~m}$ of till beneath the trenches would take from 300 to 2,300 years to reach the underlying lacustrine sequence, assuming a specific flux of 0.3 to $2.3 \mathrm{~cm} / \mathrm{yr}$ as determined from computer simulations using a uniform hydraulic conductivity of the till between $2 \times 10^{-8} \mathrm{~cm} / \mathrm{s}$ and $6 \times 10^{-8} \mathrm{~cm} / \mathrm{s}$ and an effective porosity of 0.3 . Calculation of specific flux from the migration of tritium at four locations beneath trenches 4,5 , and 8 (see section "Radionuclide migration from trenches") ranged from $0.3 \mathrm{~cm} / \mathrm{yr}$ to $1.2 \mathrm{~cm} / \mathrm{yr}$ and depended on the amount of sorted material encountered in the test holes and the water level in the trenches. These values are within the range calculated from computer simulation of groundwater flow.

A water particle would take at least another 500 years to travel the $840 \mathrm{~m}$ northeastward along a flow path (fig. 15), assuming a hydraulic conductivity of 
A

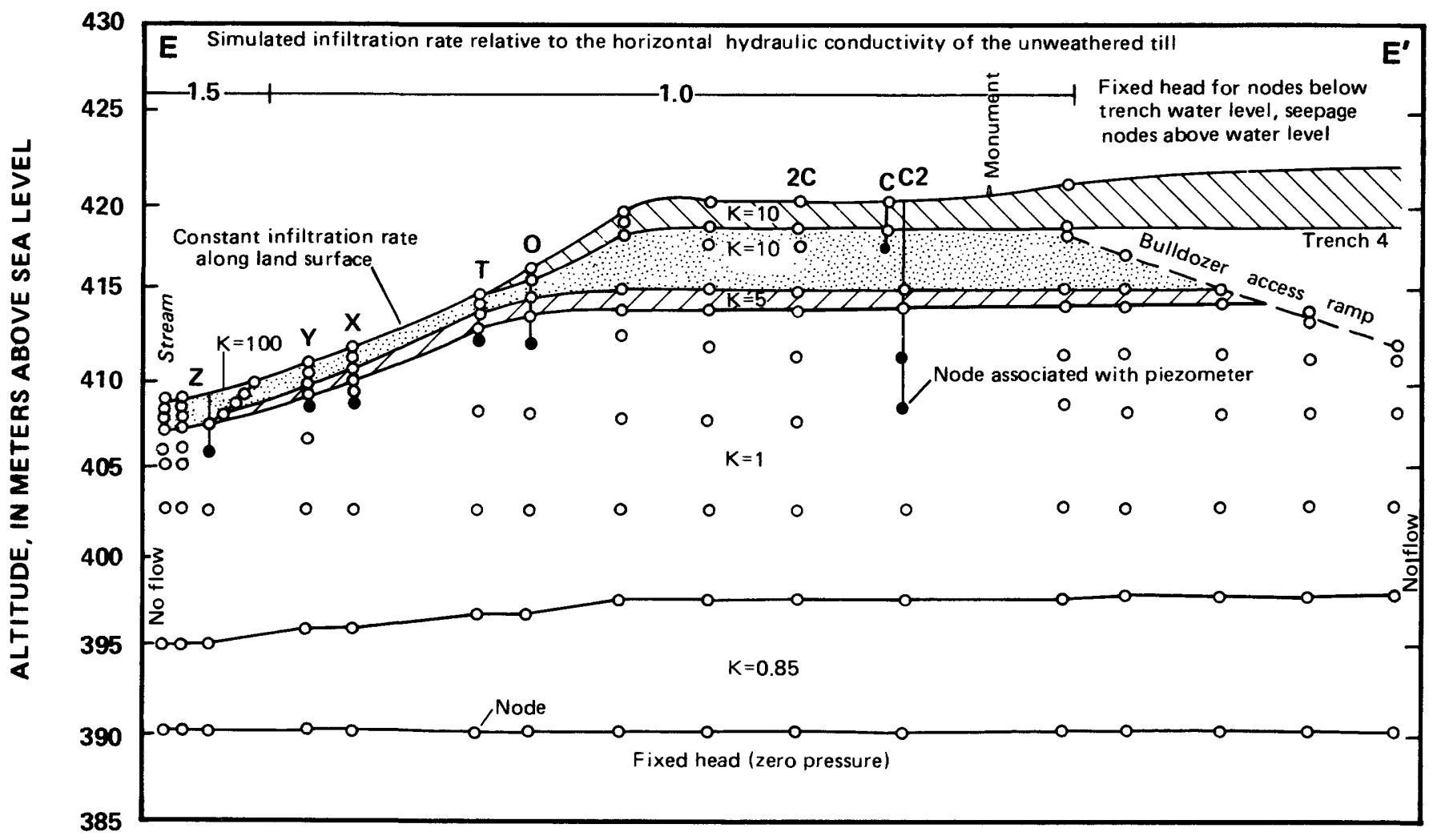

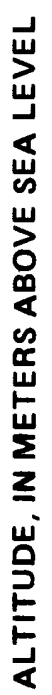

B

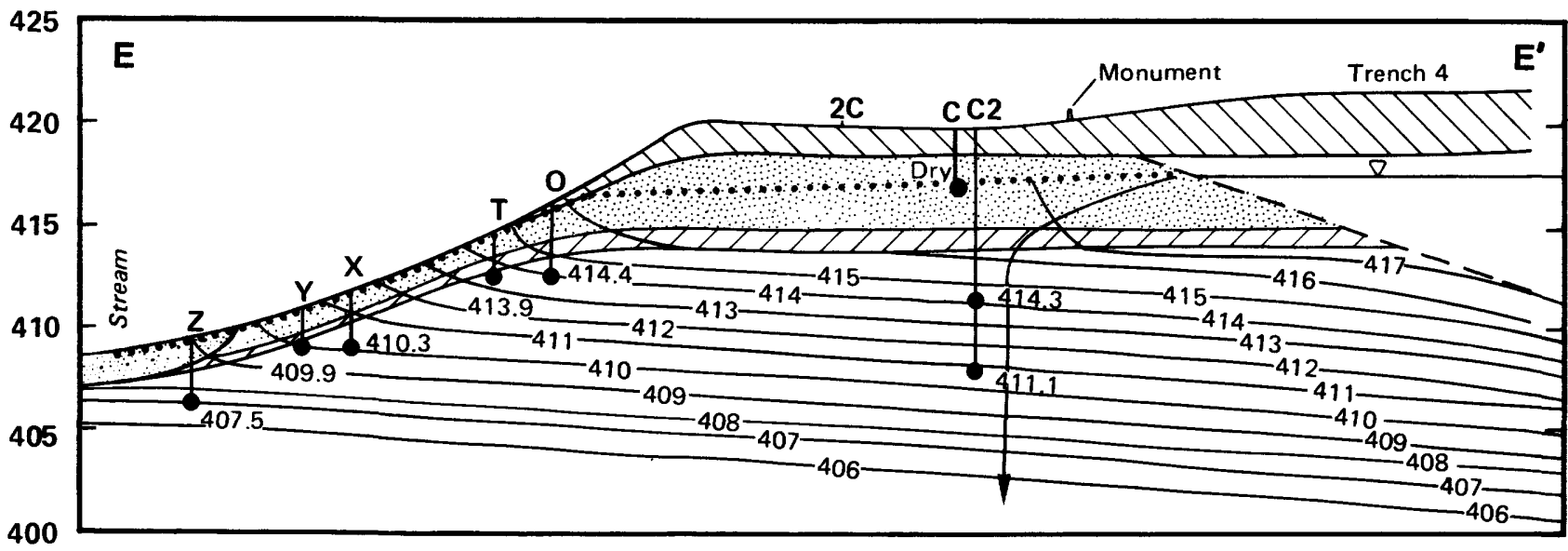

EXPLANATION

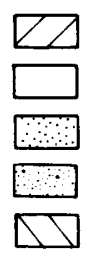

Unweathered till with oxidized fractures
Unweathered till
Weathered till
Alluvium

Backfill

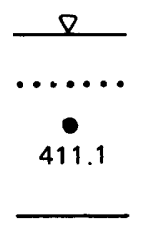

20

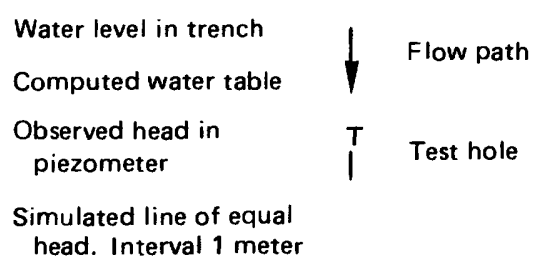

Simulated line of equal
head. Interval 1 meter

FIGURE 20.-Vertical section $\mathrm{E}-\mathrm{E}^{\prime}$ from trench 4 northward to small stream. A, Node arrangement, boundary conditions, and relative hydraulicconductivity values and relative infiltration rates used in the best-fit simulation. $B$, Computer-simulated distribution of heads for February 1976. Location of section is shown in figure 7 (from Prudic, 1981). 
$1 \times 10^{-4} \mathrm{~cm} / \mathrm{s}$ as a reasonable value for silt; an effective porosity of 0.25 , and a gradient of $0.013 \mathrm{~m} / \mathrm{m}$ based on head measurements of three piezometers. The time estimate is only tentative because the hydraulic conductivity of the lacustrine sequence was not determined from field or laboratory tests but was obtained from a table such as the one in Freeze and Cherry (1979, p. 25). The hydraulic conductivity of a silt could be between $1 \times 10^{-2}$ and $1 \times 10^{-6} \mathrm{~cm} / \mathrm{s}$, in which case the estimate of traveltime could be from 5 to 50,000 years. However, field observations of the silt suggest that hydraulic conductivity is probably closer to $1 \times 10^{-4} \mathrm{~cm} / \mathrm{s}$ than either $1 \times 10^{-2}$ or $1 \times 10^{-6} \mathrm{~cm} / \mathrm{s}$. In addition, the time required for a water particle to move vertically through the $3 \mathrm{~m}$ of unsaturated lacustrine deposits beneath the till should be less than through an equal depth of till; however, the rate cannot be estimated because neither the percent moisture content nor the unsaturated hydraulic conductivity of the silt is known.

\section{REGHARGE TO TRENCHES}

Perhaps the most significant concern with the burial ground in regard to the movement of radionuclides in the liquid phase has been the gradual rise of water in several of the trenches and the eventual overflow of that water through the covers of some. Water levels in all trenches have been monitored regularly since 1966 by Nuclear Fuels Services, Inc. Figure 23, based on their data to 1975 and compiled in part by E. J. Michael (New York State Department of Environmental Conservation, Bureau of Radiation, written commun., 1974), shows that all but trench 8 had a modest water-level rise shortly after completion. During the 1971 summer, water levels in trenches 3 through 5 began a persistent rise, and by March 1975, trench water had begun to seep out through the cover to land surface along the west side of trench 5 and the north end of trench 4 (Kelleher, 1979; Prudic and Randall, 1979, p. 862). From 1975 through

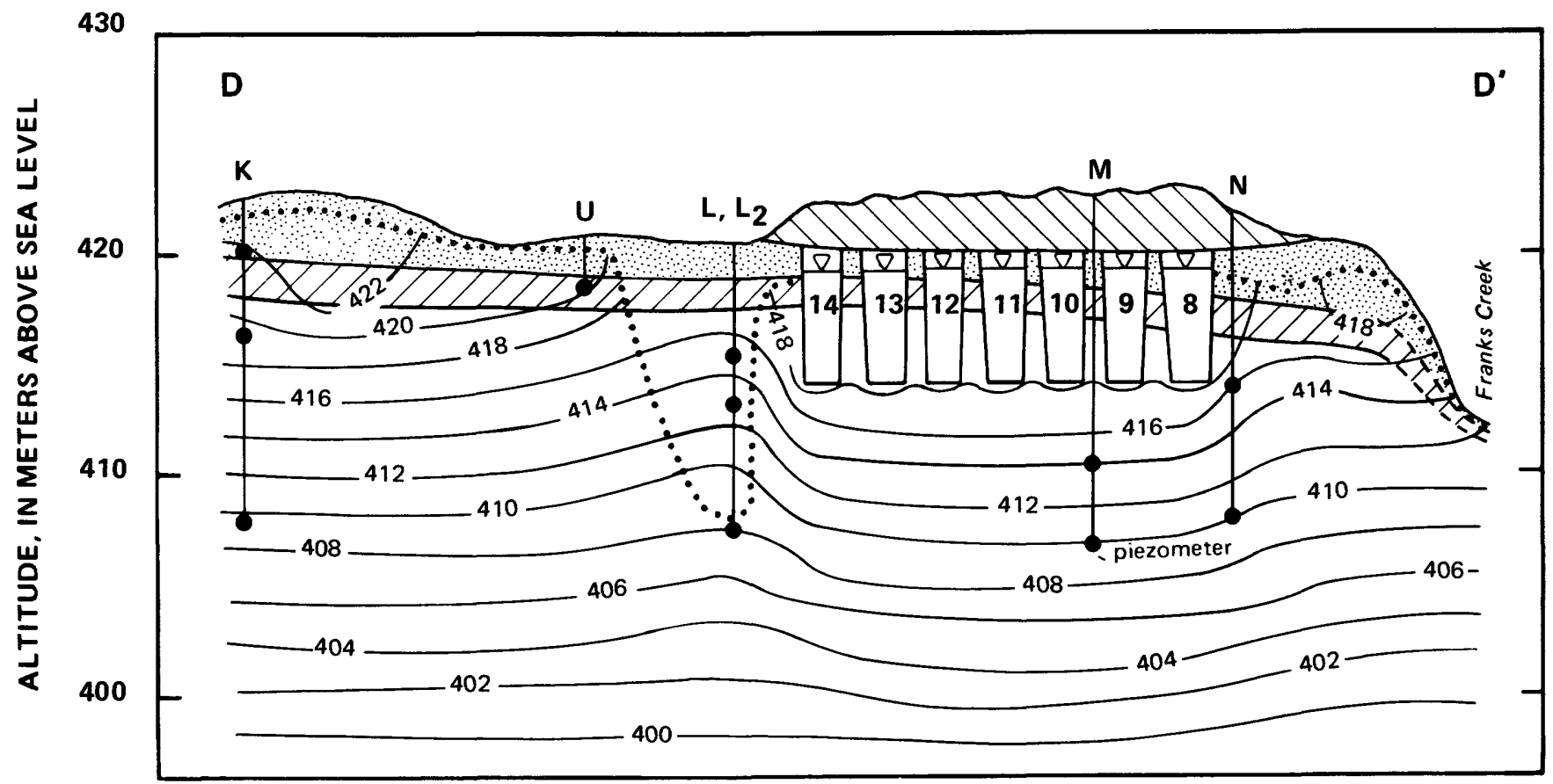

EXPLANATION

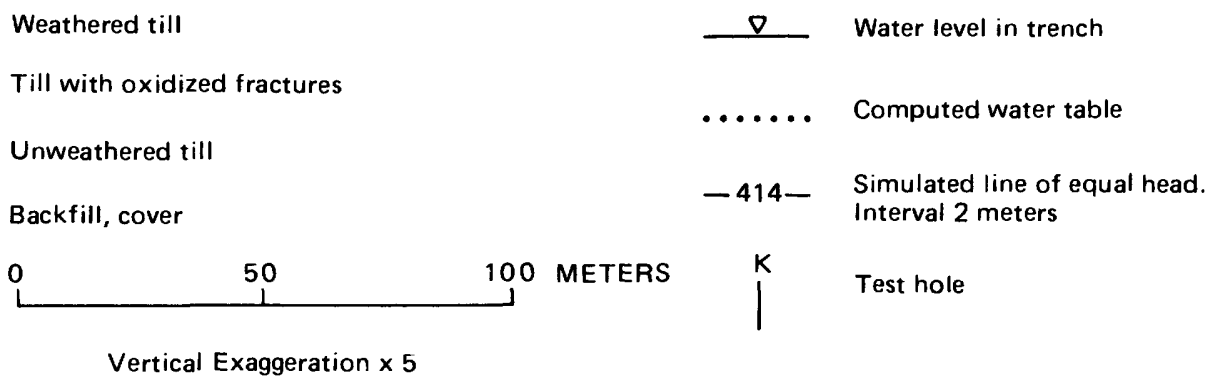

FIGURE 21.-Vertical section D-D' through south trenches showing computer-simulated distribution of head, and assuming trenches to be filled with water. 
A

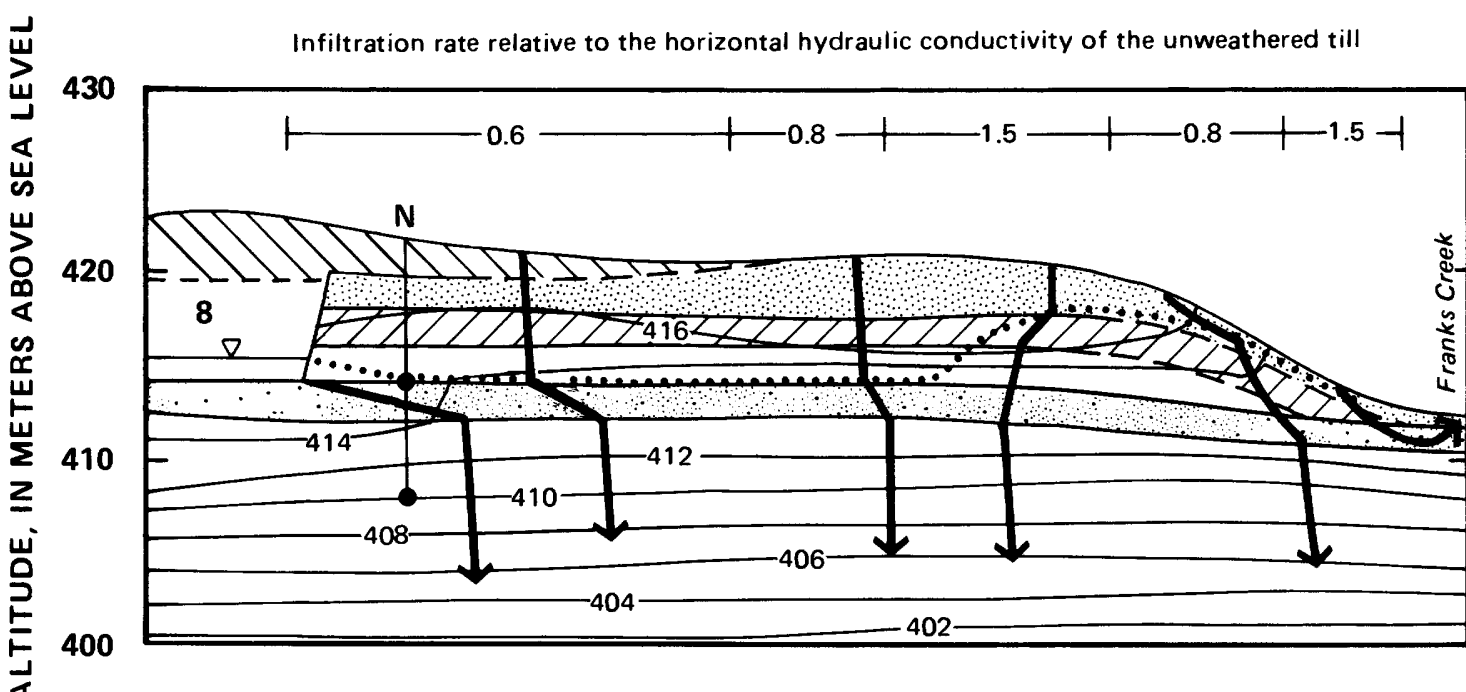

$D^{\prime}$

B

430

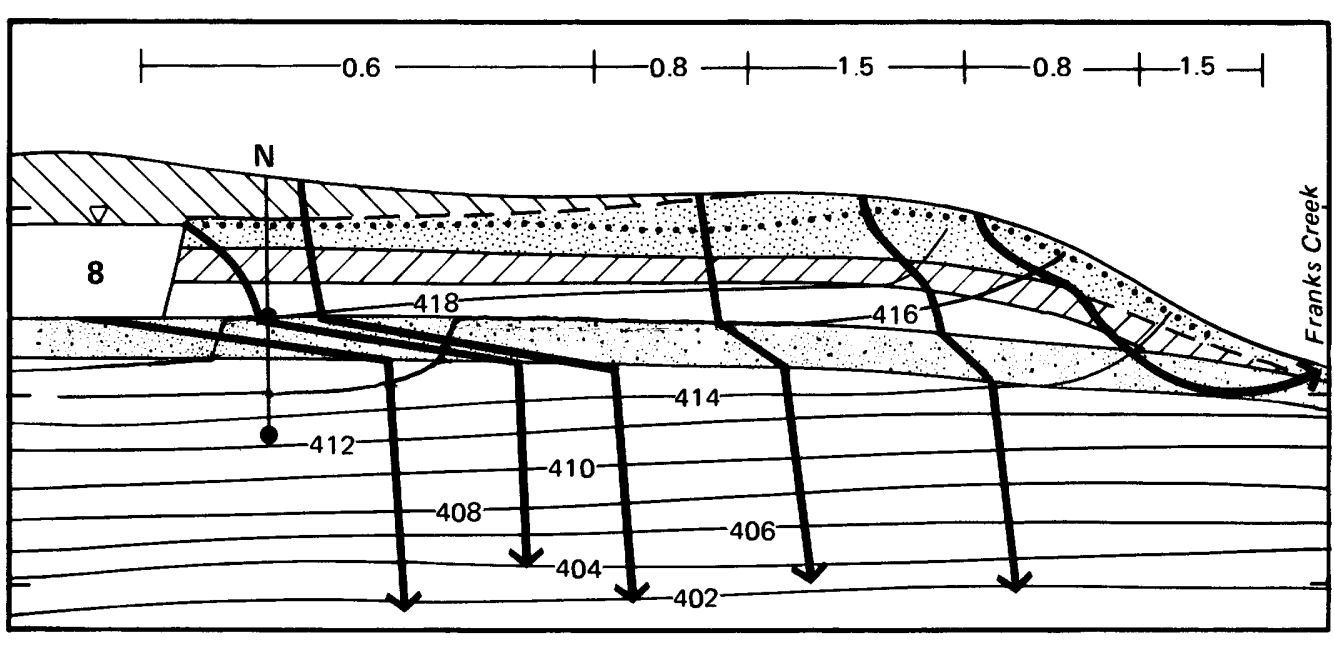

D'

EXPLANATION

$\begin{array}{ll}\square & \text { Till with oxidized fractures } \\ & \text { Unweathered till } \\ \square & \text { Silt and sand } \\ \square & \text { Backfill, cover } \\ \square \text { Wlowhered till }\end{array}$

$10 \quad 20$ METERS

FIGURE 22.-Part of vertical section D-D' from trench 8 eastward to Franks Creek showing computer-simulated distribution of head, and assuming a permeable layer from trench to stream. A, Trench water at observed February 1978 level. $B$, Trench nearly filled with water. Location of section is shown in figure 7 . 
1976 , the site operator removed much of the water from trenches 2 through 5 by pumping it into temporary holding ponds near the trenches, then to the wastetreatment plant near the reprocessing plant. From August through October 1978, water levels in these trenches rose again (fig. 23), probably as a result of waste compaction after at least $1.3 \mathrm{~m}$ of cover was added over trenches 1 through 5 during August 1978. Most of the south trenches (8-14) had maintained nearly constant water levels from the time of their completion through the dry summer of 1978 , after which water levels in trenches 11 through 14 rose noticeably (fig. $23 B$ ). Several investigators (Matuszek and others, 1976; Giardina and others, 1977; Kelleher, 1979; Prudic and Randall, 1979; and Prudic 1979b and 1980) have concluded that the water-level rise in many of the trenches was due to infiltration of precipitation through the covers rather than ground-water seepage and that differences in cover permeability among the trenches caused the differences in water-level trends. For several reasons it has been concluded that ground-water seepage could not have caused the rising water levels:

1. Piezometers near the trenches show that groundwater gradients are downward and outward from

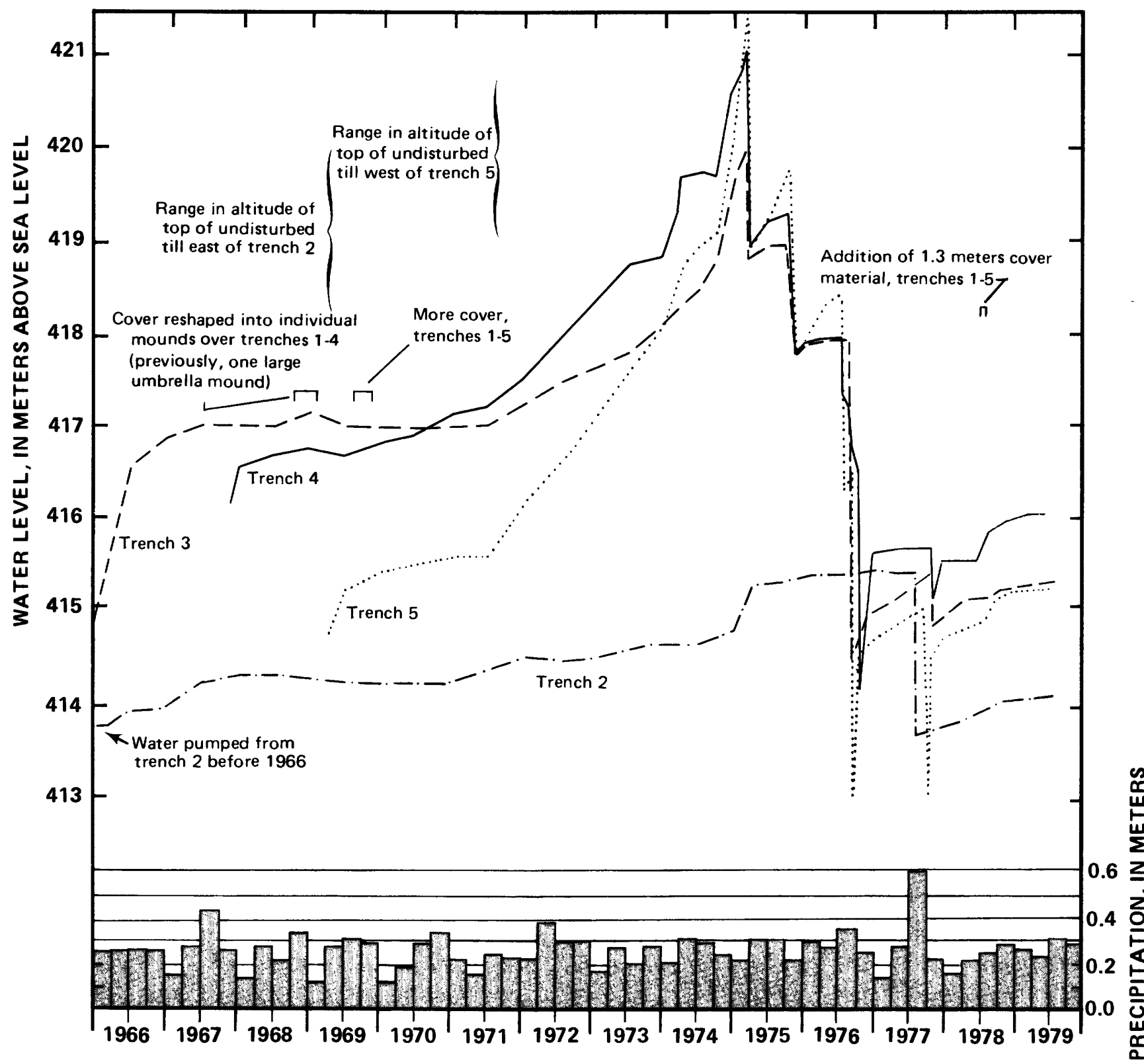

FIGURE 23.-Water-level trends in trenches, 1966-79. $A$, Trenches 2-5, 1966-79. Abrupt downtrends are due to removal of water by pumping. Location of trenches is shown in figure 7. 
the trenches except in a small region near land surface immediately west of trench 5 (see section "Flow within the till" or Prudic and Randall, 1979, and Prudic 1981).

2. There is no reason to postulate gradients toward the trenches in the past or between piezometers. Even if such gradients existed, the low hydraulic conductivity of the till would prevent water from moving into the trenches fast enough to cause the observed rises in trench-water level.

3 . Trenches 5 and 14, the two westernmost trenches, are the most likely to be affected by ground-water inflow because land surface rises to the west of the site, and Franks Creek and its tributaries are below the altitude of the trench floors immediately to the north and east (fig. 2). However, in 1971-73, water levels were higher in trenches 3 and 4 than in trench 5 and were rising rapidly (fig. $23 \mathrm{~A}$ ), and in 1978-79, water levels in trenches 12 and 13 rose rapidly to levels higher than in trench 14 (fig. 23B). Furthermore, water levels in trenches 5 and 14 have shown unsteady, commonly stepwise upward trends that corresponded more closely to precipita- tion patterns than to water-level fluctuations in piezometers finished in the till nearby, as explained in the following section.

4. During 1974-75, water levels in trenches 3 through 5 rose into the cover, higher than the surrounding land surface. Ground-water heads have never been known to exceed land-surface altitude anywhere near the trenches.

\section{CORRELATION OF PRECIPITATION WITH WATER-LEVEL RISES IN TRENCHES}

A water-level recorder was maintained on the sump in trench 5 from May 1975 through December 1979, and one to three other recorders were moved from one trench to another during this time to document the water-level rises in the trenches. In addition, a precipitation gage was installed $340 \mathrm{~m}$ to the west (near well 54-11 in fig. 2 ). The correlation of the hydrographs with precipitation records was complicated by water-level fluctuations as large as $15 \mathrm{~cm}$ in some sumps in response to

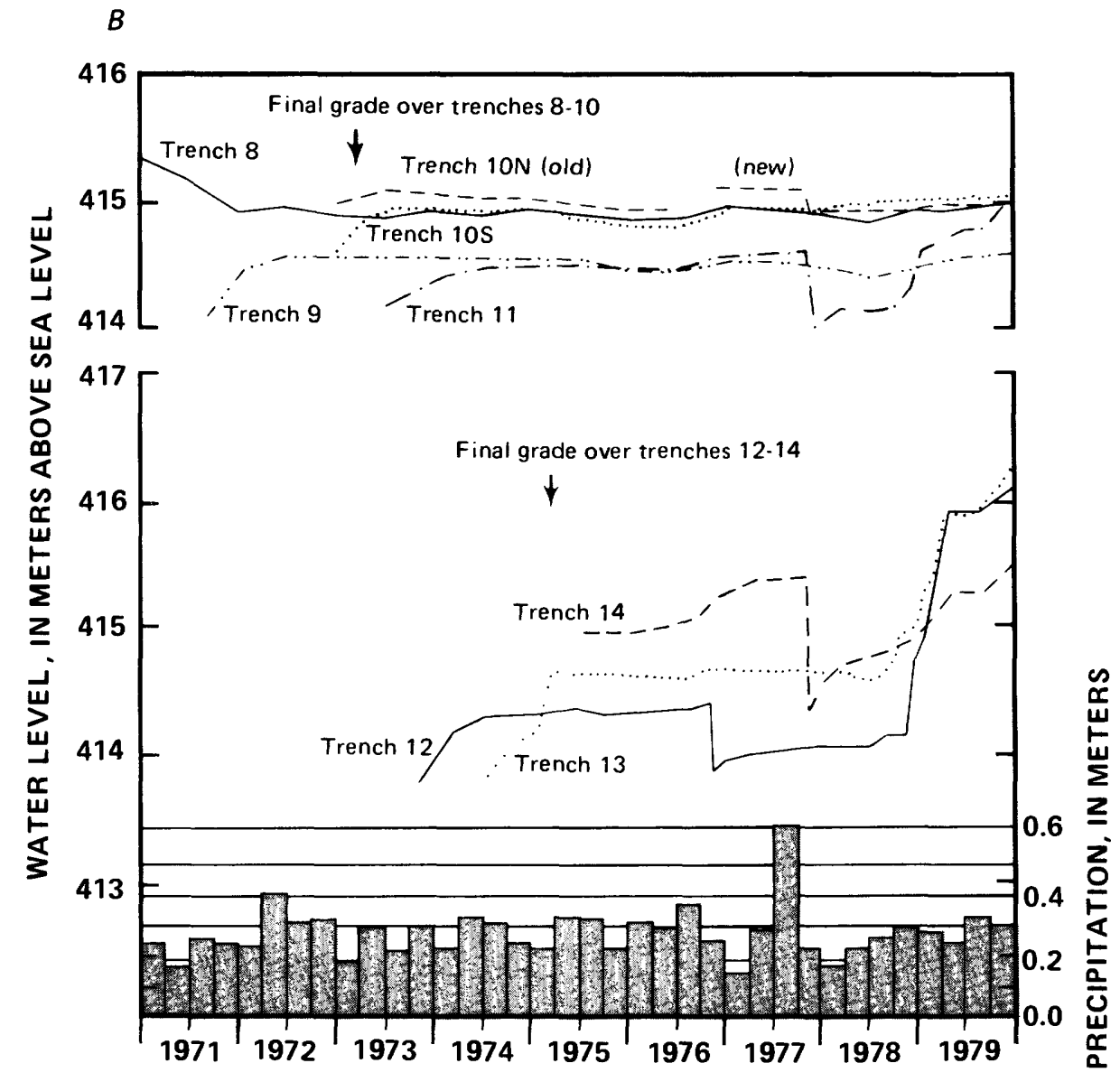

FIGURE 23.-Continued.Water-level trends in trenches, 1966-79. B, Trenches 8-14, 1971-79. Abrupt downtrends are due to removal of water by pumping. Location of trenches is shown in figure 7 . 
barometric-pressure fluctuations. The ratio of change in water level to change in barometric pressure (barometric efficiency) was nonlinear. The ratio was greater during large, abrupt barometric fluctuations than during small, gradual ones. This nonlinear response probably is a result of air moving into and out of the trenches, through cracks in the cover or openings along sump standpipes above trench-water level-a process that gradually equalizes any imbalance between trench-gas pressure and fluctuating atmospheric pressure at rates that apparently are a significant fraction of slow barometric changes. Despite this complication, it was often possible to demonstrate that abrupt, small rises in trenchwater levels corresponded to individual precipitation events and that seasonal average rates of rise correlated with precipitation trends.

The hydrograph for trench 5 from May through September 1975 (fig. 24A) was corrected to a constant atmospheric pressure by determining the average

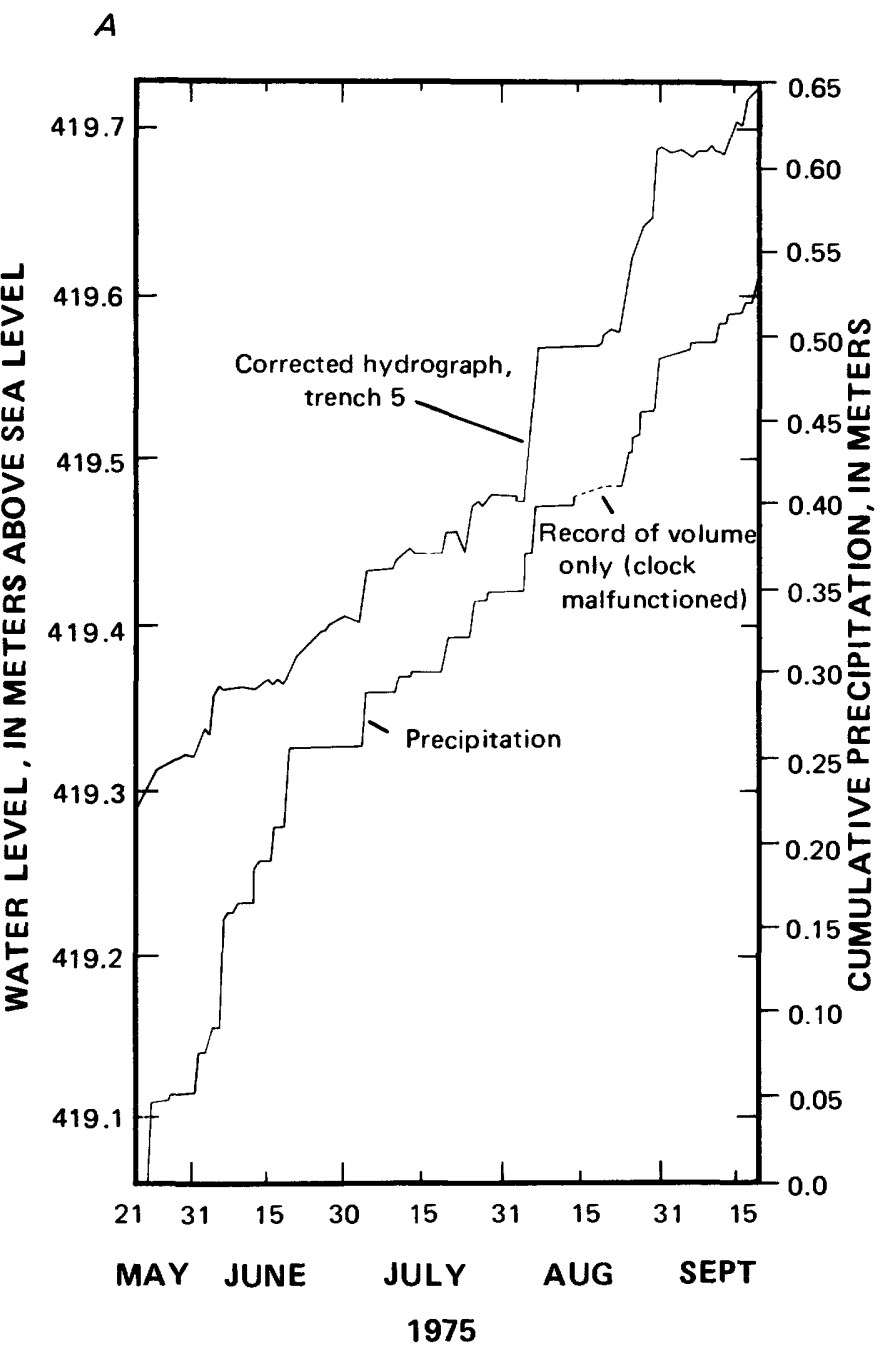

barometric efficiency over short time intervals and then adjusting the water levels; the result is plotted against precipitation. In May and June, the water levels in sump 5 rose almost continuously but showed little correlation with precipitation. From July 1 to September 11, however, individual water-level rises corresponded closely to precipitation. The ratio of water-level rise to precipitation increased about August 1, and at the same time, the barometric efficiency increased from 28 to 40 percent (Prudic and Randall, 1979, p. 867). This increase in rate of water-level rise could have been due either to a greater percentage of precipitation reaching the trenches or to the rise of trench water into the cover. Because the cover has fewer large void spaces than the waste, any volume of recharge would saturate a greater thickness of the cover (Prudic and Randall, 1979, p. 867). This increase in rate took place as the water level rose above an altitude of $419 \mathrm{~m}$, the approximate level of the base of the cover (Prudic, 1980).

A hydrograph corrected to a constant atmospheric pressure from January through July 1976 is shown in figure $24 B$. The barometric efficiency during this time averaged about 20 percent, about half that measured between August and September 1975. This is consistent with the lowering of the water level to below the cover, which occurred between September and October 1975 when the site operator pumped water from the trench and lowered the water level to an altitude of about 418

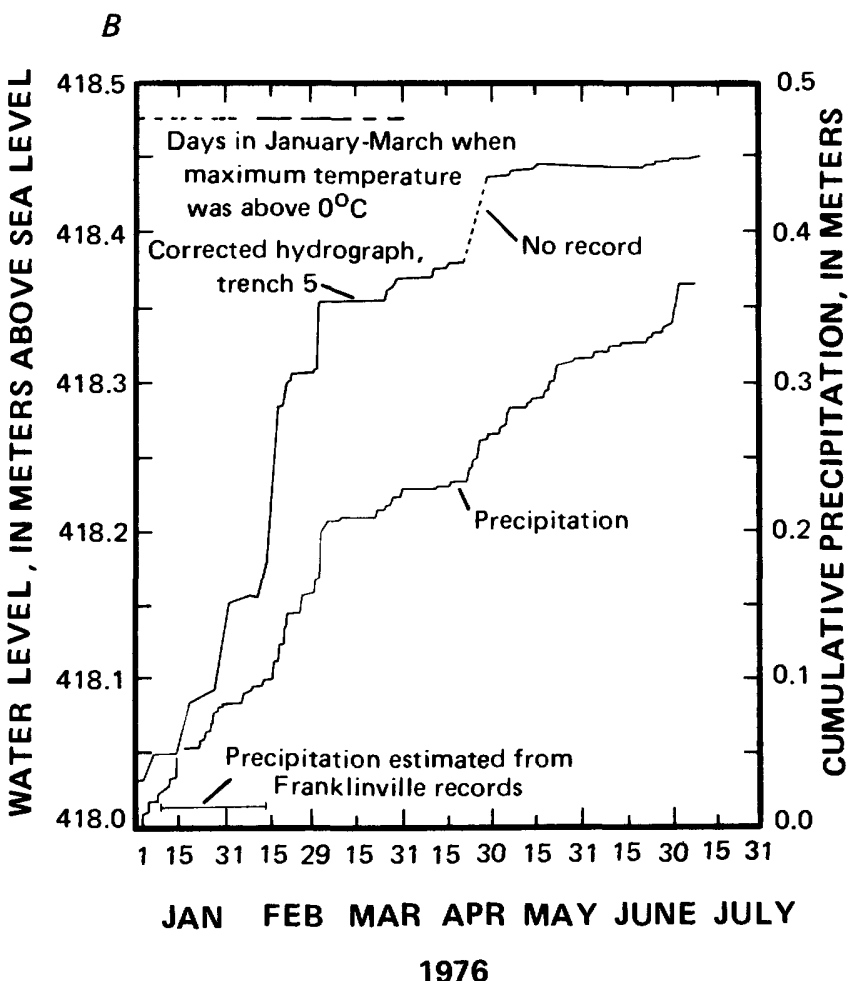

FIGURE 24.-Water level in trench 5 in relation to precipitation (hydrograph corrected to remove effects of barometric fluctuations). A, May through September 1975 (from Prudic and Randall, 1979). B, January through July 1976. Location of trench 5 is shown in figure 7. 
m. From January to April 1976, the water level in trench 5 rose sharply during most precipitation events, and the average rate of rise was similar to that in August to September 1975. The large rises in water levels in February 1976 correspond to extended periods in which the maximum daily temperature (recorded at nearby Franklinville) exceeded $0^{\circ} \mathrm{C}$, and especially during at least 7 of the last 20 days in February, when maximum daily temperatures exceeded $10^{\circ} \mathrm{C}$. The large water-level rises (including those in January) may have been caused by the melting of snow already on the ground and were augmented by rain.

The correlation between precipitation and water-level rise in trench 5 was poor from May through June 1976 (fig. $24 B$ ), even more so than during the same period in 1975 (fig. 24A). Evapotranspiration may have consumed a large fraction of the precipitation from May through July 1976, which was half the precipitation recorded for May through June 1975. In addition, it is possible that the amount of void space in the trench increased between the altitudes of 418.4 and $418.5 \mathrm{~m}$, but this is unconfirmed.

The initial recovery of the water level in trench 5 after water was pumped out in 1976 and 1977 responded in a manner similar to most wells after pumping-recovery was rapid immediately after the pumping stopped, then slowed with time. After the initial recovery, the water level rose consistently but did not correlate with individual precipitation events. A plot of water-level rises from 1976 to 1978 is given in figure 25 . One explanation is that the slug of water infiltrating downward through the cover was attenuated as it moved through the unsaturated wastes such that it reached the water level in the trench at a relatively constant rate.

Barometric fluctuations in the hydrograph of trench 5 (fig. 25) after the water level was substantially lowered in 1976 were most common between November and May. The lack of barometric fluctuations in the summer suggests that the movement of air through the cover during periods of change in atmospheric pressure was more rapid in summer than in winter and spring. Prudic (1980) noted that changes in gas pressure in the unsaturated parts of several trenches responded more rapidly to changes in atmospheric pressure during the summer and fall than during winter and spring. Seasonal changes in the rate of movement of air through the cover may have been caused by the enlargement of cracks in the cover through drying in summer, followed by closing of those cracks during the winter by swelling, sealing with ice or water, or a covering of nearsurface mud. The rate of water-level rise in trench 5 did not increase in summer, however. Perhaps the open cracks were chiefly along the crest of the mounds and captured little recharge owing to their position. This would explain the lack of increased recharge at the same time as the absence of water-level fluctuations due to barometric changes during and after summer storms.

Water levels began to rise in trenches 11 through 13 (Prudic, 1979b) after the dry summer of 1978, and a continuous water-level recorder was installed on trench 12 in March 1979. A hydrograph and precipitation graph for March 1979 through January 1980 is shown in figure 26. During March and April 1979, the water level in trench 12 rose at a rate considerably greater than the rate of precipitation, as indicated in figure 26 , which may reflect infiltration of snowmelt. A rectangular subsidence hole was discovered about $75 \mathrm{~m}$ south of the north end of trenches 11 and 12 and along the drainage divide between those trenches. The hole captured much of the runoff from the northern part of trenches 11 and 12. After this hole was filled by the site operator in April 1979 , the water-level rise essentially ceased. Although the hole had probably contributed greatly to the waterlevel rise in trench 12 , no holes were found on trenches 11,13 , or 14 , in which water levels had also risen rapidly from November 1978 through August 1979 (fig. 26A). The rapid rise of water levels in trenches 11 through 14 was probably caused by infiltration of precipitation through cracks in the cover. The origin of these cracks is discussed in the section "Infiltration of precipitation through cracks in cover."

Even after the subsidence hole was plugged, water infiltrated through the cover of trench 12 , as evidenced by the water-level increases that in general correspond to precipitation events from May through September 1979. A noticeable rise in the water level occurred after a storm during the middle of September (fig. 26A), and a similar pattern was observed in trench 14 during the same period (fig. 26B). From October 1979 through January 1980, the water level rose steadily in both trenches 12 and 14 without any direct correlation with precipitation.

After the dry summer of 1978 , water levels rose in trenches 8 through 10 (fig. $23 B$ ) but at a much slower rate than in trenches 11 through 14 . The reasons are not understood. Measurements of the rate at which air moved through the trench cover in response to barometric-pressure fluctuations (Prudic, 1980; Lu and Matuszek, 1978) indicated that in July 1978 the cover over trench 8 was just as permeable as that over trenches 11 and 12. Maximum cover permeability and recharge might be expected in trenches having the greatest potential for collapse of waste. However, as shown in table 3 , trenches 8 and 9 contain larger amounts of waste than later trenches, contain slightly more cardboard and fiberboard containers, and have had more time for decay, all of which would seem to favor more rapid collapse and development of subsidence 


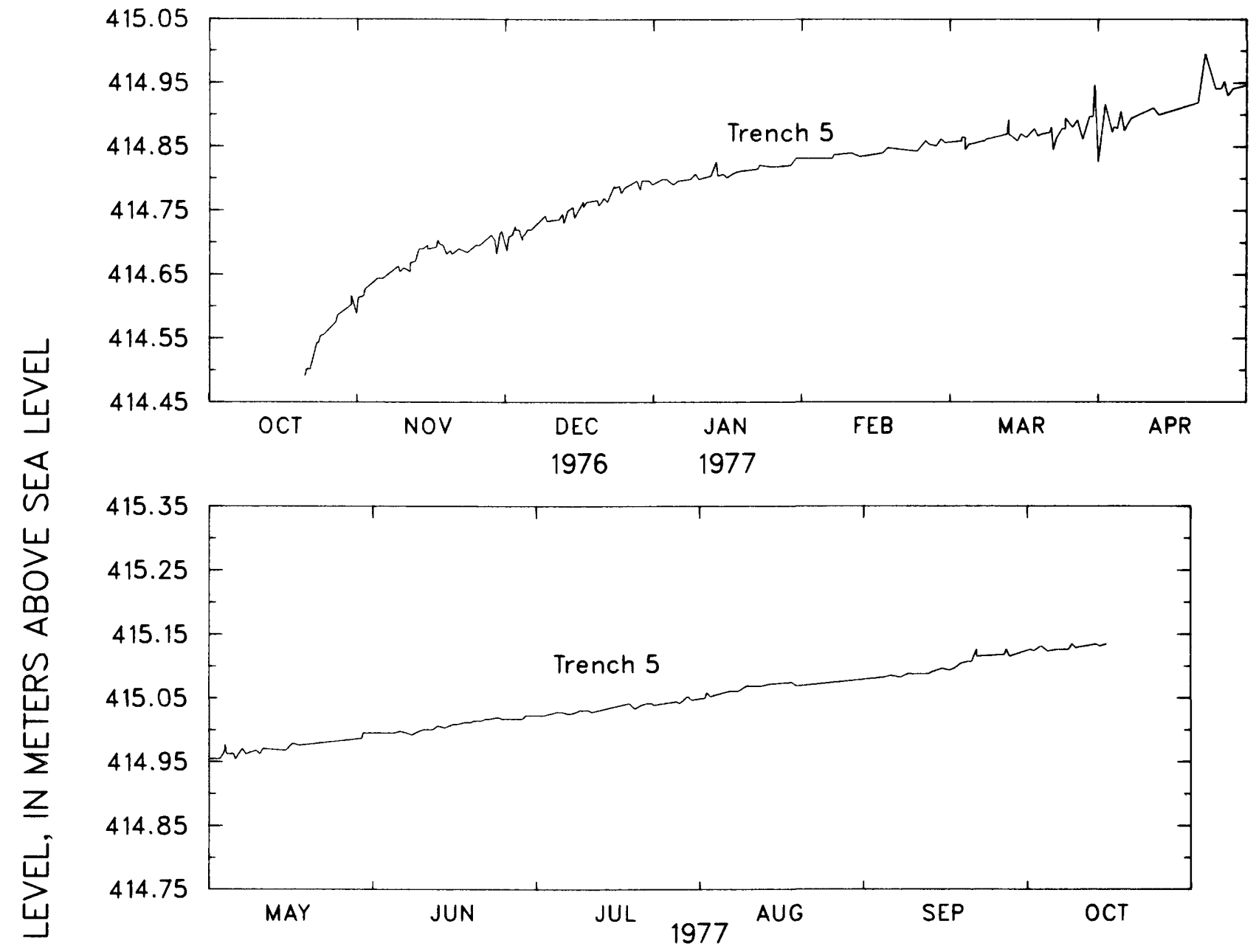

品

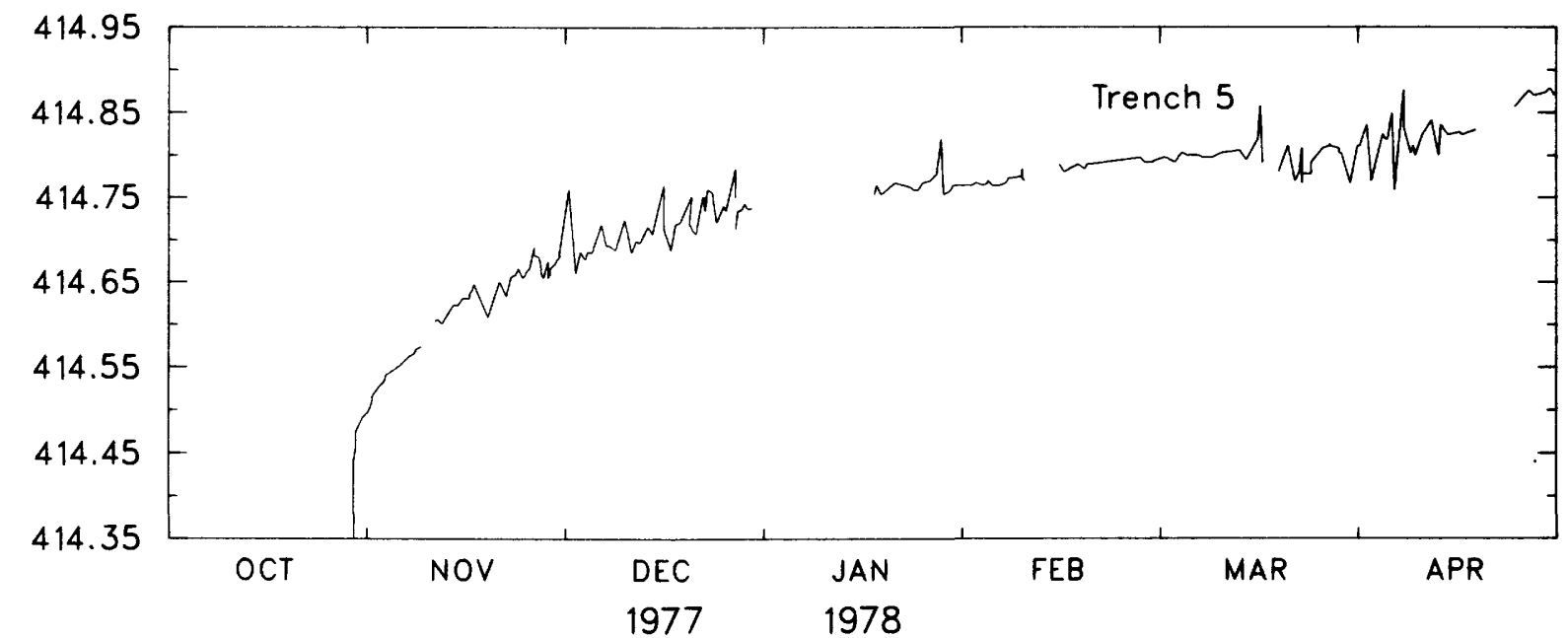

FIGURE 25.-Water level in trench 5 after pumpout of water in July and September 1976 and November 1977. Trench location is shown in figure 7 . 
cracks than in the later trenches. Possibly the cardboard and fiberboard containers were already largely compressed before the final cover grade was established owing to the weight of heavy machinery and temporary surcharge of till excavated from the next trench.

If the covers over trenches 11 through 13 were thinner than the rest, they might be more susceptible to breaching by cracks. Comparison of a topographic map prepared for the site operator in 1970, after topsoil was removed but before excavation of the south trenches began, with a similar map of the completed trenches in 1977 and with logs of nearby test holes suggests that the cover over trenches 8 through 10 may be $30 \mathrm{~cm}$ greater than at trenches 11 through 13 and $60 \mathrm{~cm}$ thicker than at trench 14 . However, data from pipes driven through the cover near the south end of the trenches suggest little difference in cover thickness between trenches 8 through 10 and trenches 11 through 13. After data on the driving of pipes through the cover near the south end of each trench were evaluated, average cover thickness at trenches 8 through 13 was estimated to be $3.3 \mathrm{~m}$ and at trench 14 only $2.7 \mathrm{~m}$ (Prudic, 1980, table 1). If these estimates are correct, they help explain the rise in water level in trench 14 but not the stable levels in trenches 8 through 10 .

Prudic (1980) postulated that water levels in trenches 8 through 10 failed to rise not because the covers were

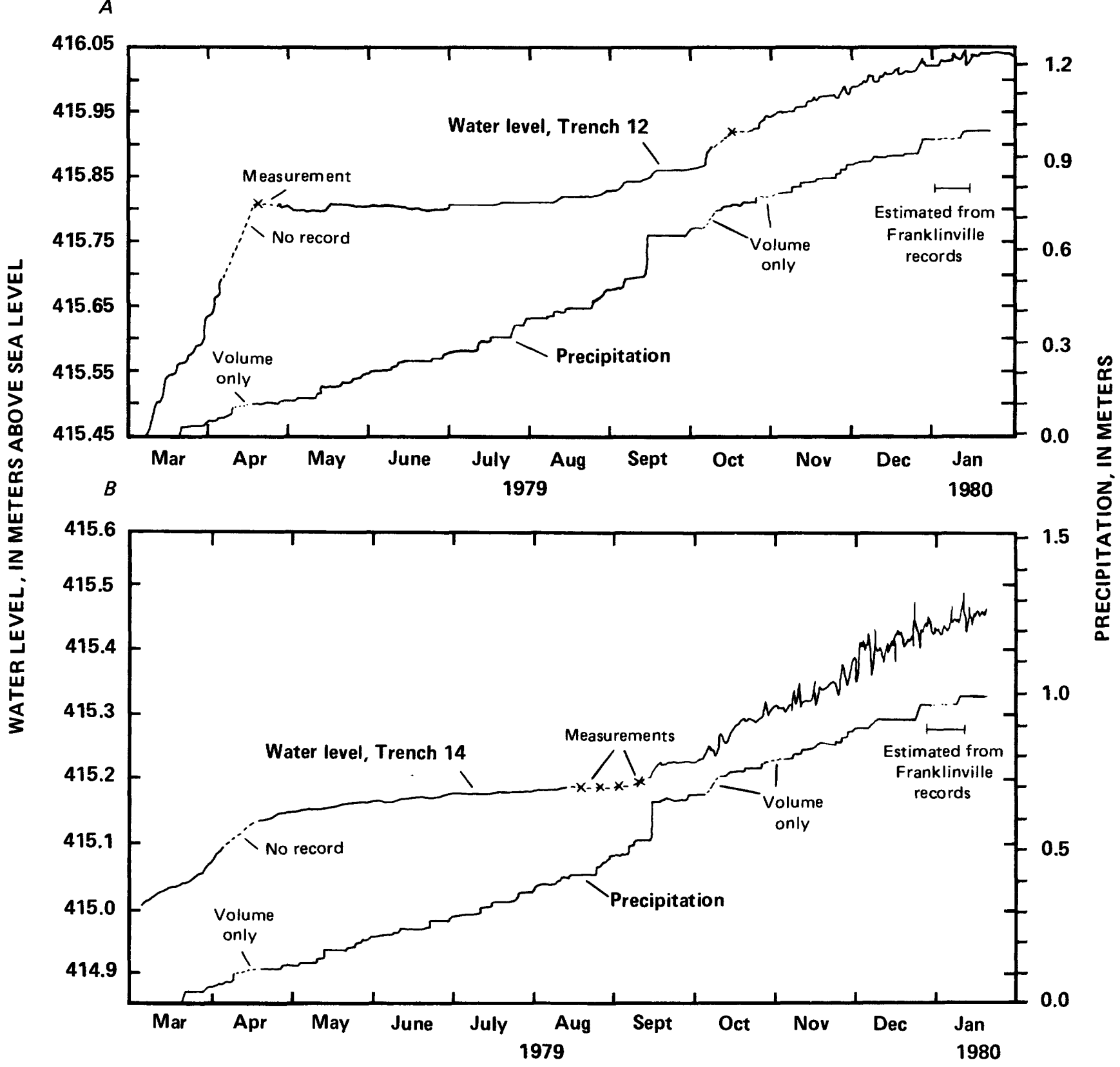

FIGURE 26.-Water level in trenches 12 and 14 in relation to precipitation, March 1979 through January $1980 . A$, Trench $12 . B$, Trench 14. Trench locations are shown in figure 7. 
intact but because recharge was balanced by outward seepage of water along silt and sand lenses known to be present beneath part of trench 8 . However, these lenses are small and do not short circuit the downward flow of water through the till (discussed in the section "Lenses of sorted material"). Also, the absence of abrupt water-level rises from rapid recharge through the trench covers after individual storms, followed by gradual declines in the water levels due to seepage out of the trench makes this explanation unlikely. Thus, the reasons for the stability of water levels in trenches 8 through 10 are as yet unknown.

\section{EFFECTS OF ADDITIONAL COVER OVER TRENCHES 1 THROUGH 5 ON WATER LEVELS}

The covers over trenches 1 through 5 were regraded August 7 through 13,1978, to reduce or eliminate infiltration of rain and snowmelt into the trenches. First, the topsoil mantling the surface was scraped away, and the underlying material was compacted with heavy machinery. At least $1.3 \mathrm{~m}$ of reworked till from an area east of trench 8 between Franks Creek and Buttermilk Creek (fig. 2) was then added and compacted. The water level in trench 5 rose almost immediately, presumably as a result of compaction of the waste; however, after the work was completed, the water level continued to rise until at least October 1978 in a pattern similar to that during the first days after a pumpout (fig. 27). A similar rising trend was noted at trenches 2 through 4 . This continued rise is unexplained but may have resulted from the slow drainage of previously saturated or nearly saturated waste perched at high levels in the trench.

The water level in trench 5 rose only $5 \mathrm{~cm}$ (fig. 27) from January through September 1979, in contrast to its rise of at least $35 \mathrm{~cm}$ during the same months in 1977 before the cover was reworked. Although precipitation during the 1979 period was $17 \mathrm{~cm}$ less than during the 1977 period, this does not account for the sevenfold decrease in water-level rise. Similar decreases in rate of water-level rise were observed in trenches 2 through 4 after the covers were regraded. It is therefore concluded that the recompaction and increased thickness of cover material reduced the rate of water-level rise in the trenches, a conclusion which supports other evidence that the principal cause of water-level rises in the trenches is infiltration of precipitation through the cover.

\section{INFILTRATION OF PRECIPITATION THROUGH CRACKS IN COVER}

A network of intersecting cracks was visible on the surface of the trench covers from the beginning of the study. Although most cracks became obscured or filled with mud after thaws during the winter and early spring, new cracks reappeared each year, commonly in the same position and shape, suggesting permanent lines of weakness. The cracks tended to be alined parallel and transverse to the trench axis (Dana and others, 1978; Prudic and Randall, 1979). During dry periods, some cracks were as wide as $5 \mathrm{~cm}$ at land surface (Dana and others, 1979), and a steel tape could be pushed to depths of $30 \mathrm{~cm}$ in many places and $60 \mathrm{~cm}$ locally (Prudic, 1980). On the hypothesis that the cracks might be avenues through which water could enter the trenches, 2,000 L of water was siphoned into two sets of cracks at the south end of trenches 4 and 5 in September 1975. No surface outflow resulted, which suggests that these particular cracks opened downward into the trenches (Prudic and Randall, 1979). Siphoning about $110 \mathrm{~L}$ of water into cracks over the north end of trench 4 in July 1978 produced similar results. When several other cracks were tested in this manner, however, water soon began to issue from nearby cracks at lower altitude at a rate comparable to the rate of input. It was therefore concluded that some cracks, but not all, fully penetrated the trench covers. The cracks presumably result both from compaction and settlement of the waste and also to some extent from desiccation of the cover material (reworked till) during extended dry periods, as explained in the following paragraphs.

\section{CRACKS CAUSED BY SETTLING OF WASTE}

The contents of the buried waste containers were not precompacted, nor were the stacked containers compacted by heavy machinery, as is usual with municipal landfills. Thus, as the containers decay, the waste could collapse considerably. The cardboard and wooden containers, which constitute 5 to 30 percent of the waste (table 3), would collapse years before the metal barrels; and the concrete casks may remain intact for centuries. The gradual collapse of individual containers and the settlement of cover material into unfilled spaces between containers (Prudic, 1980 , p. 20) would result in fracturing and eventual caving of the unsupported cover. The resulting cracks would probably propagate upward from the bottom of the cover. Subcircular depressions and holes about $1 \mathrm{~m}$ in diameter, some surrounded by concentric cracks, were observed occasionally in the covers, mostly on top of trenches 3 through 5 and most frequently after spring thaw. These features, probably caused by collapse, were filled with additional cover by the site operator as soon as practical.

Subsidence fractures could also propagate downward from the surface along the edges of a trench either by shear force (if the cover settled uniformly with time) or by rotation (if the crown of the cover settled more rapidly 
than the sides). Longitudinal cracks have been noted along the edges of individual trenches. The lack of noticeable displacement of land surface along these longitudinal cracks suggests that uniform settlement was not significant but does not rule out rotational settling.

The sharp rise in water levels in trenches 11 and 14 in the fall of 1978, the year after water was pumped from them by Nuclear Fuel Services, gave rise to speculation that the removal of water indirectly caused cracks in the covers and allowed for rapid infiltration of precipitation into the trenches. The removal of water from the trenches produces a loss of buoyancy in the trenches and subsequently may cause the waste containers to collapse, the result of which is a loss of support to the cover and the formation of settlement cracks. This possibility, although it cannot be totally ruled out, was thought not to be the predominant cause of the accelerated waterlevel rises observed in trenches 11 and 14 because

1. Water levels began to rise rapidly in trenches 11 through 14 at approximately the same time (fig. $23 B$ ), even though trench 12 was pumped a year earlier than trenches 11 and 14, and trench 13 was not pumped at all. This suggests some other mechanism caused the rapid rise of water levels.

2. The south trenches (including 11 and 14) were saturated with water only near the bottom of the trenches; thus, the removal of water from these trenches would cause collapse of containers in only a small part of the trenches. In contrast, trenches 3 through 5 were saturated through their entire thickness and parts of the covers for at least a year
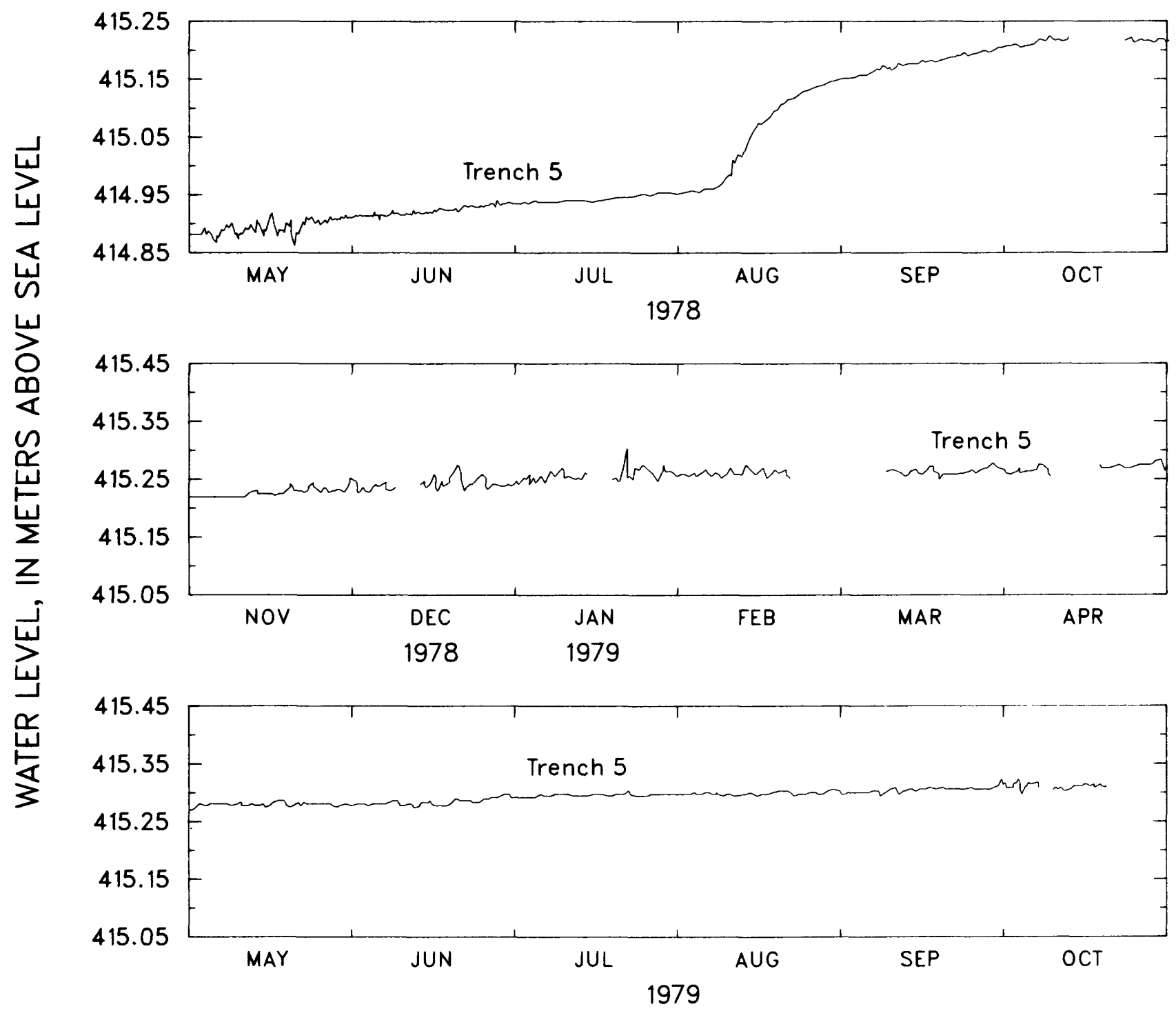

FIGURE 27.-Water level in trench 5 after covers of trenches 1 through 5 were regraded in August 1978. 
(see fig. 23A). If the removal of water caused the containers to collapse and fractures to form in the covers, then both the water-level rises and the number of subsidence holes in trenches 3 through 5 should have increased after 1976, which they did not, suggesting little increased collapse.

Thus, the removal of trench water does not seem to be the primary mechanism that caused the accelerated water-level rises in trenches 11 and 14 observed in the fall of 1978.

\section{CRACKS CAUSED BY SEASONAL DRYING OF COVER}

Shrinkage cracks caused by drying is a well-known phenomenon in fine-grained soils. Surface cracks were visible not only on the trench covers during summer but also in the till surrounding the trenches (Dana and others, 1978). Most of these cracks were absent during spring and are, therefore, assumed to be caused, or at least enlarged, by seasonal drying.

Numerous cracks were observed in the newly exposed unweathered till between Franks Creek and Buttermilk Creek east of the south trenches (fig. 2) in July 1979 after some of the till had been removed from the area and placed on the north trenches as cover during August 1978. Several cracks were between 2 and $5 \mathrm{~cm}$ in width, and a steel tape $(0.6 \mathrm{~cm}$ wide) was lowered $70 \mathrm{~cm}$ in a few places. Desiccation, or drying, of the till is the only plausible explanation of how these cracks formed. Exactly how deep the cracks penetrated the till is uncertain. Nearly vertical cracks extending to depths of 4.5 $\mathrm{m}$ and having oxidized rims were detected in the undisturbed till near the trenches (Prudic and Randall, 1979; Davis and Fakundiny, 1978, fig. II-5). However, it is not known whether drying during the most extreme droughts over the past 10,000 years caused the cracks to extend this deep or whether the cracks are caused by some other process. Nevertheless, shrinkage of the till during summer is a plausible explanation for at least the enlargement of cracks in the cover.

Comparison of changes in atmospheric pressure with changes in the gas pressure measured in trenches 4 and 12 in July 1977 and July 1978 indicate that the movement of air through the cover was much faster in July 1978 then in July 1977, particularly through the cover over trench 12 , where the estimated cover permeability was 50 times greater in July 1978 then in July 1977 (Prudic, 1980). This rapid movement of air through the cover of trench 12 in July 1978 was probably not caused by the movement of air through pores in the till matrix but rather through cracks that extended through the cover for the first time. If cracks had extended through the cover over trench 12 before the summer of 1978 , the change in permeability of the cover should have been similar to that of the trench 4 cover, which had increased by a factor of only 3 (Prudic, 1980). Also, if cracks had extended through the cover over trench 12 before the summer of 1978, the water level in the trench should not have remained stable but should have increased as in the fall of 1978 .

Shrinkage cracks are also a plausible explanation for the sudden onset of rapidly rising water levels in trenches 3 through 5 in late 1971 and in trenches 11 through 14 in late 1978 (Prudic, 1979b), each after an unusually dry summer. How deep the shrinkage cracks extend into the cover is uncertain. To admit water, however, shrinkage cracks need not penetrate through the cover but rather need only to intersect cracks propagating upward as a result of refuse decay or perhaps enlarge older cracks caused by the general settling of the cover. Although the mechanisms of crack development are not exactly known, it seems reasonable that shrinkage at least accelerated the development of cracks through the cover. Once these cracks extend through the cover, water can drain through, making the cracks less likely to swell shut or to become sealed with mud.

The relative dryness of the summers of 1971 and 1978 is evident from a variety of precipitation and runoff records. A rain gage was installed at the site in May 1975; comparison of 1975-79 data with records from four nearby long-term National Weather Service stations suggests that precipitation at Franklinville, $15 \mathrm{~km}$ southeast of West Valley, is the most nearly equivalent to that at the burial site. At Franklinville, the years having lowest annual precipitation since the earliest trenches were completed were 1971,1973 , and 1978 (National Weather Service, 1966-79). Perhaps more significant is minimum precipitation during the growing season. Precipitation during the 60 consecutive days of least precipitation in each growing season was relatively low in 1969 and 1971, and in 1978 was by far the lowest (table 11). Precipitation similarly compiled for 30-day periods was relatively low in five summers, including TABLE 11.-Lowest 30-day and 60-day cumulative rainfall periods from
May through October, 1968 through 1978 , at Franklinville, $N . Y$.

[Values are in centimeters]

\begin{tabular}{|c|c|c|c|c|}
\hline \multirow[b]{2}{*}{ Year } & \multicolumn{2}{|r|}{ 30-day interval } & \multicolumn{2}{|r|}{ 60-day interval } \\
\hline & Value & Dates & Value & Dates \\
\hline 1968 & 3.91 & July 1-July 30 & 14.86 & June 29-Aug. 27 \\
\hline 1969 & 4.04 & Aug. 4-Sept. 2 & 9.14 & Aug. 4-Oet. 2 \\
\hline 1970 & 3.18 & July 22-Aug. 20 & 12.62 & June 23-Aug. 21 \\
\hline 1971 & 3.63 & May $1-$ May 30 & 8.99 & June 16-Aug. 14 \\
\hline 1972 & 5.31 & Aug. 15-Sept. 13 & 12.14 & July 16 -Sept. 13 \\
\hline 1973 & 5.31 & June 29 -July 28 & 10.87 & Aug. 3-Oct. 1 \\
\hline 1974 & 4.88 & June 30 -July 29 & 15.09 & May 19-July 14 \\
\hline 1975 & 3.56 & June 21-July 20 & 11.30 & June 21-Aug. 19 \\
\hline 1976 & 2.54 & Aug. 9-Sept. 7 & 15.75 & Aug. 9-Oct. 7 \\
\hline 1977 & 4.83 & May 7-June 5 & 14.96 & May 6-July 4 \\
\hline 1978 & 1.78 & June 23 -July 22 & 5.92 & May 23-July 21 \\
\hline
\end{tabular}


1971 and 1978; however, development of deep shrinkage cracks may require dry periods of more than 30 days. Average precipitation during the growing period (May through October) at the four National Weather Service stations was relatively low in 1971,1974 , and 1978, with 1971 by far the lowest; the same is true of lowest mean flow of Cattaraugus Creek at Gowanda for 30- or 60-day periods (table 12). (Low flow reflects the combined effects of rainfall, evapotranspiration, and storage over a large area.) Thus it can be concluded that water levels in trenches 3 through 5 began to rise rapidly after the first unusually dry summer (1971) following the regrading of the trenches in 1969 (see table 2). Similarly, water levels in trenches 11 through 14 began to rise rapidly after their first unusually dry summer (1978), following the regrading of the trenches from 1973 to 1975 (table 2). This pattern strongly supports the hypothesis that cracks in the trench cover, caused partly by shrinkage and partly by collapse, are the most important avenues of recharge.

TABLE 12.-Low flow of Cattaraugus Creek at Gowanda Station $04-213500$

[Values are in cubic meters per second]

\begin{tabular}{|c|c|c|c|c|c|}
\hline \multirow[b]{2}{*}{ Year } & \multicolumn{2}{|c|}{$\begin{array}{c}\text { Lowest average } \\
\text { consecutive-day flow }\end{array}$} & \multirow[b]{2}{*}{ Year } & \multicolumn{2}{|c|}{$\begin{array}{c}\text { Lowest average } \\
\text { consecutive-day flow }\end{array}$} \\
\hline & 30 days & 60 days & & 30 days & 60 days \\
\hline 1963 & 2.32 & 2.78 & 1971 & 2.92 & 3.20 \\
\hline 1964 & 2.66 & 2.95 & 1972 & 5.21 & 6.51 \\
\hline 1965 & 2.27 & 2.66 & 1973 & 4.30 & 4.67 \\
\hline 1966 & 3.48 & 3.77 & 1974 & 3.79 & 3.96 \\
\hline 1967 & 4.90 & 5.35 & 1975 & 5.41 & 6.66 \\
\hline 1968 & 3.26 & 3.77 & 1976 & 4.98 & 7.79 \\
\hline 1969 & 4.39 & 4.90 & 1977 & 7.08 & 9.06 \\
\hline 1970 & 6.43 & 8.30 & 1978 & 3.88 & 4.13 \\
\hline
\end{tabular}

\section{CHEMISTRY OF TRENCH WATER}

As explained previously, water has accumulated in the burial trenches since their beginning, saturating at least the lower part of the buried waste and slowly percolating outward and downward from the trenches into the till. The advection and dispersion of dissolved constituents within the water probably are the principal methods of subsurface transport of radionuclides. Because of the abundant decaying organic matter and the variety of wastes, solvents, and cleaning agents buried in the trenches, the chemical environment within the trenches is complex and has potential for a variety of chemical and biological processes that may influence the solubility or sorption of individual radionuclides.

This investigation did not include detailed study of trench-water chemistry. Interpretations of radionuclide migration are based largely on the distribution of radionuclides in cores collected from alongside and beneath the trenches and comparison with the radionuclide con- tent of trench water as reported by others. Concurrent investigations by Brookhaven National Laboratory (Weiss and Colombo, 1980) and the Radiological Sciences Laboratory of the New York State Department of Health (Husain and others, 1979) have included sophisticated sampling of trench water and detailed organic, inorganic, and radiochemical analyses of samples to provide data that may lead ultimately to a better understanding of the processes involved in radionuclide transport.

\section{SAMPLING METHODS}

While each trench was being filled with waste, water that accumulated on the downward sloping trench floor in front of the waste was periodically pumped out and analyzed for tritium, gross beta, and gross alpha (table 13). Initially the trench water was pumped into the nearby streams, but by the time trench 8 was completed, and perhaps sooner, the water was pumped into a lagoon, then to the wastewater-treatment plant to have most of the radionuclides removed (except tritium) before being discharged into a tributary to Franks Creek. The trench water was derived from precipitation on the exposed waste and on the $15 \mathrm{~m}$ or so of open trench ahead of the waste, plus any water draining from waste in previously covered segments of the trench. Trench-water samples in 1973 were collected by lowering a glass bottle into the trench standpipes (Matuszek and others, 1976) and were analyzed for several radionuclides (Duckworth and others, 1974). These early samples may have underrepresented the radionuclide concentration of trench water (see table 13) because both the standpipes and the trenches were open to the atmosphere and to rain.

The Radiological Sciences Laboratory of the New York State Department of Health and Brookhaven National Laboratory collected several samples of trench water for analysis during 1976-79. Samples in 1976-77 were collected with flexible polyvinyl chloride tubing and a peristaltic pump (Davis and Fakundiny, 1978; Dana and others, 1978; Husain and others, 1979; Colombo and Weiss, 1979). The tubing was lowered nearly to the bottom of the well or standpipe. After 20 to 60 liters of water had been pumped into a container to remove most of the water that was in or near the standpipe or well, 1- to 2-L samples were collected in a polyethylene or glass jar. All samples were exposed to air and within minutes changed from green-gray to orange-red (Colombo and Weiss, 1979). Beginning in November 1977 , 4- to 20 -L samples were collected by a technique that did not expose them to air (Colombo and Weiss, 1979). The new technique included in-line measurements of $\mathrm{pH}, \mathrm{Eh}$, and temperature, and in 1978, dissolved oxygen and specific conductance were also 
measured. The samples were taken only after the measurements had stabilized to ensure that most or all of the water being pumped was from the trench and not from the well or standpipe. Gross alpha and gross beta determinations, as well as the concentration of tritium, increased from the time when water was first sampled in the trenches (table 13) to the sample collection during 1975-78 (table 13). However, the earlier samples may not accurately represent the composition of the trench water because of the method of collection.

\section{COMPOSITION OF TRENCH WATER}

Representative chemical and radiochemical analyses of water from several trenches are shown in tables 14 and 15 . The concentrations of nonradioactive chemical species are within the range found in water from wells screened at or just below the base of refuse in municipal landfills in Illinois (Hughes and others, 1971) and Indiana (Pettijohn, 1977). Chemical concentrations in leachate from municipal refuse recovered at or above the water table and analyzed in the field and laboratory commonly exceed the largest values of many constituents in table 14 (Apgar and Langmuir, 1971; Ehlke, 1979, A. D. Randall, U.S. Geological Survey, written commun., 1973; and Qasim and Burchinal, 1970). Most concentrations listed in table 14 are equal to or greater than those in water from the radioactive-waste burial trenches at Maxey Flats, Ky. (Colombo and others, 1978a, b), and Sheffield, Ill. (Weiss and Colombo, 1980). The sodium and potassium concentrations in table 14 exceed those in most samples from landfills described in these references. Although no attempt was made to determine the migration rate of trench water from the migration rate of a stable isotope such as chloride, this procedure should be possible because of the large concentration differences of certain dissolved substances between the trench water and native water from the till. (Compare tables 1 and 14.)

Tritium was the most common radionuclide in all trenches, followed by ${ }^{90} \mathrm{Sr}$ and ${ }^{14} \mathrm{C}$. Concentrations listed in table 15 are similar to those in trench water from Maxey Flats, Ky. (Weiss and Colombo, 1980). The concentrations of radioactive species were roughly the same in all trenches from which samples were collected, except that ${ }^{90} \mathrm{Sr}$ in trench 4 was at least 10 times higher than in the other trenches, and ${ }^{238} \mathrm{Pu}$ in trenches 8 and 10 was about 1,000 times higher than in the others.

\section{RADIONUCLIDE MIGRATION FROM TRENCHES}

Nearly 400 segments of cores from test holes drilled near, between, and beneath the trenches as part of this study were submitted to the Radiological Sciences Laboratory of the New York State Department of Health for radiochemical analysis. Each was analyzed for tritium; some with elevated tritium content were analyzed for other radionuclides. The analytical technique is described by Matuszek and others (1976) and Dana and others (1980). In general, the water was vacuum distilled from each sample and analyzed for tritium; the remaining dry sample was analyzed for other radionulcides. Therefore, tritium concentrations are reported in $\mu \mathrm{Ci} / \mathrm{mL}$, whereas other radionulcides are reported in $\mu \mathrm{Ci} / \mathrm{g}$ and represent the total concentration in the water and soil.

Matuszek and others (1976) analyzed cores from 17 test holes augered in 1973-74 around the perimeter of the trenches and noted that tritium peaked at depths between 1 and $3 \mathrm{~m}$ and that other radionuclides peaked closer to land surface. The cores were obtained by a $5-\mathrm{cm}$ split-spoon sampler lowered to the bottom of the hole through hollow-stem augers. They concluded that although lateral migration from the trenches is a possible explanation for these shallow peaks at some locations, the contamination at other locations was entirely above historic water levels in nearby trenches and that the best explanation would therefore be some combination of surface processes such as (1) spills during emplacement of refuse or during removal of excess water from trenches, (2) redistribution of contaminated water by excavation equipment that entered the trenches, or (3) fallout from the stack at the nearby fuel-reprocessing plant. Data from the present study support this conclusion; near the south trenches and also east of trench 2, peak values of tritium and the presence of other artificial radionuclides were found above the highest water levels recorded in adjacent trenches. In trenches 3 through 5, water levels have been high enough that lateral seepage cannot be ruled out as an explanation for peak tritium concentrations near land surface in nearby test holes, but such migration could have been entirely through the cover material rather than through undisturbed till.

In an attempt to find evidence of radionuclide migration along fractures, the chemically altered till bordering prominent oxidized fractures in five cores was trimmed from the unaltered matrix for separate radiochemical analysis. Values of gross alpha and gross beta in fracture trimmings and matrix were nearly identical, and most individual isotopes in the trimmings were below detection limits. Thus, the concept that fractures are a major pathway for radionuclide migration remains unsupported. (Details are provided by Prudic and Randall, 1979, p. 880.)

Although one or more piezometers were usually installed in each test hole drilled in 1975-79 as part of this study, few water samples were submitted for 
TABLE 13.-Changes in concentration of tritium and gross alpha and gross beta determinations in trenches 4, 5, and 8 with time

[Results are in microcuries per milliliter. Exponents expressed in scientific notation, e.g., $1.6 \mathrm{E}-06$ means $1.6 \times 10-6 ;-$ means values not determined]

\begin{tabular}{|c|c|c|c|c|}
\hline $\begin{array}{c}\text { Date of sample } \\
\text { collection }\end{array}$ & Gross alpha & Gross beta & Tritium & Source of data \\
\hline \multicolumn{5}{|c|}{ Trench 4} \\
\hline Dec. $1966 \ldots \ldots \ldots$ & - & - & $2.1 \mathrm{E}-03$ & $\begin{array}{l}\text { Nuclear Fuels Services, Inc., written } \\
\text { comm., 1980.1 }\end{array}$ \\
\hline June $1967 \ldots \ldots$ & $9.2 \mathrm{E}-07$ & $1.8 \mathrm{E}-06$ & - & Do. \\
\hline Nov. $1973 \ldots \ldots \ldots$ & $<1.0 \mathrm{E}-07$ & $4.1 \mathrm{E}-04$ & $1.4 \mathrm{E}-01$ & Duckworth and others, 1974. \\
\hline Oct. $1975 \ldots \ldots \ldots$ & $1.0 \mathrm{E}-06 \pm 40 \%$ & $9.8 \mathrm{E}-03 \pm 3 \%$ & $5.99 \mathrm{E}-01 \pm 3 \%$ & Davis and Fakundiny, 1978. \\
\hline June 1976 & $9 \mathrm{E}-07 \pm 67 \%$ & $1.5 \mathrm{E}-02 \pm 3 \%$ & $2.83 \mathrm{E}-01 \pm 3 \%$ & Do. \\
\hline Sept. $1976 \ldots \ldots \ldots$ & $8 \mathrm{E}-07 \pm 88 \%$ & $2.8 \mathrm{E}-02 \pm 3 \%$ & $3.83 \mathrm{E}-01 \pm 3 \%$ & Do. \\
\hline July $1977 \ldots \ldots \ldots$ & $<2.0 \mathrm{E}-07$ & $2.4 \mathrm{E}-02 \pm 1 \%$ & $4.5 \mathrm{E}-01 \pm 1 \%$ & Colombo and Weiss, 1979. \\
\hline Nov. $1977 \ldots \ldots$ & $6.3 \mathrm{E}-07 \pm 6 \%$ & $3.8 \mathrm{E}-02 \pm 1 \%$ & $3.0 \mathrm{E}-01 \pm 1 \%$ & Weiss and Colombo, 1980. \\
\hline Oct. $1978 \ldots \ldots$ & $1.4 \mathrm{E}-06 \pm 11 \%$ & $1.7 \mathrm{E}-02+1 \%$ & $3.0 \mathrm{E}-01 \pm 1 \%$ & Do. \\
\hline \multicolumn{5}{|c|}{ Trench 5} \\
\hline Jan. $1969 \ldots \ldots \ldots \ldots$ & $4.5 \mathrm{E}-07$ & $1.97 \mathrm{E}-06$ & $7.9 \mathrm{E}-02$ & $\begin{array}{l}\text { Nuclear Fuels Services, Inc., written } \\
\text { comm., 1980.1 }\end{array}$ \\
\hline Nov. $1973 \quad \ldots \ldots$ & $<2.0 \mathrm{E}-08$ & $2.7 \mathrm{E}-05$ & $3.1 \mathrm{E}-01$ & Duckworth and others, 1974. \\
\hline Mar. $1975 \ldots \ldots$ & - & - & $1.97 \pm 3 \%$ & Husain and others, 1979. \\
\hline Sept. $1975 \ldots$ & $1.1 \mathrm{E}-06 \pm 36 \%$ & $2.75 \mathrm{E}-04 \pm 3 \%$ & $2.20 \pm 2 \%$ & Davis and Fakundiny, 1978. \\
\hline Oct. $1975 \ldots$ & - & - & $1.73-2.06$ & $\begin{array}{l}\text { Davis and Fakundiny, } 1978 \text {; and } 10 \\
\text { samples collected during trench } \\
\text { pumpout. }\end{array}$ \\
\hline Oct. $1975 \ldots$ & $7.1 \mathrm{E}-05 \pm 4 \%$ & $6.6 \mathrm{E}-04 \pm 3 \%$ & $1.56 \pm 3 \%$ & Davis and Fakundiny, 1978. \\
\hline June 1976 & $1.3 \mathrm{E}-06 \pm 3 \%$ & $5.1 \mathrm{E}-04 \pm 3 \%$ & $1.82 \pm 3 \%$ & Do. \\
\hline Sept. $1976 \ldots \ldots \ldots$ & $1.5 \mathrm{E}-05 \pm 3 \%$ & $7.7 \mathrm{E}-04 \pm 3 \%$ & $1.73 \pm 3 \%$ & Do. \\
\hline July $1977 \ldots$ & $6.0 \mathrm{E}-06 \pm 18 \%$ & $6.5 \mathrm{E}-04 \pm 2 \%$ & $1.4 \pm 1 \%$ & Colombo and Weiss, 1979. \\
\hline Nov. $1977 \ldots$ & $4.9 \mathrm{E}-07 \pm 6 \%$ & $1.4 \mathrm{E}-03 \pm 1 \%$ & $9.5 \mathrm{E}-01 \pm 1 \%$ & Weiss and Colombo, 1980. \\
\hline Oct. $1978 \ldots$ & $8.9 \mathrm{E}-07 \pm 11 \%$ & $4.7 \mathrm{E}-04 \pm 1 \%$ & $2.3 \pm 1 \%$ & Do. \\
\hline \multicolumn{5}{|c|}{ Trench 8} \\
\hline Aug. $1970 \ldots \ldots \ldots$ & $2.05 \mathrm{E}-06$ & $4.85 \mathrm{E}-05$ & $1.25 \mathrm{E}-01$ & $\begin{array}{l}\text { Nuclear Fuels Services, Inc., written } \\
\text { comm., 1980.1 }\end{array}$ \\
\hline Nov. $1973-\ldots \ldots \ldots$ & $<4.0 \mathrm{E}-08$ & $4.7 \mathrm{E}-05$ & $7.1 \mathrm{E}-01$ & Duckworth and others, 1974. \\
\hline July $1977 \ldots \ldots$ & $6.3 \mathrm{E}-05 \pm 4 \%$ & $4.5 \mathrm{E}-04 \pm 1 \%$ & $4.01 \pm 1 \%$ & Colombo and Weiss, 1979. \\
\hline Nov. $1977 \ldots \ldots$ & $6.9 \mathrm{E}-05 \pm 2 \%$ & $4.2 \mathrm{E}-04 \pm 1 \%$ & $2.9 \pm 1 \%$ & Weiss and Colombo, 1980. \\
\hline Oct. $1978 \ldots \ldots \ldots \ldots$ & $1.3 \mathrm{E}-04 \pm 2 \%$ & $4.7 \bar{E}-04 \pm 1 \%$ & $3.7 \pm 1 \%$ & Do. \\
\hline
\end{tabular}

1 Based on analyses of water pumped from the open trenches into a lagoon.

TABLE 14.-Chemical quality of water in trenches 1

[Concentrations in milligrams per liter except for $\mathrm{pH}$, temperature, and specific conductance. Trench locations are shown in fig. 7]

\begin{tabular}{|c|c|c|c|c|c|c|}
\hline \multirow[b]{2}{*}{ Constituent/property } & \multicolumn{6}{|c|}{ Trench number } \\
\hline & 2 & 3 & 4 & 5 & 8 & 9 \\
\hline 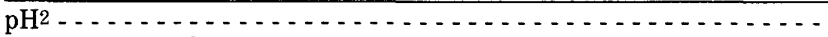 & 7.7 & 7.3 & 6.5 & 6.7 & 6.9 & 6.7 \\
\hline Temperature $\left({ }^{\circ} \mathrm{C}\right)^{2} \quad \ldots \ldots \ldots$ & 11.7 & 10.5 & 13.5 & 10.5 & 12.5 & 13.5 \\
\hline Specific conductance $2\left(\mu \mathrm{S} / \mathrm{cm}\right.$ at $\left.25^{\circ} \mathrm{C}\right) \ldots \ldots \ldots$ & 6,700 & 7,600 & 14,200 & 6,750 & 5,900 & 3,400 \\
\hline Barium $\ldots \ldots \ldots \ldots \ldots$ & $<1$ & 70 & 2,900 & 100 & 570 & $<1$ \\
\hline 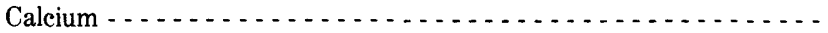 & 72 & 150 & 250 & 300 & 200 & 130 \\
\hline Cesium & $<0.1$ & $<0.1$ & $<0.1$ & $<0.1$ & $<0.1$ & $<0.1$ \\
\hline 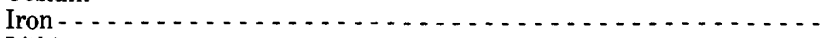 & 13 & 56 & 150 & 540 & 130 & 57 \\
\hline Lithium $\ldots \ldots$ & 0.87 & 2.0 & 0.39 & 0.98 & 0.16 & 1.3 \\
\hline 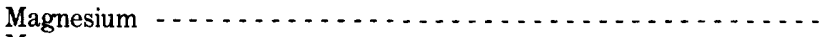 & 220 & 180 & 190 & 200 & 240 & 150 \\
\hline 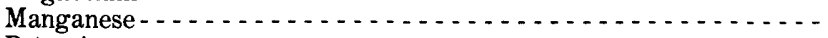 & $<0.1$ & 0.3 & 1.5 & 2.3 & 0.5 & 0.2 \\
\hline Potassium $\ldots \ldots \ldots \ldots \ldots \ldots$ & 330 & 320 & 820 & 270 & 300 & 91 \\
\hline Sodium $\ldots \ldots \ldots$ & 900 & 1,000 & 1,100 & 690 & 1,700 & 430 \\
\hline Strontium & 0.9 & 0.2 & 7.7 & 0.5 & 1.6 & 0.5 \\
\hline 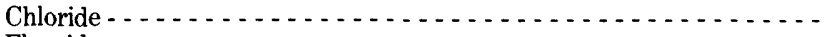 & 470 & 1,300 & 2,100 & 820 & 870 & 82 \\
\hline Fluoride $-\ldots \ldots \ldots \ldots \ldots$ & 4.1 & 1.8 & 0.4 & 2.0 & 0.6 & 1.8 \\
\hline \multicolumn{7}{|l|}{ Nitrogen } \\
\hline 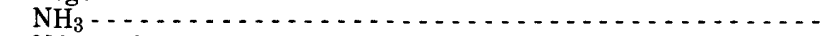 & 230 & 300 & 130 & 180 & 290 & 84 \\
\hline 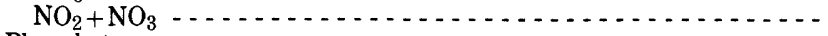 & $<0.05$ & 1.6 & 0.87 & 1.1 & $<0.02$ & $<0.02$ \\
\hline Phosphate & $<1$ & 2.9 & 8.0 & 3.4 & 5.8 & 12 \\
\hline Silica $-\ldots, \ldots \ldots \ldots$ & 15 & 2.0 & 13 & 9.2 & 10 & 14 \\
\hline Sulfate & $<5$ & 26 & $<5$ & $<5$ & $<5$ & $<5$ \\
\hline Inorganic carbon $\ldots \ldots \ldots \ldots$ & 670 & 95 & 130 & 10 & 70 & 120 \\
\hline Dissolved organic carbon & 200 & 1,700 & 630 & 2,900 & 2,900 & 1,700 \\
\hline \multicolumn{7}{|l|}{ Hardness as $\mathrm{CaCO}_{3}$} \\
\hline Calcium-magnesium $\ldots \ldots \ldots \ldots \ldots$ & 1,100 & 1,100 & 1,500 & 1,700 & 1,400 & 930 \\
\hline Alkalinity as $\mathrm{CaCO}_{3} \ldots \ldots$ & 3,120 & 1,730 & 800 & 2,300 & 2,000 & 1,600 \\
\hline Dissolved solids $\ldots \ldots \ldots \ldots$ & 3,070 & 5,140 & 1,240 & 5,310 & 5,600 & 3,850 \\
\hline
\end{tabular}

1 Values from Weiss and Colombo (1980, p. 82-85)

2 Values determined in field. 


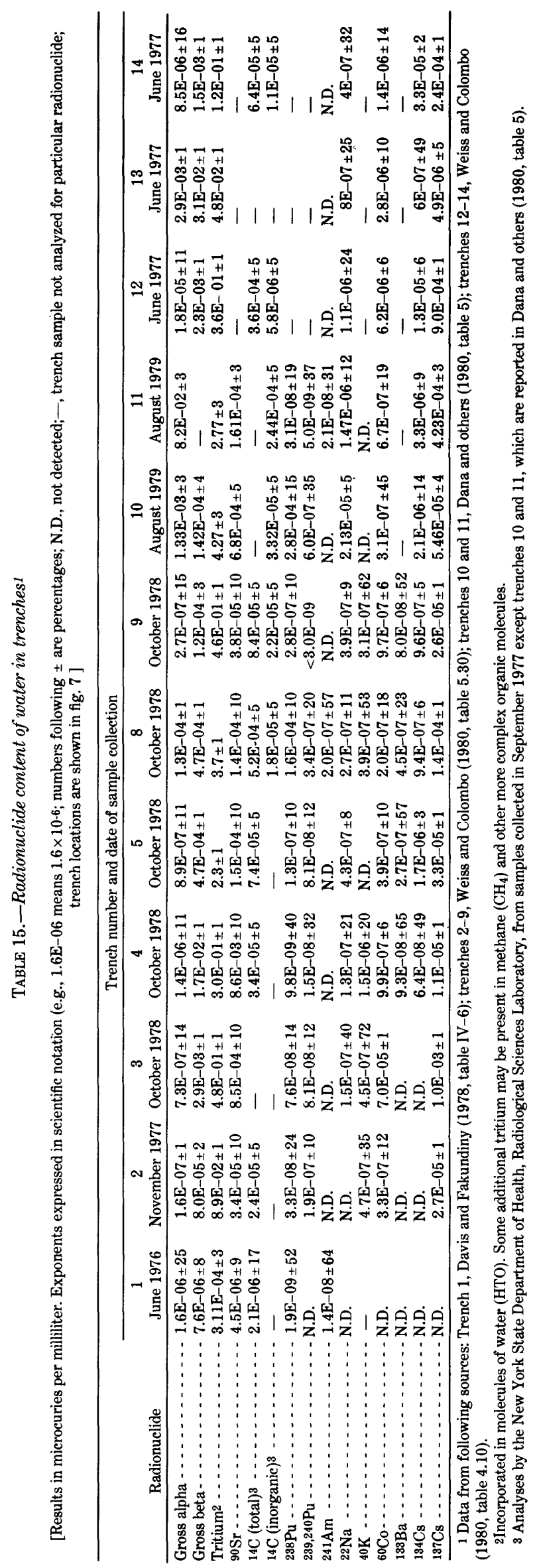


radiochemical analysis. The need for head measurements precluded frequent sampling because most piezometers required several weeks to return to static water level, even after withdrawal of only $300 \mathrm{~mL}$. Also, water in piezometers installed from 1975-78 was affected by the grout seal between piezometers, as indicated by $\mathrm{pH}$ values between 10 and 12 . Furthermore, the rates of flow through the till calculated in this study imply that about 10 years would be required for the flow system to flush from the piezometer the remaining water from which a sample had been withdrawn. Frequent sampling would distort the flow system and draw to the piezometer water that would not otherwise have reached it.

\section{OUTWARD MIGRATION}

In 1975, test holes were drilled at 16 locations near the burial ground, 12 of which were within $5 \mathrm{~m}$ of the trench boundaries (holes A-G, I-N, and P-R in fig. 7). Prudic and Randall (1979) described drilling and sampling techniques and presented profiles of tritium distribution with depth (fig. 28). Tritium concentrations were highest (generally $10^{-5}$ to $10^{-3} \mu \mathrm{Ci} / \mathrm{mL}$ ) near land surface, generally within the reworked till covering the trenches and vicinity and less commonly within weathered inplace till, but declined rapidly with depth in the zone of oxidized fractures. In the unweathered till below, concentrations were generally less than $1 \times 10^{-6}$ $\mu \mathrm{Ci} / \mathrm{mL}$. Analysis of a few cores for radionuclides other than tritium disclosed detectable quantities only at or near land surface, and gross-gamma and gammaspectral logging of several holes detected ${ }^{60} \mathrm{Co}$ and ${ }^{137} \mathrm{Cs}$ only in thin depth intervals within or at the base of the cover (Prudic and Randall, 1979, p. 881).

In three of the test holes drilled in 1975 (B, D, and $\mathrm{E}$, fig. 7), striking peaks in tritium concentration 10 to 100 times higher than samples immediately above or below the peaks (fig. 28 ) were detected in the till below the zone of oxidized fractures and at or below the estimated altitude of the nearby trench bottoms. These peaks were attributed to outward and downward migration of tritium from the trenches (Prudic and Randall, 1979), probably in part along lenses of silt whose permeability permitted more rapid flow and whose orientation may have favored lateral movement. The peaks in test holes D and E, just west of trench 5 (fig. 7 ), suggest that if the position of the trench wall were estimated correctly, tritium had migrated about $2.5 \mathrm{~m}$ in 6.5 years, and the peak in test hole B suggested a migration distance of at least $12 \mathrm{~m}$ in 11 years-much farther than any other documented subsurface migration and farther than would be predicted from average ground-water flow rates.

To verify whether the peak tritium concentration in test hole B (fig. 7) could be due to migration from near- by trenches rather than from surface contamination, two additional test holes were drilled by the U.S. Geological Survey between hole B and the end of trenches 2 and 3 in July 1978 (fig. 29). These holes were drilled and cores collected in a manner similar to that described by Prudic (1979a) for collecting cores beneath the trenches. The holes were backfilled with a bentonite-cement grout to a depth of $1 \mathrm{~m}$, and till cuttings were then packed into the hole to land surface. In both holes, gravel was encountered near the estimated altitude of the trench bottoms, and the tritium concentration was less than $6 \times 10^{-7} \mu \mathrm{Ci} / \mathrm{mL}$ in the entire section below the zone of oxidized fractures, including the gravel lenses, except in a single sample of till, in which the concentration was about $1 \times 10^{-6} \mu \mathrm{Ci} / \mathrm{mL}$ (fig. 29). Therefore, the hypothesis of downward and outward flow along a permeable lens from trench 2 or 3 seems inadequate to explain the high tritium concentration below the 409-m altitude at hole $\mathrm{B}$.

Two of the three samples from test hole $B$ that yielded anomalous tritium concentrations were among the few that could not be extracted from core liners in the field and were submitted to the laboratory without the usual trimming (Prudic and Randall, 1979, p. 868). A few meters west of hole B, a hole was augered by a contractor for Nuclear Fuel Services in 1973 from which cores were collected at $1.5 \mathrm{-m}$ intervals (hole 3 in fig. 7); all cores below an altitude of $414 \mathrm{~m}$ contained less than $6 \times 10^{-7} \mu \mathrm{Ci} / \mathrm{mL}$ tritium. The hole was allowed to collapse upon completion, and it is remotely possible that it became an avenue of vertical migration from contaminated soil near land surface.

A silty gravel about $1 \mathrm{~m}$ thick was penetrated in test hole $B$, and a sandy clayey silt and clayey silty gravel about $0.3 \mathrm{~m}$ thick was penetrated in test hole B3; both were about $1 \mathrm{~m}$ below pre-trench land surface and may perhaps continue northward beneath a nearby shallow depression (figs. 12A and 29). The similarity of the high tritium concentrations in the shallow gravel in test holes $B$ and B3 suggests that trench water may have migrated laterally along the unit from trench 3 to hole B when the water in trench 3 was above an altitude $416 \mathrm{~m}$. However, the unit seems to become thinner and finer grained toward trench 3 . Whether or not the unit actually intersects the wall of trench 3 is uncertain. Alternatively, the tritium peaks could have been caused by surface contamination that gradually migrated downward into the gravelly unit.

In summary, the drilling or augering of 29 test holes at distances of 2.5 to $5 \mathrm{~m}$ from the trenches in 1973-75 has disclosed only two sites where tritium has migrated laterally $2.5 \mathrm{~m}$ or more through the unweathered till. The lack of widespread lateral migration of tritium supports the conclusion that water leaving the trenches moves mostly downward. An outward lateral flow component next to the trenches occurs only when water 
A, North of north trenches.
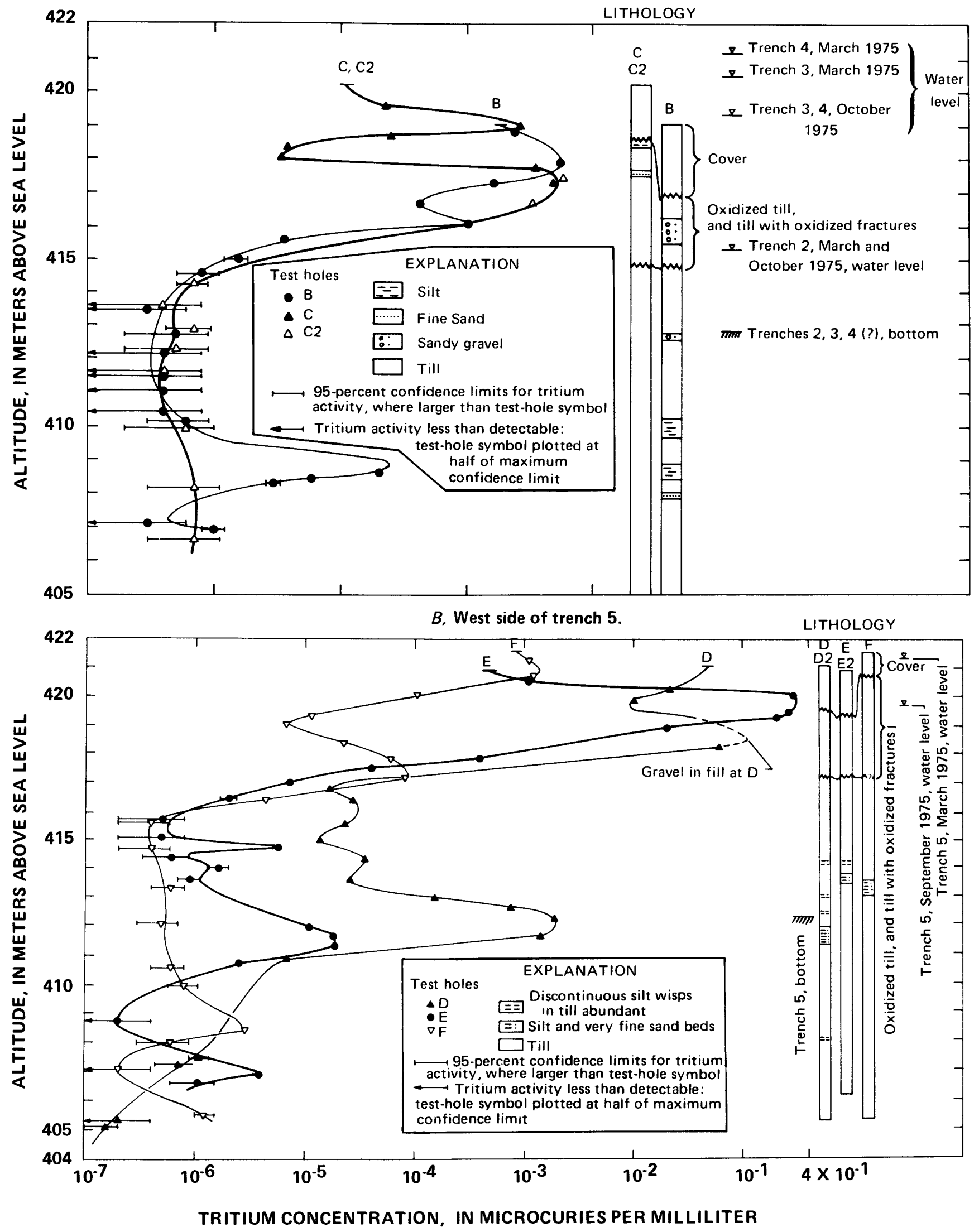

FIGURE 28.-Changes in tritium concentrations with depth in test holes near the burial site. Location of test holes is shown in figure 7 (from Prudic and Randall, 1979). A, North of north trenches. $B$, West side of trench 5. 
C, East side of trench 2.
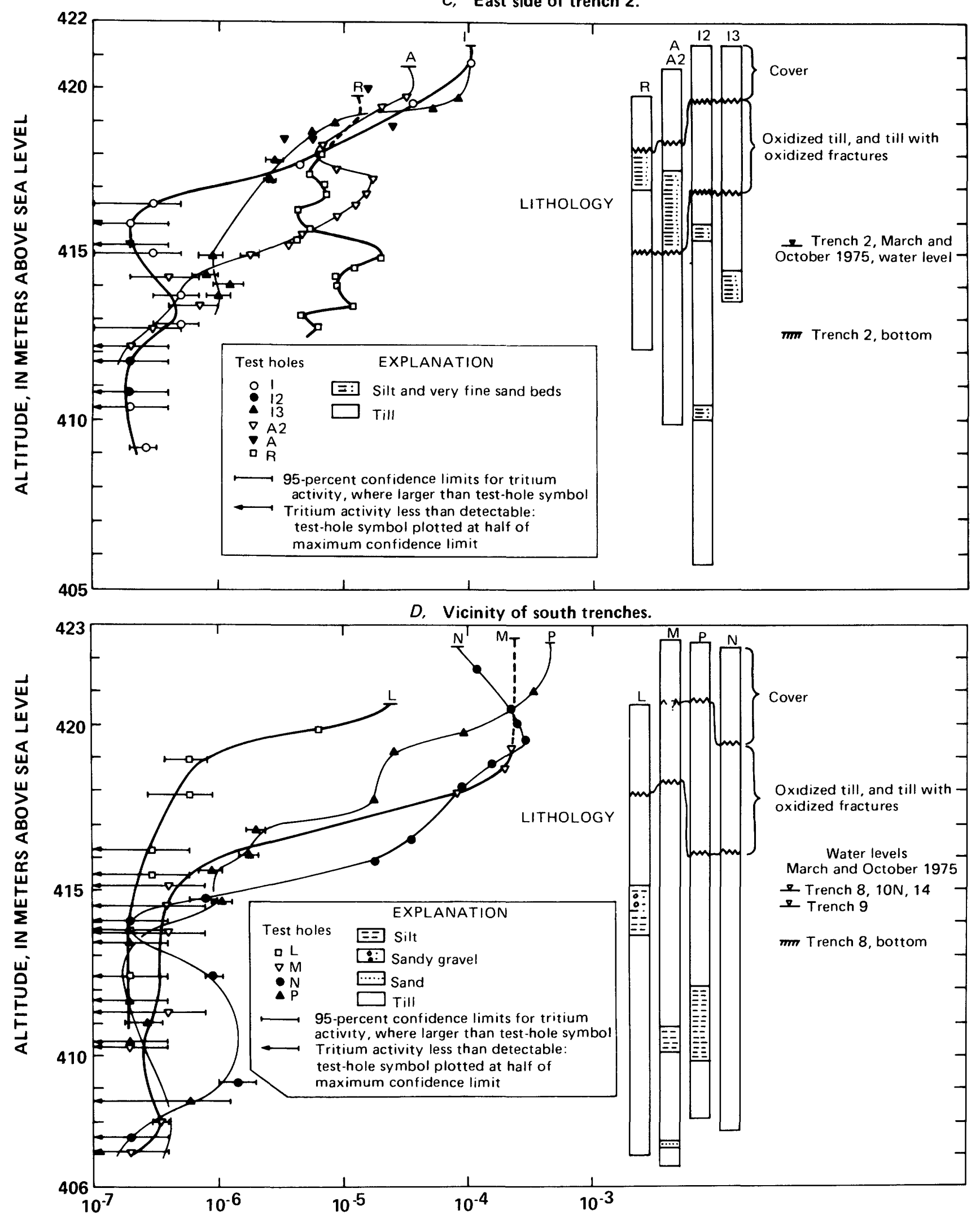

TRITIUM CONCENTRATION, IN MICROCURIES PER MILLILITER

FIGURE 28,-Continued.Changes in tritium concentrations with depth in test holes near the burial site. Location of test holes is shown in figure 7. $C$, East side of trench 2. D, Vicinity of south trenches. 


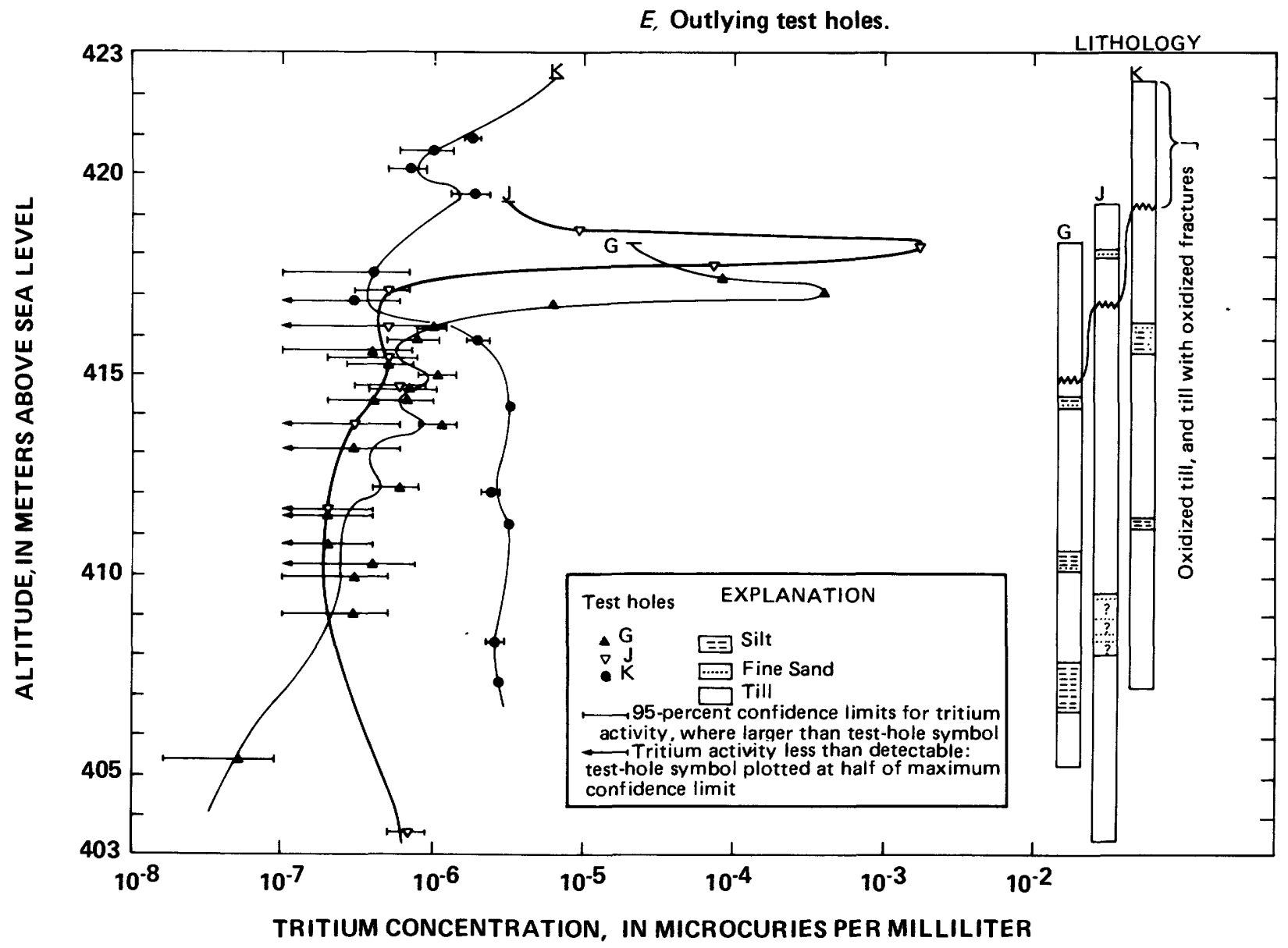

FIGURE 28. - Continued. Changes in tritium concentrations with depth in test holes near the burial site. Location of test holes is shown in figure 7. $E$, Outlying test holes.

levels in the trenches are high enough to intersect the more permeable weathered till or the reworked till used to cover the trenches.

\section{DOWNWARD MIGRATION}

In November and December 1977, several cores were collected beneath trenches 4,5 , and 8 from test holes driven through the trenches. The test holes were constructed by (1) driving a string of casing through the trench, (2) deciding when the casing had just penetrated the trench floor, (3) removing a retractable point from the end of the casing, and (4) collecting the first core with either a split-spoon or a solid tube sampler (Prudic, 1979a). A final estimate of the depth to bottom of the trench at sites 4-4 and 8-1 was prepared from a count of blows on the casing as it was driven through the trench, from geophysical logging inside the casing after it had been advanced well beyond the bottom, and from trench-construction records. The estimate of the depth to the bottom of the trench at site 8-1 was judged accurate only within $0.3 \mathrm{~m}$. The pipe at site $4-4$ seems to have penetrated either the side up the trench or collapsed waste two $\mathrm{m}$ above the projected trench floor from site 4-3. The uncertainty in the trench floor depth at site 4-4 cannot be estimated from the available data. At sites 5-2 and 8-2, auxilliary casings were driven and points removed above the trench floor so that a core could be collected starting just above the trench floor. At hole $5-2 \mathrm{E}$, the auxilliary casing was driven into backfilled or collapsed till above the trench floor, whereas at hole 8-2B, the point was opened while in the waste materials, as evidenced by the uppermost core sample, which included plastic, metal, and cardboard from above the unweathered till. A second core was collected below the trench floor in each auxilliary hole even though trench water was in the casing during the sampling. Estimates of the trench-floor depth were within $0.12 \mathrm{~m}$ at site $5-2$ and $0.07 \mathrm{~m}$ at site $8-2$. The result was to substantially reduce the error in the estimated depth of the trench floor.

A detailed description of the drilling and coring techniques as well as detailed geologic logs of each test hole are given in Prudic (1979a); complete results of radiochemical analyses are presented by Dana and others $(1979,1980)$. Naturally occurring radionuclides 


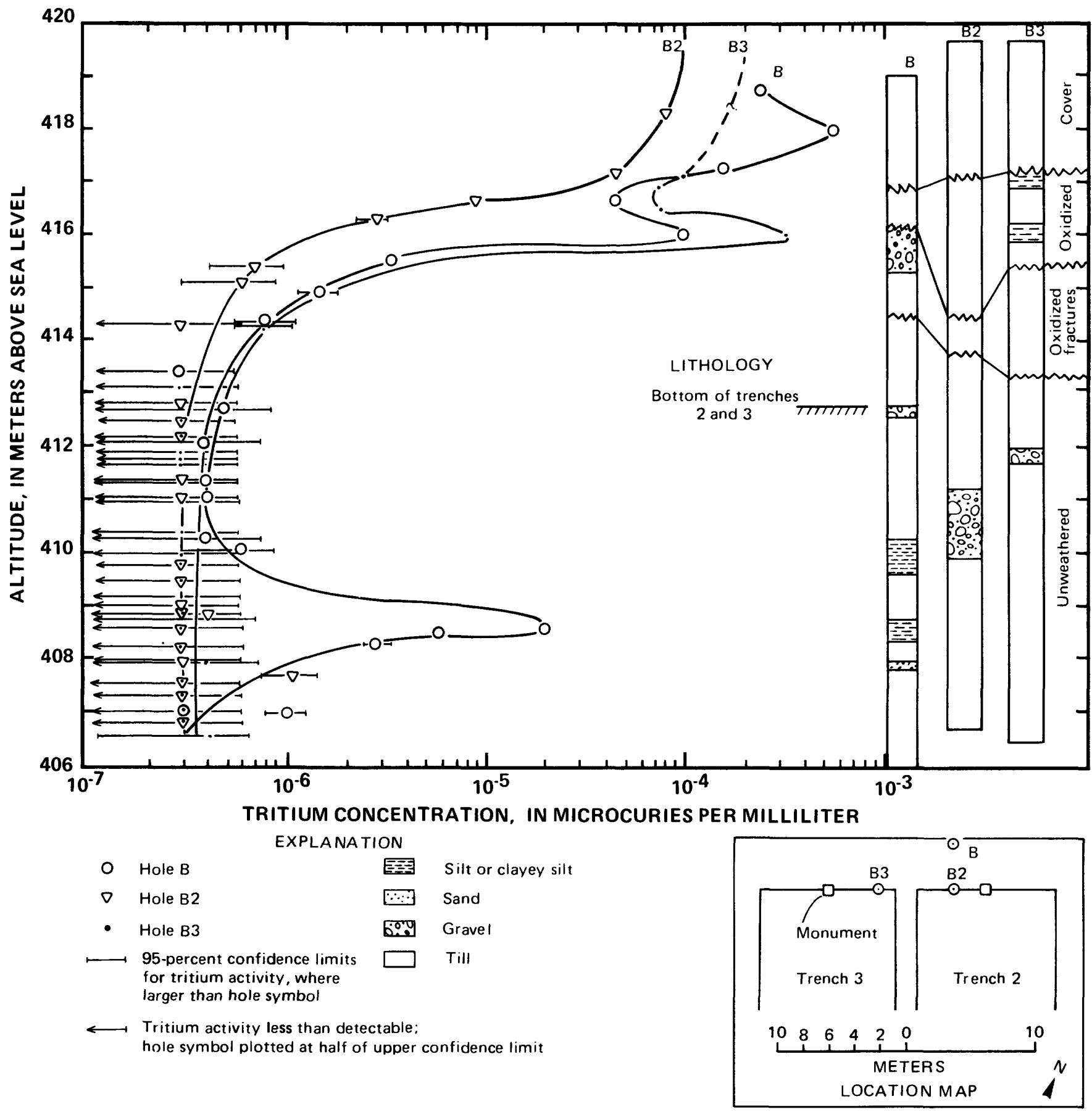

FIGURE 29.-Tritium concentrations in till at north end of trenches 2 and 3.

of uranium, potassium, and thorium were detected in all cores, but only a few other radionuclides that could be attributed to wastes in the trenches were detected below the upper part of the top core in each hole. Analyses for several radionuclides other than tritium are presented in table 16, including the weathered cardboard collected in hole 8-2B; tritium profiles are shown in figure 30 . Both are evaluated in the following paragraphs.
TRITIUM

Tritium was by far the most mobile radionuclide and was detected to a depth of $2 \mathrm{~m}$ beneath the estimated trench-floor altitude in till and to about $3 \mathrm{~m}$ in the silt underlying the south end of trench 8 (Prudic, 1979a). Distribution of tritium beneath the trenches is shown in figure 30 with a brief geologic $\log$ of each hole. 
66 RADIONUCLIDES AT A COMMERCIAL RADIOACTIVE-WASTE BURIAL SITE, CATTARAUGUS COUNTY, NEW YORK

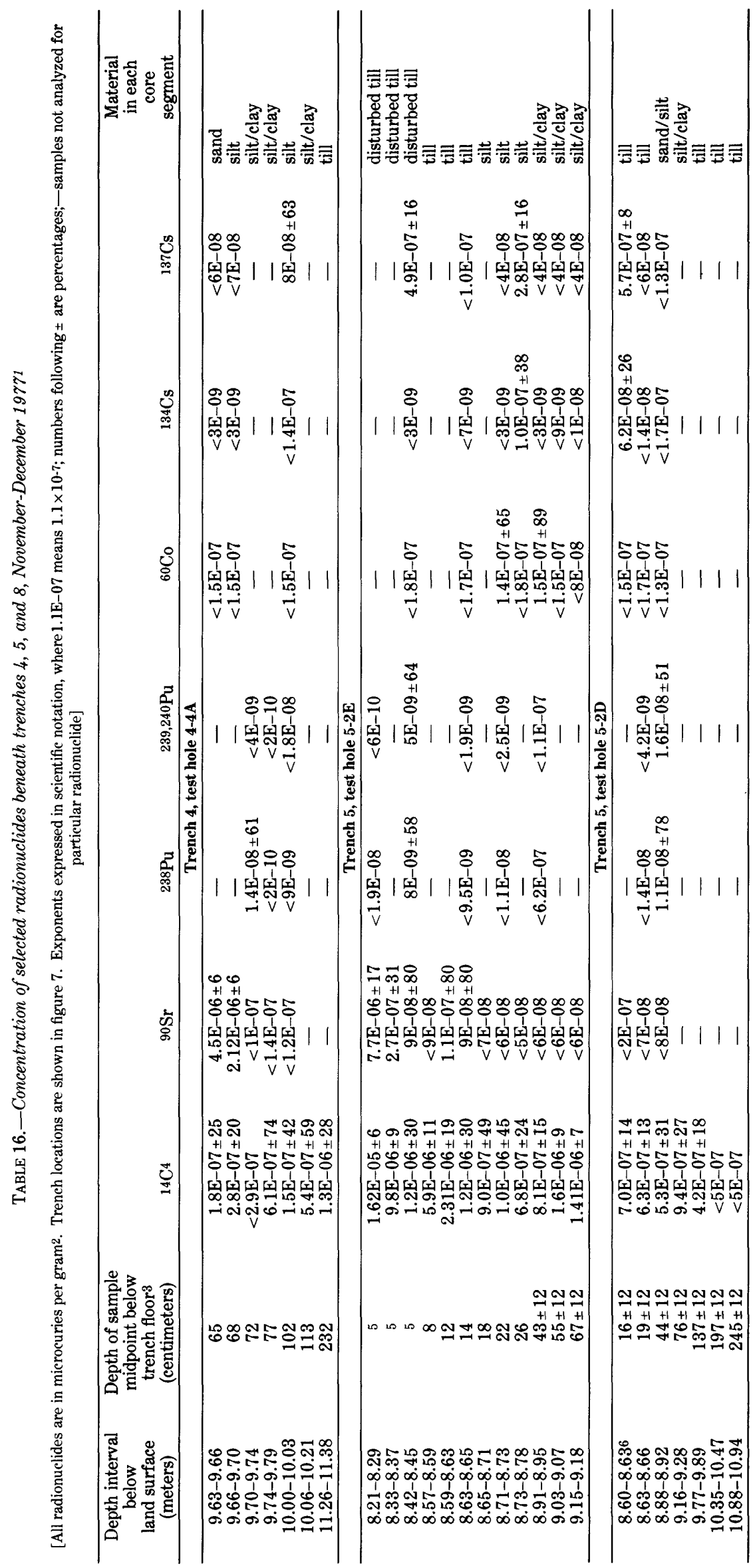




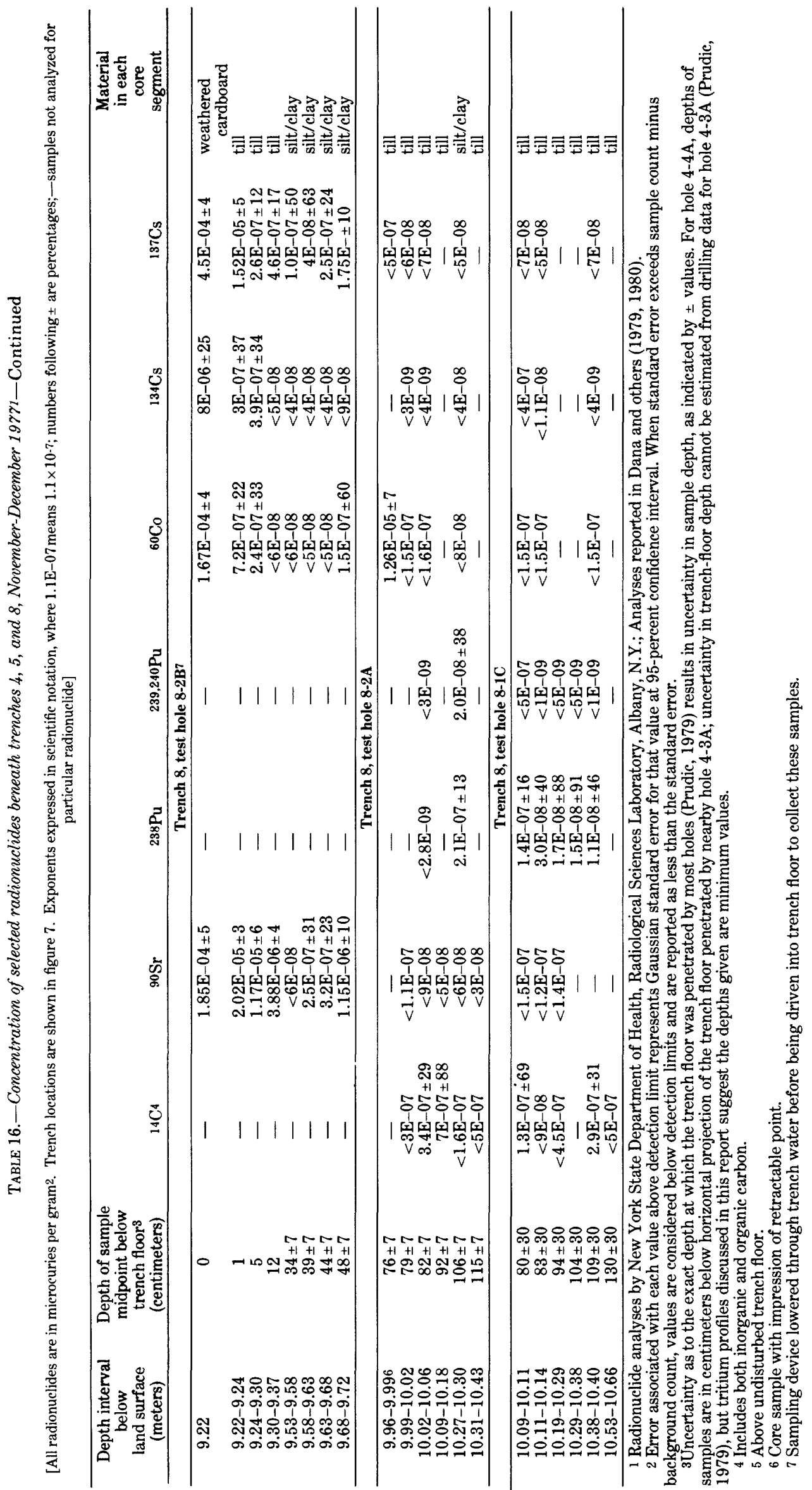




\section{COBALT AND CESIUM}

In general, concentrations of cobalt and cesium were below detection limits. Both were detected in the upper- most samples from most test holes, probably as a result of contact with the retractable point that had been driven through the refuse (Prudic, 1979a). Cesium was also detected in a few deeper cores at test hole 5-2E;

A, TRENCHES 4,5

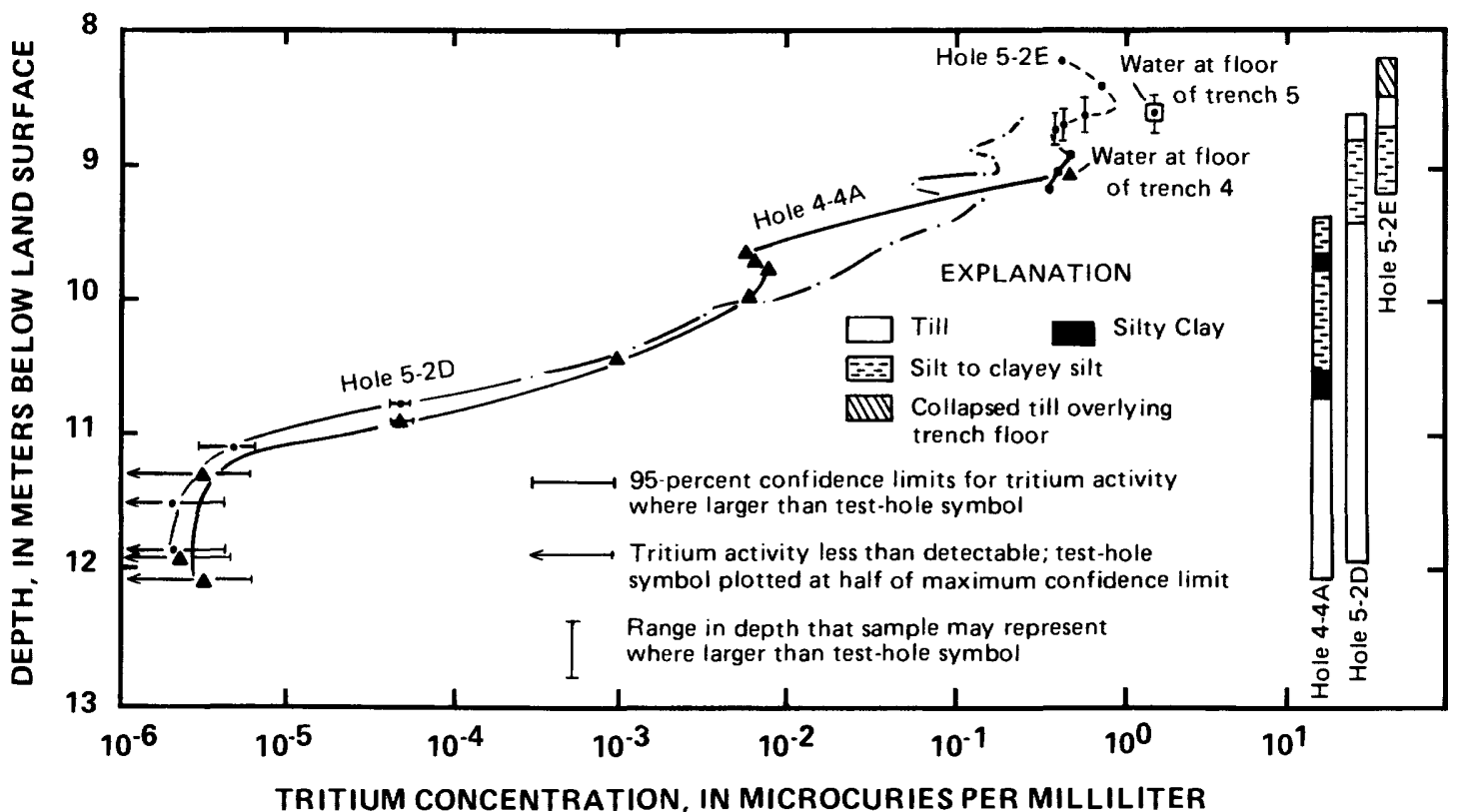

B, TRENCH 8

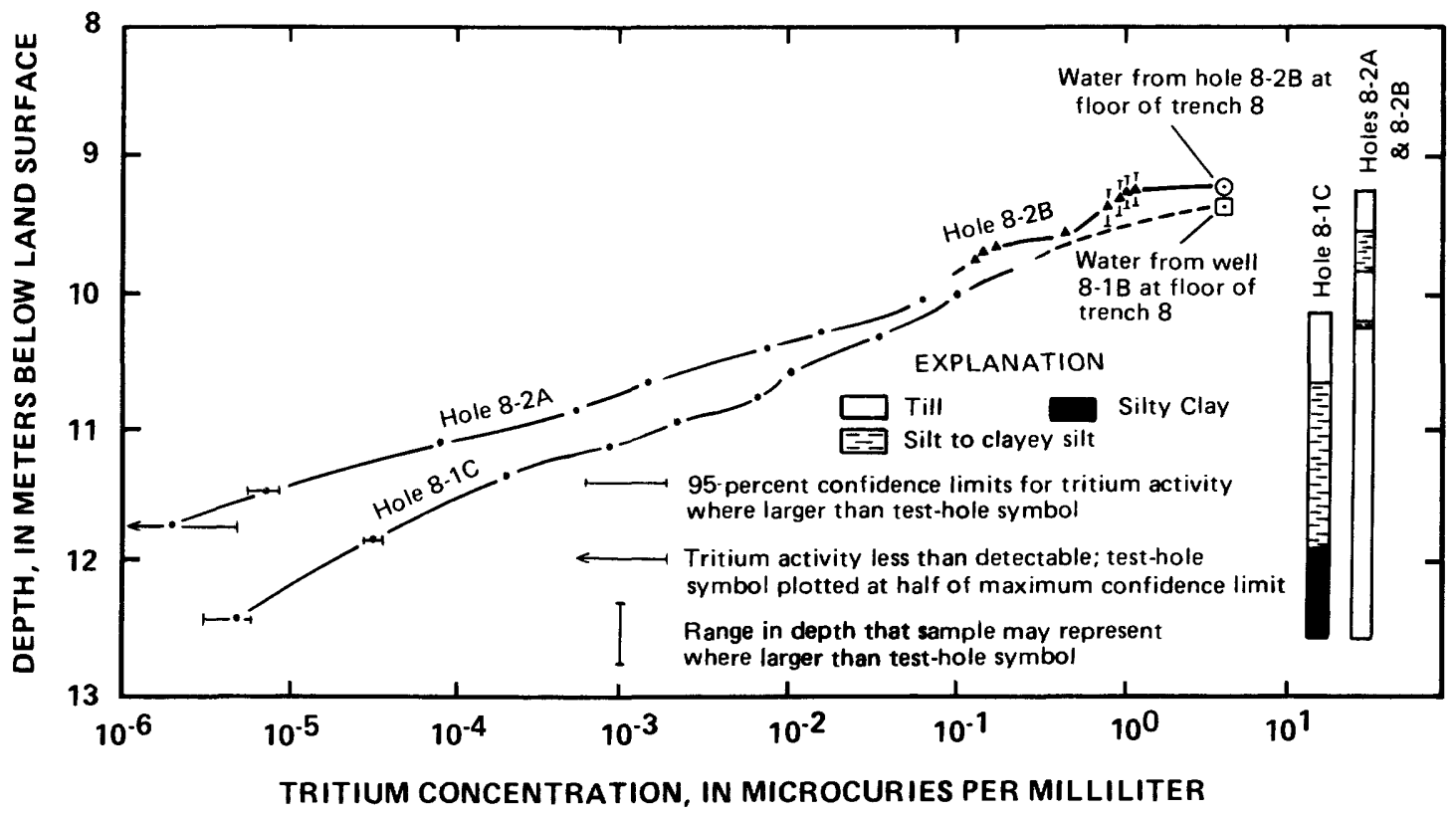

FIGURE 30.-Tritium concentration beneath selected trenches. $A$, Trenches 4 and 5 . Concentration in trench 4 is based on a sample from sump 4, $30 \mathrm{~m}$ south of test hole 4-4A (Davis and Fakundiny, 1978). Concentration in trench 5 is the average of samples from wells 5-2B and 5-2C (Husain and others, 1979), both within $1.5 \mathrm{~m}$ of hole 5-2D. B, Trench 8. Concentrations in trench 8 are based on samples collected from well 8-1B (Colombo and others, 1978a), about $1 \mathrm{~m}$ from test hole $8-1 \mathrm{C}$ and test hole 8-2B. 
these cores included backfill that had collapsed onto the trench floor, as well as disturbed lacustrine material within the till (unit 5 of table 4) beneath the trench floor. Migration of cesium through these lacustrine deposits seems plausible, particularly if the deposits intersect the trench floor (Prudic, 1979a).

Cobalt and cesium were also detected in test hole $8-2 \mathrm{~B}$, the purpose of which was to determine the exact depth of the trench floor. ${ }^{137} \mathrm{Cs}$ showed the deepest migration, about $48 \mathrm{~cm}$ (table 16). The second core in hole 8-2B penetrated disturbed beds of silt, clay, and fine sand, 33 to $50 \mathrm{~cm}$ below the trench floor, that contained more ${ }^{60} \mathrm{Co},{ }^{137} \mathrm{Cs}$, and ${ }^{90} \mathrm{Sr}$ than the overlying till. It is possible that the radionuclides migrated along these more permeable layers, particularly if the layers intersect the trench floor, but it seems more plausible that trench water in the casing was squeezed into these more permeable materials during sample collection. Contamination of the first core seems unlikely because the till is so fine-grained that water probably could not be squeezed into it. Both cores were recored and trimmed so that the samples analyzed were at least $6 \mathrm{~mm}$ less in diameter than the original core.

In test hole $8-2 \mathrm{~B},{ }^{134} \mathrm{Cs}$ was detected to only a depth of $5 \mathrm{~cm}$ below the trench floor, whereas ${ }^{137} \mathrm{Cs}$ was detected to a depth of $48 \mathrm{~cm}$, as noted above. The water in trench 8 contained about 1,000 times more ${ }^{137} \mathrm{Cs}$ than ${ }^{134} \mathrm{Cs}$ (table 15), which made the latter more difficult to detect in the limited samples available and probably explains the difference in possible migration distances of these two radionuclides.

\section{STRONTIUM}

${ }^{90} \mathrm{Sr}$ was detected beneath the trenches in only a few sections of core. ${ }^{90} \mathrm{Sr}$ was detected in the till about 14 $\mathrm{cm}$ beneath the floor of trench 5 , but in concentrations close to detection limits. In test hole $8-2 \mathrm{~B}$, at trench 8 , ${ }^{90} \mathrm{Sr}$ was detected to a depth of $12 \mathrm{~cm}$ in the till below the trench floor and also in the disturbed layers of silt, clay, and fine sand that occur between 33 and $50 \mathrm{~cm}$ below the trench floor. It is possible that the presence of ${ }^{90} \mathrm{Sr}$ in the disturbed layers of sediments is the result of migration along the more permeable layers. More likely, however, it is the result of contamination of these particular samples by trench water, because the test hole was opened above the trench floor.

The only other detectable ${ }^{90} \mathrm{Sr}$ concentrations were in the upper two samples from test hole 4-4A (table 16); these samples originated about $70 \mathrm{~cm}$ beneath the estimated trench-floor depth (Prudic, 1979a). However, test hole 4-4A seems to have either penetrated the side of trench 4 some distance above the floor or tapped uncontaminated refuse and (or) collapsed backfill (Prudic, 1979a, and fig. 31) because natural gamma logs of the hole indicate background radiation $2 \mathrm{~m}$ above the estimated trench floor. Furthermore, the ${ }^{90} \mathrm{Sr}$ in hole 4-4A cores was in an interval of distorted layers of silt and sand; concentrations in the till immediately below were less than detectable limits. The distribution of ${ }^{90} \mathrm{Sr}$ may, therefore, reflect any of the following.

1. Downward migration through about $2.6 \mathrm{~m}$ of undisturbed till below the sloping trench sidewall;

2. Downward migration through nearly $2 \mathrm{~m}$ of uncontaminated waste or collapsed backfill, then $0.7 \mathrm{~m}$ of undisturbed till, or

3. Downward migration along dipping silt and sand layers for $0.7 \mathrm{~m}$ and lateral migration for an unknown distance from the trench floor.

Deeper migration of ${ }^{90} \mathrm{Sr}$ beneath trench 4 than beneath trenches 5 or 8 seems reasonable because trench water in trench 4 contains 60 times more ${ }^{90} \mathrm{Sr}$ (table 15) and because trench 4 was completed 2 years before trench 5 and 3 years before 8 (table 2).

\section{CARBON}

Beneath trench $5,{ }^{14} \mathrm{C}$ was detected in several cores in concentrations considerably above detection limits (table 16), indicating that ${ }^{14} \mathrm{C}$ had migrated downward from that trench, perhaps as much as $1 \mathrm{~m}$ (see table 16, test hole 5-2D). However, the ${ }^{14} \mathrm{C}$ front could not be determined as precisely as that of tritium because (1) the cores were divided into small segments to better define the tritium front, but the small sample size increased the uncertainty in the measurement of ${ }^{14} \mathrm{C}$, and (2) the large but variable amounts of nonradioactive natural isotopes of carbon in these sediments resulted in dilution of ${ }^{14} \mathrm{C}$ and in difficulty in selecting the proper equipment size for analysis.

\section{PLUTONIUM}

Plutonium was near or below detection limits in most core segments from beneath the trenches. In general, finite values of ${ }^{238} \mathrm{Pu}$ and ${ }^{239,240} \mathrm{Pu}$ were limited to samples from within or immediately below the silt and sand layers, and from backfill material above the trench floor.

The uppermost sample in hole 8-1C, from a depth of about $80 \mathrm{~cm}$ beneath the estimated trench floor, contained ${ }^{238} \mathrm{Pu}$ in a concentration far above the detection limit; concentrations in deeper samples were all close to the detection limit. Relatively high concentrations of ${ }^{238} \mathrm{Pu}$ were also noted $106 \mathrm{~cm}$ below the floor of trench 8 at test hole 8-2A; this sample was from a thin lens of clay and silt, but the tritium profile for this hole (fig. $30 B$ ) did not suggest more rapid water movement along 
the silt lens. Most other radionuclides were below detection limits in all these samples. It is possible that ${ }^{238} \mathrm{Pu}$ might have migrated downward as much as $1 \mathrm{~m}$ below trench 8 , in which the water contains 3 to 4 orders of magnitude more ${ }^{238} \mathrm{Pu}$ than in most other trenches.

Evidence of plutonium migration has been reported from Oak Ridge, Tenn., where plutonium was detected in water seeping through soil from a radioactive-waste burial ground (Bondietti and others, 1975), and in Idaho, where soil cores contained plutonium 75 to $100 \mathrm{~cm}$ below solid radioactive waste buried in a pit (Humphrey and Tingey, 1978). However, the detectable concentrations of ${ }^{238} \mathrm{Pu}$ reported in table 16 could also be an artifact of the drilling or of counting statistics. Even though the

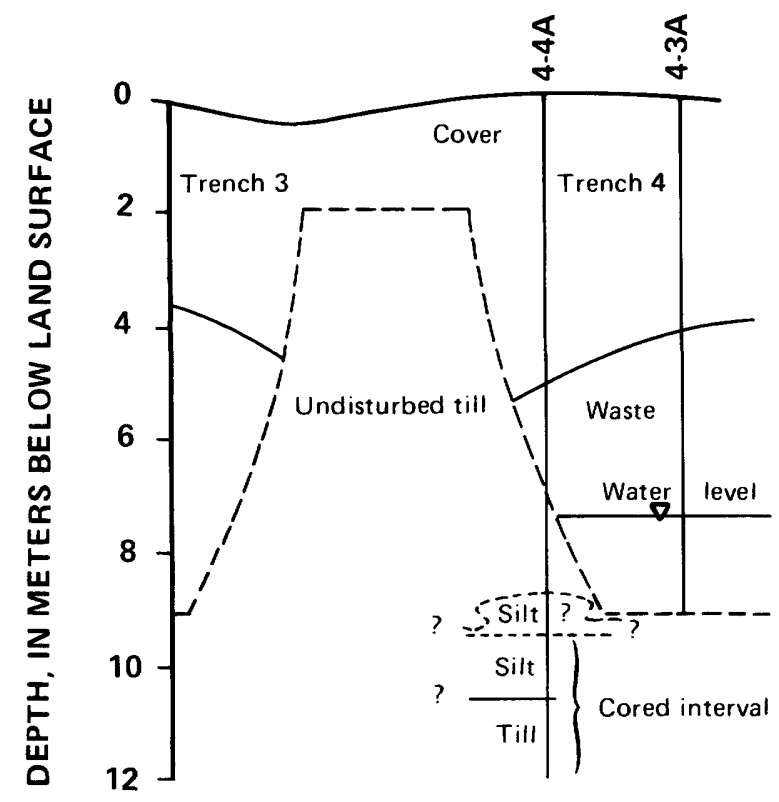

A. Drive pipe penetrates through trench wall

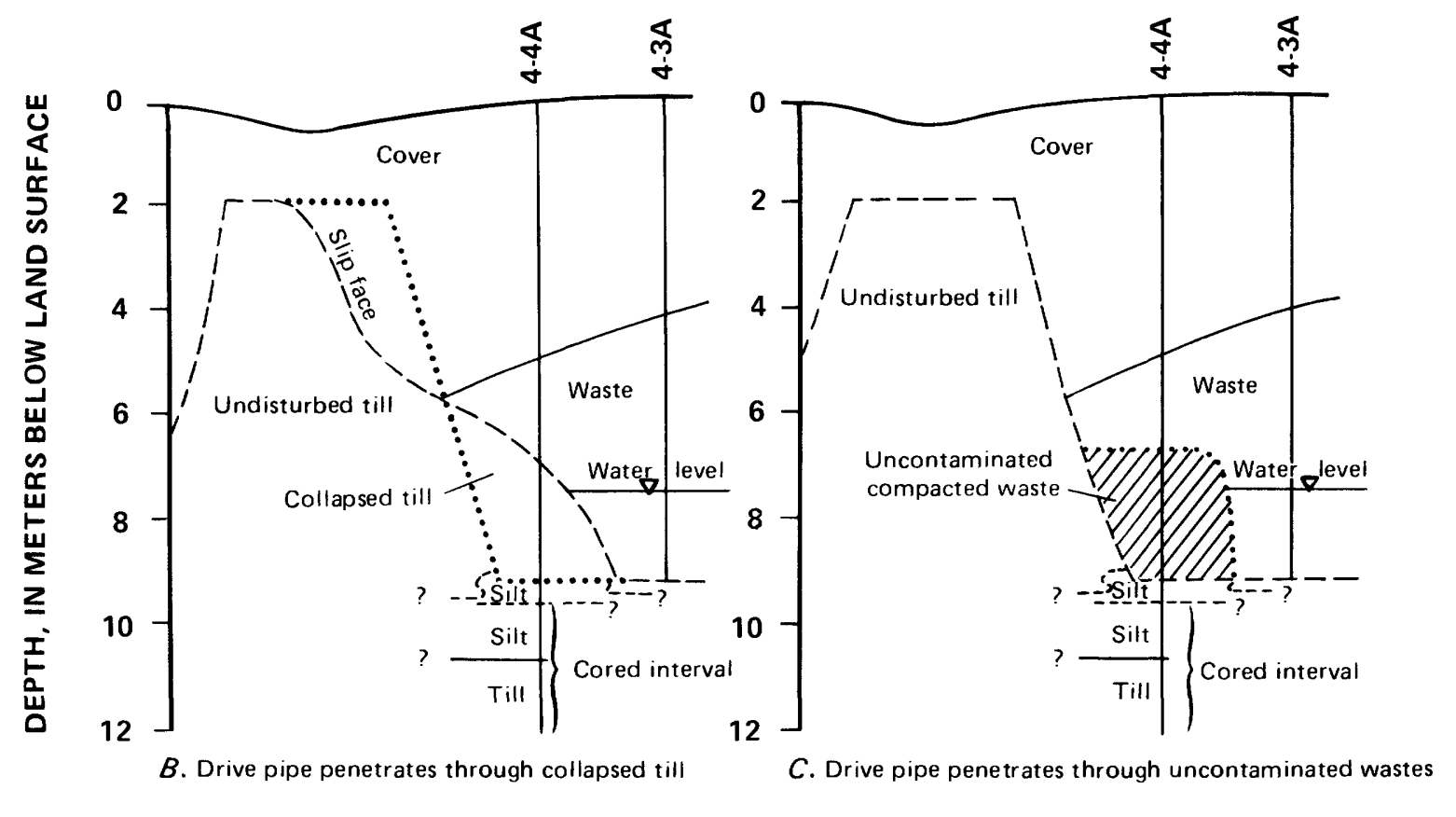

\begin{tabular}{lllllllll}
0 & 1 & 2 & 3 & 4 & 5 & 6 & METERS \\
\hline
\end{tabular}

FIGURE 31.-Inferred trench geometry near test holes 4-3A and 4-4A (from Prudic, 1979a, figure 17.) A, Drive pipe penetrates through sloping trench wall; trench wall is $1.5 \mathrm{~m}$ closer to hole $4-4 \mathrm{~A}$ than originally assumed. $B$, Drive pipe penetrates through collapsed till from trench wall. $C$, Drive pipe penetrates through uncontaminated wastes. Undisturbed till between trenches is assumed to be centered below topographic low, in accordance with engineering plans. 
upper few millimeters of the top core from hole 8-1C were trimmed away upon collection, the remaining sample might have been in contact with the retractable point before coring began and, if so, might easily have become contaminated by the point, which had been driven through the trench. Also, the 95-percent confidence level incorporated in the counting statistics used to measure radionuclide concentrations permits an occasional positive value, even though the concentration of the radionuclide is actually below detectable quantities.

In summary, migration of radionuclides away from the trenches is extremely slow. Tritium is the most mobile radionuclide and was detected to depths of $3 \mathrm{~m}$ beneath trenches 4,5 , and 8 in the 7 to 11 years after they were completed to fall 1977, when the samples were collected. The next most mobile radionuclide is ${ }^{14} \mathrm{C}$, which may have migrated as much as $1 \mathrm{~m}$ during the same period. Other radionuclides migrated less than 1 $\mathrm{m}$, and even that distance must be considered an overestimate if the sporadic appearance of the positive values (except for ${ }^{137} \mathrm{Cs}$ in hole $8-2 \mathrm{~B}$ ) is attributed to contamination during the sample collection, to accidents of counting statistics, or perhaps to migration through disturbed, discontinuous lenses of silt and sand.

\section{DISTRIBUTION COEFFICIENTS OF SELECTED RADIONUCLIDES}

The distribution coefficient describes the partitioning of adsorbed species between the solute and solid phases in the flow system. This partitioning causes the center of mass of a solute moving from a point source while undergoing adsorption to be lagged or retarded behind the mass of a nonadsorbing solute. The distribution coefficient (commonly called $K_{d}$ ) is equal to the mass of solute on the solid phase per unit mass of solid phase divided by the concentration of the solute in solution and is generally expressed in milliliters per gram $(\mathrm{mL} / \mathrm{g})$.

Samples of till and trench water were tested at Brookhaven National Laboratory to compare the distribution of radionuclides attached to the solid phase and within the solute (Weiss and Colombo, 1980, p. 145-187). The batch method, in which samples of till and trench water were mixed together and allowed to reach equilibrium, was used to determine the distribution coefficient.

Weiss and Colombo (1980) determined the extent to which batch $K_{d}$ values for several radionuclides were affected by methods of sample handling, experimental procedures, and equipment. They observed that when till samples were disaggregated by ultrasonic methods (which probably has little effect on the natural grainsize distribution) and the trench water was maintained in a strictly anoxic condition, $K_{d}$ values were much lower (adsorption was much less) than when mechanical disaggregation or oxidized trench water were used. Distribution coefficients for four isotopes, derived from a test with anoxic trench water and ultrasonic disaggregation, follow. In the batch tests, ${ }^{85} \mathrm{Sr}$ was evaluated rather than ${ }^{90} \mathrm{Sr}$ to facilitate analyses. Presumably the distribution coefficients of the two isotopes are nearly identical.

\begin{tabular}{|c|c|}
\hline Radionuclides & $\begin{array}{l}\text { Distribution coefficient }\left(K_{d}\right)^{1} \\
(\mathrm{~mL} / \mathrm{g})\end{array}$ \\
\hline${ }^{85} \mathrm{Sr} \ldots$ & $\ldots \ldots .9 \pm 0.4$ \\
\hline${ }^{134} \mathrm{Cs} \ldots$ & …... 49 \\
\hline${ }^{137} \mathrm{Cs} \ldots$ & $\ldots+48$ \\
\hline${ }^{60} \mathrm{Co} \ldots$ & 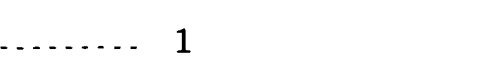 \\
\hline
\end{tabular}

\footnotetext{
${ }^{1}$ From Weiss and Colombo $\left(1980\right.$, p. 173). $K_{d}$ is reported as an average \pm 1 standard deviation of observed results, based on laboratory batch tests with anoxic water from trench 2 and ultrasonic disaggregation of unweathered till from test hole A2. Mixing time was 100 hours in glass containers. Equilibrium $K_{d}$ values would require longer mixing times and would be somewhat larger.
}

Weiss and Colombo (1980, p. 172) speculate that, as trench water migrates away from the burial trenches, admixture with oxygen-bearing ground water might result in higher distribution coefficients and further adsorption of radionuclides. However, the dissolved-oxygen concentration of ground water several tens of meters below the water table is small, commonly approaching zero, as revealed by the reduction of sulfate and increase in dissolved iron (table 1; also LaSala, 1968, p. 60). Furthermore, reducing conditions have been observed for hundreds of meters downgradient from strongly reducing sources such as landfills (Kimmel and Braids, 1980).

\section{MIGRATION RATES}

The migration of radionuclides in ground water is dependent on several processes, mainly convection ground-water flow, hydrodynamic dispersion (the sum of mechanical dispersion and molecular diffusion), and chemical reaction (including reactions between two different fluids, reactions between solutes in the fluid and the earth material, and radioactive decay). Detailed descriptions of these processes are presented by Grisak and Jackson (1978). Because movement of ground water and radionuclides at the burial site has been predominantly in one direction (downward from the trenches), a rather simple one-dimensional solute- 
transport equation was used to quantify the factors that control radionuclide migration. The equation includes convective transport, hydrodynamic dispersion, radioactive decay, and instantaneous equilibrium-controlled reversible sorption. It assumes that (1) density variations are negligible regardless of changes in solute concentration, (2) rate of infiltration and water content of soil are constant, (3) hydrodynamic dispersion coefficient is constant, and (4) linear isotherm conditions prevail.

The basic equation may be written as follows:

$$
\begin{aligned}
\frac{\partial}{\partial t}\left(\theta C_{i}+{ }_{m} \bar{C}_{i}\right)= & \frac{\partial}{\partial x}\left(D^{\prime} \frac{\partial C_{i}}{\partial x}\right)-\frac{\partial}{\partial x}\left(q C_{i}\right) \\
& -k_{i}\left(\theta C_{i}+\rho_{m} \bar{C}_{i}\right)
\end{aligned}
$$

where

$\theta=$ water content of the porous medium, dimensionless;

$C_{i}=$ concentration of nuclide dissolved in water, $M L^{-3}$;

$\bar{C}_{i}=$ concentration of nuclide attached to the solid, $M L^{-3}$;

${ }^{\rho_{m}}=$ dry bulk density or dry unit weight, $M L^{-3}$;

$D^{\prime}=$ hydrodynamic dispersion coefficient, $L^{2} T^{-1}$;

$q \quad=\quad$ specific flux, $L T^{-1}$;

$x=$ distance from source, $L$;

$t=$ time, $T$;

$k_{i}=$ radioactive decay term, $\frac{\ln 2}{t_{h}}, T^{-1}$; and

$t_{h}=$ radionuclide half life, $T$.

The concentration of the radionuclide attached to the solid can be approximated in equation 5 for equilibrium reactions with linear adsorption isotherms as:

$$
\bar{C}_{i}=C_{i} \cdot K_{d}
$$

where

$K_{d}=$ the distribution coefficient, $L^{3} M^{-1}$.

Hydrodynamic dispersion $\left(D^{\prime}\right)$ is the sum of mechanical dispersion and molecular diffusion. Mechanical dispersion is the spreading of a solute with respect to the average flow produced by velocity variations in the pore space; molecular diffusion is the movement of a solute from regions of higher concentrations to regions of lower concentrations and occurs even in the absence of fluid motion (Bear, 1972). The Peclet number was used to determine which of the processes predominates in the till and is defined as follows (Bear, 1972):

$$
P_{e}=\left[\left(V_{0}\right) \cdot d\right] / D_{d}
$$

where

$P_{e}=$ Peclet number, dimensionless;

$d \quad=$ mean grain size or any other characteristic medium length, $L$;

$D_{d}=$ coefficient of molecular diffusion of a solute in the liquid phase, $L^{2} T^{-1}$; and

$V_{0}=$ average linear (pore) velocity, $\frac{q}{\theta}, L T^{-1}$.

The Peclet number of the till at the burial site was estimated to be between $10^{-5}$ and $10^{-6}$ and is based on (1) an average linear velocity of 1 to $8 \mathrm{~cm} / \mathrm{yr}$ as determined from specific fluxes obtained from computer simulations of ground-water flow and an effective porosity of $0.3,(2)$ a mean grain size of $0.0006 \mathrm{~cm}$ as determined from 16 particle-size analyses, and (3) a reasonable molecular diffusion coefficient of major ions in water between $315 \mathrm{~cm}^{2} / \mathrm{yr}$ and $630 \mathrm{~cm}^{2} / \mathrm{yr}$ (Robinson and Stokes, 1955).

According to Bear (1972), a Peclet number less than 1 indicates the zone where molecular diffusion predominates and mechanical dispersion is negligible. Thus, the coefficient of hydrodynamic dispersion in equation 5 was modified from Sherwood and others (1975, p. 40) as shown below:

$$
D^{\prime} \cong D_{d^{\prime}}=\left(D_{d} \cdot \theta\right) / \tau
$$

where

$\tau=$ tortuosity factor, dimensionless, and

$D_{d^{\prime}}=$ effective diffusion coefficient through the till, $L^{2} T^{-1}$.

The tortuosity factor was incorporated to allow for (1) the fact that the distance traveled between two points through the till is greater than a straight line, and (2) the presence of tiny orifice restrictions in solids of complex structure.

Estimates of the diffusion coefficients of a radionuclide through water were obtained from the literature. The water content (porosity) was determined from laboratory tests of the till and averaged 0.3. Thus, the only unknown in equation 8 is the tortuosity factor; it was determined by repeated adjustment along with the average linear (pore) velocity of ground-water flow until calculated concentrations of a selected radionuclide approximated the observed values from samples collected beneath trenches 4,5 , and 8 . 
$\mathrm{Lu}$ (1978) developed the following solution to solve the basic one-dimensional equation (5) that was used to model migration of radionuclides beneath the trenches:

$$
\begin{aligned}
\frac{C_{i}(x, t)}{C_{0}}= & \frac{a}{a+(b / D)^{1 / 2}} \exp \left[\left[a-(b / D)^{1 / 2}\right] x\right] \operatorname{erfc}\left[\frac{x}{2(D t)^{1 / 2}}-(b / t)^{3 / 2}\right]+ \\
& \frac{a}{a-(b / D)^{1 / 2}} \exp \left[\left[a+(b / D)^{1 / 2}\right] x\right] \operatorname{erfc}\left[\frac{x}{2(D t)^{3 / 2}}+(b t)^{1 / 2}\right]+ \\
& \frac{a V}{k_{i}} \exp \left(2 a x-k_{i} t\right) \operatorname{erfc}\left[\frac{x}{2(D t)^{1 / 2}}+a(D t)^{1 / 2}\right]
\end{aligned}
$$

where

$$
\begin{aligned}
x & =\text { distance from the base of the trench, } L \\
t & =\text { time, } T \\
D & =\left(D^{\prime}{ }_{d} / \theta\right) /\left(1+\frac{\rho_{m} K_{d}}{\theta}\right) \\
V & =V_{0} /\left(1+\frac{\rho_{m} K_{d}}{\theta}\right) \\
a & =V /(2 D) \\
b & =\left(k_{i}+a^{2} D\right) ; \text { and }
\end{aligned}
$$$$
\text { the term }\left(1+\frac{\rho_{m} K_{d}}{\theta}\right) \text { is known as the retardation }
$$$$
\text { factor (Freeze and Cherry, 1979). }
$$

The boundary and initial conditions are:

$$
\begin{aligned}
& C_{i}(x, 0)=0 \text { for } 0<x<\infty \text { and } \\
& q(0, t) C_{0}=-D_{d^{\prime}} \partial C / \partial x(0, t)+q(0, t) C_{i}(0, t)
\end{aligned}
$$

where

$C_{0}=$ concentration of radionuclide at $x=0, M L^{-3}$.

Results of calculating the migration of selected radionuclides beneath the trenches are discussed in the following paragraphs.

\section{TRITIUM}

The migration of tritium through the till is thought to occur in the form of tritiated water. The analytical solution previously described was used to simulate the tritium profile beneath trenchs 5 and 8 , assuming that both the rate of ground-water flow across the trench floor and the tritium concentration in the trench remain constant. In addition, the distribution coefficient of tritiated water is assumed to be zero, which results in a retardation factor of 1 . The diffusion coefficient of tritiated water through water was determined experimentally to be about $475 \mathrm{~cm}^{2} / \mathrm{yr}$ at $10^{\circ} \mathrm{C}$ (Wang and others, 1953 , p. 468). The radioactive half-life of tritium is $12.3 \mathrm{yr}$ (Thatcher and others, 1977), and the porosity is constant at 0.3 . Thus, only the average linear velocity and the tortuosity factor were adjusted such that the simulated concentrations of tritium approximated the measured values in the till.

Test holes $8-2 \mathrm{~A}$ and $8-2 \mathrm{~B}$ were initially chosen to simulate the tritium profile beneath trench 8 because (1) the trench-floor depth was known more accurately than at the other sites (Prudic, 1979a), (2) the test holes penetrated fairly uniform till, and (3) the water level in trench 8 had remained nearly constant since the trench was completed. (Trenches 4 and 5 experienced large variations in trench-water levels during the same period.) An acceptable fit to the observed tritium profile was obtained from a specific flux value between 0.30 and $0.45 \mathrm{~cm} / \mathrm{yr}$, which is within the lower range determined from computer simulations of ground-water flow (average linear velocity of 1 to $1.5 \mathrm{~cm} / \mathrm{yr}$ ) and a range of tortuosity from 2.4 to 2.7 (fig. $32 \mathrm{~A}$ ). The effective diffusion coefficient of tritiated water through the till based on equation 8 and a porosity of 0.3 is between 53 and $59 \mathrm{~cm}^{2} / \mathrm{yr}$.

Phillips and Brown (1968) measured the diffusion coefficient of tritiated water through both montmorillonite and kaolinite clays in laboratory experiments and noted that the presence of the clay systems reduced the diffusion coefficient of tritiated water through water by 0.20 to 0.45 of its value. The reduction in the effective diffusion coefficient of tritiated water through the till when compared to the diffusion coefficient of tritiated water through water was between 0.11 and 0.13 . However, the diffusion coefficients measured in the laboratory decreased with increasing (dry) bulk density. The measured diffusion coefficient through kaolinite clay decreased from $344 \mathrm{~cm}^{2} / \mathrm{yr}$ at a bulk density of $0.99 \mathrm{~g} / \mathrm{cm}^{3}$ to $167 \mathrm{~cm}^{2} / \mathrm{yr}$ at a bulk density of $1.4 \mathrm{~g} / \mathrm{cm}^{3}$. A similar decrease was noted from the experiments on montmorillonite clay. In addition, the laboratory experiments were done at a temperature of $18^{\circ} \mathrm{C}$, whereas the temperature of water in the trenches and in the till is closer to $10^{\circ} \mathrm{C}$. Wang and others (1953) showed that a reduction in temperature also reduces the diffusion coefficient of tritiated water through water. Thus, the greater (dry) bulk density of the till (1.82 $\left.\mathrm{g} / \mathrm{cm}^{3}\right)$ than of the laboratory samples, and the lower temperature, probably results in a lower effective diffusion coefficient through the till than those determined experimentally by Phillips and Brown (1968). This suggests that the estimates of the effective diffusion coefficient of tritiated water through the till probably are reasonable.

In the calculations presented in this report, the concentration of tritium in the trench water was assumed constant from the time the trench was closed to the time the samples were collected. The reasonable fit between the calculated and observed values of tritium migration beneath trench 8 at holes 8-2A and 8-2B (as shown in fig. $32 A$ ), based on reasonable values for specific flux, porosity, and tortuosity, suggests that the concentration 
$A$, Holes 8-2A and 8-2B

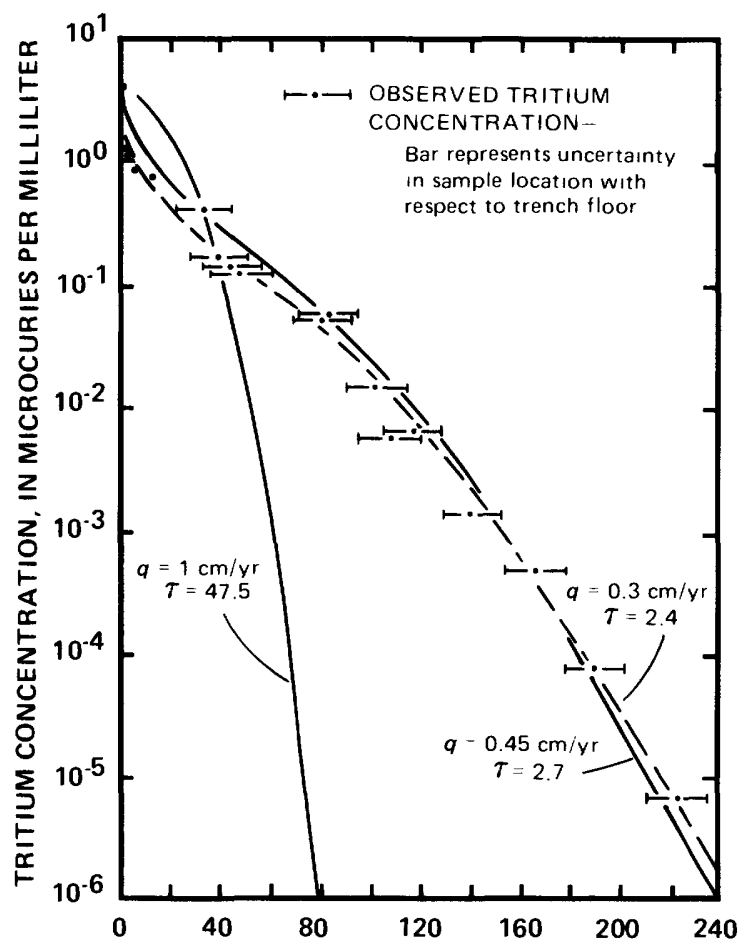

$B$, Hole 8-1C with changes in specific flux

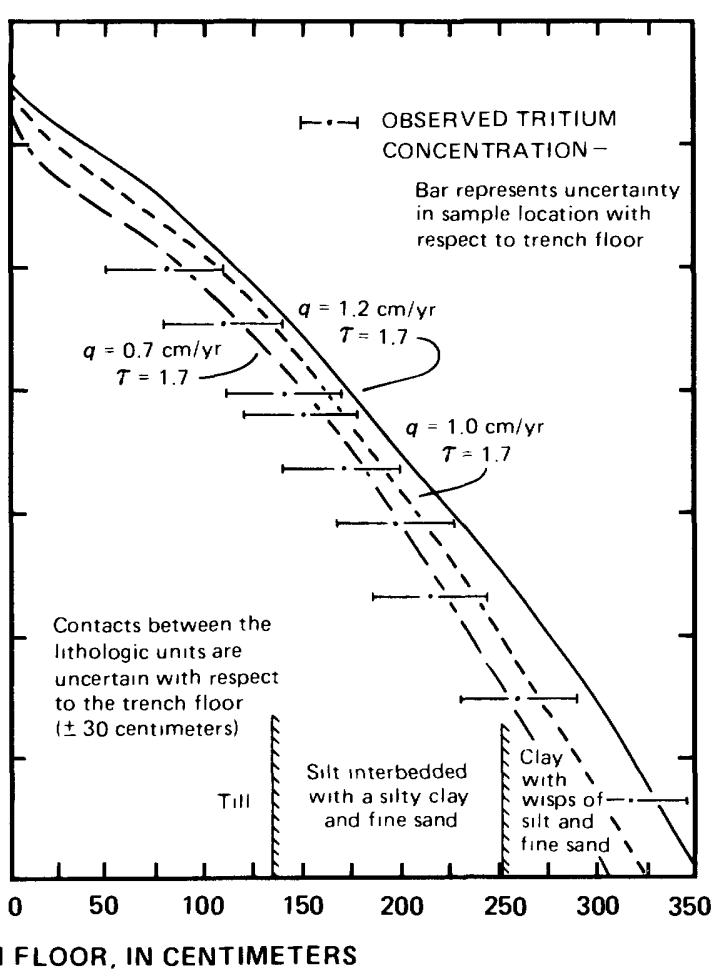

C, Hole 8-1C with changes in tortuosity

D. Holes 5-2D and E

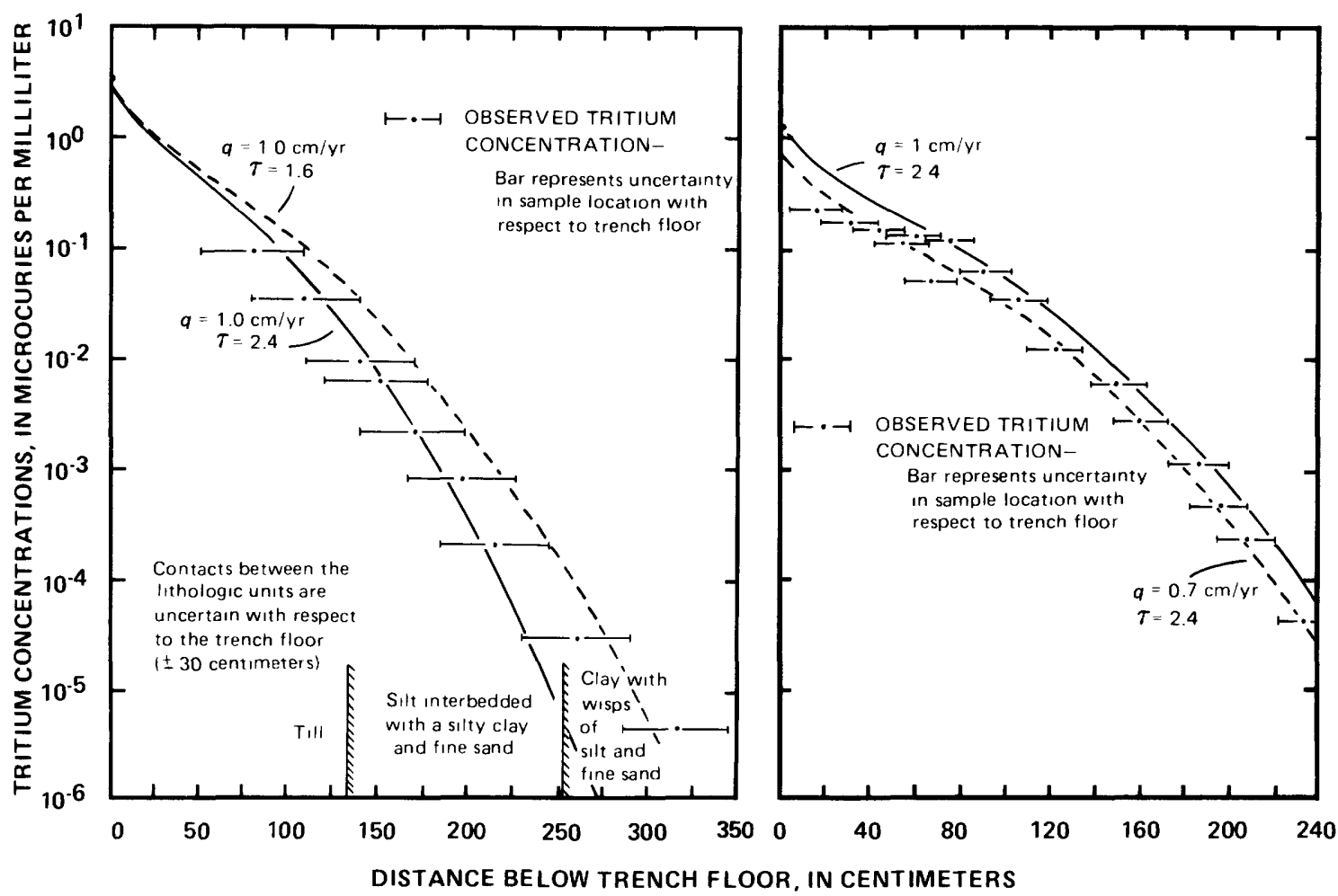

FIGURE 32.-Comparison of observed tritium concentrations with those calculated from an analytical equation with a constant-flux boundary. $A$, Beneath trench 8 in test holes $8-2 \mathrm{~A}$ and $8-2 \mathrm{~B}$. $B$, Beneath trench 8 in test hole 8-1C with changes in specific flux. $C$, Beneath trench 8 in test hole 8-1C with changes in tortuosity. $D$, Beneath trench 5 in test holes 5-2D and E. Location of holes is shown in figure 7. 
of tritium in the trench water has probably remained constant since shortly after the trench was completed in 1971. This contrasts somewhat with the results given in table 13; however, the earlier samples may not represent the true concentration of tritium in trench water because they were collected from either an open trench or an open standpipe, as explained in the earlier section "Sampling methods."

The calculation of the tritium profile at hole 8-1C (fig. $32 B, C$ ) suggests that the specific flux is 0.7 to $1.2 \mathrm{~cm} / \mathrm{yr}$ (average linear velocity is 2.3 to $4 \mathrm{~cm} / \mathrm{yr}$ ), and the tortuosity factor ranges from 1.6 to 2.4. Although these ranges are larger than those calculated for the till at holes $8-2 \mathrm{~A}$ and $8-2 \mathrm{~B}$, they seem reasonable in that at least $2 \mathrm{~m}$ of disturbed lacustrine material was penetrated in hole 8-1C about $1 \mathrm{~m}$ below the trench floor (Prudic, 1979a). The higher permeability of this material should permit greater distances of tritium migration, particularly if the lens intersects the trench floor in the vicinity of hole $8-1 \mathrm{C}$. The slightly smaller tortuosity values are probably related to a less tortuous path through the lacustrine material than through the till. Conversely, it is possible that the higher range in tortuosity factor and the specific flux may be an artifact of estimating the migration rate of tritium by a simple one-medium model (till), when at hole 8-1C, the system has at least two media. Thus, the assumption of a constant tortuosity and a constant specific flux may not be completely valid for this site.

Simulations of tritium migration beneath trench 5 at holes 5-2D and 5-2E suggest that the specific flux is between 0.6 and $1.0 \mathrm{~cm} / \mathrm{yr}$ (average linear velocity of 2 to $3.3 \mathrm{~cm} / \mathrm{yr}$ ), and the tortuosity factor of 2.4 to 2.7 (fig. $32 D$ ). The range in the tortuosity factor is similar to that calculated for the till beneath trench 8 at holes 8-2A and $8-2 \mathrm{~B}$. The specific flux is higher beneath trench 5 than trench 8 at holes $8-2 \mathrm{~A}$ and $8-2 \mathrm{~B}$ and is consistent with the differences between trench-water levels in trenches 5 and 8 . The water level in trench 8 has been consistently low since completion of the trench, whereas the water level in trench 5 has fluctuated by more than 4 $\mathrm{m}$. The specific flux range of 0.6 to $1.0 \mathrm{~cm} / \mathrm{yr}$ represents an average rate over the 9 years from trench completion to sample collection in test holes 5-2D and 5-2E.

The distance between the floor of trench 4 and the top of the tritium profile beneath it in hole 4-4A is not known as exactly as for trenches 5 and 8 (Prudic, 1979a). On the basis of estimates used to calculate tritium migration beneath trench 5 , the distance from the floor of trench 4 to the top of the first core sample is about $85 \mathrm{~cm}$.

Tritium concentations in trench water are unlikely to remain constant at the concentrations measured from
1975-79 for more than 70 years. Kelleher and Michael (1973) estimated from records kept by Nuclear Fuels Services, Inc. that more than 10,000 curies of tritium were buried in containers in trench 5 , but this estimate does not include the approximate 10,000 curies of mixed tritium and ${ }^{14} \mathrm{C}$ nor the 23,000 curies of mixed and miscellaneous radionuclides. Assuming that tritium is the predominant radionuclide in these other categories, the tritium content could be as high as 40,000 curies. The estimated tritium content in trench water before trench 5 was pumped in 1975 was approximately 2,000 curies, as computed from an estimated trench volume of $8.5 \times 10^{6} \mathrm{~L}$, a porosity of 0.25 (Prudic, 1980), and a tritium concentration in trench water of $1 \mu \mathrm{Ci} / \mathrm{mL}$. After the 1980 pumpout of water, the total tritium content in the water was estimated to be 600 curies because of the lesser volume of water. For the tritium content in the trench water to remain constant, tritium in the waste must leach into the water at a rate equal to the decay of tritium in the water, assuming little addition of water to the trench. However, even assuming a tritium content of 40,000 curies in the waste in 1980 , this value after 72 years will have decreased to 600 curies by radioactive decay. If the volume of water in the trench remains constant at the amount estimated in 1980, the maximum tritium concentration of trench water after 120 years could be $6 \times 10^{-2} \mu \mathrm{Ci} / \mathrm{mL}$ and, after 200 years, it could be only $5 \times 10^{-4} \mu \mathrm{Ci} / \mathrm{mL}$, assuming that all tritium in the waste leaches into the water.

The maximum distance tritium would migrate beneath trench 5 after 100 years and still be detected (concentrations greater than $5 \times 10^{-7} \mu \mathrm{Ci} / \mathrm{mL}$ ) is about $10 \mathrm{~m}$, assuming that (1) the tritium in the waste leaches into the trench water at a rate equal to the decay of tritium in the water; (2) the water level in the trench remains constant; (3) the specific flux of water through the till is constant at a rate of $0.7 \mathrm{~cm} / \mathrm{yr}$; (4) the effective porosity is 0.3 ; and (5) the tortuosity factor is 2.4 . Tritium profiles beneath trench 5 after 10 and 100 years are shown in figure 33.

If a specific flux used in the simulation of the tritium profile is $2 \mathrm{~cm} / \mathrm{yr}$ (the upper limit of the range in specific flux estimated for the till beneath the trench), the maximum distance tritium could migrate after 100 years at detectable concentrations is about $14 \mathrm{~m}$ below the trench floor. Thus, tritium is unlikely to migrate through the till to points of discharge unless the trenches fill with water and overflow through the covers. The amount of tritium that reaches the surface environment in the liquid phase is considerably less than the estimated amount of tritiated gases that migrate through the cover or out of open standpipes in the trenches ( $\mathrm{Lu}$ and Matuszek, 1978). 


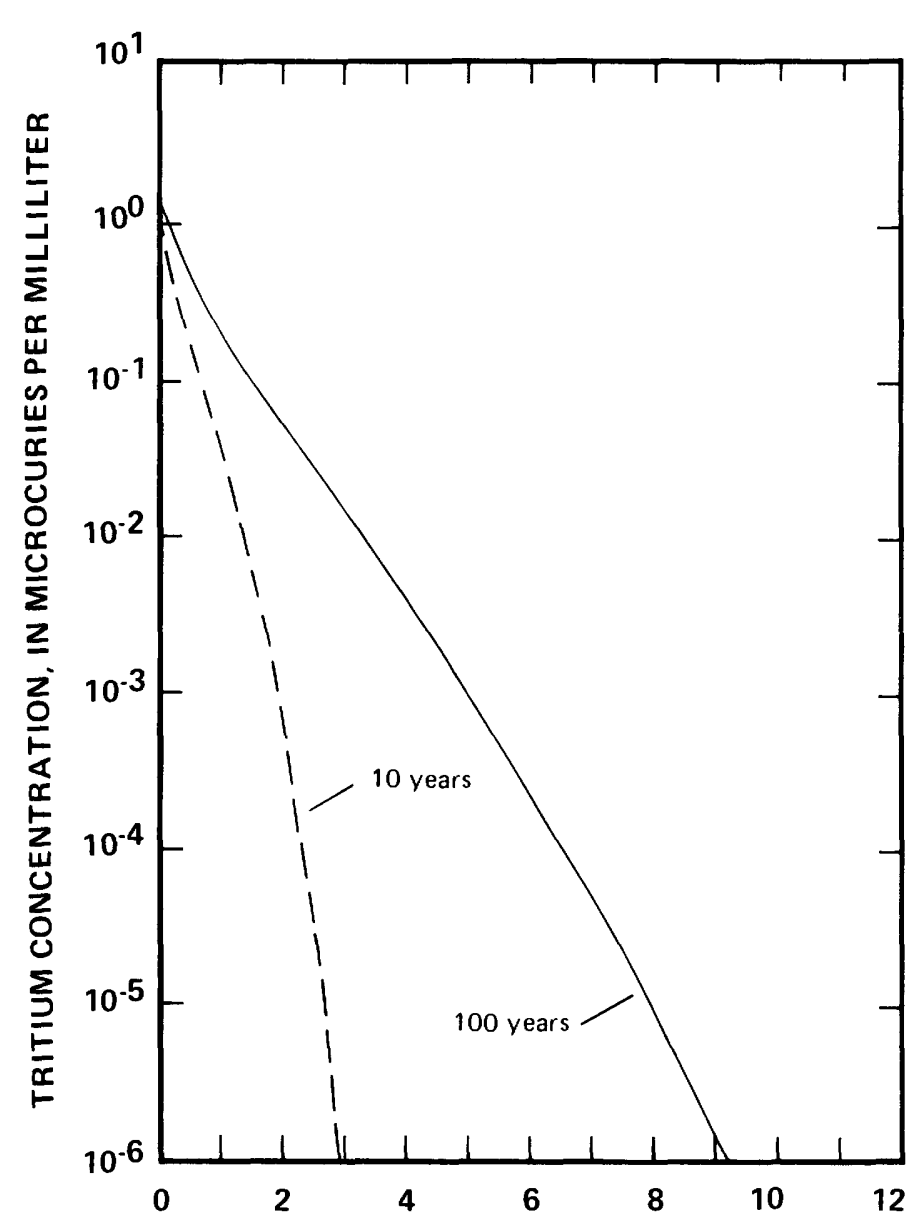

DISTANCE BELOW TRENCH FLOOR, IN METERS

FIGURE 33.-Predicted tritium concentrations beneath trench 5 after 10 and 100 years, assuming a constant concentration of 1.44 $\mu \mathrm{Ci} / \mathrm{mL}$ in trench water; a constant water level in the trench; a porosity $(\theta)$ of 0.3 ; a specific flux $(q)$ of $0.7 \mathrm{~cm} / \mathrm{yr}$; a tortuosity factor $(\tau)$ of 1.6 ; a diffusion coefficient $\left(D_{d}\right)$ of water $475 \mathrm{~cm}^{2} / \mathrm{yr}$; a distribution coefficient $\left(K_{d}\right)$ of $0.0 \mathrm{~mL} / \mathrm{g}$.

\section{STRONTIUM}

The mitration rate of ${ }^{90} \mathrm{Sr}$ was much less than that of tritium, as determined from analyses of core samples from beneath the trenches. The lower rate is attributed to sorption of ${ }^{90} \mathrm{Sr}$ onto the till matrix and perhaps to a smaller diffusion coefficient.

The simulated migration of ${ }^{90} \mathrm{Sr}$ was compared to observed radionuclide concentrations in core samples of till from beneath trench 8 at test hole 8-2B. The same analytical equation that was used in the simulation of tritium migration was used to simulate ${ }^{90} \mathrm{Sr}$ migration. The analytical equation assumes a constant flow rate at the trench boundary, negligible density variations due to changes in solute concentration, a constant specific flux and diffusion coefficient, a constant concentration of ${ }^{90} \mathrm{Sr}$ in the trench water, and linear isotherm conditions.
Simulations of ${ }^{90} \mathrm{Sr}$ migration beneath trench 8 assumed a specific flux of $0.45 \mathrm{~cm} / \mathrm{yr}$ and a tortuosity value of 2.4. These values were derived from the simulation of tritium migration and were assumed constant for ${ }^{90} \mathrm{Sr}$. The porosity (water-filled void volume) was 0.30 , and the dry bulk density was $1.82 \mathrm{~g} / \mathrm{cm}^{3}$; both are averages from laboratory tests. The distribution coefficient of strontium used in the analyses was $6.9 \mathrm{~mL} / \mathrm{g}$ (Weiss and Colombo 1980), the value listed in the section "Distribution coefficients of selected radionuclides." A half-life of 28.1 years for ${ }^{90} \mathrm{Sr}$ was obtained from Ames and Rai (1978).

The diffusion rate of ${ }^{90} \mathrm{Sr}$ through the till depends on the concentrations of dissolved chemical constituents in the trench water as well as in the pore water in the till and the adsorption of ${ }^{90} \mathrm{Sr}$ from the solute to the till. The diffusion coefficient of several salts in aqueous solutions at temperatures from $10^{\circ} \mathrm{C}$ to $25^{\circ} \mathrm{C}$ ranged from $0.4 \times 10^{-5}$ to $2.3 \times 10^{-5} \mathrm{~cm}^{2} / \mathrm{s}$ (Sherwood and others, 1975). The interaction of ions in a multi-ion system may affect results significantly when the several ion conductances differ greatly, but where ion conductances are similar, no significant error is introduced by the use of "molecular" diffusion coefficients for the species present (Sherwood and others, 1975). Assuming that the ion conductances in the trench water are similar and that the mutual diffusion of $\mathrm{SrCl}_{2}$ salt is similar to that of $\mathrm{CaCl}_{2}$, the diffusion coefficient of ${ }^{90} \mathrm{Sr}$ in aqueous solutions is about $1 \times 10^{-5} \mathrm{~cm}^{2} / \mathrm{s}$, or $315 \mathrm{~cm}^{2} / \mathrm{yr}$. The effective diffusion coefficient $\left(D_{d}{ }^{\prime}\right)$ of ${ }^{90} \mathrm{Sr}$ in the till is then about 39 $\mathrm{cm}^{2} / \mathrm{yr}$ assuming a value of tortuosity equal to 2.4 .

Concentrations of ${ }^{90} \mathrm{Sr}$ measured in the till beneath the trenches (table 16) are the sum of the quantities dissolved in the water and adsorbed to the till; thus, to compare the observed results with calculated values, the analytical solution of $\mathrm{Lu}(1978, \mathrm{p} .40)$ was modified to calculate total concentrations rather than dissolved concentations at any given point along the flow path. A profile of ${ }^{90} \mathrm{Sr}$ concentration beneath trench 8 at hole $8-2 \mathrm{~B}$ was simulated from the values and assumptions previously explained. The simulated profile approximated the observed ${ }^{90} \mathrm{Sr}$ data for the first $30 \mathrm{~cm}$ below the trench floor (fig. 34) but did not reproduce the secondary peak indicated between 40 to $50 \mathrm{~cm}$ below the trench floor. The secondary peak was probably caused by contamination of the sample during collection because the samples were collected in the presence of trench water, as previously explained in the section "Downward migration." As a result of probable sample contamination, and also because of the uncertainty of some analyses with respect to the trench-floor depth, the simulations suggest that the distribution coefficient could range from 1 to $7 \mathrm{~mL} / \mathrm{g}$ and that the effective diffusion coefficient could vary by at least a factor of 2 and still partly reproduce the observed data in the first 30 $\mathrm{cm}$ below the trench floor. 
Because data on migration of ${ }^{90} \mathrm{Sr}$ beneath trench 4 in hole 4-4A were limited, the effective diffusion coefficients used to simulate ${ }^{9} \mathrm{Sr}$ migration beneath trench 8 were used to simulate the ${ }^{90} \mathrm{Sr}$ migration beneath trench 4. Estimates of the distance from the trench floor to where the samples were collected in hole $4-4 \mathrm{~A}$ were obtained from an estimate of the trench-floor altitude (Prudic, 1979a) and from simulation of the observed tritium concentrations in hole 4-4A from values of specific flux and tortuosity obtained in the simulations of tritium concentrations in holes 5-2D and 5-2E beneath trench 5 . The simulated ${ }^{90} \mathrm{Sr}$ concentrations beneath trench 4 approximated the field data when a distribution coefficient of $1 \mathrm{~mL} / \mathrm{g}$, a specific flux of $1.2 \mathrm{~cm} / \mathrm{yr}$, and a tortuosity factor of 2.4 were used (fig. 35), but because of the uncertainty in the distance between the trench floor and the sample-collection point, the distribution coefficient could range from 1 to $3 \mathrm{~mL} / \mathrm{g}$, the specific flux could range from 0.3 to $1.2 \mathrm{~cm} / \mathrm{yr}$, and the tortuosity factor could range from 1.6 to 2.4 . The range in an effective diffusion coefficient $\left(D_{d}{ }^{\prime}\right)$ is from 39 to 59 $\mathrm{cm}^{2} / \mathrm{yr}$.

The maximum distance that ${ }^{90} \mathrm{Sr}$ could migrate downward beneath trench 4 and still be detected in the till is about $6 \mathrm{~m}$ (fig. 36), assuming that (1) the ${ }^{90} \mathrm{Sr}$ in the wastes in trench 4 leaches into the trench water at a rate equal to radioactive decay of strontium in the water for 500 years; (2) the water level in trench 4 remains constant; (3) the specific flux is constant at a rate of $1 \mathrm{~cm} / \mathrm{yr}$; (4) the effective porosity (water-filled void volume) is 0.3 ; (5) the tortuosity factor is constant at 1.6 , which results in an effective diffusion coefficient of ${ }^{90} \mathrm{Sr}$ in the till of $59 \mathrm{~cm}^{2} / \mathrm{yr}$; (6) the distribution coefficient is constant at $1 \mathrm{~mL} / \mathrm{g}$; (7) the dry bulk density is $1.82 \mathrm{~g} / \mathrm{cm}^{3}$; and (8) the radioactive half life of ${ }^{90} \mathrm{Sr}$ is 28.1 years. The actual distance that ${ }^{90} \mathrm{Sr}$ will migrate through the till is probably less then the estimate of $6 \mathrm{~m}$ because (1) the concentration of ${ }^{90} \mathrm{Sr}$ will not remain constant over a 500-year period-radioactive decay will greatly reduce the amount of ${ }^{90} \mathrm{Sr}$ in the wastes and in the trench water;
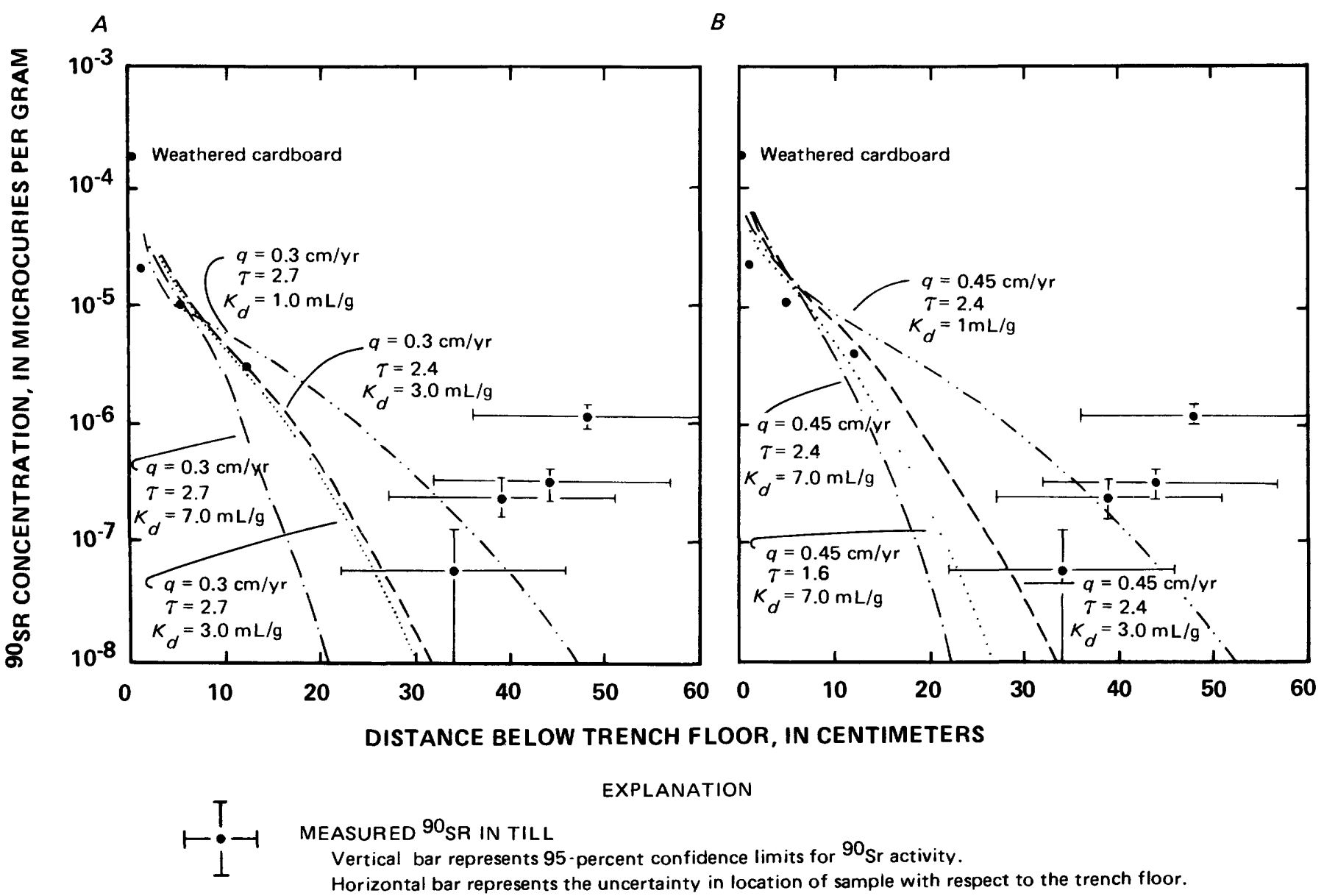

FIGURE 34.-Comparison of observed and calculated ${ }^{\circ} \mathrm{Sr}$ concentrations beneath trench 8 in test hole 8-2B assuming a constant concentration of ${ }^{90} \mathrm{Sr}$ in trench water, a constant water level in the trench, a porosity $(\theta)$ of 0.3 , and a dry bulk density $\left(\boldsymbol{\rho}_{m}\right)$ of $1.82 \mathrm{~g} / \mathrm{cm}^{3} . A$, Specific flux $(q)$ is constant at $0.3 \mathrm{~cm} / \mathrm{yr}$ while the distribution coefficient $\left(K_{d}\right)$ ranges from 1.0 to $7.0 \mathrm{~mL} / \mathrm{g}$ and the tortuosity factor $(\tau)$ ranges from 2.4 to 2.7 . $B$, Specific flux $(q)$ is constant at $0.45 \mathrm{~cm} / \mathrm{yr}$ while the distribution $\left(K_{d}\right)$ ranges from 1.0 to $7.0 \mathrm{~mL} / \mathrm{g}$ and the tortuosity factor $(\tau)$ ranges from 1.6 to 2.4 . 
(2) the estimate of the effective diffusion coefficient of ${ }^{90} \mathrm{Sr}$ in the till is the upper limit of the range estimated for ${ }^{90} \mathrm{Sr}$; and (3) the distribution coefficient is the lower limit estimated from scant data of ${ }^{90} \mathrm{Sr}$ concentrations in the till. For example, if the tortuosity factor is increased to 2.4 and the distribution coefficient is increased to $3 \mathrm{~mL} / \mathrm{g}$, the estimated distance that ${ }^{9} \mathrm{Sr}$ would migrate is less than $3 \mathrm{~m}$ after 500 years. These calculations therefore indicate that ${ }^{90} \mathrm{Sr}$ will not migrate by ground water through the till to points of discharge.

\section{CARBON}

In general, most of the longer lived radionuclides in trench water such as ${ }^{239,240} \mathrm{Pu},{ }^{129} \mathrm{I}$, and ${ }^{241} \mathrm{Am}$ are present only in very small amounts (table 15; also Davis and Fakundiny, 1978; Husain and others, 1979; Dana and others, 1979 and 1980; Weiss and Colombo, 1980). Most longer lived radionuclides are unlikely to migrate far from the trenches and still be detectable because (1) their concentration in the trench water is low and diffusion will not be effective, and (2) they have an affinity to the clay particles in the till. The only longer lived radionuclide having a concentration considerably above detection limits in trench water is ${ }^{14} \mathrm{C}$.

Trench water contains both inorganic and organic carbon. The concentration of organic ${ }^{14} \mathrm{C}$ is about 10 times higher than that of inorganic ${ }^{14} \mathrm{C}$ (table 15). However, much of the organic carbon in the trench water is converted by bacterial decomposition into methane and carbon dioxide gases (Lu and Matuszek, 1978; and Kunz, 1982).

Analyses of cores from beneath trench 5 indicate that ${ }^{14} \mathrm{C}$ has migrated beneath that trench (table 16). However, the distance that ${ }^{14} \mathrm{C}$ can migrate through till

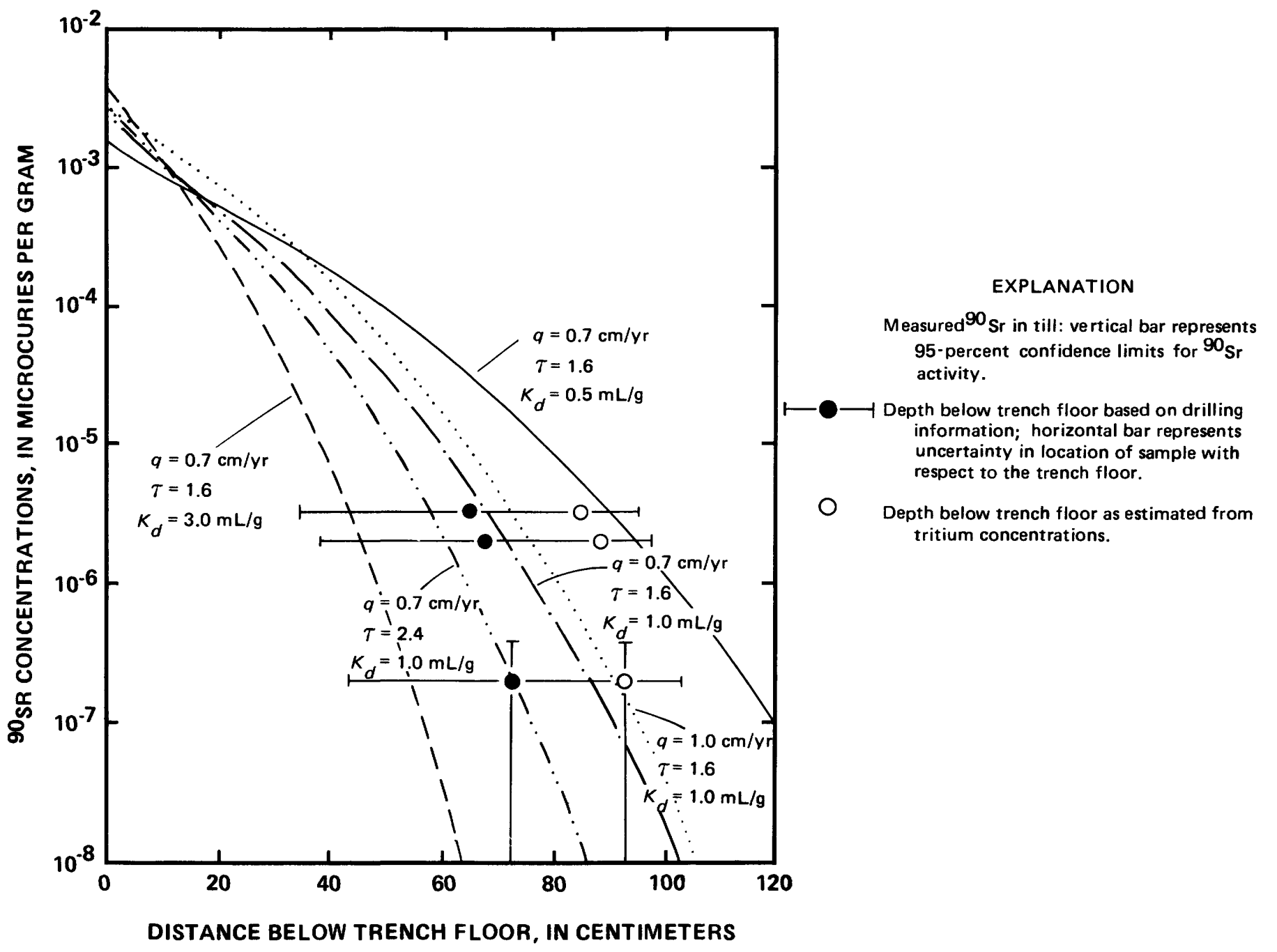

FIGURE 35.-Comparison of observed and calculated ${ }^{\circ} \mathrm{Sr}$ concentrations beneath trench 4 in test hole 4-4A assuming a constant concentration of ${ }^{90} \mathrm{Sr}$ in trench water, a constant water level in trench, a porosity $(\theta)$ of 0.3 , a dry bulk density $\left(\rho_{m}\right)$ of $1.82 \mathrm{~g} / \mathrm{cm}^{3}$, a specific flux $(q)$ that ranges from 0.7 to $1.0 \mathrm{~cm} / \mathrm{yr}$, a tortuosity factor $(\tau)$ that ranges from 1.6 to 2.4 , and a distribution coefficient $\left(K_{d}\right)$ that ranges from 1.0 to $7.0 \mathrm{~mL} / \mathrm{g}$. 
can be only roughly estimated because the diffusion coefficient of its various forms and its mechanisms of exchange or reaction with the till matrix or the pore water are unknown.

Laboratory experiments to determine the distribution coefficients of ${ }^{14} \mathrm{C}$ in the till were conducted by the New York State Health Department, Radiological Sciences Laboratory (Charles Kunz, 1981, written commun.). The first step was to vigorously mix $100 \mathrm{~mL}$ of anoxic trench water from trenches 5 and 8 with $20 \mathrm{~g}$ of uncontaminated till for 24 hours in an argon atmosphere. The samples were then filtered. A fourth of the filtrate was used for analysis, and the remainder was mixed with another $20 \mathrm{~g}$ of uncontaminated till for 24 hours and then analyzed. The organic ${ }^{14} \mathrm{C}$ showed little exchange with the till ( $K_{d}$ values ranged from 0.7 to $1.1 \mathrm{~mL} / \mathrm{g}$ ); the inorganic ${ }^{14} \mathrm{C}$ showed somewhat more exchange $\left(K_{d}\right.$ values ranged from 3 to $12 \mathrm{~mL} / \mathrm{g}$ ).

The analytical equation and assumptions that were used to simulate tritium and ${ }^{90} \mathrm{Sr}$ migration beneath the trenches were also used to simulate the migration of ${ }^{14} \mathrm{C}$ beneath trench 5 . An estimate of the time required for a detectable concentration (approximately $1 \times 10^{-7} \mu \mathrm{Ci} / \mathrm{g}$ ) of ${ }^{14} \mathrm{C}$ in the till to migrate vertically $23 \mathrm{~m}$ through the till to the underlying lacustrine sequence is between 1,500 and 20,000 years, assuming that (1) the diffusion coefficient of ${ }^{14} \mathrm{C}$ through water in the form of bicarbonate is $315 \mathrm{~cm}^{2} / \mathrm{yr}$; (2) the tortuosity factor ranges from 1.6 to 2.4 ; (3) the distribution coefficient ranges from 1 $\mathrm{mL} / \mathrm{g}$ to $3 \mathrm{~mL} / \mathrm{g}$; (4) the specific flux ranges from 0.3 to $2.0 \mathrm{~cm} / \mathrm{yr}$; (5) the water level in the trench and the heads in the till remain constant; (6) the effective porosity is 0.3 ; (7) the dry bulk density is $1.82 \mathrm{~g} / \mathrm{cm}^{3}$; and (8) the radioactive half life of ${ }^{14} \mathrm{C}$ is 5,730 years (Thatcher and others, 1977). The time required for ${ }^{14} \mathrm{C}$ to migrate from there laterally through the saturated silts in the lacustrine sequence to points of ground-water discharge is unknown but would add considerably to the length of time that ${ }^{14} \mathrm{C}$ is isolated from the surface environment.

The amount of ${ }^{14} \mathrm{C}$ that might eventually migrate through the till to points of discharge is far less than the amount estimated to migrate through the trench cover or open standpipes in the form of methane and carbon dioxide gases (Lu and Matuszek, 1978; Matuszek, 1980; and Kunz, 1982), or the amount that could migrate through the trench covers once the trenches become filled with water.

\section{SUMMARY AND CONCLUSIONS}

About $67,000 \mathrm{~m}^{3}$ of low-level radioactive waste is buried in western New York in a clay-rich till containing few stones. The till is a valley facies that is widely distributed in Cattaraugus Creek basin below the level

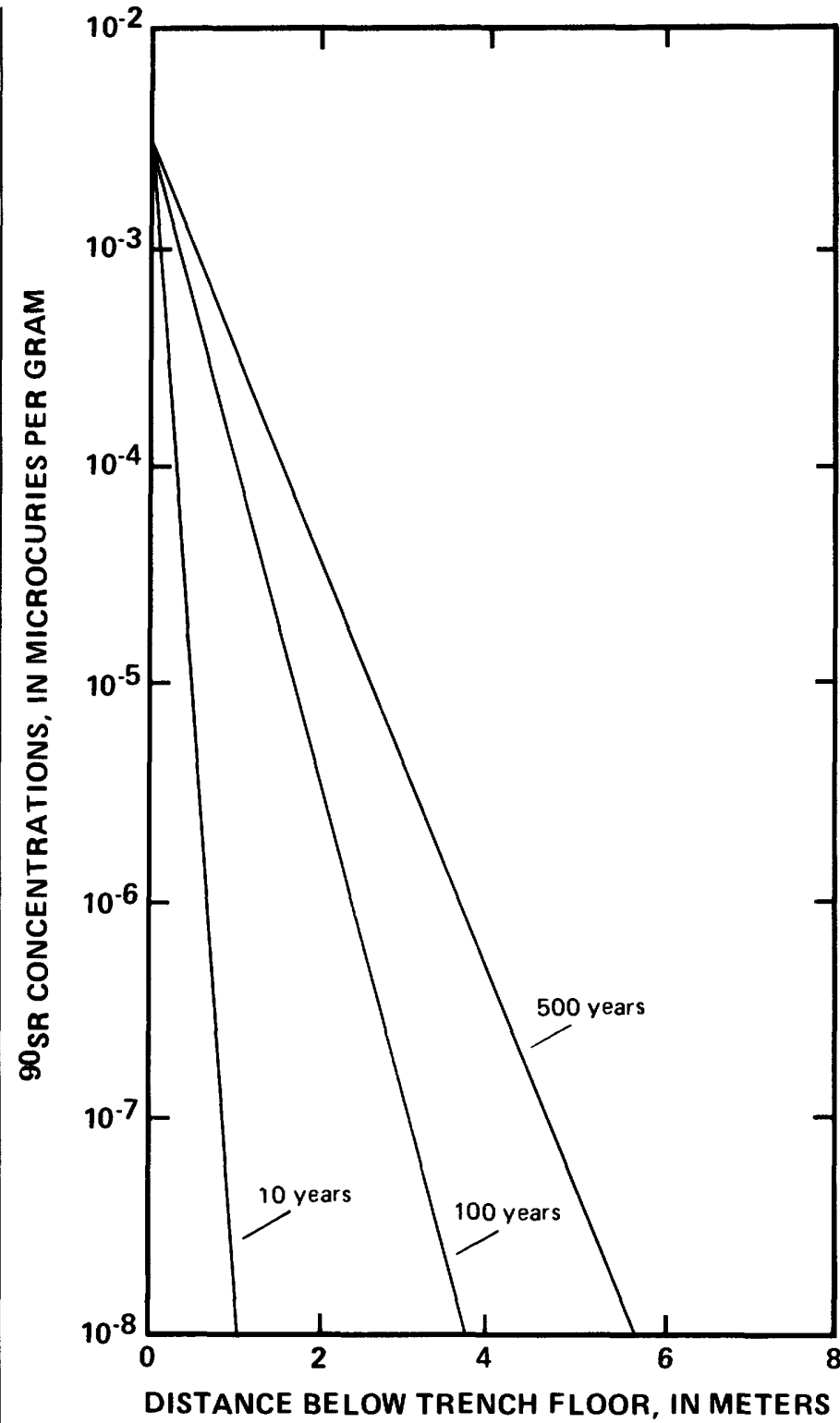

FIGURE 36.-Predicted ${ }^{90} \mathrm{Sr}$ concentrations in till beneath trench 4 after 10,100 , and 500 years assuming a constant concentration of $8.6 \mu \mathrm{Ci} / \mathrm{mL}$ in trench water, a constant water level in the trench, a porosity $(\theta)$ of 0.3 , a dry bulk density $\left(\rho_{m}\right)$ of $1.82 \mathrm{~g} / \mathrm{cm}^{3}$, a specific flux $(q)$ of $1.0 \mathrm{~cm} / \mathrm{yr}$, a tortuosity factor $(\tau)$ of 1.6 , a diffusion coefficient $\left(D_{d}\right)$ of ${ }^{9} \mathrm{Sr}$ of $315 \mathrm{~cm}^{2} / \mathrm{yr}$, a distribution coefficient $\left(K_{d}\right)$ of $1 \mathrm{~mL} / \mathrm{g}$, and a detection limit of ${ }^{90} \mathrm{Sr}$ in the till of $1 \times 10^{-8} \mu \mathrm{Ci} / \mathrm{mL}$.

of saddles in the drainage divide south of the burial ground and was probably deposited by an ice sheet partly suspended in ponded water. At the burial site, the till is about $28 \mathrm{~m}$ thick and overlies a lacustrine sequence, 10 to $20 \mathrm{~m}$ thick, of layered fine sand and silt that is locally capped by a gravel. The upper part of the lacustrine sequence is unsaturated, at least east and south of the burial ground. Bedrock may be as deep as $150 \mathrm{~m}$ below land surface. The till contains about 7 percent severly deformed, discontinuous beds of silt to very fine sand and, rarely, coarser sand and gravel. Fractures 
and root tubes with oxidized and (or) reduced till in their walls extend as much as $5 \mathrm{~m}$ below the original land surface. Late-glacial fluvial gravel caps the till over much of Buttermilk Creek valley but is mostly absent at the burial ground.

Most precipitation at the site either runs off to nearby streams or returns to the atmosphere by evapotranspiration. The small amount that infiltrates the till moves predominantly downward, even beneath small streams bordering the site. Low heads occur within the till where steep and (or) smooth slopes and lack of vegetation cause rapid runoff; higher heads occur where water accumulates on top of the till, primarily in natural depressions and in remnants of late-glacial fluvial gravel, but also beneath trenches that have had a history of water-level rises.

Computer simulation of ground-water flow at the burial ground indicates that the hydraulic conductivity of the till decreases with depth as a result of consolidation from overburden pressures and the lack of fracturing with depth. Simulated decreases in hydraulic conductivity due to overburden pressures were consistent with consolidometer tests of four core samples that showed a decrease in hydraulic conductivity while applied pressure was increased. The specific flux of ground water is between 0.3 and $2.3 \mathrm{~cm} / \mathrm{yr}$, with perhaps slightly higher rates in the weathered till along the slopes bordering the burial site.

Computer simulations indicate that water seeping out of the trenches would not intersect any of the nearby streams. However, if the water level in the trenches were to rise into the reworked till covering them, the trench water could seep out through the cover to land surface. Geohydrologic data indicate little chance that the bedded silt and sand just below the floor of trench $8 \mathrm{ex}$ tends as far as Franks Creek, 75 m west of the trench. Computer simulations suggest that even if this layer were extensive and the trench were filled with water to the base of the cover, water seeping outward through the trench walls would not move more than $18 \mathrm{~m}$ laterally through the silt before it would begin to move downward. Calculations suggest that water leaving the trench would take between 300 and 2,300 years to travel $23 \mathrm{~m}$ downward through the till to the underlying lacustrine unit. From there, the shortest distance to surface discharge would be about $840 \mathrm{~m}$, which would perhaps require an additional 500 years of lateral flow through silt.

In the older (north) trenches, water began to collect after the dry summer of 1971 , overflowed briefly from two trenches in 1975, and was pumped out of several trenches during 1975-77. Water levels rose abruptly during major rainstorms in mid-1975 in trench 5, which indicates rapid infiltration through cracks in the cover material. The newer (south) trenches, except trench 14, maintained low water levels until after the dry summer of 1978 , when water levels began to rise noticeably in four of the seven trenches. The water-level rise in these trenches does not seem related to ground-water inflow but rather to increased infiltration of precipitation through the trench cover. The increase in infiltration rate is attributed to inflow through cracks, which during the dry summer of 1978 were enlarged by desiccation.

Tritium, the most abundant and mobile radionuclide in the trenches, migrated at most $3 \mathrm{~m}$ outward and downward from the trenches 4,5 , and 8 during the first 7 to 11 years after the trenches were completed. Calculations of tritium migration beneath the trenches suggests that molecular diffusion controls the migration rate. The distance that detectable concentrations of tritium could migrate downward from the trenches is predicted to be between 10 and $14 \mathrm{~m}$. Other radionuclides have migrated lesser distances. Calculations of ${ }^{\circ 0} \mathrm{Sr}$ migration beneath the trenches suggests that it may migrate between 3 and $6 \mathrm{~m}$ in the till in 500 years. The only longer lived radionuclide in trench water having a concentration considerably above detection limit is ${ }^{14} \mathrm{C}$. The time for detectable concentration of ${ }^{14} \mathrm{C}$ to migrate through the $23 \mathrm{~m}$ of till is estimated to be 1,500 to 20,000 years.

Subsurface migration of radionuclides from the trenches is severely limited by (1) the topographic setting of the burial ground, which controls recharge; (2) the deeper lacustrine sequence, which acts as a drain to the till; (3) the isotropy and low hydraulic conductivity of the till; and (4) the ion exchange of many of the radionuclides with the clays in the till. In conclusion, radionuclides are far less likely to reach the environment through subsurface migration than by the saturation and overflow of the trenches, which can occur when cracks breach the cover and serve as avenues of rapid recharge, or by the migration of tritium and ${ }^{14} \mathrm{C}$ in the form of carbon dioxide and methane gases through the covers or open standpipes in the trenches.

\section{REFERENCES CITED}

Ames, L. L., and Rai, Dhanpat, 1978, Radionuclide interactions with soil and rock media: U.S. Environmental Protection Agency, EPA 520/6-78-007A, v. 1, 379 p.

Apgar, M. A., and Langmuir, Donald, 1971, Ground-water pollution potential of a landfill above the water table: Ground Water, v. 9 , no. 6 , p. 76-96.

Archer, R. J., LaSala, A. M., Jr., and Kammerer, J. C., 1968, Chemical quality of streams in the Erie-Niagara basin, New York: New York State Conservation Department Basin Planning Report ENB-4, 104 p.

Bear, Jacob, 1972, Dynamics of fluids in porous media: New York, American Elsevier, 764 p. 
Bondietti, E. A., Reynolds, S. A., and Shanks, M. H., 1975, Interactions of plutonium with complexing substances in soils and natural waters: International Atomic Energy Agency, IAEASM-199/51, p. 273-287.

Boothroyd, J. C., Timson, B. S., and Dana, R. H., Jr., 1979, Geomorphic and erosion studies at the Western New York Nuclear Service Center, West Valley, New York: Albany, N.Y., New York State Geological Survey, NUREG/CR-0795, 66 p.

Calkin, P. E., Hodge, D. S., Champion, D. E., Oaksford, E. T., and Palmer, E. C., 1974, Gravity delineation of the preglacial Cazenovia River valley, western New York, U.S.A.: Zeitschrift für Geomorphologie, N.F.; Bd. 18, Heft 3, p. 247-259.

Chadwick, G. H., 1933, Preliminary list of titles and abstracts of papers to be offered at 46th annual meeting, in Geological Society of America, 46th annual meeting, Chicago, Ill., Proceedings, p. $19,82,83,84$. Also see Geological Society of America Bulletin, v. 46 , no. 2 , p. 351 .

Colombo, Peter, and Weiss, A. J., 1979, Evaluation of isotope migrationland burial, water chemistry at commercially operated low-level radioactive-waste disposal sites: Upton, N.Y., Brookhaven National Laboratory, Department of Nuclear Energy, Progress Report 9, BNL-NUREG-50965, 29 p.

Colombo, Peter, Weiss, A. J., and Francis, A. J., 1978a, Evaluation of isotope migration-land burial, water chemistry at commercially operated low-level radioactive-waste disposal sites: Upton, N.Y., Brookhaven National Laboratory, Department of Nuclear Energy, Progress Report 7, BNL-NUREG- 50861, 26 p. $-1978 \mathrm{~b}$, Evaluation of isotope migration-land burial, water chemistry at commercially operated low-level radioactive-waste disposal sites: Upton, N.Y., Brookhaven National Laboratory, Department of Nuclear Energy, Progress Report 8, BNLNUREG-50937, $42 \mathrm{p}$.

Cooper, H. H., Jr., Bredehoeft, J. D., and Papadopulos, S. S., 1967, Response of a finite-diameter well to an instantaneous charge of water: Water Resources Research, v. 3, p. 263-269.

Dana, R. H., Jr., Fakundiny, R. H., LaFleur, R. G., Molello, S. A., and Whitney, P. R., 1979, Geologic study of the burial medium at a low-level radioactive waste-burial site at West Valley, N.Y.: New York State Geological Survey Open-File Report 79-2411, $70 \mathrm{p}$.

Dana, R. H., Jr., Molello, S. A., Fakundiny, R. H., Matuszek, J. M., and $\mathrm{Lu}, \mathrm{A}$. H., 1978, Determination of retention of radioactive and stable nuclides by fractured rock and soil at West Valley, N.Y., phase II: New York State Geological Survey Open-File Report 78-2403, approx. $450 \mathrm{p}$.

Dana, R. H., Jr., Ragan, V. S., Molello, S. A., Bailey, H. H., Fickies, R. H., and Fakundiny, R. H., 1980, General investigation of radionuclide retention and migration pathways at the West Valley, New York low-level burial site: Albany, N.Y., New York State Geological Survey, NUREG/CR-1565, 141 p.

Davis, J. F., and Fakundiny, R. H., 1978, Determination of the retention of radioactive and stable nuclides by fractured rock and soil at West Valley, N.Y., part 1: New York State Geological Survey Open-File Report 78-2401, 377 p.

de Laguna, Wallace, 1972, Hydraulic fracturing test at West Valley, New York: Oak Ridge, Tenn., Oak Ridge National Laboratory, ORNL-4827, 62 p.

Domenico, P. A., and Mifflin, M. D., 1965, Water from low-permeability sediments and land subsidence: Water Resources Research, v. 1, p. $563-576$.

Duckworth, J. P., Jump, M. J., and Knight, B. E., 1974, Low-level radioactive waste management research project-final report: West Valley, N.Y., Nuclear Fuels Services, Inc., 57 p.

Ehlke, T. A., 1979, Effects of landfill leaching on water quality and biology of a nearby stream, South Cairo, Greene County, New
York: U.S. Geological Survey Water-Resources Investigations $79-13,18 \mathrm{p}$.

Fickies, R. H., Fakundiny, R. H., and Mosely, E. T., 1979, Geotechnical analysis of soil samples from test trench at Western New York Nuclear Service Center, West Valley, New York: Albany, N.Y., New York State Geological Survey, NUREG/CR-0644, 21 p.

Finlayson, B. A., Nelson, R. W., and Baca, R. G., 1978, A preliminary investigation into the theory and techniques of modeling the natural moisture movement in unsaturated sediments: Richland, Washington, Rockwell International, Inc., Rockwell Hanford Operations, Energy Systems Group, 144 p.

Freeze, R. A., and Cherry, J. D., 1979, Ground water: Englewood Cliffs, N.J., Prentice Hall, 604 p.

Giardina, P. A., DeBonis, M. F., Eng, Jeanette, and Meyer, G. L., 1977, Summary report on the low-level radioactive waste-burial site, West Valley, New York (1963-1975): U.S. Environmental Protection Agency 902/4-77-010, 122 p.

Grisak, G. E., and Cherry, J. A., 1975, Hydrologic characteristics and response of fractured till and clay confining a shallow aquifer: Canadian Geotechnical Journal, v. 12, no. 1, p. 23-43.

Grisak, G. E., and Jackson, R. E., 1978, An appraisal of the hydrogeological processes involved in shallow subsurface radioactive waste management in Canadian terrain: Ottawa, Canada, Inland Waters Directorate, Water Resources Branch, Scientific Series no. 84, 194 p.

Harding, W. E., and Gilbert, B. K., 1968, Surface water in the ErieNiagara basin, New York: New York State Department of Environmental Conservation Basin Planning Report ENB-2, 118 p.

Hughes, G. M., Landon, R. A., and Farvolden, R. N., 1971, Hydrogeology of solid-waste disposal sites in northeastern Illinois: U.S. Environmental Protection Agency, SW-12d, 154 p.

Humphrey, T. G., and Tingey, F. H., 1978, The subsurface migration of radionuclides at the radioactive waste management complex 1976-1977: Idaho Falls, E G and G Idaho, Inc., Idaho National Engineering Laboratory, Tree-1171, 98 p.

Husain, Liaquat, Matuszek, J. M., Hutchinson, J. A., and Wahlen, Martin, 1979, Chemical and radiochemical character of a low-level radioactive waste-burial site, in Carter, M. W., Kahn, Bernd, and Moghissi, A. A., eds., Management of low-level radioactive waste: New York, Pergamon Press, v. 2, p. 883-900.

Hvorslev, M. J., 1951, Time lag and soil permeability in ground-water observations: Vicksburg, Miss., U.S. Army Corps of Engineers Experimental Station, Bulletin $36,50 \mathrm{p}$.

Kelleher, W. J., 1979, Water problems at the West Valley site, in Carter, M. W., Kahn, Bernd, and Moghissi, A. A., eds., Management of low-level radioactive waste: New York, Pergamon Press, v. 2 , p. $843-851$

Kelleher, W. J., and Michaels, E. J., 1973, Low-level radioactive-waste burial site inventory for the West Valley site, Cattaraugus County, N.Y.: Albany, N.Y., New York State Department of Environmental Conservation, $17 \mathrm{p}$.

Kimmel, G. E., and Braids, O. C., 1980, Leachate plumes in ground water from Babylon and Islip landfills, Long Island, New York: U.S. Geological Survey Professional Paper 1085, 38 p.

Kohnke, Helmut, 1968, Soil Physics: New York, McGraw-Hill, 224 p.

Ku, H. F. H., Randall, A. D., and MacNish, R. D., 1975, Streamflow in the New York part of the Susquehanna River basin: New York State Department of Environmental Conservation, Bull. $71,130 \mathrm{p}$.

Kunz, C. O., 1982, Radioactive gas production and venting at a lowlevel radioactive burial site: Nuclear and Chemical Waste Management, v. 3, p. 185-190.

LaFleur, R. G., 1979, Glacial geology and stratigraphy of Western New York Nuclear Service Center and vicinity, Cattaraugus and Erie Counties, New York: U.S. Geological Survey Open-File 
Report 79-989, $17 \mathrm{p}$.

Lappala, E. G., 1981, Modeling of water and solute transport under variably saturated conditions-state of the art, in Little, C. A., and Stratton, L. E., eds., Modeling and low-level waste management-an interagency workshop: Oak Ridge, Tenn., Oak Ridge National Laboratory, ORO-821, p. 81-137.

LaSala, A. M., Jr., 1967, New approaches to water-resources investigations in upstate New York: Ground Water, v. 5, no. 4, p. 6-11. -1968 , Ground-water resources of the Erie-Niagara basin, New York State Conservation Department Basin Planning Report ENB-3, 114 p.

Lu, A. H., 1978, Modeling of radioactive migration from a low-level radioactive waste-burial site: Health Physics, v. 34, p. 39-44.

Lu, A. H., Matuszek, J. M., 1978, Transport through a trench cover of gaseous tritiated compounds from buried radioactive wastes: International Symposium on the Behavior of Tritium in the Environment: San Francisco, Calif., International Atomic Energy Agency, IAEA-SM-232/60, $22 \mathrm{p}$.

Matuszek, J. M., 1980, Biochemical and chemical processes leading to radionuclide transport from low-level waste burial sites: Transactions America Nuclear Society, v. 24, p. 155-156.

Matuszek, J. M., Strnisa, F. V., and Baxter, C. F., 1976, Radionuclide dynamics and health implications for the New York Nuclear Service Center's radioactive waste-burial site: Vienna, Austria, International Atomic Energy Agency, IAEA-SM-207/59, p. 359-372.

Millington, R. J., and Quirk, J. P., 1961, Permeability of porous solids: Transactions of Faraday Society, v. 57, p. 1200-1207.

Morris, D. A., and Johnson, A. I., 1966, Summary of hydrologic and physical properties of rock and soil materials, as analyzed by the hydrologic laboratory of the U.S Geological Survey, 1948-1960: U.S. Geological Survey Water-Supply Paper 1839-D, $42 \mathrm{p}$.

Muller, E. H., 1977a, Late glacial and early postglacial environments in western New York: Annals of the New York Academy of Sciences, v. 288 , p. 223-233.

-1977b, Quaternary geology of New York, Niagara sheet: New York State Museum and Science Service Map and Chart Series No. 28.

National Oceanic and Atmospheric Administration, 1978, Climate of New York: Asheville, N.C., National Climate Center, Climatography of the United States, no. 60, 28 p.

National Weather Service, 1966-79, Climatological data, New York: Asheville, N.C., National Climate Center (published monthly with annual summary).

Neuman, S. P., 1975, Galerkin method of analyzing unsteady flow in saturated-unsaturated porous media, in Gallager, R. W., Oden, J. J., Taylor, C., and Zienkiewicz, O. C. eds., Finite elements in fluids: London, England, John Wiley and Sons, Inc., v. 1, chapter 10.

Nuclear Fuels Services, Inc., 1962, Safety analysis, spent fuel processing plant: Part B of license application to U.S Atomic Energy Commission, v. 1 [no pagination].

Pettijohn, R. A., 1977, Nature and extent of ground-water-quality changes resulting from solid-waste disposal, Marion County, Indiana: U.S. Geological Survey Water-Resources Investigations $77-40,129 \mathrm{p}$.

Phillips, R. E., and Brown, D. A., 1968, Self-diffusion of tritiated water in montmorillonite and kaolinite clay: Soil Science of America Proceedings, v. 32 , no. 3 , p. $302-306$.

Pinder, G. F., and Frind, E. O., 1972, Application of Galerkin's procedure to aquifer analysis: Water Resources Research, v. 8, no. 1, p. $108-120$.

Prudic, D. E., 1978, Installation of water- and gas-sampling wells in low-level radioactive waste-burial trenches, West Valley, New
York: U.S. Geological Survey Open-File Report 78-718, 70 p. $-1979 a$, Core sampling beneath low-level radioactive wasteburial trenches, West Valley, Cattaraugus County, New York: U.S. Geological Survey Open-File Report 79-1532, 55 p.

$1979 \mathrm{~b}$, Recharge to low-level radioactive waste-burial trenches 11 through 14, West Valley, New York: U.S. Geological Survey Open-File Report 79-990, 5 p.

1980 , Permeability of covers over low-level radioactive-waste burial trenches: U.S. Geological Survey Water-Resources Investigations $80-55,30 \mathrm{p}$.

1981, Computer simulation of ground-water flow at a commerical radioactive-waste landfill near West Valley, Cattaraugus County, New York, in Little, C. A., and Stratton, L. E., eds., Modeling and low-level waste management-an interagency workshop: Oak Ridge, Tenn., Oak Ridge National Laboratory, ORO-821, p. 215-248.

-1982 , Hydraulic conductivity of a fine-grained till, Cattaraugus County, New York: Ground Water, v. 20, no. 2, p. 194-204.

Prudic, D. E., and Randall, A. D., 1979, Ground-water hydrology and subsurface migration of radioisotopes at a low-level, solid radioactive-waste disposal site, West Valley, New York, in Carter, M. W., Kahn, Bernd, and Moghissi, A. A., eds., Management of low-level radioactive waste: New York, Pergamon Press, v. 2 , p. $853-882$.

Qasim, S. R., and Burchinal, J. C., 1970, Leaching of pollutants from refuse beds: Journal of Sanitary Engineering, Division of American Society of Civil Engineers, v. 96, no. SA1, p. 49-57.

Ragan, V. S., Molello, S. A., Dana, R. H., Jr., Fickies, R. H., and Fakundiny, R. H., 1979, Studies of surface water transport of radionuclides at the low-level radioactive waste-burial site at West Valley, New York, 1976-1977: New York State Geological Survey Open-File Report 79-2410, 77 p.

Randall, A. D., 1980, Glacial stratigraphy in part of Buttermilk Creek Valley, in LaFleur, R. G., ed., Late Wisconsin stratigraphy of the Upper Cattaraugus basin: Guidebook, 43rd annual Reunion, Northeast Friends of the Pleistocene, p. 40-62.

Reeves, Mark, and Duguid, J. O., 1975, Water movement through saturated-unsaturated porous media-a finite-element Galerkin model: Oak Ridge, Tenn., Oak Ridge National Laboratory, ORNL-4927, 232 p.

Remson, Irwin, Hornberger, G. M., and Molz, F. J., 1971, Numerical methods in subsurface hydrology: New York, John Wiley and Sons, Inc., Wiley Interscience Division, 389 p.

Robinson, R. A., and Stokes, R. H., 1955, Electrolyte solutions: New York, Academic Press, 512 p.

Schultz, L. G., 1964, Quantitative interpretation of mineralogical composition from X-ray and chemical data for the Pierre Shale: U.S. Geological Survey Professional Paper 391-C, p. C1-C32.

Seaber, Paul, and Hollyday, E. F., 1964, Hardness of ground water in the glacial deposits of the Susquehanna River basin, New York and Pennsylvania [abs.]: Geological Society of America, Program 1964 Annual Meeting.

Sherwood, T. K., Pigford, R. L., and Wilke, C. R., 1975, Mass transfer: New York, McGraw-Hill, 677 p.

Sun, R. J., and Mongan, C. E., 1974, Hydraulic fracturing in shale at West Valley, New York-a study of bedding-plane fractures induced in shale for waste disposal: U.S. Geological Survey Open-File Report 74-365.

Thatcher, L. L., Janzer, V. J., and Edwards, K. W., 1977, Methods for determination of radioactive substances in water and fluvial sediments: U.S. Geological Survey Techniques of WaterResources Investigations, Book 5, Chapter A5, 95 p.

Thomas, M. P., 1966, Effect of glacial geology upon time distribution of streamflow in eastern and southern Connecticut: U.S. 
Geological Survey Professional Paper 550-B, p. B209-B213.

Wang, J. H., Robinson, C. V., and Edelman, I. S., 1953, Self-diffusion and structure of liquid water, III-measurement of self-diffusion of liquid water with $\mathrm{H}^{2}, \mathrm{H}^{3}$, and $\mathrm{O}^{18}$ as tracers: Journal of the American Chemical Society, v. 75, no. 2, p. 466-470.

Weiss, A. J., and Colombo, Peter, 1980, Evaluation of isotope migration-land burial; water chemistry at commercially operated low-level radioactive waste-disposal sites: Upton, N.Y., Brookhaven National Laboratory, BNL-NUREG-51143, 271 p.

Whitney, P. R., 1977, Chemical and mineralogical investigation of surficial materials from the West Valley Nuclear Waste disposal site: New York State Geological Survey Open-File Report, 15 p. 